S. L. MIBRARY 


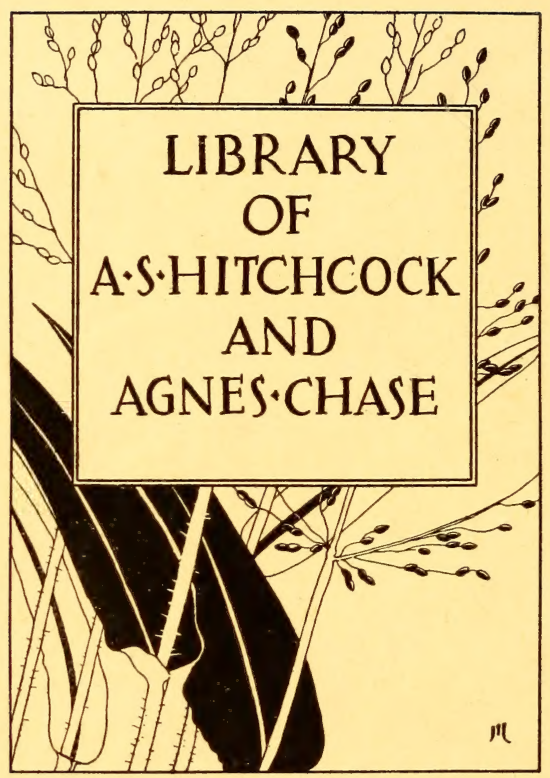





Handbooks of the Flora and Fauna of South Australia, issued by the British Science Guild (South Australian Branch) and published by favor of the Honorable the Premier (Sir Henry Barwell, K.C.M.G.).

\section{FLORA}

oF

\section{SOUTH AUSTRALIA.}

Parì I.

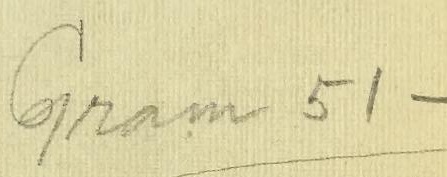

sec Altehrom $1933,1934$.

\section{Cyatheaceae - Orchidaceae.}

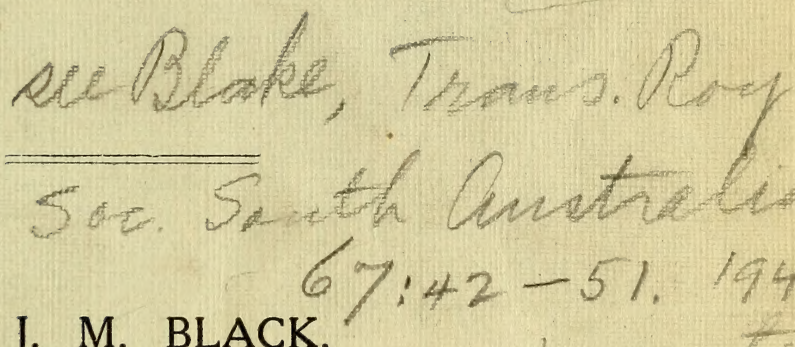

By J. M. BLACK.

(ORCHIDACEAE By Dr. R. S. ROGERS.)

WITH ILLUSTRATIONS.

Price: THREE SHILLINGS.

COPYRIGHT.

ADELAIDE :

Prtited by R. E. E. Rogers, Goveringent Printer, North Terrage. 


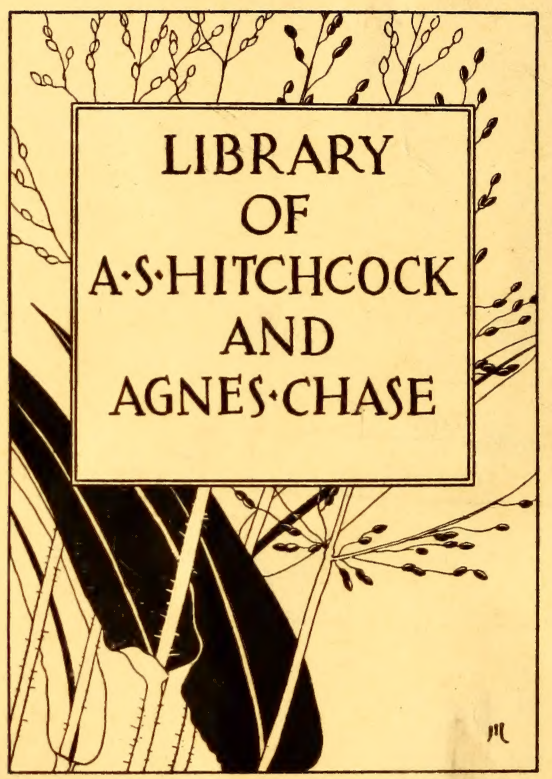


Handbooks of the Flora and Fauna of South Australia, issued by the British Science Guild (South Australian Branch) and published by favor of the Honorable the Premier (Sir Henry Barwell, K.C.M.G.).

\section{FLORA}

$\mathrm{OF}$

\section{SOUTH AUSTRALIA.}

Part I.

\section{Cyatheaceae - Orchidaceae.}

$$
\text { By J. M. BLACK. }
$$

(ORCHIDACEAE By Dr. R. S. ROGERS.)

\section{WITH ILLUSTRATIONS.}

\section{ADELAIDE :}

Printed by R. E. E. Rogers, Government Printer, North Terrace. 


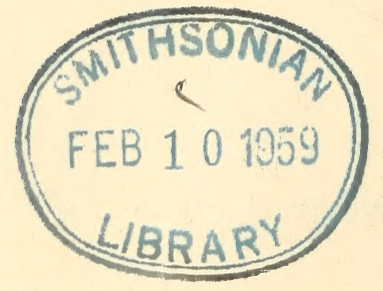




\section{EDITORIAL PREFACE.}

Handbooks of the Flora and Fauna of South Australia, issued by the British Science Guild (South Australian Branch).

Recognising the need for a wider diffusion of accurate knowledge of our Flora and Fauna, the Guild has undertaken the issue of a series of handbooks.

There is an admitted lack of inexpensive but accurate books dealing with the plants and animals of South Australia, and it is felt that the absence of such has been a real handicap to young Australia, and so to the progress of Australian science. These volumes, which have been planned to meet the want, are being prepared gratuitously by South Australian biologists and geologists: they will be printed and published by the State Government, and will be placed in all the public schools, for the use of which they are being primarily written. 



\section{AUTHOR'S PREFACE.}

This descriptive and illustrated handbook of the flora of South Australia has been written to assist students, plant-lovers, or persons engaged in pastoral or agricultural pursuits, who may wish to know something about the native and naturalised plants of the State.

Locality and time of flowering are given after the description of each plant, and, where an alien is in question, the country of origin is added. In those parts of the State which enjoy regular winter rains, the flowering period can be stated with a fair amount of accuracy, but in the dry lands of the Far North and West there is much less regularity. "If rain should fall in summer," writes the Rev. H. Kempe, with reference to the country along the Finke River, just north of our boundary, "then nearly all species of flowering plants, even most of the shrubs, commence to blossom a second time.'

Where the same plant has been found in many different places, the localities are summarised in broad terms. Thus the phrase "Southern districts" implies the country from Encounter Bay northwards to about the latitude of Gladstone and Terowie, and usually includes Yorke Peninsula and Kangaroo Island. "Murray lands" comprise the great low-lying and rather dry area through which the River Murray finds its way to the lakes and the sea, and which is bounded on the west by the slopes of the Mount Lofty Ranges, and stretches northward from the neighborhood of Bordertown towards the railway running from Peterborough to Broken Hill. According to geologists this is part of the ancient estuary into which the Murray and the Darling once flowed separately. The Flinders Range, beginning at Crystal Brook, subsides into the great northern plains near Marree (Hergott Springs) and the northern end of Lake Frome. The dry country to the north of those points, and extending to the borders of Queensland and the Northern Territory, is generalised as the "Far North." This district is especially arid in the Lake Eyre Basin. Westward of Oodnadatta the land rises gradually towards the Everard, Musgrave, and Birksgate Ranges-the "Far North-West." This distant corner of South Australia, accessible only by camel expeditions, has been very imperfectly explored in a botanical sense, and the same is true of the territory to the south of the ranges-the great treeless Nullarbor Plain and the desolate and often sandy country toward Ooldea and Tarcoola, now stations on the East-West Railway. All this vast area slopes gradually southwards to the shores of the Great Bight. . The "South-East"' is the well-watered and often swampy region southward 
from Naracoorte to Beachport and Mount Gambier. In cases where a plant has only been collected once or twice, the precise localities are given.

The system of classification adopted is almost entirely that of Engler and Gilg's 'Syllabus der Pflanzenfamilien,' which is essentially the same as that followed by Engler and Prantl in the "Naturrlichen Pflanzenfamilien.' Th s classification, proceeding from the simpler to the more highly developed forms of plant life, has been utilised by the authors of all the more recent floras, and by Maiden and Betche in their "Census of New South Wales Plants,"' published in 1916.

The comparative characters given in the keys refer only to South Australian species, native or naturalised.

In respect to nomenclature, the rules and recommendations adopted by the International Botanical Congress of Vienna in 1905 have been strictly followed. One of the most important rules provides that the earliest specific name given to a plant must be carried forward if the species is transferred to another genus. For instance: a common shrub in South Australia was originally named Stenochilus glaber by Robert Brown in 1810; it was removed to Eremophila by Mueller in the third volume of the Proceedings of the Royal Society of Tasmania, published in 1858, under the name of E. Brownii. As this neglect to preserve Brown's specific name constitutes a breach of the rules of nomenclature, the name was altered to E. glabra by C. H. Ostenfeld, in the third part of his "Contributions to West Australian Botany," published in 1921, and now stands as Eremophila glabra, (R. Br.) Ostenf.

The same rule of priority of publication was applied to the names of genera, but here a modification was introduced, by which, in order to prevent confusion resulting from too many changes, certain generic names which have been in general use for a great number of years are to be retained, even though they are not the earliest. A list of "names to be retained" ("nomina conservanda") is appended to the rules of the Congress, but it must be allowed that it is drawn up in a somewhat arbitrary manner. Thus the generic names Hypolaena and Patersonia, established by Brown in 1810, are retained in preference to Calorophus and Genosiris, published by Labillardière in 1806 and 1804 respectively, but no reference is made to Brown's Xerotes and Angianthus (1810), which have therefore to give way to Labillardière's Lomandra (1804) and Siloxerus (1806). However, it is only by adhering closely to the international rules and recommendations that we can ever hope to attain uniformity in nomenclature.

Recommendation 11 states that specific names commemorating men, when ending in a consonant and used in the genitive case, are to be formed by adding the letters -ii, except when the name ends in -er, and 
then the termination becomes -eri. This recommendation has been followed throughout the present work. Botanical names place a considerable strain on the memory in any case, and to ask the user of them to remember that Bentham named one plant Abutilon Mitchelli and another Goodenia Mitchellii, although both specific names commemorate the same man (Sir Thomas Mitchell), is to ask too much. Then we find Hibbertia Billardierii, F. v. M. (altered by Bentham to H. Billardieri) and Brachycome Billardieri, Benth.; Viola Cunninghamii, Hook. f. and Senecio Cunninghami, DC. (altered by Bentham to S. Cunninghamii) ; Acacia Bidwilli, Benth., and Helichrysum Bidwillii, Benth. Many other similar irregularities could be cited, and the need of some uniform practice must be evident to all.

A cautious attitude has been adopted with respect to naturalised aliens. These were not described at all in Mueller's "Key to the System of Victorian Plants" (1887-88), Tate's "Flora of ExtraTropical South Australia', (1890), or Moore and Betche's "Handbook of the Flora of New South Wales', (1893). This is contrary to the practice of botanists in all other countries, where naturalised plants, that is to say, alien plants growing wild and propagating themselves spontaneously, are included in the flora without any distinguishing sign. In this book only well-established aliens are described, and they are preceded by an asterisk. The descriptions are brief, and those who desire further information on these and also on many other introduced plants which have only been found in a few localities, are referred to my illustrated "Naturalised Flora of South Australia.", In a few instances, such as Cynodon dactylon and Juncus bufonius, there is some doubt as to the category in which the plants should be placed-native or foreign-but to omit all our common aliens would be to hamper the progress of the student and the plant-lover, especially if he begins his investigations near a town. In that case the first plant which he gathers will most probably be an immigrant.

Our native plants have been to a considerable extent exterminated in the settled districts, except along the roads and railway reserves, or in stony, scrubby, or hilly country. The plough, the grazing of stock, the hardening of the soil in winter by the hoofs of large cattle, and the attacks of rabbits, who in time of drought eat even the bark of shrubs, are the chief causes of this destruction. The invasion of introduced plants is also effecting a great change in our flora. The smaller plants of Australia, isolated for thousands of years and unaccustomed to the battle of life with foreign plants and large animals, lack the viability of the flora of other lands. The trees are an exception, although seedlings are in many cases destroyed by stock. Near towns the alien grasses, clovers, medics, and various lowly plants and weeds from abroad occupy most of the ground. 
Professor T. G. B. Osborn has permitted the use of the Tate and Menzel-Cleland herbaria, which are stored in the University of Adelaide; and Mr. J. F. Bailey has allowed me to consult the Schomburgk herbarium in the museum of the Botanic Gardens. These, together with my own collection, are the principal materials examined for the production of the present work.

The botanical drawings are by the author, with the exception of those illustrating the Orchids, which are the work of Miss R. C. Fiveash.

82, Brougham Place, North Adelaide.

J. M. BLACK. 


\section{HISTORY OF BOTANY IN SOUTH AUSTRALIA.*}

Botanical research in South Australia begins with the arrival of Robert Brown as botanist to Flinders' voyage of discovery in the Investigator. His first landing in this State was at Fowler's Bay on January 29, 1802. He also botanised at various islands on the West Coast, and reached Port Lincoln on February 24. Mount Brown, near Port Augusta, was ascended and named after him. The eastern end of Kangaroo Island was explored on two visits in March and April. Speaking of Robert Brown in the preface to the "Flora Australiensis," Bentham says: "He seems during his short visits often almost to have exhausted the flora of the points he touched at.' Brown, who was 28 years old when he landed at Fowler's Bay, was accompanied on the Investigator by Ferdinand Bauer, a young Austrian botanist, who had joined the expedition as "natural history draughtsman.' 'The results of Brown's collections along almost the whole coast of Australia were published by him in the "Prodromus Florae Novae Hollandige," London, 1810. This work laid the foundation of Australian systematic botany and also of that worldwide reputation which its author subsequently attained. He died in London in 1858.

At the same time that Flinders was sailing eastwards, a French scientific expedition under Baudin was approaching from the west, and the ships met in Encounter Bay on April 8, 1802. The botanist of the French expedition was Leschenault de la Tour, and he also collected on Kangaroo Island, at Port Lincoln, and at Nuyts Archipelago during 1803, but on his return to Paris he did not describe his Australian specimens. A few of them were subsequently dealt with by other French botanists. The earlier French expedition in search of La Pérouse, under the command of D'Entrecasteaux (1791-94), did not touch at any point on the shores of South Australia. The talented botanist of that expedition, Jacques-Julien Labillardière, described and figured several South Australian species in his "Novae Hollandiae plantarum specimen"' (2 vol., Paris, 1804 and 1806), although the actual types were gathered in West Australia and Tasmania.

After these early maritime expeditions, botanical research in South Australia was not resumed, with one exception, until after the foundation of the province in 1836. The exception was a passing visit paid to Kangaroo Island in 1823 by William Baxter, a gardener sent out by an English firm to collect seeds and roots. The illustration of Correa pulchella in Sweet's. "Flora australasica" (1827-28) is from a plant raised from seed collected by Baxter on Kangaroo Island.

Captain Charles Sturt left Adelaide in 1844 to explore the interior of the continent. He discovered and crossed Cooper Creek, passed the Stony Desert which will always be associated with his name, and penetrated some distance into southern Queensland. A great drought prevailed, and he returned to Adelaide in 1846, almost blind through the trials he had undergone. Nevertheless, he made a botanical collection, which was described by Robert Brown in an appendix to the "Narrative of an Expedition into Central Australia," London, 1849 .

* See also a paper entitled "A Century of Botanical Endeavor in South Aus. tralia," read by J. H. Maiden, F.L.S., at the meeting of the Australasian Association for the Advancement of Science in 1907. It contains a wealth of information, and I am much indebted to it. 
In December, 1847, a young man, who was destined to become the most distinguished of Australian botanists, landed at Port Adelaide. This was Dr. Ferdinand Mueller, who was born at Rostock in 1825, and had taken his degree as doctor of philosophy at the University of Kiel in 1847. He obtained employment in a chemist's shop in Rundle Street, but found time to make botanical excursions in the Mount Lofty Ranges, at Guichen Bay, in the Murray scrub, and as far north as Mounts Brown and Arden. In 1852 he was appointed, through the influence of Sir William Hooker, to the position of Government Botanist of Victoria. Then commenced that long career of exploration, collection, and study of Australian plants which gave him a pre-eminent place in the world of science. His descriptions of numerous new species, records of fresh localities, and critical observations on Australian systematic botany are for the most part contained in the "Fragmenta phytographiae Australiae," published in 11 volumes and part of a 12th, Melbourne, 1858-82. Not less important are his illustrated works on the Eucalypts, the Acacias, and the Salsolaceous and Myoporaceous plants of Australia. In 1871 the King of Wurtemberg created him a baron, and in 1879 he was knighted by Queen Victoria, and became Baron Sir Ferdinand von Mueller, K.C.M.G. He died in 1896.

In 1858 B. Herschel Babbage was dispatched by the South Australian Government to explore the country between Lake Torrens and Lake Gairdner, and he took with him a young Bavarian named David Hergolt as botanical collector. His numerous specimens were determined by Mueller in a report published at Melbourne in 1859. The genus Babbagia was named after the leader of the expedition. Hergolt was commemorated by J. McDouall Stuart in April, 1859, as the discoverer of Herrgott or Hergott Springs (the name, as printed in Stuart's "Journals," is already corrupted into both these forms). Hergolt died in Melbourne in 1861.

It was also in 1858 that A. C. Gregory, leader of the Barcoo expedition in search of Leichhardt, arrived at Cooper Creek, in South Australian territory. His plants were recorded by Mueller in a report published in 1859 .

At about the same time (between May, 1858, and January, 1860) John McDouall Stuart made various excursions into the country westward of Lakes Torrens and Eyre, and southward to Denial and Streaky Bays, before undertaking his great transcontinental journeys, 1860 to 1862 . His plants were catalogued by Mueller in the fourth volume of the Transactions of the Philosophical Institute of Victoria (1860), without localities, and in an appendix to the "Journals of J. McDouall Stuart' (1864), but very few species appear to have been collected in South Australia.

The final tragedy of the Burke and Wills expedition (1860-61) took place on the banks of Cooper Creek, in South Australian territory, but no collecting was done in this State, as Dr. Hermann Beckler, the botanist and medical officer, did not advance further than the Bulloo camp, in south-western Queensland. Some new species were discovered by Beckler in New South Wales, near the Barrier Range, and for the most part these also inhabit South Australia. They were described by Mueller.

A. W. Howitt, who led the relief expedition, was on Cooper Creek in September, 1861, and February, 1862. Botanical specimens, 
collected on this journey by Dr. Wheeler and Dr. J. Murray, were recorded by Mueller in vol. 3 of the "Fragmenta."

"Wild Flowers of South Australia," by Miss F. E. De Mole, with 20 colored plates, was published at Adelaide in 1861. This work is probably very rare; the Adelaide Public Library possesses a copy.

Dr. Richard S.shomburgk, director of the Adelaide Botanic Gardens, wrote a "Flora of South Australia", in 1875, to accompany Harcus's "South Australia." It consists of an introductory essay, followed by a list of species, without descriptions, and compiled from the "Flora Australiensis."

Ernest Giles led an expedition westward in 1875, through Ooldea (orginally written "Youldeh') and Ouldabinna, across the West Australian border and the Great Victoria Desert. W. H. Tietkens and J. Young collected plants on this journey. In the following year Giles returned, starting from the Ashburton River, keeping a northerly route through the desert, and entering South Australia again near the Musgrave Range. The important botanical results were dealt with by Mueller in the Journal of Botany, vol. 15 (1877).

The first volume of the "Flora Australiensis" was published in London in 1863. This great undertaking, "published under the authority of the several Governments of the Australian colonies,' was entrusted to George Bentham. He and Sir Joseph Hooker (his collaborator in that other gigantic work, the "Genera plantarum"), were the two most illustrious English botanists of the day. Besides the copious material supplied from Australia by Mueller and others, Bentham had at his disposal the vast accumulation of Australian plants preserved in London and other European cities since the days when the first collections were brought home by Sir Joseph Banks and Dr. Solander in 1771. It was fortunate that so great a task was confided to so great a botanist. After 15 years of unremitting labor the seventh and last volume was issued in 1878 . No less than 1,400 genera and 8,168 species were described with a clearness and thoroughness for which all subsequent students have reason to be grateful. Bentham, who was born in 1800, died in 1884 .

Charles Winnecke explored the Stuart Range in 1885, and a list of his plants was published by Mueller in the Transactions of the Royal Society of S.A., vol. 8 (1886).

The Elder scientific exploring expedition of 1891-92 collected largely in South and West Australia. David Lindsay was the leader and $\mathrm{R}$. Helms the botanical collector. Starting from Warrina on May 2, 1891, the party ascended the Arkaringa Creek, visited the Everard, Musgrave, Birksgate, and Tomkinson Ranges, and crossed the border into West Australia about the end of July. The flowering plants and ferns were recorded by Mueller and Tate in Trans. Roy. Soc., S.A., part 3 of vol. 16 (1896). Duplicates of this fine collection are preserved in the Tate Herbarium. Helms was born at Altona in 1842 and died in New South Wales in 1914.

Ralph Tate arrived in 1875 as the first professor of natural history in the University of Adelaide. His work covered zoology in all its branches, botany, and geology. The numerous botanical papers which he read before the Royal Society of South Australia testify to his keen interest in that science, which he advanced, not only by his studies in the cabinet, but by his activity in the field as a collector. There are few parts of South Australia which he did not visit, and 
in 1894 he accompanied the Horn scientific expedition to Central Australia, exploring the Finke River and the MacDonnell Ranges. The comprehensive botanical report is from his pen. Previous to this expedition, Professor Tate published "A Handbook of the Flora of Extra-Tropical South Australia,' Adelaide, 1890. For the first time a description of the flowering plants and ferns of our State was made available to students of botany in a handy, although severely condensed form. Professor Tate, who was born at Alnwick, Northumberland, in 1840, died in Adelaide in 1901.

Dr. Hermann Behr was a diligent collector, chiefly in the neighbourhood of Gawler, about the middle of last century. He described, in conjunction with Schlechtendal, one of our best known trees, the Peppermint gum (Eucalyptus odorata). F. G. Waterhouse, curator of the South Australian Museum, botanised on Kangaroo Island in 1861. E. G. Sealey and H. Heuzenroeder also gathered plants on that island between 1849 and 1851. Carl Wilhelmi collected near Port Lincoln in the early fifties, and Dr. W. Hillebrand and Blandowsky near Adelaide about the same period. The Rev. J. E. Tenison-Woods studied our flora near Penola in the sixties and seventies. S. Dixon devoted special attention to our native fodder plants, and Max Koch collected largely on Mount Lyndhurst run, in the Flinders Range. J. G. O. Tepper contributed several botanical papers to the Proceedings of the Royal Society as the result of his investigations at Ardrossan, Clarendon, Kangaroo Island, and elsewhere.

John Ednie Brown, Conservator of Forests from 1879 to 1890 , produced "The Forest Flora of South Australia." It consists of beautifully colored plates of very large size, accompanied by descriptive letterpress. Begun in 1882, it did not extend beyond nine parts, of which each contains five plates.

Dr. R. S. Rogers, the leading authority on Australian orchids, describes the Orchidaceae in the present work.

During recent years valuable botanical collections were made by Captain S. A. White on three expeditions in the dry North: the first, from Oodnadatta to the River Finke and the MacDonnell Ranges, in 1913, principally in what is now federal territory; the second, from Oodnadatta to the Everard and Musgrave Ranges, in 1914; the third, to Strzelecki and Cooper Creeks, in 1916. Several other recent collectors have also done much to extend the knowledge of our local flora, among whom may be mentioned Professor J. B. Cleland, H. Griffith, E. H. Ising, and H. W. Andrew.

J. H. Maiden, Government Botanist of New South Wales, visited this State in 1907, and published in the following year "A Contribution to the Botany of South Australia" (Trans. Roy. Soc. S.A., vol. 32), treating chiefly of collections made on Kangaroo Island and the West Coast. Mr. Maiden has dealt specially with our Acacias and Eucalypts in the paper mentioned, and also in others published in Sydney, notably (as regards the Eucalypts) in his "Critical Revision of the genus Eucalyptus," a monumental work, which is still in course of publication. Our local Eucalypts and their essential oils were the subject of a paper contributed in 1916 by R. T. Baker and H. G. Smith, of the Technological Museum of Sydney (Trans. Roy. Soc. S.A., vol. 40).

Professor Osborn, of the Adelaide University, has written on our plants and plant ecology in the Transactions of the Royal Society of South Australia and in the Annals of Botany. 


\section{GLOSSARY OF BOTANICAL TERMS.}

Abortive, imperfectly developed.

Accrescent, growing larger after flowering, as the sepals.

Achene, a dry indehiscent 1-seeded fruit.

Actinomorphic, see regular.

Acuminate, tapering suddenly into a point.

Acute, sharp, gradually pointed.

Adnate, see connate.

Adventitious, any organ produced in an abnormal position.

Albumen, material stored within the seeds of many plants for the nourishment of the embryo; it lies between the seedcoats and the embryo sac (perisperm), or within the embryo sac (endosperm).

Alternate, (1) leaves or flowers inserted at different heights along the branches; (2) intervening between: as stamens which are alternate with the petals.

Amphitropous, when the ovule is laterally attached to the funicle, so that the chalaza and micropyle are at opposite ends of the ovule.

Anastomosing, applied to the small nerves or veins of a leaf when they are connected like the meshes of a net (reticulate).

Anatropous (inverted), when an ovule is bent back along its funicle, so that the micropyle stands at the apparent base of the ovule and the chalaza at the opposite end (the apparent summit). Owing to the presence of the rhaphe the hilum of the seed does not coincide with the chalaza, but lies close to the micropyle. This is the commonest form of ovule (fig. 2).

Androecium, a collective name for the stamens.

Androgynons, when male and female flowers are mixed in a spike or head.

Angiosperms, plants having seeds enclosed in a seedvessel.

Annaal, a plant flowering and dying in one year.

Annular, ring-shaped.

Anterior, the parts of a flower furthest from the axis of the branch or stem on which it grows.

Anther, see stamen.

Apiculate, ending abruptly in a short point.

Apocarpous, a pistil or gynoecium consisting of one earpel, or of several earpels all free and distinct (Ranunculaceae, Dilleniaceae).

Appressed, pressed closely against another organ, as leaves against a stem.

Approximate, growing near together.

Aril (arillus), an expansion of the funicle into a membranous or fleshy appendage, sometimes covering a considerable part of the seed.

Article, part of an organ which separates easily from the rest of the organ at a point called the articulation or joint.

Articulate, jointed.

Ascending, spreading horizontally and then becoming erect.

Auricle, ear-shaped lobe at the base of a leaf or other organ.

$A w n$, a fine bristle terminating an organ or inserted on its back.

Axil, the angle formed by the leaf and the branch.

Axile-Placentas are axile when they and the ovules are attached to the inner angle (inner suture) of the earpels of a compound ovary (fig. 1).

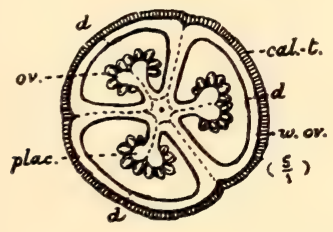

FIG. 1.-Transverse section of ovary of Wahlenbergia gracilis : $c a l .-t$, , adherent receptacle (formerly described as the "calyx-tube"); $w$. $o v$, wall of ovary; plac., axile placentas, intruding into each of the three united carpels of the ovary ; $d$, place of loculicidal dehiscence of the ripe capsule; ov., ovules.

Axillary, arising from the axil of a leaf or a bract.

Axis, line passing through the centre of a body: the stem, the rhachis and branches of a panicle, the rhachilla of grasses, are all axes.

Barb, one of the lateral or radial hairs of a plumose bristle.

Barbellate, furnished with short, sometimes microscopic barbs, too small for the bristle to be called plumose.

Basifixed, an anther attached by its base to the filament.

Berry, a juicy fruit with the seeds immersed in the pulp. 
Biennial, a plant which flowers and dies in the second year.

Bifid, eut in two for about half its length.

Bipinnate, a leaf whose primary divisions (leaflets) are again pinnate.

Bipinnatifid, a leaf whose primary lobes are again pinnatifid.

Bipinnatisect, twice pinnatisect.

Bisexual, a flower with the reproductive organs of both sexes.

Bract, a small leaf at the base of the peduncles or pedicels, and differing from the other leaves in size or shape. Bracts may also oceur on peduncles, seapes, or flowering branches without any pedicels in their axils.

Bracteate, furnished with bracts.

Bracteole, a small bract on the pedicel or even on the calyx. Bracteoles are usually two, and placed opposite each other.

$B$ Bulb, a short thick rootstock in which the bud or buds are covered by leaf-scales.

Bulbil, a minute bulb.

Caducous, falling off very early.

Callus, (1) a hard protuberance on some petals, such as the standard of Swainsona nd the labellum of some orchids; (2) a hardened decurrent extension of the flowering glume along the rhachilla in some grasses, such as Stipa; this callus and the adnate article of the rhachilla fall off with the fruiting glume in the form of a short obeonical stipes.

Calyx, outer envelope of the flower, consisting of free or united sepals.

Campanulate, bell-shaped.

Campy'otropous, when an ovule is curved so that the micropyle and chalaza come near each other.

Capi'lary, hair-like, very slender.

Capitate, (1) shaped like a head (stigma, \&e.); (2) growing in a head-like cluster (flowers of Compositae).

Capsule, a dry fruit (consisting of two or more united carpels), usually splitting into pieces called valves when ripe, or opening at the summit by teeth or pores.

Carpel, a fruit-leaf folded lengthwise and united by its edges; the lower and swollen portion forms the ovary, inside which the ovules are produced; the upper and narrower portion forms the style and stigma (fig. 2).

Carpophore (gynophore), stalklet or axis arising from the receptacle and supporting certain fruits.

Cartilaginous, gristly.

Caruncle, a fleshy appendage of the seed, growing near the funicle.

Caudicle, a straplike structure connecting the pollen-masses in Orchids to the viseid disk of the rostellum.

Cauline, inserted on the stem.

Cell, (1) the cavity of the ovary, and especially each cavity of a compound ovary or compound fruit; (2) a pouch or pollen-sac of the anther; (3) one of the minute masses of protoplasm which go to make up the tissue of plants.

Centrifugal or definite, applied to that kind of inflorescence, such as the cyme, where the terminal flower opens first and then those on the lateral branches.

Centripetal or indefinite, that kind of inflorescence, such as the head, spike, raceme, or panicle, where the outermost or lowest flowers open first and the main rhachis continues to lengthen, developing fresh flowers.

Chalaza, see ovule.

Ciliate, bordered by hairs like eye-lashes (cilia).

Ciliolate, bordered by very short hairs.

Circumsciss, when a capsule opens by a transverse line, so that the upper part comes off like a lid.

Clavate, elub-shaped.

Claw, the narrow lower part of a petal or involucral bract.

Clinandrium, the depression on the top of the column in Orchids, on which the anther rests.

Collateral, placed side by side.

Column, the combination of stamens and style in a solid body, as in Orchids and Stylidiaceae.

Complicate (conduplicate), folded flat together.

Compound, composed of several parts, as a leaf consisting of several leaflets, or a pistil consisting of several carpels; the opposite of simple.

Compressed, flattened lengthwise, either from side to side (laterally), or from front to back (donsally).

Cone, a fruit usually woody, ovoid or globular, consisting of scales arranged around an axis and sheltering the naked seeds. 
Connate, when organs are so closely united that they cannot be separated without tearing. Each of the connate parts is said to be adnate to the other.

Connective, the part of an anther which connects the two cells.

Connivent (or converging), organs approaching one another at the summit.

Cordate, heart-shaped, with the notch below.

Coriaceous, leathery.

Corm, a solid tuberous bulblike rootstock, in which the buds are not covered by scales, or by very thin ones.

Corolla, inner envelope of the flower, consisting of free or united petals.

Corona, a small crown of free or united appendages inserted inside the corolla.

Corymb, inflorescence where the branches start from different points, but reach about the same height.

Cotyledon, see embryo.

Crenate, bordered by blunt or rounded teeth.

Crenulate, erenate with very small teeth.

Crustaceous, hard, thin, and brittle.

Cuneate, wedge-shaped.

Cyme, an inflorescence branched like a panicle, but in which the branches are usually opposite, and the central flower opens first.

Deciduous, falling off finally.

Decurrent, when the blade of the leaf is prolonged downwards along the stem in raised lines or narrow wings.

Decussate, opposite leaves crossing each other in pairs at right angles.

Deflexed (decurved), bent downwards.

Dehiscent (dehiscing), opening when ripe, as a seed vessel or anther.

Dentate, toothed.

Denticulate, finely toothed.

Depressed, flattened from above downwards.

Dichotomous, forked once or several times.

Diffuse, spreading horizontally and loosely branched.

Digitate, a compound leaf whose leaflets spread from a common centre, like the fingers of a hand.

Dioecious, plant whose male and female flowers grow on different individuals.

Disk, (1) an extension of the receptacle between the calyx and pistil. It may be conspicuous in the form of a ring or cushion, or reduced to separate glands or scales. (2) All the central or disk-flowers in a radiate flowerhead.

Dissepiment (septum), one or more vertical partitions dividing the ovary and fruit into two or more cells.

Distat, applied to the free end of the labellum of an orehid, as opposed to the proximal or attached end.

Distichous, regularly arranged in two opposite rows.

Distinct, separate, free.

Divaricate, spreading in different directions from a common centre almost at a right angle.

Divergent, spreading in different directions with a more upright tendency.

Dorsal, relating to the back.

Dorsifixed, ar anther attached by its back to the filament.

Drupe, a fruit in which the pericarp consists of 3 layers: (1) the epicarp or skin, (2) the mesocarp or juicy layer, (3) the bony endocarp or stone; within the endocarp lies the seed or kernel. The peach and olive, and (among Australian plants) the fruit of Nitraria Schoberi are familiar examples.

Emarginate, notched at the summit.

Embryo, the young plant while still enclosed in the seed, consisting of the radicle, or base of the future root, 1 or more coty'edons, or future seedleaves, and the plumule, or future bud. The radicle always points towards the micropyle.

Embryo-sac, see ovule.

Endemic, peculiar to a country or district and not native elsewhere.

Endocarp, the innermost layer of the pericarp.

Endopleura, the inner seed-coat, sometimes called the tegmen.

Entire, when the margin of an organ (such as a leaf), is neither toothed, lobed, or divided.

Epicarp, see pericarp.

Epigynous, when the sepals, petals, and stamens are inserted upon the ovary and the adnate receptacle.

Epiphyte, one plant growing upon another, without deriving nourishment from it. 
${ }_{2}$ Equitant, when a leaf is folded lengthwise and the edges adhere except at the base, where it clasps another leaf on the opposite side of the stem.

Exalbuminous, without albumen.

Exserted, projecting beyond, as the stamens beyond the corolla.

Falcate, curved like the blade of a seythe.

Family, a group of genera which resemble each other.

Fertile, producing seeds; applied also to a seed which is able to germinate.

Filament, see stamen.

Filiform, threadlike, slender.

Floral leaves or leafy bracts, the upper leaves at the base of the flowering branches.

Follicle, a fruit consisting of a single carpel opening only along the inner suture.

Free, not united with any other organ.

Free central placenta, one in the form of a central column rising from the base of the ovary, or consisting of a prolongation of the receptacle, and in both eases unconnected with the walls of the ovary.-Primulaceae, Caryophyllaceae, Santalaceae.

Fruit, the enlarged ovary and whatever other parts of the flower may adhere to it at the time the seed is ripe.

Funicle, a little cord by which the ovule is attached to the placenta.

Fusiform, spindle-shaped, tapering gradually at each end.

Galeate, helmet-shaped.

Geniculate, knee'd, bent like a knee.

Genus (pl. genera), a group of species which resemble each other.

Gibbous, when an organ is swollen at the base or at any other part.

Glabrous, devoid of hairs.

Gland, a wart-like excrescence on or near the surface of an organ and usually secreting a fluid.

Glandular hairs, hairs tipped with a gland.

Glaucous, bluish-green, usually of a pale tint.

Globular, rounded like a globe or sphere (=globose).

G'ume, bract enclosing the flower of grasses and reeds.

Glutinous, sticky.

Grain, the fruit of grasses, also called caryopsis.

Granular, covered with small rounded protuberances.

Gymnosperms, plants, such as pines, whose seeds are naked, i.e., not contained in a seed-vessel.

Gynoecium, see pistil.

Gynophore, stalk supporting an ovary.

Gynostemium, a column formed by the union of style and stamens.

Habit, the general external appearance of a plant.

Hastate, shaped like a halbert, with two spreading somewhat triangular lobes at the base.

Herb, a plant which does not develop a woody stem.

Herbaceous, green and more or less succulent.

Heterogamous, when a flowerhead has the outer flowers female or neuter, and the inner ones bisexual or male.

Hilum, the scar left on the seed where it separates from the funicle.

Hoary, densely covered by almost microscopic hairs, which give the surface a whitish or greyish hue.

Homogamous, when a flowerhead has all the flowers bisexual.

Hyaline, delicately membranous and transparent.

Hypogynous, inserted below the ovary.

Imbricate, overlapping like tiles.

Incised, deeply and unequally cut into lobes or teeth.

Included, enclosed, as stamens within the corolla.

Indehiscent, a fruit which does not split open in a definite manner when ripe.

Induplicate, when the edges of petals or sepals are folded inwards in bud, but without overlapping.

Indusium, (1) membrane covering the spore-cases of some ferns; (2) a cup enclosing the stigma in Goodeniaceae.

Inferior.-An ovary is inferior when it is united with the cupshaped or tubular receptacle; the calyx, petals, and stamens are then all supierior to the ovary, or epigynous. An inferior radicle points towards the base of the fruit; an inferior (apotropous) micropyle points towards the base of the ovary.

Infiorescence, arrangement of the flowers on a plant.

Internode, the part of the stem between two nodes. 
Interpetiolar, stipules placed between the petioles of opposite leaves.

Interrupted, having bare spaces between the parts.

Involucel, (1) the involucre of a partial umbel; (2) the outer calyx in Dipasaceae.

Involucre, a number of bracts surrounding the base of a flowerhead or of an umbel.

Involute (inrolled), with the edges rolled inward, as in the leaves of many grasses.

Irregular.-This term is used in its strictest sense to describe those rare asymmetric flowers which cannot be divided into two equal halves through any vertical plane (such as the Va'erianaceae). It is here applied in a more general sense to a flower in which the parts of either the calyx or corolla are dissimilar in size or shape. It therefore includes flowers which are altogether asymmetric and those which are zygomorphic, or bilaterally symmetrical, i.e., which ean be cut through only one vertical plane into two equal and similar halves (Peaflowers, Pelargonium, Violet, \&c.).

Joint, see article.

Keel, (1) a projecting ridge along the middle of a flat or convex surface; the two partially united lowest petals of pea-shaped flowers.

Kernel, see drupe.

Labellum, (1) the lowest petal of orchids, usually different in form from the two lateral ones; (2) the lowest petal of Stylidiaceae.

Labiate, lipped; where the limb of a corolla is divided into two parts, called an upper and lower lip.

Lacerate, jagged.

Lamina, the blade of a leaf, or the expanded upper part of a petal, sepal, or bract.

Lanccolate, shaped like the head of a lance, tapering at both ends.

Leaflet, each dirision of a compound leaf.

Ligulate, having the limb of the corolla strap-shaped, as in many Compositae.

Ligule, (1) a snall membranous appendage at the summit of the sheath of grassleaves; (2) the one-sided limb of the corolla in many Compusitae.

Limb, the upper lobed and usually spreading part of a ealyx or corolla; it is an expansion upwards of the tube or united part of the ealyx or corolla.

Linear, long and narrow, with parallel edges.

Lobe, division of a leaf reaching about half-way to the midrib, or of some other organ which is only divided for about half its length.

Lobed, (1) eut about half-way; (2) a compound ovary or fruit which is deeply grooved between the carpels.

Locu icidal, when a ripe capsule splits open along the back of its cells (i.e., along: the dorsal suture or midrib of the carpels), as in Juncaceae and most Litiaceae.

Lunate, crescent-shaped.

Lyrate, a pinnatifid or pinnatis ct ieaf with a terminal lobe much larger than the lateral ones.

Mealy (farinose), covered with a scurfy powder like flour.

Membranous, thin, transparent and flexible, not green.

Mesocarp, the second or middle layer of the pericarp; it is often succulent and is then sometimes called the sarcocarp.

Micropyle, a minute opening in the coats of the ovule. In the great majority of plants the pollen-grain finds its way to the embryo-sac through the micropyle.

Midrib, the central nerve of a leaf.

Monitiform, when a pod or other organ is constricted at regular intervals, so as to resemble a necklace of beads.

Monoecious, a plant which has the male and female flowers on the same individual.

Mucronate, terminating abruptly in a short stiff point called a mucro.

Muricate, covered with short hard points.

Naked, flower without any perianth; seed without a pericarp.

Nerveis (veins), the vascular bundles which start from the petiole and traverse the blade of the leaf, the smaller ones often forming a network.

Node, the swollen part of the stem from which leaves or branches spring.

Nut.-Properly a 1-seeded indehiscent fruit, such as the hazel-nut, with a hard dry pericarp ("shell"), but also used to describe any hard 1-seeded nutlike fruit, such as those of Polygonaceae and Cyperaceae.

obcordate, inversely heart-shaped, broad, and rather deeply notched at the summit.

Oblanceolate, lanceolate with the narrow end at the base of the leaf.

oblique, slanting; (of a leaf) unequal-sided. 
Oblong, much longer than broad, and rounded at both ends.

Obovate, ovate with the broadest part above the middle.

Obtuse, blunt.

Opposite, two leaves or other organs rising from the same level on opposite sides of the stem.

orbicular, flat, circular or almost so.

Order, a group of families resembling each other.

Orthotropous (atropous), when an ovule has a straight axis, the chalaza being at its base and the micropyle at the opposite end.

Ovary, the lower part of the carpel or pistil, containing the ovules, and finally becoming the fruit (fig. 2). Compound ovary, see syncarpous.

Ovate, when a flat surface, such as that of a leaf, is egg-shaped and broader below the middle.

Ovoid, egg-shaped (of solid ergans such as fruits).

Ovule, the seed in its early stage. It consists of the embryo-sac, containing the future embryo, completely surrounded by the nucellus, which is in its turn surrounded (except at the micropyle) by an outer covering, usually consisting of two coats, an inner and an outer. At the base of the ovule is a spot called the chalaza, where nourishment enters from the placenta through the funicle, and at the opposite extremity is the small opening through the outer covering, which is called the micropyle (fig. 2).

Palea, the upper of two bracts enclosing the flower of grasses.

Palmatifid, leaf divided into diverging lobes, and so resembling the open hand.

Palmatisect, palmately divided nearly to the base.

Panicle, an inflorescence where the axis is divided into branches bearing several flowers.

Paniculate (panicled), arranged in a panicle.

Papilionate, pea-shaped (flower).

Papillose, covered with minute protuberances called papillae.

Pappus, a ring of hairs or scales which represents the calyx in many Compositae.

Parasite, a plant growing upon another, and deriving its nourishment from the latter.

Parictal placenta, when the placentas and ovules are attached to the walls of a 1-celled compound ovary.

Parted (partite), an organ divided into parts almost to its base.

Pedicel, stalklet of a flower, when the peduncle bears 2 or more pedicellate flowers.

Pedicellate, growing on a pedicel.

Peduncle, stalk of a solitary flower, or common stalk (floral axis or rhachis) of several pedicellate or sessile flowers.

Pedunculate, growing on a peduncle.

Peltate, leaf whose stalk is attached to its under-surface, instead of to the edge.

Pendu'ous ovule, one hanging from the summit of the ovary. The term suspended is sometimes used when the ovule is attached slightly below the summit.

Penicillate, arranged like a tuft of hairs.

Perennial, living for several years.

Perianth, the floral envelope, usually consisting of 2 whorls, the calyx and corolla. The term is specially employed to describe flowers in which the segments of the perianth are much alike but in whorls (as in Liliaceae and Juncaceae), or quite similar and in a single whorl (as in Chenopodiaceae).

Pericarp, the walls of the fruit, consisting of the ripened ovary. The walls or layers may be more or less fused into one, or they may be easily distinguishable as three: the epicarp, mesocarp, and endocarp. In inferior fruits the concave receptacle remains adherent to the pericarp and forms part of the fruit. Combined epicarp and mesocarp are often called exocarp.

Perigynous, when the sepals, petals, and stamens are inserted round the superior ovary on the cuplike or tubular receptacle. The stamens also appear perigynous when inserted on the corolla.

Persistent, lasting until the fruit is ripe, as sepals or glumes; also applied to leaves remaining green during the winter: the opposite of caducous and deciduous.

Petal, one of the divisions or leaves of the corolla, usually colored.

Petaloid, resembling a petal.

Petiolate, supported on a petiole.

Petiole, stalk of a leaf.

retiolule, stalk of a leaflet. 
Phyllode (phy.lodium), a flat dilated petiole, fulfilling the functions of a leaf, as in many Acacias.

Pinna, a primary division of a pinnate leaf; a leaflet.

Pinnate, a compound leaf whose leaflets are arranged on each side of the common petiole or axis. When there is an odd terminal leaflet, the leaf is called unequally pinnate or imparipinnate. Also applied to lateral nerves arranged on each side of the midnerve of a leaf.

Pinnatifid, a leaf cut into lobes about half-way to the midrib.

Pinnatipartite, eut more than half-way to the midrib.

Pinnatisect, cut into segments nearly or quite to the midrib, but the segments not separating easily, as leaflets do.

Pinnule, the second or third division of a leaf which is twice or thrice pinnate or pinnatisect.

Pistil or gynoecium, the innermost and female part of the flower, consisting of one or more carpels. When there is only one carpel, the terms carpel, pistil, and gynoecium are synonymous. When two or more carpels adhere by their ovaries the pistil or gynoccium is compound or syncarpous (fig. 1). When the carpels are separate the pistil is apocarpous.

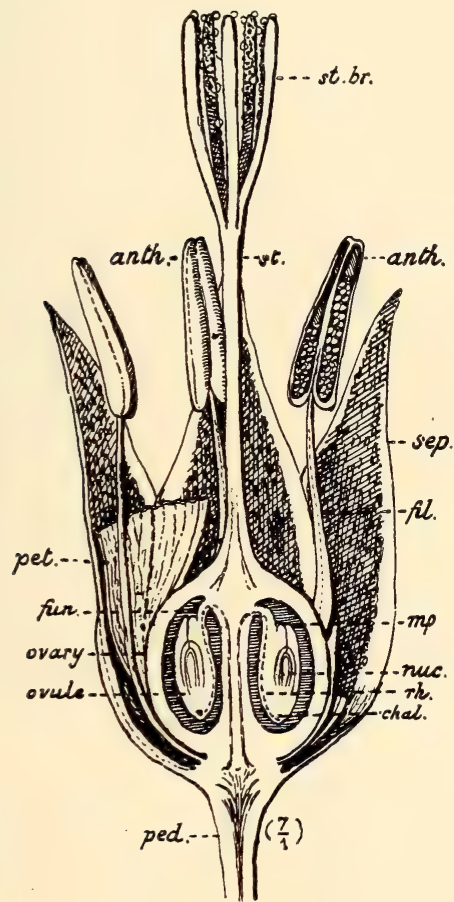

FIG. 2.-Vertical section of flower of Linum marginale. st.br. style-branches or free part of 5 united styles; st. style; anth. anthers opening in parallel slits; sep. sepals ; pet. lower part of one petal; the others removed; fil. filament; ovary, superior 5 -celled compound ovary, of 5 united carpels; ovule, anatropous pendulous ovule: fun. funicle; mp. superior (epitropous) micropyle; nuc. nucellus; $r h$. ventral rhaphe, i.e., from the position of the ovule the rhaphe is turned towards the ventral suture of the carpel; chal. chalaza; ped. pedicel.

Placenta, part of the ovary to which the ovules are attached by their funicles.

Plano-convex, flat on one side and convex on the other.

Plumose, when a hair or similar organ branches into rather long spreading secondary hairs, arranged irregularly or in two opposite rows like the barbs of a feather.

Pod, (1) the legume of Leguminosae, a dry fruit formed of a single carpel; (2) the siliqua and silicule of Cruciferae, a dry fruit composed of two earpels separated by a partition.

Pollen, see stamen.

Pollen-mass (pollinium), pollen-grains cohering by a waxy texture or fine threads into a single body.

Polygamous, when the same plant bears male, female, and bisexual flowers.

Posterior, the parts of a flower nearest to the axis of the branch.

Prickle, sharp excrescence arising from the bark and detachable without tearing the wood.

Procumbent, spreading along the ground, but not so closely as prostrate. 
Proliferous (viviparous), plants which bear adventitious leafbuds on the leaves or flowers, such buds being capable of rooting and forming separate plants.

Prostrate, lying flat on the ground.

Proximal, see distal.

Pubescent, downy, covered with short soft hairs.

Punctiform, like a point or dot.

Punctulate, finely dotted.

Putamen, a hard bony endocarp.

Raceme, an undivided axis or peduncle bearing pedicellate flowers.

Racemose, arranged in a raceme.

Radiate, a flowerhead of Compositare which has ligulate flowers in the circum. ference and tubular flowers in the centre.

Radical, springing from the root.

Radicle, see embryo.

Ray, (1) all the ligulate flowers (ray-flowers) in a radiate flowerhead; (2) each of the branches of an umbel.

Receptacle, (1) floral axis, torus or thalamus. The summit of the peduncle or pedicel on which the parts of a single flower are arranged, either in whorls or spirally. It may extend upwards as an annular or cushion-shaped disk, and this may assume the form of glands or scales, which often alternate with the stamens (Rutaceae, Zygophyllaceae). It may be lengthened into a column or carpophore, such as those which bear the fruitlets of Geraniaceae and Umbelliferae, or into a small stalk supporting the ovary (some Caryophyllaceae, Leguminosae, Proteaceae). It is very frequently hollowed out into a cup or rarely a tube, which surrounds the ovary and bears the sepals, petals, and stamens on or near its margin, and is usually united with the ovary, or more rarely free from it (Myrtaceae, Rosaceae, Oenotheraceae, Thymeiaeaceae). Formerly this hollow receptacle, when united with the ovary, was described as the "adnate (adherent) calyx-tube." (2) Floral base or common receptacle. The expanded summit of the peduncle on which the flowers, surrounded by an involucre of bracts, are inserted, usually in a dense cluster (Compositae, Dipsacaceae). In Compositae both forms of the receptacle are present.

Recurved (reflexed), bent backward.

Reduplicate-valvate, when the edges of petals or sepals are turned backward and outward in the bud (see figure of Boronia palustris).

Regular, a flower in which the segments of the perianth, or the parts of either of the 2 whorls of the perianth (calyx and corolla) are alike in size and shape (although in the latter case the 2 whorls need not have the same number of parts), and are arranged regularly round the axis. The term regular is thus practically equivalent to actinomorphic, or radially symmetrical, i.e., where a flower can be bisected through two or more vertical planes into two similar halves. Such flowers are Buttercup, Poppy, Boronia, Geranium, the Cruciferous Family, \&e.

Reniform, kidney-shaped.

Replum, a partition between the two carpels of the ped of Cruciferae.

Resupinate (reversed), when a flower is inverted by a twisting of the pedicel or the ovary so that the parts usually uppermost become the lowest.

Reticulate, when the nerves or veins cross each other like the meshes of a net.

Revolute, when the edges of leaves are rolled backwards towards the midrib (see illustrations of Frankenia).

Rhachilla, the rhachis of the spikelet in grasses and sedges.

Rhachis, any principal axis of inflorescence; also applied to the common petiole of a compound leaf.

Rhaphe, a cord adhering to one side of an anatropous ovule and connecting the chalaza with the placenta. It is often visible as a raised line on the seed (see fig. 2 and illustration of Frankenia pauciflora).

Rhizome (rootstock), an underground creeping stem which grows more or less horizontally and emits roots downwards and buds and shoots upwards. When the axis is shortened and more or less covered with scales, the rhizome becomes a bulb or a corm.

Rhomboid (rhomboidal), lozenge-shaped.

Root, the descending axis of the plant, developed from the radicle, and imbibing nourishment through its fibres.

Rostellum, an extension of the upper edge of the stigma in orchids.

Rostrate, beaked.

Rotate, wheel-shaped, a corolla with very short tube and spreading limb. 
Runcinate, a pinnatifid leaf with lobes pointing towards the base.

Sagittate, arrow-shaped; applied to a leaf with two straight acute lobes at the base.

Samara, a dry indehiscent fruit with a membranous wing at one end.

Scabrous, rough to the touch, usually on account of very short stiff hairs.

Scale, (1) a reduced leaf; (2) any small scale-like organ.

Scape, a radical leafless flowerstalk.

Scarious, almost the same as membranous, but rather stiffer.

Suattered, when leaves are irregularly arrarged round the stem.

Scorpioid cyme, the inflorescence of Borraginaceae, consisting of a succession of 1-flowered axes, which simulate a single axis, rolled up at the end, when in bud, like a scorpion's tail. It has the appearance of a 1-sided raceme, but the expansion of the flowers is centrifugal.

Scurfy, covered with minute loose scales.

Sectile, subdivided into small parts, as the pollen-masses of some Orchids.

Secd, a ripened ovule, consisting usually of two eoats, within which is the embryo, with or without albumen.

Segment, (1) each division of a pinnatisect leaf which reaches nearly or quite to the midrib, but is not separable without tearing; (2) each division of a perianth reaching to the base.

Sepal, one of the divisions of the calyx.

Septal placenta, when the placentas of a 2-celled ovary are attached to the partitions (septa).

Septate, divided by septa or partitions.

Septicidal, when a capsule splits open through the dissepiments, and the component carpels fall away separately.-Zygophyllum fruticulosum, Dodonaea bursarifolia, Euphorbia.

Septifragal, when the dissepiments remain attached to the axis of the capsule, but break away from the edges of the valves.-Dodonaea viscasa, Nicotiana suaveolens, Datura Stramonium.

Serrate, toothed like a saw.

Serrulate, when the teeth are very small.

Sessile, without any stalk.

Seta, a bristle or stiff hair.

Setaceous, bristle-like.

Silicule, siliqua, see pod.

Simple, when a leaf is not divided into leaflets, the opposite of compound, although a simple leaf may be entire, toothed, or lobed; (of other organs) not lobed, branched, divided, or compound; (of a flower or perianth) having the segments or lobes in one whorl or cycle.

Sinuate, leaf or other organ whose edge consists of shallow irregular lobes or teeth, with rounded spaces, ealled sinuses, between them.

Spathe, (1) two or more bracts enclosing the floors of Iridaceae; (2) a large bract enclosing the succulent flowerspike (spadix) of the Arum and Palm families.

Spathulate, a leaf broad towards the summit, narrowed lower down.

Species, a division of the genus, each species (group of individual plants) possessing characters which distinguish it from other species of the same genus. Each species bears two names, e.g., Eucalyptus rostrata, the first being the generic name, the second the specific one.

spicate, arranged in a spike.

Spike, an undivided floral axis (rhachis, peduncle) bearing sessile flowers.

Spitelet, a small spike bearing one or several flowers, oceurring chiefly in the grass family.

Spine (thorn), a sharp point proceeding from the. stem or other organ and not detachable without tearing.

Spinule, a small spine.

Stamen, male organ of the flower, consisting of a short or long stalk (sometimes wanting) called the filament, which supports the anther. The latter consists of one or two pouches, or cells, containing the minute pollen-grains, by means of which the pistil is fertilised (fig. 2).

Staminodium, an abortive or rudimentary stamen.

Standard, the large posterior petal of Papilionatae (Leguminosae).

Stellate hairs, hairs with branches radiating like a star.

Stem-clasping (amplexicaul), when the base of a sessile leaf clasps the stem. 
Stigma, a point or small head at the summit of the style; or the stigmas may occupy the inner face of the style-branches (Ccmpositae) or the spreading hairs of the styles (Gramineae). Where there is no style, the stigma is sessile on the ovary. It is sticky and papillose and reccives the pollen from the anthers.

Stigmatic plate, the front part of the column in certain genera of Orchids, bearing the female elements, and composed of a pedicel (or expanded style), carrying a vertical plate on the face of which are the stigma, the rostellum, and the viscid disk.

Stipellae, two small secondary stipules sometimes found at the base of leaflets.

Stipes, a small stalk, especially one rising above the insertion of the perianth and supporting a fruit, when it is the equivalent of a small gynophore; also applied to the stalks of scales and bracts.

Stipitate, supported on a stipes.

Stipules, two small appendages growing at the base of the leafstalk.

Stolon (runner, sucker), a basal branch growing just above or just below the surface, rooting at intervals and producing new plants.

Striate, marked with parallel, longitudinal lines.

Style, the narrow upper part of the carpel or pistil; it surmounts the ovary and supports the stigma, but is sometimes wanting (fig. 2).

$S u b$, a prefix meaning (1) somewhat, almost, as in suberect, subglobular; (2) under, inferior, as in subfamily.

Subulate, awlshaped.

Superior.-An ovary is superior or free when the calyx, corolla, and stamens are inserted below it on the floral axis, or when the hollow receptacle is not united with it. In the first case the calyx, corolla, and stamens are hypogynous or inferior (fig. 2), and in the second case they are inserted on or near the margin of the hollow receptacle and so become perigynous. A Superior radicle points towards the summit of the fruit, and a superior (epitropous) micropyle points to the summit of the ovary.

Superposed, inserted one above the other.

Suture.-The dorsal suture of a carpel (carpellary leaf or fruit-leaf) represents the midrib of the leaf; it is the outer (anterior) suture or seam. The ventral suture is on the inner side of the carpel and indicates the line where the edges of the folded leaf have become united; it bears the placenta and ovules. Dehiscence may take place through one or both sutures.

Sympeta? ous, a corolla in which the petals are united by their edges into a cup or tube. Less correctly called gamopeta'ous or monopetalous.

Syncarpous, an ovary, pistil, or fruit composed of two or more united carpels.

Tendrils, filiform organs by which climbing plants eling to some object within reach.

Terete, slender-cylindrical, but not so slender as filiform.

Ternate, arranged in threes.

Testa, the outer seedcoat.

Tomentose, densely covered with short soft matted hairs (tcmentum).

Toothed (dentate), notched so as to resemble a row of sharp teeth.

Torus, see receptacle.

Trichotomous, stem or branches divided into three, once or several times.

Trifid, cut about half-way into three parts.

Trifoliolate, a leaf of three leaflets.

Trigonous, a stem or other organ which is triangular when eut transversely.

Tripartite, divided into three parts nearly to the base.

Tripinnatisect, thrice pinnatisect.

Triquetrous, a triangular stem or other organ when the angles are sharp.

Trisect, cut into three segments to the base of midrib.

Truncate, cut off squarely.

Tuber, (1) a swollen branch of an underground stem, producing buds, as the potato; (2) a swollen part of a root, acting as a reservoir of nourishment.

Tubercle, a small wartlike protuberance.

Tuberculate, covered with tubercles.

Tunic, the outer covering of some bulbs and corms.

Turbinate, top-shaped.

Umbel, inflorescence where the divergent branches or rays start from the same point. In a simple umbel each ray bears one flower.

Umbellule, a partial umbel borne at the summit of each ray of a compound umbel.

Umbilicate, with a conspicuous depression in the centre.

Umbonate, bearing a small boss or elevation in the centre. 
Undenshrub, a small shrub whose flowering branches die off in the winter.

Undulate (crisped), wavy on the edges.

Unilateral, one-sided.

Unisexual, a flower of one sex, either male or female.

Utricle, a very thin loose covering of some fruits.

Valvate, petals and sepals whose edges, in bud, meet without overlapping.

Valve, one of the pieces formed by the vertical splitting of the pericarp of certain fruits when ripe. The valves usually consist of the backs of the carpels.

Variety, subdivision of a species.

Vascular bundles, long tubes or fibres which establish communication between the various parts of a plant. An open vascular bundle is one divided by a layer of cambium, so that the bundle is capable of constant growth; a closed bundle (as in Vascular Cryptograms and Monocotyledons) has no cambium and cannot increase in size.

Ventral, see suture.

Versatile, when the anther is lightly attached by some point of its back to the filament, so as to swing easily.

Vitlous, beset with long soft hairs.

Vitta, linear longitudinal vessel in the fruit of some Umbelliferae.

Viviparous, see proliferous.

Whorl (verticil), a set of organs, proceeding from the same node, and arranged in a circle around the axis.

Whorled (verticillate), arranged in a whorl.

Wing, (1) any kind of flat membranous expansion; (2) one of the two lateral petals of papilionate flowers.

Zygomorphic, see irregular. 


\section{SCALE OF MEASUREMENTS.}

As in most modern floras, including those published in other English-speaking countries, the metric system has been here adopted for describing the size of flowers, leaves, and other parts of a plant. The contractions are: m., metre; cm., centimetre ; mm., millimetre

$$
\begin{aligned}
1 \text { line } & =2.1 \mathrm{~mm} . \\
3 \text { lines }\left(\frac{1}{4} \mathrm{inch}\right) & =6.3 \mathrm{~mm} . \\
6 \text { lines }\left(\frac{1}{2} \mathrm{inch}\right) & =12.7 \mathrm{~mm} . \\
1 \text { inch } & =25.4 \mathrm{~mm} . \text { or } 2.5 \mathrm{~cm} . \\
2 \text { inches } & =5.0 \mathrm{~cm} .
\end{aligned}
$$

\section{CENTIMETRES.}

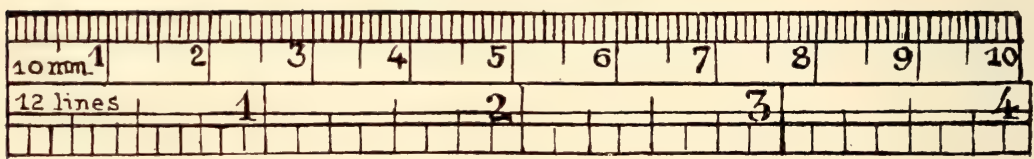

\section{INCHES.}

$10 \mathrm{~cm} .=4$ inches $($ nearly $)$.

$30 \mathrm{~cm} .=1$ foot (nearly).

$1 \mathrm{~m} .(100 \mathrm{~cm})=$.3 feet $3 \frac{1}{2}$ inches (nearly).

$5 \mathrm{~m} .=16 \frac{1}{2}$ feet (nearly).

$10 \mathrm{~m} .=33$ feet (nearly). 


\section{KEY TO THE FAMILIES.}

A. Plants without flowers; reproduction by spores Division 1

A. Plants with flowers; reproduction by pollen and ovules, the latter ripening into seeds........... Division 2

B. Seeds naked, i.e., not enclosed in an ovary; no perianth $\ldots \ldots \ldots \ldots \ldots \ldots . \ldots . \ldots . \ldots$ Subdivision 1

B. Seeds enclosed in an ovary; perianth usually present ......................... Subdivision 2

C. Embryo with 1 cotyledon; leaves usually with parallel nerves ; perianth frequently of 2 whorls of 3 parts each, but sometimes absent ....... Class 1

C. Embryo with 2 cotyledons; nerves of the leaves branching pinnately and often reticulate; perianth usually in 1 or 2 whorls of 4 to 5 parts each Class 2

Petals, when present, usually free; perianth simple and petaloid or herbaceous, or divided into calyx and corolla, or sometimes absent...... Subclass 1

Petals usually united into a corolla ; perianth always double, but calyx sometimes inconspicuous

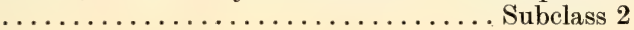

PTERIDOPHYTA.

SPERMATOPHYTA.

Gymnosperms.

Angiosperms.

Monocotyledons.

Dicotyledons.

Archichlamydeat.

Metachlamydeae.

\section{DIVISION 1.-PTERIDOPHYTA (VAScular CRYPTOGaMS).}

A. Class FILICALES (Fernlike Plants). Leaves large, usually divided or pinnatisect, with small spore-cases in clusters on the undersurface.

B. Spores of one kind.

C. Spore-cases with a ring.

Spore-cases with a complete oblique ring; tree-ferns

Spore cases with an incomplete longitudinal ring, and

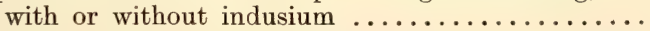

Spore-cases few, with a transverse ring and opening by a longitudinal slit; no indusium ........... Spore-cases sessile in 2 rows, with a complete ring at the summit and a longitudinal slit; no indusium...

C. Spore-cases without a ring; no indusium.

Spore-cases clustered, stalked, with a longitudinal

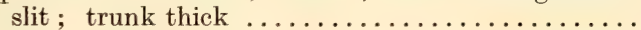

Spore-cases in 2 rows along the spike like fertile leaf, and opening in a longitudinal slit..........

B. Spores of 2 kinds, producing male and female prothalli.

Spore-cases containing both sexes within 2 fertile leaves united in the form of a capsule ; barren leaf usually of 4 leaflets $($ Nardoo $) \ldots \ldots \ldots \ldots \ldots \ldots \ldots$.

Spore-cases of 1 sex only, within the fruiting leaves;

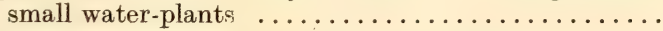

A. Class IYYOPODIALE' (Plants like Clubmoss). Leaves small, undivided; spore-cases solitary, sessile in the axils of the leaves.

D. Spores of one kind; moss-like plants with small stemleaves, or (in Phylloglossum) with linear radical leaves

Cyatheaceae 1 .

Polypodiaceae 2.

Gleichentaceae 3.

Schizanaceat 4 .

OSMUNDACEAE 5 .

OPhioglossaceae 6.

Marsiliaceae 7 .

Salviniaceae 8.

LyCOPODIACEAE 9.

D. Spore-cases of 2 kinds.

Moss-like plants ; macrosporangia usually with 4 spores

Small plants with radical filiform leaves; macrosporangia with numerous spores $\ldots \ldots \ldots \ldots \ldots \ldots \ldots$ Isomtacene 11.

DIVISION 2.-SPERMATOPHYTA (PHANEROGAMS).

SuBDIVISION 1.-GYMNOSPERMS.

Trees or shrubs with leaves like needles or scales; ovules naked on the upper surface of scales; fruit a hard cone

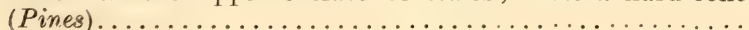


A. Marsh or water plants.

SUBDIVISION 2.-ANGIOSPERMS.

Class 1.-MONOCOTYLEDONS.

B. Perianth absent; seeds albuminous.

Tall aquatic plants ; flowers in dense velvety spikes..

Minute floating plants, with leaf-like laminas, often bearing roots on the under-surface............

B. Perianth usually present; seeds exalbuminous.

C. Perianth of few segments or wanting; stamens and carpels usually $1 \cdot 4$. water-plants.

Leaves entire; perianth of 4 segments or wanting Leaves toothed; female perianth a cup-shaped

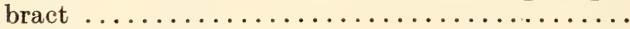

C. Perianth of 2 petaloid segments; stamens 6-18;

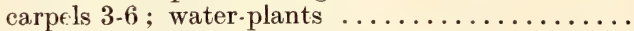

C. Perianth of 6 herbaceous segments in 2 whorls ; anthers and fertile carpels 6 or 3 ; marsh plants.......

C. Perianth of 6 segments, the inner 3 petaloid; marsh plants.

Flowers bisexual ; carpels 6 or more, free; ovary

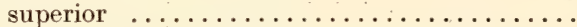

Flowers mostly unisexual; ovary inferior, 1celled (Halophila is a marine plant with inconspicuous perianth) $\ldots \ldots \ldots \ldots \ldots \ldots \ldots$.

A. Mostly land plants ; sometimes growing near water ; seeds albuminous (except in Orchidareae).

D. Perianth wanting; ovary superior, 1-celled, 1-ovuled; each flower sheltered by small boat-shaped bracts called qlumes: leaves narrow (Order Glumiflorae).

Stems hollow and interrupted by nodes; !eaf-sheaths slit downwards, flower enclosed in 2 bracts (Grasses)

Stems solid, withont nodes; leaf-shenths not slit; flower in the axil of 1 brict (Sedge Family).....

D. Perianth present.

E. Perianth conspicuous, of 6 segments in 2 rows, all, or the inner ones, petaloid; flowers usually bisexual.

F. Ovary superior, usually 3 -celled.

All the segments or lobes petaloid; stamens usually 6 (Lily Family) . . . . . . . . . . . . Outer segments irregular; 3 inner segments united at base, yellow, perfect stamens $3 \ldots \ldots$.

Three inner segments free, blue..............

F. Ovary inferior.

G. Flowers regular, or nearly so ; ovary 3-celled.

Stamens 6 ; anthers opening inwards.......

Stamens 3 ; anthers opening outwards (Iris

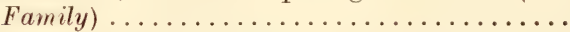

G. Flowers usually irregular; stamens and style combined in a column; ovary 1-celled

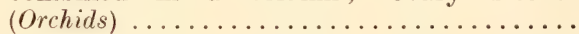

E. Perianth of glume-like segments, rarely wanting; ovary superior, 1-3-celled.

H. Flowers bisexual ; segments 6 ; stamens 6 or 3 ; ovules several in each cell ; leaves narrow, mostly

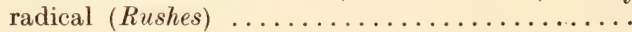

H. Flowers bisexular or unisexual; ovary with 1 pendulous ovule in each cell.

Segments 6 or fewer; stamens 3 ; leaves mostly reduced to sheathing bracts along the stem and split open on one side (Rush-like Plants): .

Segments reduced to 1-3 minute scales or absent; ovary 1 or of several superposed carpels; stamen 1 ; leaves filiform, radical; small

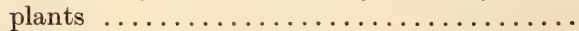

Segments small, 4-6 ; stamens 6 ; flowers in a head ; leaves radical. .................

Typhaceae 13.

LemnaCeat 23.

Potamogetonaceae 14.

NAJADACEAE 15.

Aponogetonaceae 16.

SChedChzeriaceae 17

Alismataceae 18.

Hydrocharitaceae 19.

Gramineae 20.

Cyperaceae 21.

Liliaceae 29.

XYRIDACEAE 25.

Commeitinaceae 27.

Amaryllidaceae 30 .

IRIDACEAE 31.

Orchiddacae 32 .

JuncaCeae 28.

Restionaceae 23.

Centrolepidaceae 24.

Eriocaulaceae 26. 


\section{Class 2.-DICOTYLEDONS.}

Subclass 1.-ARchichlamydeaE.

Plants whose perianth occupies a lower stage of development. Some have neither calyx nor corolla (achlamydeous) ; others have a perianth which is all either petal-like or sepallike, and may be simple (haplochlamydeous, monochlamydeous) or double (diplochlamydeous), and in the latter case the 2 whorls may be dissimilar (sepals and petals), and the petals are then usually separate from each other (choripetalous flower).

There are, however, some exceptions. The petals are more or less united (usually near their bases) in Stackhousia, Fumaria, and Olax, in many Acacias, in Polygalaceae, Papilionatae, Malvaceae, and Oxalidaceae, and in some genera of Pittosporaceae and Rutaceae. The petaloid segments of Loranthus and of Proteaceae and Nyctaginaceae are also more or less united. Petals are sometimes absent in a particular genus, although they may be characteristic of the family; such cases are Pomaderris (Rhamnaceae), Brachychiton (Sterculiaceae), Dodonaea (Sapindaceae), and some genera of Euphorbiaceae, Rosaceae, and Lythraceae.

\section{Ovules with many embryo-sacs (macrospores).}

Order Verticillatae.

Flowers unisexual; male flowers in catkins; female without perianth; fruit a cone ; leaves reduced to whorls of small teeth $($ Sheoak $) . \ldots \ldots \ldots \ldots \ldots \ldots$

Casuarinaceae 33 .

2. Ovules with usually only 1 embryo-sac.

A. Flowers naked or with a simple bract-like perianth.

Order Urticales. Flowers unisexual; perianth of usually 4 segments; carpel 1; ovary superior, 1-ovuled; albumen scanty.

Trees with milky sap; flowers enclosed in a hollow receptacle which becomes the fruit $(f i g) \ldots \ldots \ldots \ldots$. Herbs with opposite leaves and stinging hairs (Nettle)..

A. Flowers with a simple or double bract-like or sometimes petaloid perianth.

B. Order Proteales. Perianth simple, petaloid; stamens 4, inserted on the 4 segments; carpel 1, superior; nut, drupe, or hard follicle; seed exalbuminous (Needle-

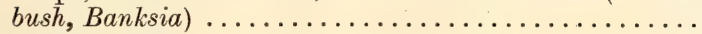

B. Order Santalales. Flowers regular ; carpels 1-3 united ; ovary 1-celled, usually inferior; seeds albuminous.

C. Perianth-segments in 1 whorl, petaloid; flowers bisexual or unisexual; parasites.

Segments 4-5, with the same number of stamens opposite them; ovary 1-celled, with $2-5$ ovules on a central placenta; nut, drupe or berry; shrubs

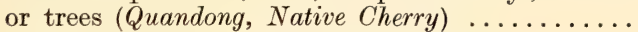
Segments 4-6, free or united, with the same number of stamens inserted on them; ovary inferior, 1-celled, 1-ovuled; berry sticky; leaves opposite

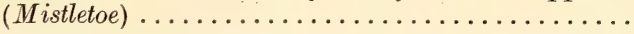

C. Perianth-segments in 2 whorls; calyx 4-6-toothed; petals 4-6; ovary superior; drupe ; shrub.....

B. Order Polygonales. Perianth-segments 3-6, herbaceous, in 1 or 2 whorls ; flowers regular, bisexual or unisexual; stamens 6-9; ovary superior, 1-celled, 1-ovuled, with 2-4 styles; embryo usually straight; angular nut; stipules sheathing the stem; herbs or shrubs (Dock,

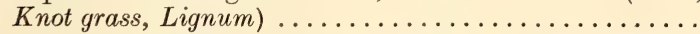

B. Order Centrospermae. Flowers regular ; stamens usually as many as and opposite the perianth-segments ; ovary usually of several united carpels, 1-celled, with 1 or more ovules; embryo usually much curved round the albumen, which is sometimes absent.

D. Perianth simple, except in some Aizoaceae.

E. Flowers bisexual or unisexual ; ovary superior.

Perianth herbaceous, of $1-5$ lobes or segments; stamens opposite segments; ovary 1-celled, with 1 basal ovule; styles 2-3; flowers small, sometimes immersed in fleshy branches; herbs or undershrubs (Goos foot, Saltbush, Samphire)....

MORACEAE 34.

URTICACEAE 35.

Proteaceae 36.

SANTALaCEAE 37.

LORANTHACEAE 39.

Olacaceae 38.

Polygonaceae 40.

Chenopodiaceae 41 . 
Perianth-segments 5, scarious or colored; stamens opposite them ; ovary 1-celled, 1-ovuled; styles 1-3; leaves entire; herbs or undershrubs....

Perianth 5-lobed, petaloid, the lower part hardened and persistent; stamens usually 1-4; carpel 1, 1-ovuled; style simple; herbs.............. Perianth 4-5-lobed, herbaceous or somewhat scarious; stamens 4-5, or many; earpels 1 celled, 1-ovuled, 2 or many, separate or united in a ring, each with a distinct style; leaves

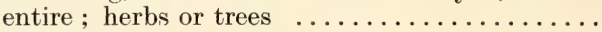

E. Flowers bisexual; perianth of 4-5 herbaceous lobes or segments; stamens 4-5, rarely 8-10, or many, and then the outer ones changed into petals ; ovary superior or inferior, 2 -several-celled, rarely 1-celled; styles as many as cells; leaves often succulent;

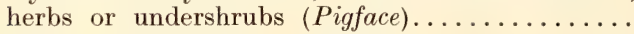

D. Perianth double; whorls dissimilar ; flowers bisexual. Sepals 2 ; petals 4-5 ; stamens 5-many ; ovary superior or half-inferior, 1-celled, with 2-many ovules on a free central placenta; capsule; succulent herbs

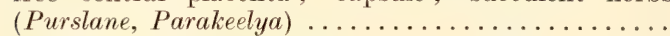

Sepals 4-5; petals as many, rarely absent; stamens usually twice as many ; ovary superior, l-celled, with $2-5$ styles; ovules usually many on a free central placenta; herbs with opposite entire leaves (Pink

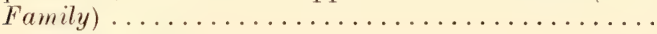

A. Flowers almost always with calyx and corolla.

F. Pistil often apocarpous or sometimes syncarpous, with 1-several cells.

Order Ranales. Perianth of 1 or 2 whorls; stamens usually numerous; ovary superior.

G. Anthers opening by slits; stamens hypogynous.

Flowers simple, unisexual, with 9-12 minute perianthsegments; stamens 12-16; carpel solitary, with 1 pendulous ovule; albumen scanty; leaves

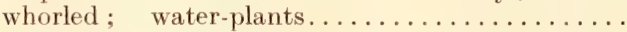

Flowers bisexual, usually regular; sepals and petals usually 5; petals absent in Clematis ; stamens numerous; carpels several ; achenes; albumen copious; herbs (Buttereup)...............

G. Anthers opening by valves from the base upwards; stamens perigynous; flowers bisexual, regular; perianth-segments 6 , in 2 rows, similar, small; stamens 12 , of which 3 are reduced to staminodia; carpel solitary, 1-ovuled; no albumen; leafless

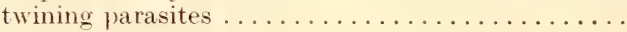

F. Pistil often, syncarpous; ovary usually superior ; stamens hypogynous or perigynous.

H. Order Rhoeadales. Flowers bisexual, usually double ; carpels 2-many, united in a superior, usually 1 -celled ovary; styles very short or absent.

I. Sepals 2 (rarely 3 ); seeds albuminous; flowers regular, or (in Fumaria) irregular; petals 4 (rarely $6)$; stamens many, free, or 6 in 2 bundles; capsule with many-seeded parietal placentas, or (in Fumaria) a 1-seeded nut; herbs (Poppy, Fumitory)

\section{Amarantaceae 42 .}

Nyctaginaceae 43.

Phytolaccaceae 44.

Aizonceat 45.

Portulacaceae 46.

Caryophyllaceae 47.

Ceratophyllaceae 48.

RanunCulaceae 49.

Lauraceae 50.

Papaveraceae 51

I. Sepals 4-6; seeds without albumen.

J. Flowers regular; sepals and petals 4 .

Stamens 8-many; ovary usually stalked, 1celled, with several parietal placentas; capsule or berry; herbs or shrubs (Caper

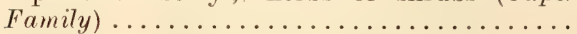

Stamens 6 or 4 ; ovary with placentas along the sutures; pod long or short, usually divided into 2 cells by a membranous partition, sometimes splitting into articles : herbs (Stock,

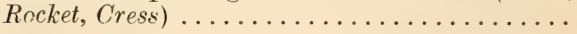


J. Flowers irregular; sepals and petals 4-6, the petals more or less cleft, stamens many, on a disk be!ow the ovary, ovary 1-cellet, open at the summit, with $3-\frac{1}{2}$ parietal placentas, bearing numerous ovules (Mignonette) ...........

H. Order Sarracenia es. Flowers regular; sepals, petals, and stamens 4-5; ovary superior, with $3-5$ parietal placentas and styles; capsule; herbs with glandularhairy insectivorous leaves; seeds albuminous (Sundew)

H. Order Rosales. Flowers double; carpels solitary or several together, distinct or united; ovary superior, except in some Saxifragaceae and Rosaceae.

K. Seeds with copious albumen and small embryo; flowers regular, bisexual.

Sepals and petals 4-9; stamens numerous, on a small disk; ovary superior or nearly so, 2-celled, with parietal placentas, many ovules and 2 free styles; shrub with opposite trifoliolate leaves

Sepals and petals 5 ; stamens 5 ; ovary 1 -celled, with 2-5 parietal placentas, or more or less 2-5celled; style simple ; capsule or berry; trees, shrubs, or twining undershrubs...........

Resedaceae 54.

Droseraceae 55.

Saxifragaceat 57.

Pittosporaceae 58.

K. Seeds with little or no albumen.

L. Seeds usually several, attached to the ventral suture in 2 rows.

Flowers regular, bisexual ; sepals, petals, stamens, and distinct carpels $4-5$; succulent

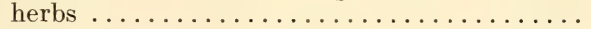

Flowers bisexual, regular (in Mimosoideae), slightly irregular (in Caesalpinioideae), very irregular (in Papilionatae); calyx-lobes 5; petals 5, often partly united; stamens usually 10, or (in Acacia), numerous ; carpel solitary ; fruit a pod; trees, shrubs, or herbs (Peaflower,

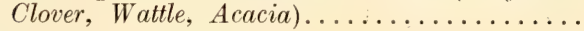

L. Seeds 1-2 in each carpel.

Flowers usually bisexual and regular; sepals and petals usually 4-5; petals sometimes wanting; stamens numerous; carpels 1-many, superior or united to the wall of the hollow receptacle; shrubs or herbs (Rose Family).............

H. Order Geraniales. Sepals and petals 5, sometimes united at base, rarely absent ; ovary superior, severalcelled, of united carpels, which often separate when ripe; ovules usually 1-2 in each carpel, anatropous, either pendulous with a vental rhaphe and superior (epitropous) micropyle, or, when more than 1 ovule is present, some are ascending with a dorsal rhaphe and inferior (apotropous) micropyle.

M. Sepals and petals present; flowers bisexual.

N. Anthers opening by longitudinal slits ; flowers usually regular; seeds usually with scanty albumen or none.

O. Sepals and petals 5 ; stamens usually 10 , often united at base.

P. No disk.

Fruit separating into 5 fruitlets with awns (styles) elastically rolled upwards; herbs or undershrubs (Crane's-bill)..............

Fruit a 5-celled capsule opening by valves; herbs (Woodsorrel, Soursob) ............

P. An entire or divided disk present, below or around the ovary; sepals and petals 4-5; stamens as many or double as many.

Leaves of 2 leaflets or pinnate, stipulate, without glandular dots; ovary 4-5 celled, with 1 style (Nit aria has no disk, 15 stamens and simple leaves); capsule, drupe or fruitlets;

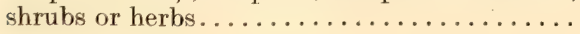

Crassulaceae 56.

Leguminosae 60 .

Rosaceae 59.

Geraniaceae 61 .

OXalidaceae 62 .

ZygOPHYLLACEAE 64. 
Leaves without stipules and with glandular dots; carpels and styles 4-5, more or less:

O. Sepals, petals and stamens 5 ; ovary 5 -celled, with

5 styles ; capsule ; herbs (Flax) ..............

N. Anthers opening by terminal pores; ovary 2 -celled; style simple; compressed capsule.

Flowers regular; sepals and petals 4-5; stamens twice as many; anthers 2-4-celled; heath-like shrubs. .

Flowers irregular; sepals 5, the 2 inner ones larger and petaloid; seeds hair-tufted in Comesperma; herbs or undershrubs (Milkwort) ............

M. Sepals and petals reduced or absent; flowers unisexual ; albumen copious.

Capsule usually splitting into 3 2-valved fruitlets, which separate from the persistent axis; sepals 4-5 (absent in Euphorbia); petals 4-5, sometimes absent; stamens 1-many; seeds often caruncu-

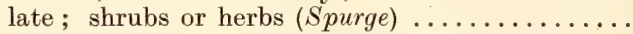

Fruit dividing into 4 fruitlets without persistent axis; stamen 1; leaves opposite; aquatic herb

H. Order Sapindales. Like Geraniales (ovary superior), but the arrangement of the ovules on the placenta is reversed ; the ovules are either pendulous with a dorsal rhaphe and superior micropyle, or ascending with a ventral rhaphe and inferior micropyle.

Flowers regular, bisexual; sepals and petals 5, free or united; stamens 5; ovary 3-5-celled; fruitlets 3-5, separating from the persistent axis ; albumen present ;

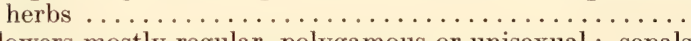

Flowers mostly regular, polygamous or unisexual ; sepals and petals 4-5, or petals wanting (in Dodonaea); stamens usually 8 , between disk and ovary; ovary usually 3-celled; fruit often a winged capsule; no albumen;

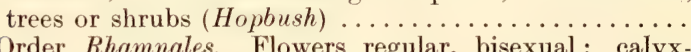

H. Order Rhamnales. Flowers regular, bisexual; calyxlobes 4-5, often caducous; petals perigynous, minute, 4-5, or none ; stamens 4-5, opposite the petals ; ovary 2-4-celled, superior or almost inferior; drupe or capsule ; seeds usually albuminous ; shrubs (Buckthorn,

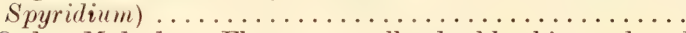

H. Order Malvales. Flowers usually double, bisexual and regular ; sepals and petals usually 5 ; stamens 5-many, often united; carpels united in a many-celled superior ovary; seeds albuminous.

Q. Anthers 1-celled; calyx 5-lobed; petals cohering at base ; stamens many, united in a tube surrounding the pistil ; fruit dividing into many fruitlets or united in a capsule; herbs or shrubs (Mallow Family)..........

Q. Anthers 2-celled; ovary 2-5 celled.

Sepals and petals 4-5; stamens few to many ; style

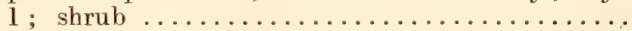

Calyx 5-lobed; petals sometimes minute or wanting; stamens $10-15$, united in a tube, or 5 , free or united, sometimes with alternating staminodia; styles as many as cells, more or less united; shrubs or trees (Kurrajong) . . . . . . . . . .

F. Pistil syncarpous (carpels almost free in Dilleniaceae); ovary superior; stamens hypogynous.

Order Parietales. Flowers double ; pistil composed of 2 or more carpels, which are usually united in a 1-celled superior ovary.

R. Flowers regular, bisexual.

Sepals and petals 5 ; stamens few to many; carpels $2-5$, almost free; seeds few, albuminous, with an arillus; small heath-like shrubs (Hibbertia)......

Sepals and petals 5; stamens numerous, united in bundles ; ovary 1-celled, with 3-5 parietal placentas and styles; seeds numerous, exalbuminous; herbs with opposite dotted leaves (St. John's Wort)....

Rutaceae 65.

LINACEAE 63.

Tremandraceae 66 .

Polygalaceae 67.

Euphorbiaceae 68.

Callitrichaceae 69 .

Stackhousiaceae 70 .

Sapindaceae 71.

Rhamnaceae 72 .

Malvaceae 74.

Tiliaceae 73.

Sterculiaceae 75.

Dilleniaceae 76 .

GutTiferae 77. 
Sepals, petals, and stamens 3-5 ; ovary with 3-5 cells and styles; water-plants with opposite or whorled

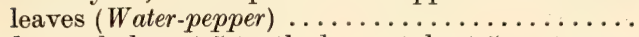

Calyx tubular, 4-5-toothed; petals 4-5; stamens 4-6; ovary 1-celled, with 2-3 parietal or basal placentas; seeds albuminous; heath-like undershrubs with opposite or whorled leaves.........

Elatinaceae 78.

Frankeniaceae 79.

R. Flowers irregular or (in Hymenanthera) almost regular, bisexual; sepals, petals and stamens 5, the lowest petal usually larger or spurred; ovary 1-celled, with 3 parietal placentas; capsule or berry; herbs or

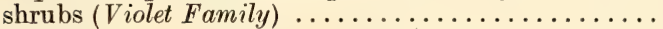

F. Pistil syncarpous (except in Thymelaeaceac), the ovary sunk in the cupshaped or tubular receptacle, and either united with it and inferior (with epigynous perianth and stamens), or free within it and superior (with perigynous perianth and stamens).

S. Order Myrt,florae. Flowers simple or double; ovary usually of 2 -several united carpels.

T. Perianth simple, of 4 sepals inserted at the summit of the tubular petaloid receptacle; stamens 2 , on the tube; ovary superior, 1-celled, 1-ovuled;

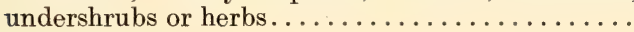

T. Perianth double.

U. Ovary 1-several-celled, with 1 style; flowers regular, bisexual.

V. Stamens as many, or double as many, as the petals or calyx-teeth, rarely fewer; seeds without albumen.

Sepals and petals 3-5, at the summit of the tubular receptacle; petals rarely absent; stamens 2-12, on the tube a little below the petals; ovary superior, 2-5-celled, with 1 style; herbs with opposite leaves (Loosestrite)

Sepals and petals 4-6, at the summit of the tubular receptacle; stamens twice as many; ovary inferior, adnate to the tube, 4-6-celled; capsule; style 1 ; seeds hair-tufted in Epilobium, herbs (Evening Primrose).....

V. Stamens numerous; sepals and petals usually 4-5 (consolidated in a cap in Eucalyptus); stamens many or rarely few, sometimes united in bundles; ovary inferior, united with the cuplike receptacle, 1-several-celled, with 1 style; seeds exalbuminous; trees or shrubs (Gum, Mallee, Teatree, Bottlebrush) ........

U. Ovary 1-4-celled, with as many styles as there are cells; flowers bisexual or unisexual, regular ; sepals and petals $2-4$; stamens $2-8$; ovary inferior, united with the cupshaped receptacle; seeds albuminous: herbs or water-plants

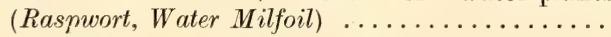

S. Order Umbelliflorae. Flowers usually bisexual and regular, arranged in umbels; calyx of 5 small teeth or absent; petals and stamens 5 , inserted round a disk at the summit of the 2-celled inferior ovary; styles 2 ; fruit separating into 2 ribbed fruitlets; albumen corious; herbs (Carrot, Celery, Fennel)............
Thymelaeaceae 81 .

Lythraceae 82.

OENOTHERACEAE 84

Myrtaceae 83.

Halorrhagidaceat 85.

UMBELLIFERAE 86.

\section{Subclass 2.-Metachlamydeae.}

Perianth in a more advanced stage of development, always double, and its inner whor usually united into a corolla (sympetalous flower).

A. Ovary superior; calyx and corolla hypogynous; stamens hypogynous, or (by adhesion of the filaments to the corolla) perigynous. 
B. Order Ericales. Flowers regular, bisexual; sepals 5; corolla 5-lobed; stamens 5, opposite the corollalobes and usually inserted on the tube; ovary 5celled, with 1 style; seeds albuminous; leaves rigid, entire; shrubs $($ Heath $) \ldots \ldots \ldots \ldots \ldots \ldots \ldots \ldots$. . . . . . . . . . .

B. Order Primulales. Flowers regular, bisexual; calyx more or less deeply 4-5-cleft; corolla 4-5-loked; stamens 4-5, opposite the corolla-lobes; ovary 1celled, with free central placenta, and (in Samolus) half-inferior; style 1 ; seeds albuminous; herbs

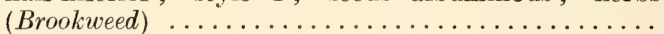

B. Order Plumbaginales. Flowers regular, bisexual ; calyx tubular, 5-toothed; petals 5, united at least at the base ; stamens 5, opposite the petals; ovary 1-celled, with 5 styles, 1-ovuled; seeds albuminous; herbs

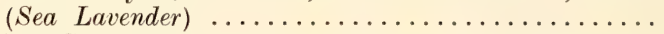

B. Order Contortae. Flowers regular; calyx-lobes and corolla-lobes usually 5 , the latter twisted in bud; stamens 5 or fewer ; ovary 1-2-celled or of distinct carpels ; leaves simple, usually opposite, without stipules.

C. Carpels completely united in a 1-2-celled ovary ; stigmas 2 ; flowers regular, bisexual.

D. Stamens 2, inserted in the corolla-tube but not opposite the lobes; calyx and corolla 4-6-lobed; ovary 2 -celled, with 1 style; capsule, berry, or drupe; leaves usually opposite; shrubs (Jasmine)

D. Stamens as many as corolla-lobes, alternate with them, and inserted on the tube ; seeds albuminous.

Calyx 2-5-lobed; corolla 4-5-lobed; ovary 2-celled; style simple or 2-branched; capsule; leaves

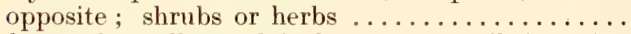

Calyx and corolla 4-5-lobed; ovary 1-celled, with 2 parietal placentas, or completely 2 -celled, with 1 style : capsule ; leaves opposite or radical ; herbs, sometimes aquatic (Centaury) ...............

C. Ovary of 2 distinct carpels, with 1 united style and stigma; flowers regular and bisexual; calyx and corolla 5-lobed; ovules pendulous, several in each carpel ; stamens 5, alternate with the corolla-lobes; seeds albuminous ; leaves mostly opposite ; branches usually with milky juice.

Stamens free, inserted on the corolla-tube; pollen powdery; fruit of 1 or 2 drupes or follicles; shrubs or perennial herbs (Periwinkle Family) ...........

Stamens connate in a tube round the style, the filaments bearing 5 appendages called the corona; pollen consolidated into pendulous masses; fruit of 1 or 2 follicles; seeds usually hair-tufted; shrubs or twining herbs (in Sarcostemma leafless) ...........

B. Order Tubiflorae. Flowers bisexual, regular or irregular, and in the latter case the corolla is 2-lipped; corolla tubular in the lower part, with the stamens inserted upon it.

E. Flowers regular, the limb of the corolla usually spreading horizontally; stamens as many as corolla-lobes.

F. Fruit separating into 4, rarely 2, 1-seeded nutlets; calyx and corolla 4-lobed; stamens 5, opposite the corolla-lobes; ovary 2-celled or spuriously 4celled, with 1-2 ovules in each cell; style 1, simple or branched; herbs, usually rough-hairy, with alternate simple leaves (Heliotrope, Forget-me-not,

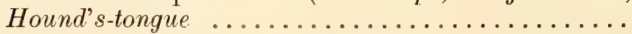

F. Fruit a berry or capsule; stamens 5, on the corollatube and alternate with the lobes.

Fruit a capsule ; calyx of 5 sepals or 5 -lobed : corolla 5 -angled or 5-lobed; ovary usually 2 -celled, or (in Dichondra) of 2 separate carpels, with 1-2 basal ovules in each cell; styles 1 or 2 ; herbs, often twining, with alternate leaves, or (in Cuscuta) a leafless parasite (Bindweed, Dodder) ..........

Epacridaceae 87.

Primulaceae 88.

Plumbaginaceae 89

Oleaceae 90.

LOGANIACEAE 91.

Gentianaceae 92.

Apocynaceae 93.

Asclepiadaceae 94.

Borraginaceae 96.

C'onvotivulaceae 95 
Fruit a berry or capsule; calyx and corolla 4-5lobed; stamens 4-5; ovary 2-celled or spuriously 4-celled, with several ovules on septal placentas; style 1 ; leaves alternate; shrubs or herbs ( Nightshade, Tobacco, Boxthorn, Pituri) ...........

E. Flowers irregular (almost regular in Myoporum, Ruellia, and some Verbenaceae); style 1.

G. Ovary-cells with many or with 2 superposed ovules calyx more or less deeply cleft into 5 lobes or sepals, rarely fewer; corolla more or less 2-lipped, 5lobed; fruit usually a capsule.

H. Ovary 2-celled; placentas septal; herbs or shrubs.

Cells many-ovuled, rarely 1-ovuled (calyx reduced to 2 sepals in Dischisma): stamens 2 , or 4 in pairs, rarely 5 ; seeds albuminous; leaves alternate or opposite (Snapdragon Family)....

Cells many-ovuled; stamens 4 in pairs; capsule long, 2-valved; leaves opposite, pinnate; seeds without albumen $($ Tecoma $) \ldots \ldots \ldots \ldots \ldots$. . . .

Cells with 2 or more superposed ovules; corolla sometimes almost regular; stamens 2, or 4 in pairs ; seeds without albumen ; leaves opposite

H. Ovary 2-4-celled, with 1-several pendulous ovules in each cell ; corolla sometimes almost regular ; stamens 4.5 ; fruit sometimes a drupe; shrubs

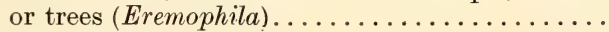

H. Ovary 1-celled.

Parasitic herbs with scale-like leaves; calyx apparently reduced to 2 or 4 segments or sepals ; stamens 4 in pairs; ovary with 4 protruding parietal placentas bearing many ovules (Broomrape) $\ldots \ldots \ldots \ldots \ldots \ldots \ldots \ldots \ldots \ldots \ldots \ldots \ldots \ldots \ldots \ldots \ldots \ldots \ldots$

Aquatic herbs with radical leaves; calyx 2 -4-cleft ; stamens 2; anthers 1-celled; ovary with several ovules on a free central placenta (Bladder-

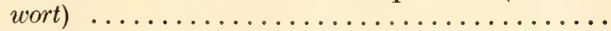

G. Ovary 4-celled, with only 1 ovule in each cell (1-celled with 4 ovules in Avicennia); leaves opposite or whorled.

I. Style basal between the 4 cells of the ovary ; calyx 5 -toothed or 2-lipped; stamens 2 , or 4 in pairs ; fruit separating into 4 nutlets ; herbs or undershrubs, with usually 4 -angled branches (Sage,

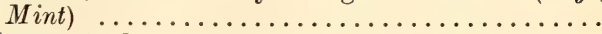

I. Style terminal on the summit of the ovary.

Calyx 4-5-toothed or 4-5-partite; corolla 2lipped or sometimes regular; stamens 4-5; fruit a drupe, capsule, or separating into 4 nuts ; herbs or shrubs (Verbena, Mangrove).. Calyx 5-partite; stamens 4 in pairs; fruit a

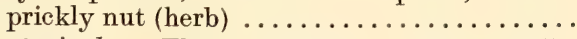

B. Order Plantaginales. Flowers regular; sepals, corollalobes and stamens 4 ; ovary 2-4-celled, with 1-several ovules in each cell; style 1 ; capsule circumsciss ;

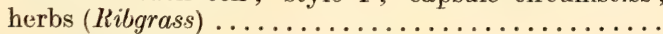

A. Ovary inferior (except in Brunoniaceae) ; calyx and corolla epigynous; stamens epigynous or perigynous.

J. Stamens free.

Order Rubiales. Ovary 1-several-celled, with 1-many anatropous ovules in each cell.

K. Stamens equalling the corolla-lobes in number (except in some Rubiaceae), inserted on the corolla-tube and alternate with the lobes; flowers regular.

Stipules present, sometimes resembling the true leaves ; calyx 3-6-toothed or almost obsolete; corolla 3-5-lobed; ovary 1-4-celled, with 1 or more ovules in each cell; style 1; nut, drupe, or capsule, the capsules sometimes connate; leaves opposite or whorled; herbs or shrubs ................

MYOPORACEAE 106.

Orobanchaceae 103.

Lentibulariaceae 104.

Labiatae 98.

VERbenaceae 97.

Pedaliaceae 102.

Plantaginaceae 107.

Rubiaceae 108. 
Stipules absent; sepals 4-5; corolla rotate, 4-5-lobed; ovary 3-5-celled, with 1 pendulous ovule in each cell ; stigmas 3-5, sessile ; berry ; leaves opposite, pinnate; small trees or shrubs (Elder) .........

K. Stamens fewer than the corolla-lobes; ovary with 1 fertile cell and 1 pendulous ovule; flowers irregular; herbs with opposite leaves; style 1.

Ovary 3-celled, but 2 cells abort and only 1 produces a seed; sepals 5 , or scarcely apparent; corolla with 5 , sometimes almost equal spreading

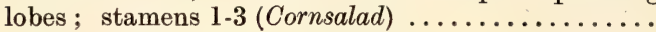

Ovary 1-celled; calyx 5-toothed, united at base with the ovary and with a ribbed outer calyx or involucel ; corolla 5-lobed; stamens 4; fruit indehiscent; flowers in a head (Purple Pincushion) .............

J. Stamens connivent round the style or united by their anthers.

L. Order Cucurbitales. Flowers regular, unisexual ; calyx 5-toothed; corolla 5-lobed; stamens 5, at the base of the corolla-tube, but apparently 3, 1 of them with a single anther and the 2 others with 2 united anthers each ; ovary 3 -celled, usually with numerous ovules on apparently parietal placentas; fruit a berry, often with a hard rind; herbs, often climbing

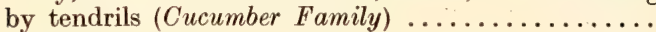

L. Order Campanulatae. Anthers connivent or united; style 1 .

M. Style with 2-5 stigmas; flowers bisexual, regular or irregular; sepals usually $\mathbf{5}$; corolla usually $\mathbf{5}$. lobed, slit on one side in some genera; stamens on corolla-tube and alternate with the lobes; ovary 2-5-celled with many ovules in each cell; capsule, rarely a berry ; seeds albuminous ; herbs

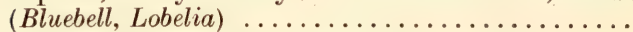

M. Style with a cup-shaped or 2-lipped indusium containing the stigma; flowers bisexual.

Flowers irregular; sepals 5 ; corolla with 5 winged lobes, the tube slit open on one side ; anthers 5 ; ovary 1-2-celled, more or less inferior; capsule, drupe or nut; seeds albuminous; herbs

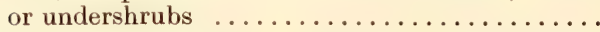

Flowers almost regular, in heads; calyx 5-lobed; corolla eylindrical, with 5 nearly equal lobes, hypogynous ; anthers 5, united ; ovary superior, 1-celled; nut; seed exalbuminous ; herb (Blue

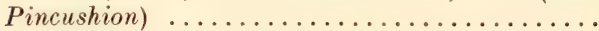

M. Style connate with the filaments in a usually irritable column; flowers irregular, bisexual; sepals 5 ; corolla 5-lobed, the 5th lobe minute; stamens 2 ; ovary 1-2-celled; capsule; seeds albu-

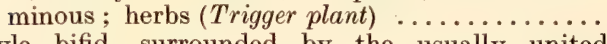

M. Style bifid, surrounded by the usually united a nthers; flowers regular or irregular, bisexual orunisexual, in head surrounded by an involucre of bracts ; calyx represented by bristles, spines, or scales (pappus) ; corolla 4-5-toothed; stamens 4-5, on the corolla-tube; ovary 1-celled, 1 ovuled; achene; seeds exalbuminous; herbs or shrubs (Daisy, Aster, Everlasting)......... 


\title{
FLORA OF SOUTH AUSTRALIA.
}

\author{
CRYPTOGAMS.
}

This well-known term covers conveniently a number of Divisions in Engler's classification dealing with plants which have no real flowers and whose most visible means of reproduction are spores or reproductive cells. Cryptogams which are composed only of cellular tissue include Algae (Seaweeds, \&c.), Fungi (Mushrooms, \&c.), Bryophyta (Mosses and Liverworts), and Characeae (Stoneworts), all of which lie outside the scope of this flora. Only the Vascular Cryptogams are here dealt with.

\section{DIVISION 1.-PTERIDOPHYTA.}

Plants without flowers, but with closed vascular bundles in the stems and leaves; reproduction effected by spores in the asexual generation (which is the conspicuous plant). From the spore is developed a minute growth (the prothallus), which bears archegonia (female organs) and antheridia (male organs) and is, therefore, the sexual generation (the gametophyte); the fertilisation of the egg produced in the former by a sperm freed from the latter results in an oospore (zygote) which develops into the asexual plant. The asexual or embryonal generation (the sporophyte) is the only one here described.

\section{Class FILICALES.}

Fructification consisting of small spore-cases (sporangia), arranged on the under surface of the fertile leaves in clusters called snri, which are sometimes covered, when young, by a thin membrane called the indusium, or by the recurved border of the leaf ; spores very minute, numerous in each spore-case. Perennial plants, sometimes arborescent; leaves radical or alternate, usually rolled inwards like the head of a crozier before their development and the petiole more or less covered with membraneous scales.

\section{FAMILY 1-CYATHEACEAE.}

Spore-cases with a complete oblique ring and usually with an indusium. Tree ferns, with divided leaves.

\section{DICKSONIA, L' Hér.}

(After James Dickson, an English cryptogamic botanist).

1. D. antaretica, Labill. (1810). An arborescent fern with long rigid leaves twice or thrice pinnatisect; sori marginal on the concave lobes of the pinnules; indusium globular, about $1 \mathrm{~mm}$. diam. D. Billardieri, F. v. M. (1874).

Recorded by Bentham for "Mount Gambier, F. Mueller; Lofty Ranges, Heyne." Already in 1890 Tate wrote (Fl. 201), "Here probably extinct." I have seen no specimen. Mueller's statement, published in 1874 (Fragm. viii., 175), is that a few specimens had been found "at the waterfalls of Mount Lofty" by E. B. Heyne.

\section{FAMILY 2.-POLYPODIACEAE.}

Spore-cases with an incomplete longitudinal ring, stalked and numerous in sori on the under surface or margin of the leaves, with or without an indusium. Ferns.

A. Sori marginal.

B. Sori covered by an indusium at least when young.

C. Indusium opening outwards (towards the margin). . Lindsaya 1.

C. Indusium opening inwards (towards the midrib).

D. Sori short.

Pinnules stalked

Adiantum 2.

Pinnules sessile $\ldots \ldots \ldots \ldots \ldots \ldots \ldots \ldots \ldots \ldots$ ChemLanthes 3.

D. Sori long and usually continuous.

Indusium single.

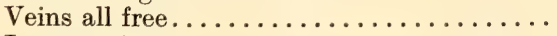

Lower veins anastomosing $\ldots \ldots \ldots \ldots \ldots$

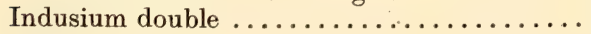

B. Sori without indusium $\ldots \ldots$

A. Sori distant from the margin, or covering the undersurface.

E. Indusium present.

F. Sori long, linear or oblong.

Sori on both sides of the midrib........

Sori on nerves diverging from midrib .... 
F. Sori and indusia more or less rounded.

Indusium orbicular, attached to the leaf by a short central stalk ................

Indusium reniform, attached laterally to the

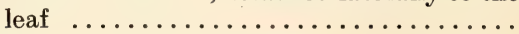

E. Indusium absent; sori linear.

Sori covering most of the veins $\ldots \ldots \ldots \ldots \ldots$

Sori laterally attached to the veins ........

\section{Polystichum 10.}

DRYOPTERIS 11.

Gymnogramme 12.

Pleurosorus 13.

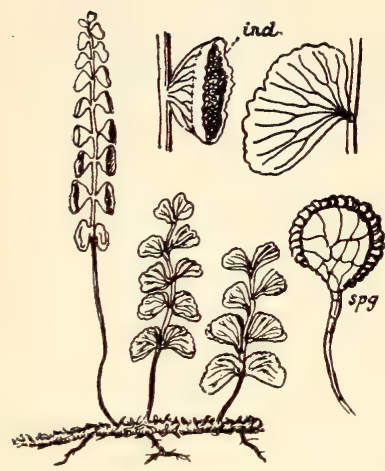

FIG. 3.-Lindsaya linearis.

\section{LINDSAYA, Dryand.}

(After John Lindsay, a surgeon in Jamaica.)

1. L. linearis, Swartz. A small fern; rhachis of leaves wiry, shining, dark reddish-brown; leaves simply pinnate; pinnae small, obliquely fan-shaped, distant, with forked veins; sori in a continuous line along the outer margin of the pinna, with a broad marginal indusium splitting down the middle and presenting a cup-like appearance.

Moist parts of the State; usually in peaty soil.

\section{ADIANTUM, L.}

(Greek adiantos, dry; the leaves remain dry when dipped into water.)

1. A. aethiopicum, L. Maidenhair. Leaves rather large, 2-3-pinnate; petiole and rhachis dark, shining, wiry ; pinnules (or ultimate segments) on short capillary petiolules, suborbicular, thin, with forked veins; sori distinct in the sinus of the crenatures of the pinnule, covered by the marginal reniform indusium.

Mount Lofty Ranges and moist parts of the State.

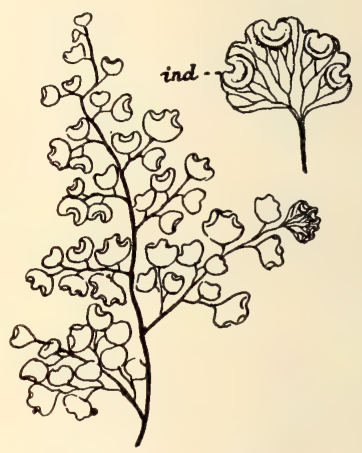

FIG. 4.-Adiantum aethiopicum.

\section{CHEILANTHES, Swartz.}

(Greek kheilos, a lip ; anthos, flower ; alluding to the lip-like indusi.um)

Sori globular or finally confluent, forming an interrupted marginal line, partly covered by recurved indusium which is a continuation of the margin of the sessile pinnules; petiole and leaf-rhachis dark glossy-brown; veins forked-from a central nerve, bearing the marginal sori at their ends.

Leaves 3-pinnatisect in lower part; indusium interrupted Ch. tenuifolia 1.

Leaves 2-pinnate; indusium continuous.............. Ch. Clelandii 2.

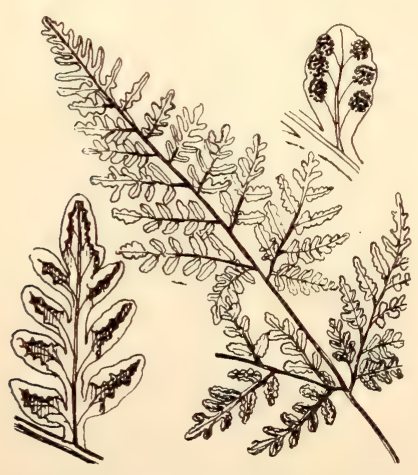

FIG. 5.-Cheilanthes tenuifolia.

1. Ch. tenuifolia, Swartz. Leaves lanceolate in outline, imperfectly tripinnatisect in the lower part, the secondary segments lanceolate, pinnatifid to pinnatisect, rather thin; petiole glabrous or somewhat scaly; sori and indusium interrupted in the sinus of the lobes of the pinnules.

All over the State.

2. Ch. Clelandii, F. v. M. et Tate. Leaves bipinnate, the segments broadly linear, minutely crenulate-serrate; rhachis beset with very short somewhat glandular hairs; indusium broad and continuous along the margin of the segments, sori minute, each separately lodged in a sinus of the serrature ; "indusium of a Pteris."

Caroona Hill, Gawler Ranges. There is no specimen in the Tate Herbarium, and I merely condense the original discription, published in 1887 . 


\section{PTERIS, L.}

(Greek pteris, a fern.)

1. Pt. tremula, R. Br. Leaves tall, broadly lanceolate in outline, 3-4-pinnate in the lower part; ultimate pinnules or segments broad-linear, thin in texture, somewhat decurrent; sori marginal, continuous or interrupted, at the ends of branched free veins springing from the midrib and more or less concealed by the indusium, which opens along its inner side.-Pt. arguta, F. v. M., not of Ait.

Below cliffs along River Murray, in Hundred of Younghusband; Streaky Bay; near Glencoe, S.E.

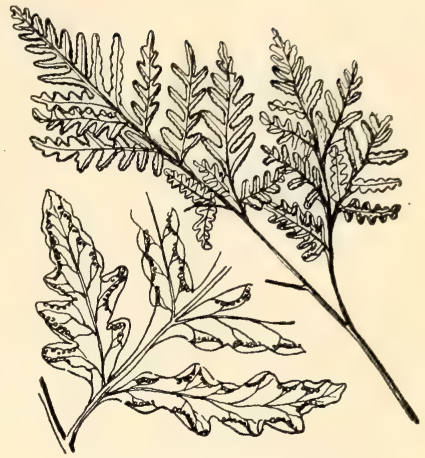

FIG. 6.-Pteris tremula.

5. HISTIOPTERIS, J. Smith.

(Greek histion, tissue ; pteris, a fern.)

1. H. incisa, (Thunb.), J. Smith. Leaves large and broad, 2-3-pinnate ; ultimate segments deeply pinnatifid with broad rounded lobes, the veins repeatedly forked and sometimes anastomosing . sori continuous, with an indusium as in Pteris.-Pteris incisa, Thunb.

Penola (South-East).

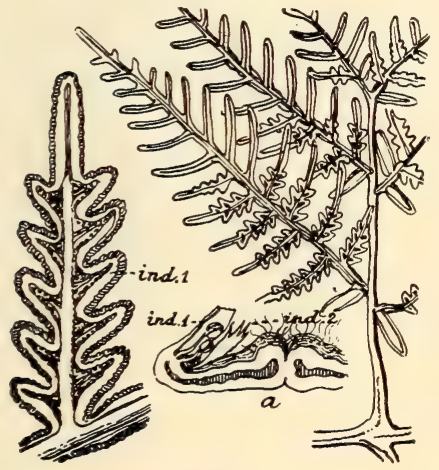

FIG. 7.-Pteridium aquilinum.

\section{PTERIDIUM, Gleditsch.}

(Name formed from Pteris.)

1. Pt. aquilinum, (L.), Kuhn. Bracken. Leaves large, rigid, triangular in outline, 3-4-pinnate at base, the ultimate segments decurrent at base and hairy below, the upper ones of each pinnule linear and entire and the terminal one long; sori continuous along the thickened margin, covered by the marginal indusium which opens on the inner side, and also by a very delicate inner indusium. -Pteris aquilina, L.

Mount Lofty Range; common in the SouthEast and other southerly parts of the State. Cosmopolitan.

\section{NOTHOLAENA, R. Br.}

(Greek nothos, spurious ; laina, a cloak; on account of the curved margin of the leafsegments forming a spurious indusium.)

Sori marginal as in Cheilanthes, but the margin is unchanged and very slightly recurved.

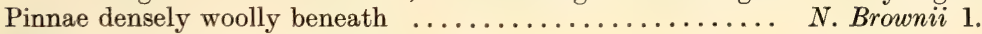
Pinnae with scaly hairs beneath $\ldots \ldots \ldots \ldots \ldots \ldots \ldots \ldots \ldots$ distans 2.

1. N. Brownii, Desv. Usually a small fern; leaves bipinnatisect, the rhachis covered with reddish hairs and scales; pinnae broadly lanceolate, pinnatifid, green and villous above, densely woolly with reddish hairs below ; the segments obtuse and the lower ones lobed. $-N$. vellea, R. Br. not of Desv. Cheilanthes vellea, F. v. M.

Flinders Range; Musgrave Ranges and Far North.

2. N. distans, R. Br. Resembles the preceding, but the leaves are less hairy and sometimes glabrous above, while the hairs of the undersurface are scale-like and not nearly so dense.-Cheilanthes distans, A. Braun.

Mount Lofty Range and as far north as the Gawler Ranges.

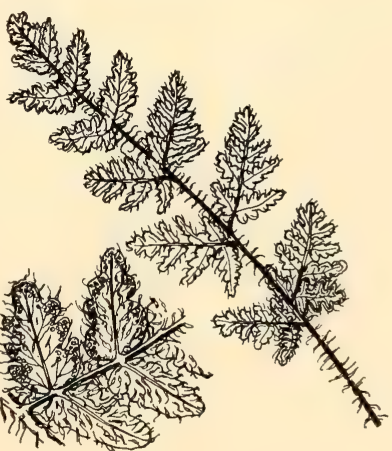

FIG. 8.-Notholaena distans. 


\section{BLECHNUM, L.}

(Greek blekhnon, the name of a fern.)

Leaves pinnate or pinnatisect, dissimilar; the barren ones spreading, the fertile ones erect, with much narrower pinnules; veins forked; sori in 2 continuous lines parallel to the midrib of the pinnae, the indusium opening from the midrib outwards.

A. Segments of barren leaves attached to the rhachis by a broad base.

Barren segments long $\ldots \ldots \ldots \ldots \ldots \ldots \ldots \ldots \ldots$ B. discolor 1.

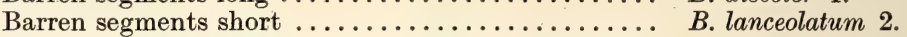

A. Segments mostly attached to the rhachis by the midrib

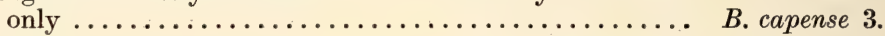

1. B. discolor (Willd.) Keys. Barren leaves lanceolate in outline, paler below, pin. natisect, the longer segments $5-8 \mathrm{~cm}$. long, narrow-lanceolate, confluent at base, the lower ones smaller; fertile segments narrower and rather shorter, with a dark rhachis.-Lomaria discolor, Willd.

Mount Lofty Ranges.

2. B. lanceolatum (R. Br.), Sturm. Resembles the preceding, but the segments of the barren leaves are shorter (the longest $2-4 \mathrm{~cm}$. long) and the lowest are very short and broad.-Lomaria lanceolata, Spreng.

Given for Mount Gambier on the authority of Mueller (Fl. Aust., vii., 736), but I have not seen any specimens from this State.

3. B. capense (L.), Schlecht. Leaves pinnate in the greater part, pinnatisect near the summit, the majority of the lanceolate pinnae or segments with an obliquely truncate base and attached to the rhachis onlv by the midrib, a few of the uppermost attached to the rhachis by the lower half of the broad base, the longest $5-15 \mathrm{~cm}$. long, $1 \frac{1}{2}-2 \mathrm{~cm}$. broad, serrulate, all lighter green below; fertile eaves similar, but the pinnae usually much narrower, the under-surface sometmes covered entirely by the sori, and the rhachis more or less scaly.Lomaria capensis, Willd.

Mount Lofty Range; Kangaroo Island; SouthEast. The adnate character of the upper segments brings our specimens very near to $B$. cartilagineum, Swartz, a species of Eastern Australia.

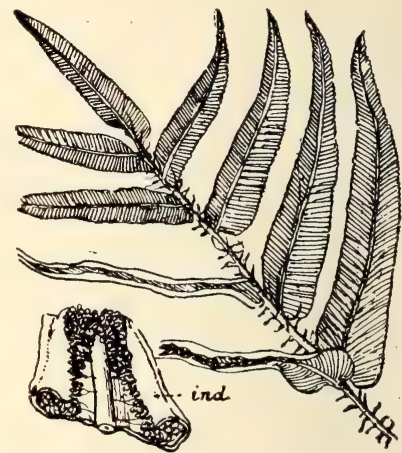

FIG. 9.-Blechnum capense.

\section{ASPLENIUM, L.}

(Greek asplenon, name of a fern considered to be a cure for diseases of the spleen ; from $a$, without ; splèn, spleen.)

Sori linear or oblong, on forked veins proceeding obliquely from the midrib ; indusium attached lengthwise to the vein and opening towards the midrib.

A. Leaves simply pinnate.

Pinnae fanshaped; rhachis mostly green.......... A. flabellifolium 1.

Pinnae ovate ; rhachis black ................. Trichomanes 2.

A. Leaves twice pinnatisect.

Ultimate segments lanceolate,

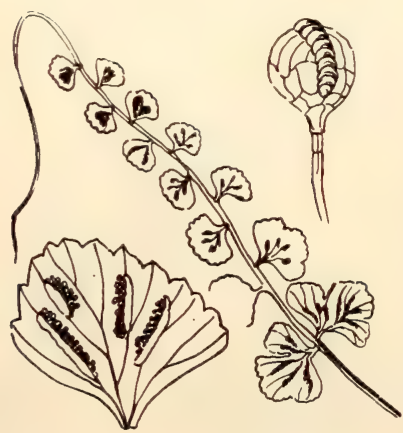

FIG. 10.-Asplenium flabellifolium. pinnatifid .................

Ultimate segments oblong,

toothed ............... A. praemorsum 4.

1. A. flabellifolium, Cav. Fan-leaved Spleenwort A small delicate fern; leaves once pinnate, with fan. shaped pinnae 5-15 $\mathrm{mm}$. broad, crenately toothed; petiole bl ck and shining, most of the rhachis green: sori confluent when old.

Common in the Mount Lofty and Flinders Ranges and in the other moist districts.

2. A. Trichomanes, $L$. Common Spleenwort. Also a small, tufted fern; pinnae ovate or obovate 4-8 $\mathrm{mm}$. long, crenately toothed; both petiole and rhachis black and shining.

Mount Gambier district. Widely spread throughout the temperate parts of the world. 
3. A. bulbiferum, Forst. Leaves large, bipinnatisect, often proliferous; ultimate segments lanceolate, 1-2 cm. long, deeply pinnatifid, with 1 forked vein to each lobe; sori large, 1 to each lobe, the indusium opening away from the vein towards the midrib of the segment.

South-East.

4. A. praemorsum, Swartz. Leaves bipinnatisect, slightly scaly; ultimate segments coriaceous, coarsely toothed, striate owing to the prominent veins.-A furcatum, Thunb.

South-East.

\section{POLYSTICHUM, Roth.}

(Greek polys, many ; stichos, a row ; alluding to the many rows of sori.)

1. P. aculeatum (L.). Schott. Leaves large, bipinnatisect, rhachis very scaly ; primary segments lanceolate, acute ; ultimate segments ovate-lanceolate, prickly-toothed, enlarged on the upper margin into a prominent lobe ; veins forked, free, diverging from the midrib ; sori in 2 rows between the midrib and the margin of the segment; indusium orbicular, affixed peltately by its centre.-Aspidium aculeatum, Swartz.

South-East. Almost cosmopolitan.

\section{DRYOPTERIS, Adans.}

(Greek drys, an oak ; pteris, a fern : alluding to the leaves of some species.)

Leaves more or less compound; veins free or the lower ones meeting; sori orbicular, covered by small heart-shaped or kidney-shaped indusia, which are fixed to the leaf by the centre of the notch ; indusium falling off early or sometimes wanting.

A. Leaves simply pinnate $\ldots \ldots \ldots \ldots \ldots \ldots \ldots \ldots \ldots$ D. parasitica 1 .

A. Leaves twice or thrice pinnatisect.

Ultimate segments acutely toothed, thin and flaccid .. D. decomposita 2.

Ultimate segments crenately toothed, stiff ......... D. punctata 3.

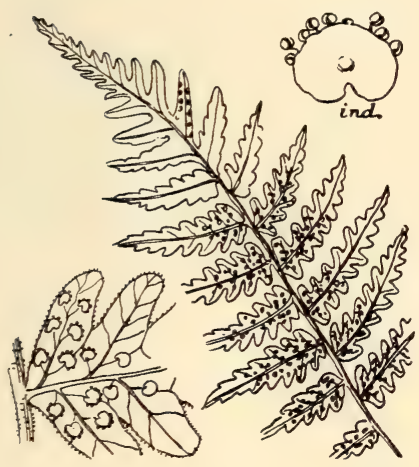

FIc. 11.-Dryopteris parasitica.

1. D. parasitica (L.), O. Kuntze. Leaves once pinnate, the rhachis glabrous or pubescent; pinnae lanceolate, truncate at base, the lower ones gradually smaller; lobes oblong, obtuse, curved upwards, the lowest veins of adjoining lobes united into one vein which extends to the sinus; sori in the middle of the veins and extending in 2 rows parallel to the midrib of the lobes.-Aspidium molle, Swartz.

Below cliffs on River Mu ray at Caurnamont and in Hundred of Younghusband; rock holes at Nilcurloo, E.P.

D. gongylodes (Schkuhr), O. Kuntze (Aspidium unitum, Swartz), was found by Professor Tate in the ( therefore occur in our Far North. It differs from D. parasitica in the lower pinnae as long as the others, the lobes broader, shorter and acute, and in the sori forming 1 row along the margin of the lobes.

2. D. decomposita ( $\mathrm{R} . \mathrm{Br}$ ), $\mathrm{O}$. Kuntze. Leaves bipinnatisect or the larger ones tripinnatisect, dark green, the rhachis usually pubescent; pinnae lanceolate, acute, pinnatisect towards base; segments acutely toothed; sori about halfway between the midrib and the margin of the segments or lobes of the pinna.-Aspidium decompositum, Spring.

Yallum Caves (South-East).

3. D. punctata (Thunb), C. Chr. Leaves twice or thrice pinnatisect, sometimes very large, the rhachis usually glandular-hairy: lower pinnae often $30 \mathrm{~cm}$. long or more ; secondary segments lobed or deeply pinnatifid, rigid when in fruit, the lobes or ultimate segments toothed, obtuse; sori in 2 rows on the segments or lobes, about halfway between the midrib and margin.-Polypodium punctatum, Thunb.

Mount Lofty Range; Glencoe, near Mount Gambier.

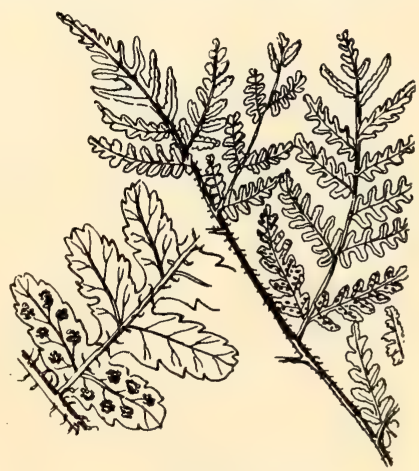

FIG. 12,-Dryopteris punctata. 
12. GYMNOGRAMME, Desv.

(Greek gymnos, naked; gramma, a writing : alluding to the naked sori affixed to the veins in lines.)

Leaves pinnate or bipinnatisect, with the veins free and repeatedly forked; sori affixed along the centre of the terminal veins and covering them, sometimes appearing marginal ; no indusium.

Leaves simply pinnate, scaly $\ldots \ldots \ldots \ldots \ldots \ldots \ldots \ldots \ldots$ G. Reynoldsii 1.

Leaves bipinnatisect, glabrous.................... leptophylla 2.

1. G. Reynoldsii, F. v. M. (under Notholaena and Grammitis). Small perennial ; leaves once pinnate, with a wiry black shining scaly rhachis; pinnae ovate or oblong, entire, thick, opposite, 1-2 cm. long, more or less clothed on both faces with scaly linearlanceolate toothed hairs, the clothing denser on the under-surface; the 3 terminal pinnae united into one 3 -lobed pinna; sori on the terminal veins, almost concealed by the hairs, finally confluent and forming a broad marginal line.

Parachilna Gorge (Flinders Range); Mount Ilbillie (Everard Range); near Mount Watson and Birksgate Range; usually among granite boulders.

2. G. leptophylla (L.), Desv. Delicate little glabrous annual or biennial; leaves bipinnatisect, the outer ones shorter with a few fan-shaped pinnae, the ultimate segments obovate-cuneate, more or less deeply lobed; the sori finally almost covering the undersurface of each lobe.-Grammatis leptophylla, Swartz: Anogramme leptophylla, Link.

Mount Lofty and Flinders Ranges. Widely spread throughout the world.

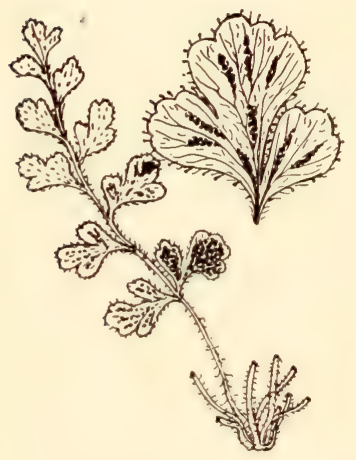

\section{PLEUROSORUS, Fée.}

(Greek pleura, side ; soros, a heap: alluding to the position of the sori along the sides of the veins.)

1. P. rutifolius (R. Br.), Fée. Small perennial fern, more or less beset with long scaly hairs or shorter glandular hairs; leaves simply pinnate; pinnae fan-shaped or obliquely obovate; veins radiating from the base of the pinna, repeatedly forked; sori linear, attached to the side of the veins and often covering the whole undersurface; no indusium.-Grammitis rutifolia, R. Br.

Hilly country in most parts of the State.

FIG. 13.-Pleurosorus rutifolius.

\section{FAMILY 3.-GLEICHENIACEAE.}

Spore-cases few (2-8) in the sorus, surrounded by an obscure transverse ring and opening by a longitudinal slit, without an indusium; sori seated on the forked veins.

\section{GLEICHENIA, Sm.}

(After F. W. Gleichen, a German botanist, 1717-1783.)

1. G. circinata, Swartz. Coral Fern; Bird's Nest Fern. Leaves either short and bipinnate, or long and dichotomously branched so as to be 3-4-pinnate; pinnae linear-lanceolate, 2-5 cm. long, spreading, cut to the midrib into numerous small alternate contiguous pinnules or segments, flat, ovate, and about $2 \mathrm{~mm}$. broad in the short barren leaves, almost orbicular, 1-1 $\frac{1}{2} \mathrm{~mm}$. broad, of thicker texture and recurved on the margins in the fertile leaves ; rhachis hairy; sori solitary near the upper basal angle of each segment, consisting of $2-4$ sporecases, and almost concealed by the margin.

Mount Lofty Range; South-East.

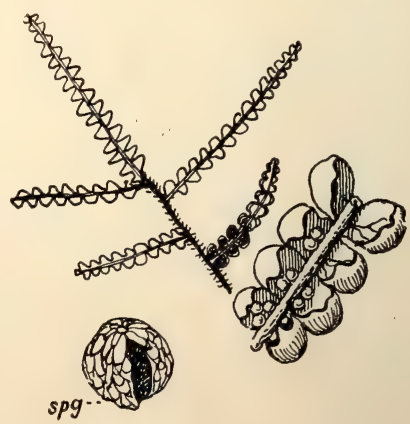

FIG 14 - Gleichenia circinata. 


\section{FAMILY 4.- SCHIZAEACEAE.}

Spore-cases sessile, with a small complete ring at the summit, opening by a longitudinal slit.

(Greek skhizo, I cut; alluding to the contiguous segments of the fertile leaves.)

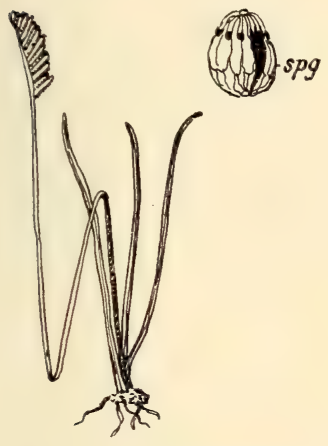

FIG. 15.-Schizaea fistulosa.

\section{SCHIZAEA Sm.}

1. Sch. fistulosa, Labill. Comb Fern. A small fern about $15 \mathrm{~cm}$. high, with slender usually undivided wiry leaves, the sterile ones without any lamina, the fertile ones longer and bearing at the summit 6-20 pairs of closely contiguous linear fringed segments, 3-5 $\mathrm{mm}$. long; spore-cases in 2 rows covering the inner surface of the segments and in 5-10 pairs.

Peaty soil at Square Waterhole; Clarendon. A specimen from Mount Compass has the leaf once forked below the middle, which brings it near to Sch. bifida, Swartz, but in other respects it agrees with Sch. fistulosa.

\section{FAMILY 5.-OSMUNDACEAE.}

Spore-cases with short thick stalks and a unilateral group of thickened cells at the summit, opening by a longitudinal slit; ferns with thick trunks.

\section{TODEA, Willd.}

(After H. J. Tode, a German cryptogamic botanist.)

1. T. barbara (L.), T. Moore. King Fern. Trunk thick, often more than $1 \mathrm{~m}$. high; leaves to $2 \mathrm{~m}$. long, bipinnatisect; pinnae numerous; ultimate segments numerous, lanceolate, serrate, the upper ones confluent at base ; sori crowded on the forked veins of the lower segments of the lower pinnae, finally covering the undersurface.-Osmunda barbara, Thunb.

Gullies in Mount Lofty Range.

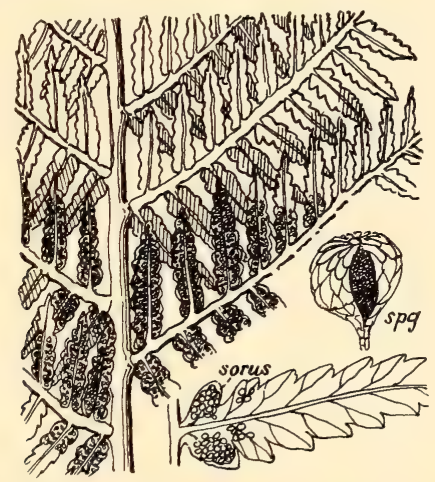

FIG. 16.-Todea barbara.

\section{FAMILY 6.-OPHIOGLOSSACEAE.}

Differs from the other fern families in the young leaves not rolled inwards at the summit in the shap 2 of a crozier; spore-cases comparatively large, marginal, more or less united, without ring or indusium, opening in a slit which is longitudinal as to the spore-case, but transverse to the rhachis of the spike, sessile in 2 rows along the spike-like fertile leaf, which may be simple or branched.

Leaves undivided 


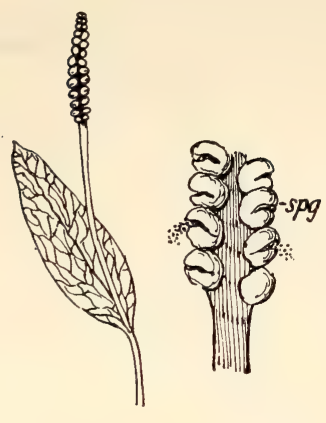

FIG. 17.-Ophioglossum coriaceum.

\section{OPHIOGLOSSUM, L.}

(Greek ophis, a snake; glossa, tongue : alluding to the shape of the fruiting spike.)

1. 0. coriaceum, A. Cunn. Adder's-tongue. Usually a small plant, the barren and fertile leaves combined on a common stem-like petiole; blade of barren leaf rather thick, ovate-lanceolate or oblong-lanceolate, acute, 3-5 $\mathrm{cm}$. long, about $1 \frac{1}{2} \mathrm{~cm}$. broad, midrib usually distinct; petiole of fertile leaf united to the barren leaf either above or below the base of the blade; fruiting spike linear, 15-25 $\mathrm{mm}$. long, with $\mathbf{1 5 - 2 5}$ pairs of spore-cases; spores finely reticulate under microscope.-O vulgatum, Benth. non $\mathrm{L}$.

Throughout the State but not common. Very closely allied to the European $O$. lusitanicum, L.

\section{BOTRYCHIUM, Swartz.}

(Greek botrys, a cluster of grapes : alluding to the arrangement of the spore-cases.)

1. B. australe, $\mathrm{R}$. Br. Barren leaves sheathing the fertile one by the base of the long petiole, broadly triangular, twice or thrice pinnatisect with 3 broad pinnae, the secondary pinnae lobed at the summit, pinnatisect lower down; ultimate segments not so broad as to overlap each other ; fertile leaf bearing globular spore-cases in 2 rows along its narrow segments.-B. ternatum, Benth. not of Swartz.

This species is only known in South Australia by a barren leaf collected in 1883 near Clarendon (Mount Lofty Range), and preserved in the Tate Herbarium.

\section{FAMILY 7.-MARSILIACEAE.}

The embryonal (asexual) generation is heterosporous, i.e., the spores are of 2 kinds: macrospores, also known as megaspores, producing female prothalli, and microspores, producing male prothalli, both kinds of spore enclosed in separate spore-cases (macrosporangia and microsporangia), the former containing only 1 macrospore and the latter containing numerous microspores. (All the preceding families of Filicales are homosporous, i.e., the spores are of one kind, producing monoecious prothalli.) Fertile leaves shorter than the barren ones, the lamina recurved and united at the margin, so as to form a sporocarp containing sori enclosed in membranous indusia; each sorus consisting of macrosporangia and microsporangia; barren leaves on long stalks; perennial plants.

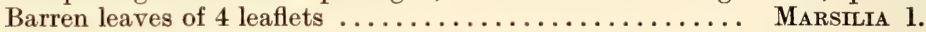

Barren leaves filiform $\ldots \ldots \ldots \ldots \ldots \ldots \ldots \ldots \ldots \ldots$ Pilularia 2.

\section{MARSILIA, L}

(After L. F. Marsigli, an Italian naturalist whose name was Latinised as Marsilius; died 1730.)

Sporocarp ovoid, hard, compressed, opening in 2 valves; barren leaves with a long petiole and a lamina divided into 4 obovate leaflets; rootstock creeping and rooting at the nodes, usually in or near water.

A. Sporocarp stalked.

B. Plant glabrous ..................................... 1

B. Plant hairy.

Fruit smooth ....................... Drummondii 2.

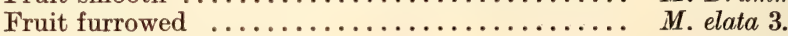

A. Sporocarp sessile or almost so ............... Mirsuta 4.

1. M. Brownii, A. Br. Whole plant glabrous; leaflets obovate, almost entire ; sporo. carps usually in clusters of $\mathbf{2 - 4}$, their stalks united at base but almost free from the petiole of the barren leaf.-M. quadrifolia, Benth. not of $\mathrm{L}$.

River Murray; Flinders Range.

2. M. Drummondii, A. Br. Nardoo. Leaflets silky-hairy or becoming glabrous with age, obovate-cuneate, crenate, or entire, varying in size ; sporocarps 5-9 mm. long, hairy, smooth, the stalks or petioles free at the base and 2-4 times as long as the sporocarps.

River Murray and at least as far south as Bordertown; throughout the Far North and North-West.

3. M. elata, var. crenata, A. Br. Leaves very woolly at base ; leaflets large, crenate, silky; sporocarps about $10 \mathrm{~mm}$. long, hairy, irregularly furrowed, erect on a stalk up to 8 times as long as they.

Near Marree. I have not been able to identify successfully with our specimens most of the numerous species created by A. Braun, but this one appears to be well distinguished. 
4. M. hirsuta, R. Br. Leaflets obovate-oblong, usually small, hairy when young, but soon becoming glabrous; sporocarps small, almost globular, smooth, hairy, sessile or nearly so.

Marshy ground, Pinnaroo.

\section{PILULARIA, L.}

(Latin pilula, a pill : alluding to the shape of the fruits.)

1. P. Novae Hollandiae, A. Br. Pillwort. Rootstock creeping under water; barren leaves clustered, filiform, $3-10 \mathrm{~cm}$. long ; sporocarps globular, 3-4 mm. diameter, pubescent, stalked, 4-celled, each cell enclosing male and female spore-cases; fruit-stalk forming a rhaphe along the sporocarp; macrospores not contracted above the middle.- $P$. globu. lifera, Benth. not of $\mathrm{L}$.

Recorded by Tate for his District S (Lake Torrens to Lake Frome); I do not know on what authority.

\section{FAMILY 8.-SALVINIACEAE.}

Spores of 2 kinds, as in Marsiliaceae, but each sporocarp contains spore-cases of one sex only. Small annual floating plants.

\section{AZOLLA, Lamk.}

(Greek $a$, without; zōē, life : because the plants are killed by any drought.)

Sporocarps globular, 1-celled, membranous, usually in pairs at the base of the lower branches, one containing a single macrosporangium and the other containing many pedicellate microsporangia; leaves small, fleshy, sessile, alternate, closely imbricate in 2 rows; stems branching and rooting. Small floating plants, usually collected in masses on the surface of the water.

Stems deltoid in outline, regularly pinnate $\ldots \ldots \ldots \ldots \ldots$. pinnata 1.

Stems obovate in outline ................... filic uloides 2.

1. A. pinnata, R. Br. Rootlets tending to become feathery ; stems pinnate or bipinnate, the leafy branches spreading regularly and becoming shorter towards the summit of the stem or pinna, so as to give it a somewhat deltoid outline ; larger sporocarps reddish.

River Murray, Jan.-May.

2. A. filiculoides, L. var. rubra (R. Br.) Diels. Whole plant reddish, compact; roots simple, stems rounded in outline, the branches shorter and broader than in the preceding.A. rubra, R. Br.

River Murray, Jan.-May.

\section{CLASS LYCOPODIALES.}

The embryonal generation either homosporous (Lycopodiaceae), or heterosporous, with macrosporangia and microsporangia (Selaginellaceae and Isoetaceae); leaves always minute or very narrow.

\section{FAMILY 9.-LYCOPODIACEAE.}

Spore-cases solitary in the axils of the leaves or bracts of a terminal spike, 2-valved ; spores all of one kind. Perennials, with small simple leaves without ligules.

Leaves spirally imbricate along the stems and branches ... Lrcopodium 1.

Leaves radical, linear ....................... PhyLLoglossum 2.

\section{LYCOPODIUM (Rupp.), L。}

(Greek lykos, wolf ; podion, little foot: resemblance of the leaves to claws.)

Spore-cases compressed, often reniform, opening by a transverse slit, singly sessile in the axils of the upper leaves, or of bracts (altered leaves), and forming spikes; leaves small, 1-nerved, densely crowded all round the stem and branches. Clubmoss.

Spikes terminal.

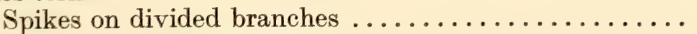

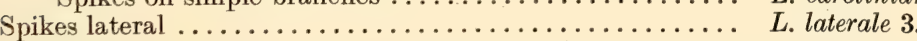

1. L. densum, Labill. Stems creeping underground sending up erect branches which are stemlike in the lower part and dichotomously branched above; leaves lanceolate, those of the stem and lower part of the branch appressed and $3-4 \mathrm{~mm}$. long, those of the branchlets spreading-erect and $2-3 \mathrm{~mm}$. long; fruiting spikes terminal, erect, $1-2 \frac{1}{2} \mathrm{~cm}$. long; bracts ovate-lanceolate with spreading tips.

Near Mount Lofty. 
2. L. carolinianum, L. Stems often subterranean, sending up simple erect fertile branches (sometimes called peduncles); leaves linear-lanceolate, about $3 \mathrm{~mm}$. long, all more or less spreading; spikes terminating the fertile branches ; bracts spreading, ovateacuminate, minutely serrulate.

Peaty swamps about Mount Compass and Square Waterhole.

3. L. laterale, R. Br. Stems often subterranean, with ascending divided branches, which are longer and less rigid than in the 2 preceding species; leaves almost subulate, more or less spreading, 4-6 mm. long; spikes lateral about $1 \mathrm{~cm}$. long; bracts brownish, ovate-acuminate.

Peaty soil at Mount Lofty; Square Waterhole; Kangaroo Island.

\section{PHYLLOGLOSSUM, Kuntze.}

(Greek phyllon, leaf ; glossa, tongue.)

1. Ph. Drummondii, Kunze. Dwarf plant, rising from a tuber produced during the previous year, with 1-3 horizontal roots close to the base of the 1-8 linear radical leaves, which are about $1 \mathrm{~cm}$. long; peduncle about twice as long, bearing a short cylindrical spike; bracts broad, acuminate, shortly exceeding the reniform spore-cases.

Growing in soil which is swampy in winter, National Park, Belair, and other places in the Mount Lofty Range; near Glenelg River, South-East.

\section{Family 10.-SELAGINELLACEAE.}

Spore-cases of 2 kinds (macrosporangia and microsporangia), solitary, sessile in the same spike in the axils of the bracts; macrosporangia containing usually 4 macrospores and opening by 4 valves; microsporangia opening by 2 valves with numerous microspores; spore-cases in terminal spikes; leaves small, arranged in 4 rows, with a minute ligule.

\section{SELAGINELLA, Beauv.}

(Diminutive of Selago, the Latin name of a plant believed to be Lycopodium Selago, the Fir Clubmoss.)

1. S. Preissiana, Spring. A small flaccid annual, with a few erect or ascending stems, simple or forked, $2-7 \mathrm{~cm}$. long, leafy throughout; leaves lanceolate, about $2 \mathrm{~mm}$. long; spikes occupying the greater part of the stem or branches, the leaf-like bracts rather broader than the leaves.

Near marshes and creeks in the Mount Lofty Ranges; Kangaroo Island ; South-East.

S. uliginosa, Spring, has not yet been found in our State, although it grows as near to it as Portland, Victoria. It is distinguished from the preceding by its perennial rhizome, from which arise rigid branches with many distichous lateral branchlets and rigid leaves.

\section{FAMILY 11.-ISOETACEAE.}

Spore-cases brown and almost coriaceous (in our species), of 2 kinds, the macrosporangia solitary at the base of the outer leaves, containing numerous macrospores, the microsporangia solitary, at the base of the inner leaves, containing minute and still more numerous microspores ; the sporangia of many species covered by a membranous velum ; leaves with a minute ligule above the sporangium.

\section{ISOETES, I.}

(Greek isos, alike ; etos, year : because the submerged species remain the same throughout the year.)

1. I. Drummondii, A. Br. Quillwort. Small plant with a short 3-lobed rootstock; leaves radical, filiform, $2-7 \mathrm{~cm}$. long, perforated by 4 longitudinal air-passages, abruptly dilated at base; velum absent; macrospores globular, tuberculate.

In soil which is swampy in winter, but not submerged, National Park, Belair; Teatree Gully; Victor Harbor ; Echunga.

\section{DIVISION 2.-SPERMATOPHYTA.}

The Spermatophytes, or Seedplants (also known as Phanerogams or Flowering Plants) have complete or incomplete flowers, sometimes only consisting of stamens and ovules, and effect reproduction by means of pollen-grains (microspores). These fertilise the egg-cell in the embryo-sac (macrospore), which is in its turn enclosed in the nucellus of the ovule (macrosporangium). The ovule ripens into a seed containing the embryo or young plant. 


\section{SUBDIVISION 1.-GYMNOSPERMS.}

Seeds naked, that is to say, not enclosed in a pericarp, nor is the ovule enclosed in an ovary; hence there is no style or stigma; cotyledons 2 or more. Flowers incomplete, consisting of stamens and ovules, without ovary, style, or floral envelope.

\section{FAMILY 12.- PINACEAE.}

Flowers unisexual, the males in catkins, the females usually in catkins or cones; no real perianth; stamens consisting of scales, each bearing 2 or more anther-cells; female catkins composed of scales, with 1 or several naked ovules within each scale ; fruit a cone, formed of the hardened scales; seeds albuminous, with crustaceous testa; cotyledons 2-15. Comprises several important genera of trees, such as Pinus (the Pine), Abies (the Fir), Cupressus (the Cypress); also the Norfolk Island Pine (Araucaria excelsa) and the Bunya-bunya (A. Bidwillii).

\section{CALLITRIS, Vent.}

(Greek kallos, beautiful ; treis, three; on account of the symmetrical arrangement of the leaves.)

Flowers monoecious; male catkins cylindrical; anther-cells 2-4; female catkins usually of 6 scales arranged in 2 whorls, with several erect ovules within each scale ; fruiting cone consisting of the 6 enlarged and hardened scales (valves) shortly united at the base and apparently arranged in 1 whorl ; seeds compressed, hard, with usually 2 small wings ; cotyledons 2 , rarely 3 ; leaves usually in whorls of 3 , in the young plant free, but soon becoming adherent to, or decurrent on the stem or branch, so that only the scale-like tip of the linear leaf remains free. Resinous trees or shrubs.

A. Cones smooth or slightly wrinkled or warted.

B. Valves without a conical protuberance.

Ripe cones $2 \frac{1}{2}-3 \mathrm{~cm}$. long ................. robusta 1.

Ripe cones scarcely $1 \frac{1}{2} \mathrm{~cm}$. long ............... C. Drummondii 2.

B. Valves with a conical protuberance ............ C. cupressiformis 3 .

A. Cones densely warted ......................... verrucosa 4.

1. C. robusta, R. Br. Murray Pine. Small or large tree with spreading branches and dark-green leaves ; fruiting cones globular or ovoid, $2 \frac{1}{2}-3 \mathrm{~cm}$. long, smooth or slightly wrinkled and sometimes with a few warts on the back of the valves.-C. propinqua, $\mathbf{R}$. Br.

Most parts of the State, August-October.

2. C. Drummondii (Parlat.), Benth. et Hook. Tree or shrub; leaves light-green; fruiting cones globular, under $1 \frac{1}{2} \mathrm{~cm}$. long, smooth and shining, but the valves sometimes bearing a minute protuberance or spur on the back; cones almost tapering into the peduncles, which are often rather long.

Arno Bay, E. P. ; also in Western Australia. Sept.-Dec.

3. C. cupressiformis, Vent. Shrub or small tree, with usually erect branches. Occurs here only in the var. tasmanica, Benth., which has globular cones less than $1 \frac{1}{2} \mathrm{~cm}$. long, the valves usually wrinkled and each provided with a spur surpassing the summit proper; columella 3-lobed (in the other species the columella is a simple 3-sided protuberance rising from the interior base of the cone); leaves dark-green, the branchlets deeply furrowed between them

Gullies near Adelaide; Clarendon; Kangaroo Island. Aug.-Oct.

4. C. verrucosa, R. Br. Shrub inhabiting dry country, sometimes under $2 \mathrm{~m}$. in height; fruiting cones subglobular, slightly over $2 \mathrm{~cm}$. long, densely warted.

Scrub on eastern side of River Murray ; 90-Mile Desert; near Ooldea. Aug.-Oct.

\section{SUBDIVISION 2.-ANGIOSPERMS.}

Plants which have the ovules enclosed in an ovary and later on the seeds enclosed in a seed vessel or pericarp. The pollen-grains (microspores) produced in the anther-cell, are conveyed to the stigma or receptive summit of the ovary, penetrate the stigma and style by means of a pollen-tube, which pushes its way downwards into the cavity of the ovary and enters the ovule usually through the micropyle or small door at its summit. The ovule contains within its coverings the embryo-sac (macrospore). One of the 2 spermatic nuclei which have descended the pollentube fertilises the nucleus of the egg-cell within the embryo-sac, and the egg-cell develops into the embryo or young plant.

\section{CLASS 1.-MONOCOT YLEDONS.}

Plants in which the germinating seed produces only 1 cotyledon or seed-leaf; stems. with closed vascular bundles scattered irregularly throughout the fundamental tissue ; leaves usually with parallel nerves ; parts of the flower usually arranged in whorls of 3 ; radicle soon ceasing to grow and never becoming a taproot. 


\section{FAMILY 13.-TYPHACEAE.}

Flowers monoecious, without perianth, arranged in dense cylindrical spikes, the upper male, the lower female; stamens 2-5, often united towards base ; ovary stalked, with 1 persistant style and unilateral stigma; fruit a small nut with 1 pendulous albuminous seed; testa membranous; radicle superior. Water-plants.

\section{TYPHA, L.}

(Greek typhè, name of the plant.)

1. T. angustifolia, L. Bulrush. Stems erect, reed-like, 1-2 m. high ; leaves long, stiff, $6-8 \mathrm{~mm}$. broad; spikes separated by an interval of about $3 \mathrm{~cm}$., the female one $12-25 \mathrm{~cm}$. long and finally over $2 \mathrm{~cm}$. thick, velvety owing to the tufts of long hairs growing on the slender stalk of the fusiform fruit; anthers 2-3, inserted on a common filament.

T. Muelleri, Rohrb, and T. Basedowii, Graebn. (the latter from the Flinders Range) appear to be forms of $T$. angustifolia marked by trifling variations in the hairs at the base of the stamens.

A perennial aquatic cosmopolitan plant, found growing near water in most parts of the State. Nov.-Dec.

\section{FAMILY 14.-POTAMOGETONACEAE.}

Flowers bisexual or unisexual, solitary or in spikes; perianth of 4 herbaceous segments or often wanting; stamens 1.4 ; carpels $1-8$, each with 1 pendulous ovule ; fruit usually hard, indehiscent, 1-seeded. Water plants, often with very long stems, so as to enable the flowers and floating leaves to emerge.

A. Flowers unisexual, enclosed in a leaf sheath.

B. Flowers monoecious, spicate ............ Zostera 1.

B. Flowers dioecious, solitary.

Anthers and carpels 2 ; leaves linear ......... Cymodocé 2.

Anthers and carpels 3 ; leaves capillary ........ Althenia 3.

A. Flowers bisexual.

C. Flowers in compound spikes.............. Posidonia 4.

C. Flowers in simple pedunculate spikes.

Perianth of 4 segments ................. Potamogeton 5.

Perianth none ..................... RupPia 6.

\section{ZOSTERA, L.}

(Greek zostêr, a girdle : alluding to the ribbon-like leaves.)

Flowers unisexual, male and female in alternate rows forming a flat spike enclosed in the sheathing base of the floral leaf; no perianth; male flowers of 1 subsessile, 1-celled anther; pollen filiform; female flowers of 1 carpel, attached laterally, with a filiform 2 -branched style; ovule 1, pendulous. Submarine plants, with a creeping rhizome and long, grass-like, alternate leaves.

Leaves notched at summit $\ldots \ldots \ldots \ldots \ldots \ldots \ldots \ldots \ldots$

Leaves rounded at summit....................

Z. nana 1 .

Z. tasmanica 2.

1. Z. nana, Roth. Leaves narrow, linear, about $2 \mathrm{~mm}$. broad, bluntly notched at summit, with 1 cental nerve, 2 marginal nerves and 4-6 fine secondary nerves; flowers with bracteoles; fruits smooth.-Z. Muelleri, Irmisch.

Sea-coast. Dec.-Feb.

2. Z. tasmanica, G. V. Martens. Leaves rather broader, rounded at summit or minutely notched; flowers without bracteoles; fruits striate.

Sea-coast.

\section{CYMODOCEA, Koen.}

(Greek Kymodoke, name of a sea-nymph.)

1. C. antarctica (Labill.), Endl. Submarine plant; rhizome creeping and producing upright shoots at the nodes; leaves distichous, broadly linear $(2-7 \mathrm{~cm}$. long, 4-8 $\mathrm{mm}$. broad) truncate or lunate at the summit; flowers solitary, enclosed in the sheathing base of the leaf; male flowers naked; anthers 2, 4-celled, shortly horned at summit, coherent, inserted on a common stalk; pollen filiform ; female flower consisting of twin carpels more or less surrounded by a cup formed of connate membranous bracteoles (perianth ?); style with 3 stigmatic branches ; fruiting carpel a drupe, the horny endocarp becoming a 4-lobed comb-like cup ; embryo germinating within the carpel and producing a young plant which finally breaks away from the branch, along with the "comb," and roots at the bottom of the sea.-Pectinella antar tica, J. M. Black.

Sea-coast. One of the "sea-grasses" and often cast ashore. Sept.-Jan. 
3. ALTHENIA, Fr. Petit.

(After J. Althen, a Persian, who took refuge in France and introduced the cultivation of madder, Rubia tinctorum, in 1760.)

Flowers dioecious, solitary within 1-2 sheathing bracts consisting of the stipules of reduced leaves; male flower on a short pedicel, with 3 sessile, 2 -celled anthers, coherent by their backs so as to appear like a single ovoid, 6-celled anther, and enclosed in one or two inner hyaline bracts; at the base of the anthers are 3 small perianth-segments (or bracteoles?); female flower pedicellate, consisting of 3 distinct, stalked carpels, each ovary tapering into a style with oblique stigma and with a scarious perianth-segment (or bracteole ?) at base ; ovule 1 in each carpel ; pollen globular. Submerged plants, inhabiting fresh or brackish water, with filiform stems and capillary alternate leaves.

The Australian species belong to the section Lepilaena.

Style shorter than the overy .................. australis 1.

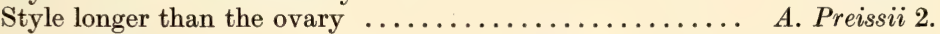

1. A. australis (J. Drumm.), Aschers. Female flower with styles shorter than the ovaries, the perianth segments ovoid, entire, only about $1 \frac{1}{2} \mathrm{~mm}$. long and shorter than the carpel ; fruiting pedicels attaining a length of $2-3 \frac{1}{2} \mathrm{~cm} .-$ Lepilaena australis, J. Drumm.

South-East and at least as far north as Adelaide. Sept.-Nov.

2. A. Preissii (Lehm.), Graebn. Female flower with styles longer than the ovaries, the perianth-segments oblong, bifid at summit, and as long as the young carpel (3 $\mathrm{mm}$.); fruiting pedicels exceeding the sheathing bracts, but not nearly as long as those of the preceding species.-Lepilaena Preissii (Lehm.), F. v. M., and including L. cylindrocarpa (Koern.), Benth.

South-East. Sept.-Nov.

\section{POSIDONIA, Koen.}

(From Greek Poseidōn, Neptune, god of the sea.)

1. P. australis, Hook $\mathrm{f}$. Submarine plant, the base of the stem covered with the fibrous remains of the leaf-sheaths ; leaves long, linear, $3-8 \mathrm{~mm}$. broad, with about 9 fine parallel nerves; flowers bisexual in a compound spike with a long floral leaf at base and shorter floral leaves at the base of each single spike; no perianth; stamens 3 , the connectives lanceolate, persistent and bractlike at the base of the fruit after the 2 basal anther-cells have fallen ; pollen filiform ; carpel 1, sessile, contracted at summit ; stigma 3-4-lobed; ovule 1, erect; fruit about $2 \mathrm{~cm}$. long, obliquely ovoid-acuminate, with fleshy pericarp, dehiscing irregularly at the base.

Sea-coast. May-Sept.

\section{POTAMOGETON, L.}

(Greek potamos, a river ; geitun, neighbor.)

Flowers bi-sexual, in dense simple spikes on axillary peduncles; perianth-segments 4, broad ; stamens 4, inserted at the base of the segments, almost sessile; pollen globular; carpels 4, free, with a rather hard endocarp when in fruit; seed much eurved. Freshwater perennial plants, with alternate leaves, or opposite ones when they are under the branches and peduncles.

A. Leaves all alike, submerged, sessile or nearly so, membranous.

B. Leaves oblong, curly on margins........... P. crispus 1 .

B. Leaves narrow-linear, flat.

C. Leaves not sheathing.

Leaves obtuse, 3-5-nerved ............. P. ochreatus 2

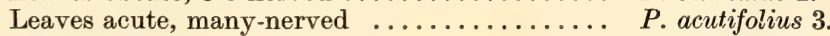

C. Leaves sheathing, very narrow ........... Pectinatus 4 .

A. Leaves dissimilar, the upper ones petiolate, with broad floating blades.

Floating leaves with $18-25$ nerves............. P. Tepperi 5 .

Floating leaves with about 15 nerves............ P. tricarinatus 6 .

1. P. crispus L. Curly Pondweed. Leaves linear-oblong, transparent, obtuse, 5-10 mm. broad, 3-nerved, wavy and crisped on the edges; fruits smooth or crenulate at the back, with a rather acute beak almost as long as the fruit.

Murray, Onkaparinga, and other streams; an obstructive weed in the Torrens Lake (Adelaide). Oct.-Feb. A cosmopolitan plant.

2. P. ochreatus, Raoul. Leaves linear, obtuse, $2-4 \mathrm{~mm}$. broad, with a broad central nerve and usually 2 others near each margin; fruits rather broad, rounded and smooth or crenulate on the back, with a short, usually curved beak. - P. obtusifolius, F. v. M. not of Mertens and Koch.

Southern districts and Kangaroo Island. Nov.-Dec. 
3. P. acutifolius, Link. Resembles the preceding, but the leaves are acute, with numerous fine longitudinal nerves, and the fruits have a small tooth at the base of the inner margin.

Recorded for the River Murray in Victoria, and probably to be found in our State, but I have not seen a specimen.

4. P. pectinatus, I. Stems very slender, dichotomous; leaves narrow-linear, dilated into a long sheathing base, with 2 lanceolate lobes (stipules); fruits rather large (3-4 mm. long), obovoid, with a very short, almost lateral beak.

Creeks and freshwater swamps. Sept.-Dec.

5. P. Tepperi, A. Benn. Upper leaves on long petioles, the lamina floating, ovate or orbicular, sometimes cordate at base, thick, with 19-25 nerves; spike dense cylindrical; fruits obovoid, rounded on back and with 3 almost smooth ribs; beak very short.$P$. natans, R. Br. partly, not of $\mathrm{L}$.

Rivers and swamps of southern and south-eastern districts. Nov.-Jan.

6. P. tricarinatus, A. Benn. Near the preceding, but the leaves are ovate-oblong with 13-17 nerves; fruits with the 3 dorsal ribs strongly crenulate or tuberculate.$P$. natans, R. Br. partly, not of L.

Murray River and in creeks and swamps. Nov.-Jan.

\section{RUPPIA, L.}

(After H. B. Ruppius, a German botanist ; lived 1689-1719.)

1. R. maritima, L. Submerged plant inhabiting brackish water ; leaves long, filiform, clustered, with sheathing bases which shelter the young spike; flowers bisexual, naked, 2, on opposite faces of the axis of the spike ; anthers 2, sessile, 2-celled, pollen globular ; carpels 4-8, with 1 pendulous ovule and peltate stigma; carpels at first sessile, but becoming pedicellate as they ripen and raised to the surface of the water on a long spirally coiled peduncle.

Brackish waters near the sea. Oct.-Dec.

\section{FAMILY 15.-NAJADACEAE.}

Differs from Potamogetonaceae chiefly in the erect ovule, the toothed leaves, and the perianth represented by a membranous cup-shaped bract; flowers unisexual, solitary in the axils of the opposite or whorled leaves; carpel 1.

\section{NAJAS, L.}

(Greek naias, a naiad or water-nymph.)

Flowers dioecious, solitary, axillary ; male flower of 1 anther, with 1 or 4 cells, enclosed in a membranous bract or perianth; pollen globular; female flower of 1 sessile carpel with a 2-3-branched style and 1 small bract. Submerged waterplants; leaves opposite and often appearing whorled.

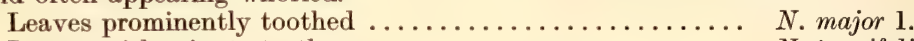

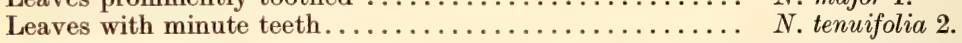

1. N. major, All. Leaves linear, $2-3 \mathrm{~mm}$. broad, sinuately and prominently toothed, the sheathing base not lobed; anther 4-celled; style 2-3-branched.

River Murray. A cosmopolitan species. Jan.-Mar.

2. N. tenuifolia, R. Br. Leaves narrow-linear, $1 \mathrm{~mm}$. broad, with small distant teeth scarcely visible except under the lens, the sheathing base produced into 2 stipular lobes toothed like the leaf-blade; style 2-branched. Mar.

Recorded from the MacDonnell Ranges and probably occurs in our Far North. Jan.-

\section{FAMILY 16.-APONOGETONACEAE.}

Flowers bisexual, arranged in spikes; perianth of 2 petal-like segments; stamens 6-18, in 2 or 3 whorls; carpels $3-6$, each with $2-6$ erect ovules. Freshwater plants.

\section{APONOGETON, Thunb.}

(From Aponus, the Latin name of the town of Albano, and Greek geito n, near.)

* 1. A. distachyus, Thunb. Cape Pondweed. Rootstock bulbous; leaves floating, large, oblong, with long, sheathing petioles; flowers sessile, scented, in terminal forked spikes; the 2 perianth-segments broad, opposite, white; anthers purple.

Creeks near Mount Lofty. Aug.-Nov.--South Africa. 


\section{FAMILY 17.-SCHEUCHZERIACEAE}

Flowers bisexual; perianth-segments herbaceous, 6, in 2 whorls: carpels with 1-2 anatropous ovules. Marsh plants with narrow leaves.

\section{TRIGLOCHIN, L.}

(Greek treis, three; glokhis, a point: alluding to the points of the 3 carpels.)

Flowers in terminal spikes on a simple erect scape ; perianth-segments usually 6 , in 2 whorls ; anthers 6 or 3 , almost sessile ; carpels normally 6 , but 3 often sterile and persistant on the central axis ; ovule solitary, laterally attached. Usually marsh or freshwater plants, with linear radical leaves.

A. Fertile carpels 3, separating from the central axis and alternating with 3 barren persistant carpels.

B. Perennial .......................... striata 1.

B. Small annuals.

C. Carpels truncate, with a spreading point........ T. mucronata 2 .

C. Carpels contracted towards summit.

Carpels with conspicuous basal spurs ........ T. calcitrapa 3 .

Carpels without conspicuous spurs ........... T. centrocarpa 4.

A. Fertile carpels usually 6 , without any barren ones or persistant central axis ................... procera 5 .

1. T. striata, Ruiz et Pav. Stoloniferous perennial with narrow-linear leaves; scape $\mathbf{3 - 3 0} \mathrm{cm}$. high; flowers usually numerous; perfect anthers 3 ; fruits subglobular, the 3 fertile carpels streaked on the back.

Swamps in southern districts. Oct.-Dec.

2. T. mueronata, R. Br. Small annual with very narrow leaves; scape $3-10 \mathrm{~cm}$. high ; flowers few, sometimes only 1 terminating the scape; fruits almost sessile, top-shaped and truncate, the 3 perfect carpels laving each a horizontal mucro at summit.

Swamps in southern districts. Aug.-Sept.

3. T. calcitrapa, Hook. Small annual with filiform leaves ; scape $6-15 \mathrm{~cm}$. high ; fruits pyramidal-linear, 4-6 mm. long, pedicellate or almost sessile, each fertile carpel with 2 long, incurved, basal spurs.

Dry North. Apr.-July.

4. T. centrocarpa, Hook. Dwarf annual with filiform leaves; scape $3-7 \mathrm{~cm}$. high ; fruits pyramidal-linear, $2-5 \mathrm{~mm}$. long, sessile or pedicellate, the carpels with slight protuberances or very short straight spurs at base.

Almost all parts of the State, often in sandy soil. May-Sept.

5. T. procera, R. Br. Robust perennial ; leaves long flat, $1 \mathrm{~cm}$. broad, the upper part floating; scape from 25 to more than $50 \mathrm{~cm}$. high ; flowers numerous ; stamens 6 ; fruits subglobular or oblong.

In or beside rivers, creeks, and lakes, chiefly in the southern districts. Sept.-Nov.

\section{FAMILY 18.-ALISMATACEAE.}

Flowers usually bisexual; sepals and petals 3 ; stamens usually 6 , hypogynous, with erect 2-celled anthers; carpels 6 or more, with 1 to several anatropous ovules. Marsh plants with radical leaves and branched inflorescence.

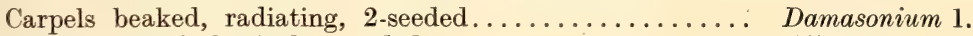

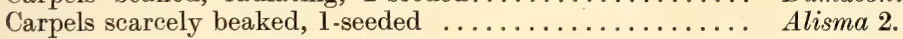

\section{DAMASONIUM, Juss.}

(Greek damazô, to subdue, because one species was said to overcome poison.)

1. D. minor (R. Br.), Buch. Leaves radical, on long petioles, ovate-cordate to lanceolate, with 3-5 primary nerves; stems leafless 20-50 cm. high ; flowers small, paniculate, in 3 or 4 distant whorls and a terminal umbel; petals pale pink, larger than the sepals ; carpels 6-9, compressed, united at base, tapering into a beak, radiating like a star ; seeds oblong, tuberculate.-D. australe, Salisb. (1812); Actinocarpus minor, R. Br. (1810).

Marshes beside the River Murray. Jan.-March.

\section{ALISMA, L.}

(Greek and Latin name of the plant.)

1. A. plantago, L. Water plantain. Rootstock bulbous; leaves on long petioles. ovate-lancenlate, sometimes cordate at base, large, 7-nerved; stem leafless, erect, stiff, $30 \mathrm{~cm}$. to $1 \mathrm{~m}$. high ; flowers small, pale pink, in a large panicle of whorled branches, each branch bearing an umbel; carpels about 20, small, rounded on back and summit, compressed and closely packed in a ring round the depressed axis.

Reedbeds near Adelaide; Onkaparinga River, but probably an escape. Dec.-Feb.A cosmopolitan plant. 


\section{FAMILY 19.-HYDROCHARITACEAE.}

Flowers mostly unisexual, enclosed when young in a spathe; sepals and petals 3 . stamens $3-12$, anthers 2 -ceiled; ovary inferior, adherent to the receptacle, more or less i-celled, with numerous ovules attached to parietal placentas: style with 3-8 stigmas fruit indehiscent, ripening under water. Submerger water-plants.

A. Freshwater plants.

B. Flowers large, bisexual

OtTelia 1.

B. Flowers small, dioecions.

C. Leaves long and radical.

Spathe tutular; petals present ................... BLYXA 2.

Spathe ovoid; petals absent in the male flowers.. VALLISNERIa 3.

C. Leaves short, whorled ........................ HydrmLA 4.

A. Saltwater plant; leaves broad, in pairs .......... HalophILA 5.

\section{OTTELIA, Pers.}

(From ottel-ambel, the native name of an Indian species.)

1. O. ovalifolia (R. Br.), L. C. Rich. Leaves radical, on long petioles, mostly with ovate or oblong blades floating on the water; flowers bisexual, solitary and sessile within a 2-lobed tubular 6-ribbed spathe at the summit of the peduncle ; calyx-lobes green, 2-3 cm. long; petals longer; stamens 6-12; stigmas 6-8, 2-lobed; ovules numerous, anatropous, on 6-8 protruding placentas.

Reedbeds; Rivers Murray, Onkaparinga, Glenelg, and other fresh waters. Jan.-March.

\section{BLYXA, Noronha.}

1. B. octandra, (Roxb.), Planch. Leaves long and grasslike, submerged; flowers dioecious, on slender peduncles, the males several, protruding from a 2-toothed tubular spathe ; stamens about 8 ; sepals 3 , about $5 \mathrm{~mm}$. long; petals 3 , twice as long; female flowers solitary within a longer spathe; stigmas 3 ; ovules numerous on 3 placentas, anatropous.-B. Roxburghii, Rich.

Recorded by Bentham from "waters near Lake Torrens, F. Mueller," but does not appear to have been found since then. It occurs in Northern Australia and tropical Asia

\section{VALLISNERIA, Mich.}

(After Antonio Vallisnieri, an Italian doctor and botanist, 1661-1730.)

1. V. spiralis, L. Rootstock stoloniferous; leaves all submerged and radical, long, linear, usually minutely toothed towards the summit; flowers dioecious, the males minute, numerous in an ovoid 3-lobed pedunculate spathe, the male flowers pedicellate, with 2-3 stamens and 3 sepals, the females solitary in a tubular bifid spathe, on a long filiform spirally coiled peduncle, which unfolds so as to enable the flower to reach the surface ; calyx-lobes 3 ; petals 3 , rudimentary ; ovary 1-celled, with 3 parjetal placentas ; ovules orthotropous.

Chiefly in rivers and streams. Jan.-Mar. A tropical and subtropical plant in all parts of the world.

\section{HYDRILLA, Rich.}

(A diminutive of Hydra, the water serpent slain by Hercules.)

1. H. verticillata (L.), Casp. Leaves lanceolate, serrulate, about $1 \mathrm{~cm}$. long, in whorls of 4-8 along the submerged stems and branches; flowers dioecious, solitary in short tubular spathes; male spathes on short peduncles; stamens 3 ; female spathes sessile and solitary, shorter than the leaves; sepals and petals 3 ; ovary cylindrical, 1-celled with 3 parietal placentas; ovules orthotropous; style long with 3 filiform stigmas.

River Murray.

\section{HALOPHILA, Thou.}

(Greek hals, halos, the sea ; philos, lover.)

1. H. ovalis (R. Br.), Hook f. Submarine plant; leaves in pairs at each node, oblonglanceolate, $2.7 \mathrm{~cm}$. long, with a central nerve, 2 fine marginal nerves and about 20 oblique secondary nerves, the 2 petioles long and slender and furnished at base with 2 broad scarious scales; flowers unisexual, solitary within a 2-leaved sessile axillary spathe; male flowers pedicellate and emerging from the spathe, the females sessile within it; sepals 3 ; anthers 3 , sessile ; pollen filiform ; ovary 1-celled, tapering into a long beak, at the summit of which are the 3 minute sepals of the female flower and 3 long filiform. stigmas ; fruit ovoid, membranous about $10 \mathrm{~mm}$. long; seeds numerous, with a loose hyaline testa and smooth white endopleura; embryo with a large hypocotyl and the cotyledon coiled horizontally above it.

Sea-coasts. Nov.-Jan. 


\section{FAMILY 20.-GRAMINEAE.}

Flowers small, bisexual, rarely unisexual, naked, in the axil of a concave bract called the flowering glume, opposite to and enclosed in which is another usually 2-nerved bract
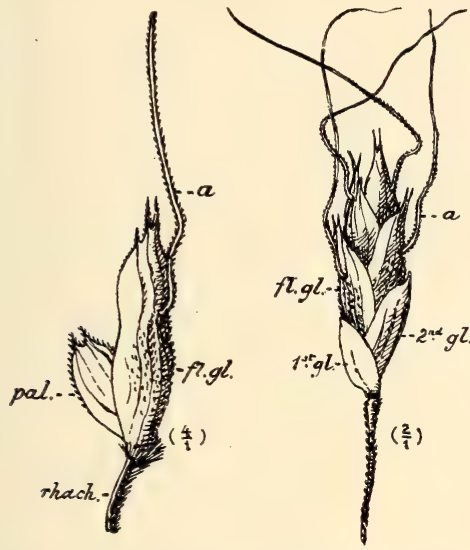
called the palea. The paiea envelops the flower, which consists of a 1-celled carpel with one ovule and 2 styles with feathery stigmas, and usually 3 stamens with versatile anthers The term "flower" is, however, generally under stood to include the flowering glume and palea At the base of the ovary are 2 (rarely 3 ) minute delicate bracteoles or scales named lodicules. Below the flowering glume and palea, and enclosing them more or less, are 2 (rarely 3 or 4) empty bracts called the outer or empty glumes. All these together form a 1-flcwered spikelet, but there may be several flowers arranged alternately on opposite sides of a common axis (the rhachilla) - so that the upper flowers often appear to be stalked-with the outer glumes at the base, the whole forming a severalflowered spikelet; spikelets arranged in a spike, raceme or panicle. The fruit (grain or caryopsis) consists of the single albuminous seed and the thin pericarp, which are usually inseparable. FIG. 18 - Spikelet of Amphibromus nervosus. At the base of the grain, and on its anterior empty glume; $f$. gl., flowering glume; $a$, side (i.e., that which faces the flowering glume), awn; pal. palea; rhach. article of rhachilla is a small protuberance showing the position of supportıng the flowering glume. the embryo; on the posterior side (that facing the palea) is either a punctiform or linear mark

(the hilum), which indicates the spot where the ovule was attached to the wall of the ovary ; the hilum often lies in a furrow.

Herbs ("grasses") with alternate linear leaves, embracing the stem with long sheaths, which are slit at maturity on the side opposite to the blade; sheath ending at the base of the blade in a tongue-like membrane (ligule), sometimes very short or reduced to hairs ; stems usually hollow between the nodes.

1. Pedicel articulate below the outer glumes, so that the ripe spikelet falls off as a whole; spikelets with 1 fertile flower.

A. Outer glumes 2 ; inflorescence a spike or spikelike panicle.

B. Spikelets not awned.

Flowering glume hard

Paspalum 10.

Flowering glume thin, 2nd glume bristly......... Tragus 7 .

B. Spikelets awned.

C. Outer glumes awnless.

Flowering glume with a terminal awn $\ldots \ldots \ldots \ldots$ ERIOchLOA 11.

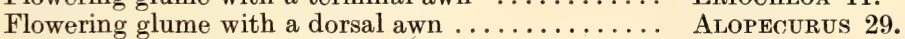

C. Outer glumes with long awns.

Flowering glumı awnless ................. Perotis 9.

Flowering glume shortly awned .............. Polypocon 31.

A. Outer glumes 3 , the 3 rd sometimes containing a male flower.

D. Spikelets not awned.

E. Flowering glume hardened, usually longer than the outer ones.

F. Spikelets bisexual.

G. Spikelets with a bristly involucre ; panicle usually spikelike.

H. Bristles persistant.

Bristles several below each spikelet ........

Bristle 1 below terminal spikelet...........

H. Bristles deciduous with spikelets.

Bristles slender. surrounding spikelet .......

Bristles unilateral, terminating flattened

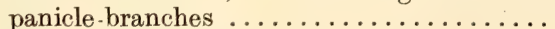

Bristles stiff, connate in lower part........

G. Spikelets without bristly involucre; panicle

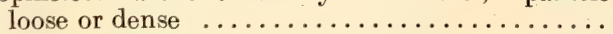

F. Spikelets unisexual, in clustered spikes..........

E. Flowering glume thin, usually small; 3rd empty glume thin and inconspicuous.

Setaria 14.

Chamaeraphis 18 .

Pennisetum 16.

Plagiosetum 17.

Cenchrus 15.

Panicum 13.

SPINIFEX 19. 
I. Spikelets in a dense spike, 1 or both outer glumes

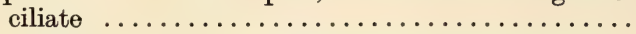

I. Spikelets in pairs, one sessile, the other pedicellate.

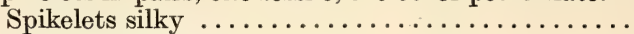

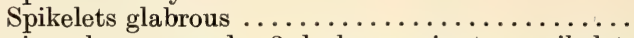

D. Flowering glume awned; 3rd glume minute; spikelets arranged in spikes.

J. Spikelets in pairs or triplets, 1 sessile and 1 or 2 pedicellate.

Both spikelets fertile $\ldots \ldots \ldots \ldots \ldots \ldots \ldots \ldots \ldots$

Sessile spikelet only fertile ; flowering glume awnlike..

J. Spikelets in triplets, surrounded by 4 sterile spikelets. Triplet disarticulating below callus, leaving the 4

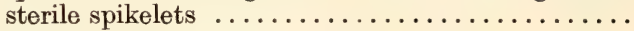

Triplet falling off with the 4 sterile spikelets........

Neurachne 8.

IMPERATA 1.

RotTBoEllia 3.

\section{Pollinia 2.}

Andropogon 4.

\section{Themeda 5.}

ISEILEMA 6.

2. Pedicals not articulate below the 2 outer glumes, but the axis (rhachilla) of the spikelet usually articulate above the outer glumes and below the flowering glumes, so that, when the latter have fallen, the outer glumes still remain at the summit of the pedicel.

K. Spikelets with 1 fertile flower.

L. Flowering glumes entire or slightly bilobed, awnless or with a single unbranched awn.

M. Spikelets in solitary terminal spikes.

Spikelets solitary in alternate notches ........ LEPTURUs 74 .

Spikelets 3 together .................... Hordeum 76.

M. Spikelets in digitate spikes.

Flowering glume awned $\ldots \ldots \ldots \ldots \ldots \ldots \ldots \ldots$

Flowering glume awnless ...............

ChLoris 69.

Cynodon 68.

M. Spikelets arranged in a panicle.

N. Outer glumes 2.

O. Flowering glume awnless ; perennials.

P. Outer glumes longer than flowers.

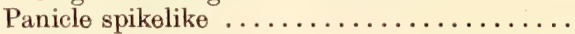

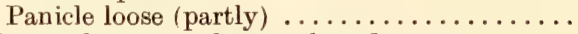

P. Outer glumes not longer than flowers.........

O. Flowering glume usually with a twisted awn; panicle loose or dense ; perennials..........

Q. Awn dorsal near middle or base of glume.

Callus with a tuft of hairs ............

Callus glabrous or almost so (partly)......

Q. Awn dorsal, near summit of glume .........

Q. Awn terminal, long; panicle loose.........

o. Flowering glume with a short straight awn.

Awn terminal ; panicle loose ; perennial......

Awn dorsal; panicle spikelike; annual......

O. Flowering and outer glumes awned; panicle dense,

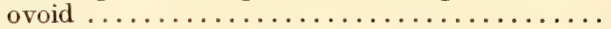

N. Outer glumes 4.

R. Two lowest glumes shorter than flower.

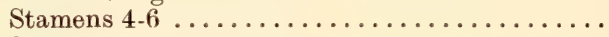

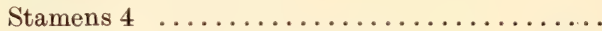

R. Two lowest glumes longer than flower; panicle dense.

3rd and 4th glumes awned $\ldots \ldots \ldots \ldots \ldots \ldots \ldots$

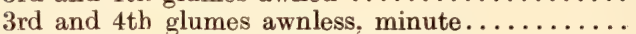

L. Flowering glume with a 3 -branched awn $\ldots \ldots \ldots \ldots \ldots$

L. Flowering glume 3-9-lobed; panicle usually dense.

S. Flowering glume 3 -lobed.

All 3 lobes ending in awns.................

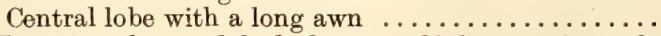

S. Flowering glume 5-lobed, the central lobe conspicuously

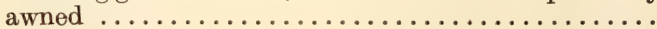

K. Spikelets with 1 fertile flower and 1 male or empty flower above it.

T. Lower flower bisexual; flowering glume rather thin; panicle narrow.

Flowering glume with 1 slender awn or awnless.

Upper flower male; spikelets all alike..........

Upper flower empty; many spikelets barren .....

Flowering glume with 9 stiff plumose awns .........

Ammophila 36.

Agrostis 32.

Sporobolus 30 .

Calamagrostis 33.

Agrostis 32.

Dichelachne 35.

STIPA 26.

OrYzopsis 27.

GastridiUM 34.

LAGURUS 38.

Ehrharta 20.

Microlaena 21.

Anthoxanthum 23.

Phalaris 22.

Aristida 25.

Amphipogon 24.

EOHINOPOGON 28.

Pentapogon 37.

Holcus 43.

LAMARCKIA 53.

PAPPOPHORUM 47. 
T. Lower flower usually female ; flowering glume hardened

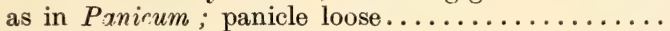

K. Spikelets with 2 fertile flowers.

U. Flowering glume with a short dorsal awn ; outor glumes 1-3-nerved; panicle loose.

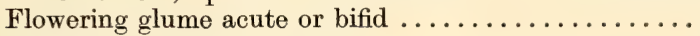

Flowering glume truncate $\ldots \ldots \ldots \ldots \ldots \ldots \ldots$

U. Flowering glume awnless or with a short terminal awn; outer glumes 9 -11-nerved ................

U. Flowering glume with a long terminal awn and 2 lateral

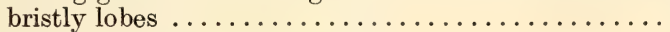

K. Spikelets with several fertile flowers.

V. Flowers enveloped in long hairs ; panicle large.......

V. Flowers not enveloped in long hairs.

W. Flowering glumes entire, awnless or shortly awned.

$\mathrm{X}$. Spikelets sessile in a terminal spike.

Y. Spike compressed; spibelets solitary in notches of rhachis.

Outer glume $1 \ldots \ldots \ldots \ldots \ldots \ldots \ldots \ldots$

Outer glumes $2 \ldots \ldots \ldots \ldots \ldots \ldots \ldots \ldots$

Y. Spike cylindrical; spikelets in globular clusters

$X$. Spikelets shortly pedicellate in a terminal spike....

X. Spikelets sessile in several digitate or scattered spikes.

Spikelets crowded; spihes digitate ..........

Spikelets more distant; spikes scattered .......

X. Spikelets in a loose or contracted panicle.

Z. Flowering glume rounded on back.

AA. Spikelets drooping and quivering ........

AA. Spikelets erect; flowering glume 5-nerved.

Flowering glume acute, awnless, or with a short terminal awn, the lateral nerves converging towards summit ..........

Flowering glume obtuse, awnless, the lateral nerves almost parallel ..............

Z. Flowering glume keeled on back.

BB. Spikelets bisexual.

CC. Spikelets in compact clusters; flowering glume shortly awned ............

CC. Spikelets not clustered.

DD. Ligule membranous.

Flowering glume thin and usually woolly at base ..............

Flowering glume hard and glabrous at

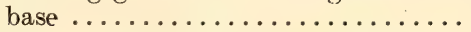

DD. Ligule of hairs; flowering glume 3 -

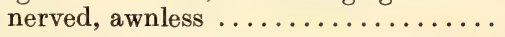

BB. Spikelets unisexual and dioecious, awnless.. W. Flowering glume 3 -lobed or notched, the midnerve produced into an awn within the notsh.

EE. Spikelets of 2 kinds, the fertile surromded by

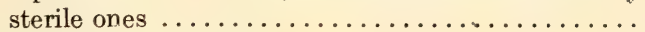

EE. Spikelets of 1 kind.

FF. Spikelets forming a narrow panicle.

GG. Outer glumes shorter than the flowers.

HH. Flowering glume 3-nerved.

Flowering glume with a straight awn half its length ...............

Flowering glume with 3 subequal teeth Flowering glume with 3 lobes tapering into long straight awns ..........

HH. Flowering glume 5-nerved, bifid, with a slender straight awn ............

GG. Outer glumes as long as flowers ; flowering glume 9-nerved.

Flowering glume 2-lobed, with a twisted awn Flowering glume bifid and mucronate ......

ISACHNE 12.

AIRA 40.

Deschampsia 41 .

Eriachne 39.

Pentasciistis 46.

Phragmites 52.

LoLIUM 73.

Agropyrum 75.

Elytrophorus 49 .

BRACHYPODICM 67.

Dactyloctenium $7 \mathrm{l}$.

LEPTOchloa 72.

BRIZA 57.

Festuda 65.

GLyceria 63.

Dactyyls 58.

PoA 62.

SclerochloA 64.

Eragrostis 59.

Distichlis 60 .

Cynosurus 54.

KoEleria 55.

Triodia 50.

TRIRAPHIS 48.

Trisetum 56.

Danthonia 45.

Schismus 61. 
FF. Spikelets in a cylindrical spike ; flowering glume

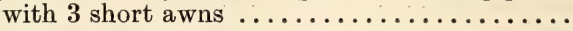

FF. Spikelets sessile in a unilateral spike; lateral lobes long, rigid, with awn between them ...

FF. Spikelets in a simple spike or panicle; lateral lobes membranous, with a short awn ......

W. Flowering glume bifid, with a long dorsal awn; spikelets panicled; grain hairy.

Outer glumes enclosing the 2-3 flowers; awn bent

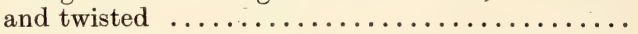

Outer glumes shorter than the 5-14 flowers; awn usually straight .....................

W. Flowering glume denticulate; awn dorsal and bent; grain glabrous.......................

Elytrophorus 49.

Astrebla 70.

Diplachne 51.

Avena 42.

Bromus 66.

Amphibromus 44.

1. Spikelets with 1 fertile flower, without any continuation of the rhachilla beyond the flower, and falling off as a whole from the jointed pedicel when ripe.

Tribe 1.-Andropogoneae. Flowering glume and palea membranous, the flowering glume usually awned; outer glumes stiff, enclosing the others; spikelets compressed dorsally, usually in articulated racemes or spikes, either bisexual, or the male and bisexual spikelets mixed in the inflorescence, so that a male spikelet stands beside a tertile one; hilum punctiform.

\section{IMPERATA, Cyr.}

(After Ferrante Imperato, a Neapolitan botanist, 1550-1625.)

1. I. cylindrica, (L.), Beauv. A handsome perennial grass, $30-100 \mathrm{~cm}$. high ; leaves flat, erect; panicle spikelike silky-white $5-20 \mathrm{~cm}$. long; spikelets 1-flowered, usually in pairs and one on a shorter pedicel ; empty glumes 3 , hyaline, the 2 outer villous on back, the 3rd smaller, and the flowering glume and palea smaller still; stamens 1 or $2 .-I$. arundinacea, Cyr.

Adelaide Plains; Mount Lofty Range; Port Lincoln; Naracoorte; but apparently rare. Aug.-Mar.

\section{POLLINIA, Trin.}

(After Ciro Pollini, an Italian botanist, 1782-1833.)

1. P. fulva, (R. Br.), Benth. Sugar-grass. A rather tall perennial, growing in tussocks ; leaves flat; ligule ciliate or glabrous ; spikes $2-4$ sessile in a terminal cluster, $4-8 \mathrm{~cm}$. long, colored a reddish-brown by the silky hairs of the 2 lowest glumes; spikelets in pairs, both fertile; empty glumes normally 3, the 2 outer truncate, $5 \mathrm{~mm}$. long, the 3rd one minute and often wanting; flowering glume hyaline and inconspicuous except for the bent and twisted awn.-Erianthus fulvus, Kunth.

Near River Murray and in Far North. Flowering most of the year.

\section{ROTTBOELLIA, L. f.}

(After C. F. Rottböll, professor of botany at Copenhagen, 1727-97.)

1. R. compressa, L. f. Mat Grass. Rather rigid ascending perennial ; leaves narrow, the lowest ones sometimes hairy; spikes solitary, terminal, compressed, rigid $6-13 \mathrm{~cm}$. long; spikelets in pairs, appressed in the notches of the spike, one sessile, the other apparently opposite to it, because its pedicel is adnate to and appears to form part of the rhachis of the spike; both spikelets usually bisexual; empty glumes of the sessile spikelet 3, the outermost green, faintly many-nerved, rigid, acuminate, the 2nd adnate to and obliterated in the rhachis, the next one thin; flowering glume also thin and the palea small ; pedicellate spikelet the same, except that the 1st and 2nd glumes are distinct, rigid, green, and are rather longer (10 mm.), with subulate points; anthers purple.Hemarthria compressa, R. Br.

In or close to rivers and streams. Jan.-March. Resembles Lepturus cylindricus, but the latter has the spikelets solitary and alternate, and the nerves of the first or outermost glume are very prominent.

\section{ANDROPOGON, L.}

(Greek anèr, andros, a man ; pōgìn, beard ; alluding to the silky spikes.)

Spikelets 1-flowered, compressed dorsally, arranged in pairs or triplets in a racemose spike or loose panicle, 1 sessile and f rtile (bisexual), the other, or 2 others, pedicellate and barren (male or empty); empty glumes of the fertile spikelet 3 , the 1st rather larger 
than the 2nd, which is keeled, the 3rd small and hyaline ; flowering glume also small and thin, with a long terminal bent and twisted awn; palea minute or none ; barren spikelets awnless. Erect perennial grasses, with leafy stems.

A. Spikelets in pairs, or the terminal ones in 3 's, and arranged in spikes.

B. Spikes 2 or more, clustered at or near the summit of the stem.

C. Articles of the spike with a translucent channel or furrow between the thickened ciliate-villous margins ; spikes numerous ...............

C. Articles of the spike opaque ; lowest sessile spikelets barren.

Lowest glume hairy on back as well as at summit

Lowest glume glabrous on back ..............

B. Spikes 2 together, densely silky-hairy within or just above a leafy sheathing bract.

D. Spikes usually erect, awn prominent ............

D. Spikes finally reflexed; awn very short ..........

A. Spikelets mostly in 3's (1 sessile and fertile between 2 pedicellate barren ones), arranged in a loose panicle.

E. Spikes reduced to 1 triplet of spikelets ............

E. Spikes composed of several triplets or pairs .........

\section{A. intermedius 1.}

A. sericeus 2 .

A. annulatus 3 .

A. exaltatus 4.

A. bombycinus 5 .

1. A. intermedius, R. Br. Blue Grass. An erect grass; nodes bearded; ligule ciliolate, usually with long hairs behind it; spikes $3-7 \mathrm{~cm}$. long, 3 to over 20 in number, pedunculate on an elongated axis and sometimes forming a panicle 10 or $12 \mathrm{~cm}$. long; spikelets light-colored or purplish; lowest glume obtuse, 7-9 nerved, ciliate on margins and villous at base, otherwise glabrous, sometimes pitted on back; awn 15-20 mm. long.

Far North. Dec.-June.

2. A. sericeus, R. Br. Erect grass; nodes bearded; ligule glabrous, but with long hairs rising from the blade behind it; spikes 2-7, sessile at the summit of the stem, $4 \cdot 6$ $\mathrm{cm}$. long, densely clothed with silky hairs; the lowest sessile spikelets barren; lowest glume with 7 to 9 nerves not reaching to its summit, hairy on the lower part of the back and also with long hairs seated on tubercles at the summit; awn about $2 \mathrm{~cm}$. long.

Sturt River (perhaps introduced in this locality); North and Far North. Dec.-Apl.

3. A. annulatus, Forsk. Very near the preceding, but the clothing of the spikes is not so dense, and the lowest glume is glabrous on the back, except for the tuft of hairs on the callus and the long tubercle-seated hairs at the summit. Usually found here in the var. humilis, Benth., which has 3-5 spikes, shorter than in the type $\left(1 \frac{1}{2}-2 \frac{1}{2} \mathrm{~cm}\right.$. long) and most of the leaves with scattered, tubercle-seated hairs.

Near Oodnadatta and Lake Frome. Dec.-Apl.

4. A. exaltatus, R. Br. Scent-grass. A handsome scented grass, $30 \mathrm{~cm}$. to $2 \mathrm{~m}$. high ; leaves with long narrow points; ligule long, glabrous; nodes glabrous; spikes twin or rarely 3 together, emerging from a sheathing bract about as long as they, 2-21 $\mathrm{cm}$. long, densely silky-villous owing to the long hairs arising from the pedicels and articles of the rhachis, erect or the lower ones sometimes spreading, forming together a narrow panicle; lowest glume glabrous, with 2 winged marginal nerves; flowering glume 2-lobed; awn about $1 \frac{1}{2} \mathrm{~cm}$. long.

Flinders Range from Crystal Brook northwards; Far North. Nov.-June.

5. A. bombycinus, R. Br. Silky Heads. Near the preceding, but the leaves have not the long points and the panicle is shortly branched; sheathing bracts about as long as the 2 spikes, which are finally bent downwards; awn inconspicuous (about $1 \mathrm{~cm}$. long), very slender.

Near Gawler; Murray lands; Far North. Dec.-June.

6. A. Gryllus, L. Rather tall almost glabrous grass ; ligule very short, ciliate ; panicle loose, of simple whorled capillary branches, each terminating in a spike reduced to 3 spikelets, 1 sessile and fertile and 2 male and pedicellate; a tuft of reddish hairs at base of each spike; fertile spikelet 6-10 $\mathrm{mm}$. long, lowest glume rigid, acute, 5-7 nerved, the 2 lateral nerves almost muricate; 2nd glume awned; flowering glume notched, with a long bent awn; lowest glume of pedicellate spikelets awned.-Chrysopogon Gryllus, Trin.

Far North. Nov.-June.

* 7. A. halepensis, (L.), Sibth. Johnson Grass. Tall glabrous grass, with stout stems downy or glabrous at the nodes; leaves flat; panicle loose, pyramidal; terminal spikelets in 3 's, the lower ones usually twin ; 2 outer glumes of fertile spikelet stiff, equal, pubescent, 
finally smooth and shining; flowering glume with or without a short, bent awn rising from the notch. - Sorghum halepense, Pers.

A cultivated Mediterranean fodder grass, spontaneous near creeks descending from the Mount Lofty Range and other places. Jan.-May.

\section{THEMEDA, Forsk. (1775).}

(Forskâl says themed is the Arabic name of Th. triandra, but there appears to be some confusion, as themed (thamad) means a depression where water lies after rain and dries up in summer, and is therefore the equivalent of the Australian " claypan " or "waterhole.")-Anthistiria, L. f. (1779).

Spikelets 1-flowered or empty, clustered on the fragile rhachis of short racemose spikes, each spike subtended by a sheathing bract; 4 male or barren sessile persistant spikelets whorled at the base of, and forming a sort of involucre round 1 fertile spikelet, sessile between 2 pedicellate male or empty ones, which occupy the summit of the spike ; glumes of the fertile spikelet almost as in Andropogon; male or barren spikelets awnless.

Fertile spikelets white and glabrous except at summit .... Th. triandra 1.

Fertile spikelet densely pubescent with brown hairs ..... Th. avenacea 2 .

1. Th. triandra, Forsk. Kangaroo Grass. Tall almost glabrous perennial ; leaves narrow; ligule very short, ciliolate; each spike shortly pedunculate within the leafy sheathing bract, which exceeds it in length, and all together forming a short leafy panicle ; all the male or barren spikelets greenish, acute ; outer glume of fertile (bisexual spikelet) firm, white, shining, with a few golden hairs at summit and a tuft of golden hairs on the acute callus; flowering glume consisting of little but the bent, pubescent awn, 5-7 $\mathrm{cm}$. long.-Th. Forskalii, Hack. ; Anthistiria imberbis, Retz. ; A. ciliata. Benth. not of L. f.

All over the State; an excellent fodder grass. Aug.-Nov.-Occurs also in Arabia, India, and Africa.

2. Th. avenacea (F. v. M.), Maid. et Betche. Tall Oat Grass. Differs from the preceding in having a woolly base; the spikes (within the sheathing bracts) having a rather longer and more slender peduncle, and in the 2 outer glumes of the fertile spikelet, which are pubescent with appressed brown hairs.-Anthistiria avenacea, F. v. M.

Far North.

\section{ISEILEMA, Anderss.}

(Greek isos, equal ; eilem $x$ a covering or involucre ; alluding to the 4 involucral spikelets.)

Differs from Themeda in each spike being articulated at its base, so that it falls away as a whole after flowering, whereas in Themeda the articulation occurs above the 4 barren involucral spikelets, which remain attached to the peduncle, while the upper 3 ( 1 fertile and 2 pedicellate and barren) fall off at maturity.

I. I. membranacea (Lindl.), Anderss. Almost glabrous often small annual grass; leaves flat with striate sheaths; spikes forming a short, fragile panicle ; floral bracts resembling the leaves and scabrous on margins and keel; the 4 involucral spikelets shortly pedicellate, obtuse ; flowering glume reduced to a fine awn, 1-2 cm. long.-Anthistiria membranacea, Lindl.

Far North. Dec.-Aug.

Tribe 2. Zoysieae. Flowering glume and palea membranous, the former without an awn: the second empty glume usually larger than the others; spikelets solitary or in non-articulated (continuous) spikes, dorsally compressed; hilum punctiform.

\section{TRAGUS, Haller.}

(Greek tragos a he-goat; alluding to the rigid hairs bordering the leaves and to the bristles on the spikelets.)

1. T. racemosus (L.), Haller. Small Bur Grass. Annual, with spreading stems geniculate at the nodes: leaves flat, bordered by rigid cilia ; ligule of short hairs ; panicle spikelike, 5-10 cm. long; spikelets 1-flowered, 2-3 sessile on very short peduncles which fall off with them; empty glumes 3, the lowest minute or obsolete; the 2nd large, hard, and furnished with 5 rows of hooked bristles on the back; flowering glume and palea membranous and smaller.-Lappago racemosa, Honck.

Murray and northern districts. Nov.-April-_Common in tropical and subtropical countries.

\section{NEURACHNE, R. Br.}

Greek neuron, nerve ; akhne, husk, glume : alluding to the many-nerved outer glumes.)

Spikelets with 1 bisexual flower and rarely a male one below it, each spikelet with a tuft of hairs at base and arranged in a spike; outer glumes 3 , the 2 first subequal, the 2nd villous-ciliate, the 3rd smaller and with a palea, flowering glume also small and thin, 
3-nerved, with a palea about as long as itself. Rigid perennial almost glabrous grasses

with leafy stems, ligule of hairs, and bulb-like rootstocks massed together.

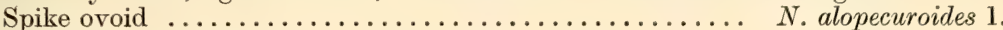

Spike narrow-cylindrical.

First glume with a window-like cavity ; hairy....... N. Mitchelliana 2.

First glume opaque, almost glabrous ............ N. Munroi 3.

1. N. alopecuroides, R. Br. Leaves mostly basal, short, rigid ; spike ovoid or oblong, $2-2 \frac{1}{2} \mathrm{~cm}$. long, dark; spikelets $6-8 \mathrm{~mm}$. long; 2 outer glumes acuminate, 7-9-nerved silky-villous, 3rd glume 7 -nerved.

Most parts of the State. Sept.-Dec.

2. N. Mitchelliana, Nees. Mulga grass. Rootstock woolly; spikes narrow-cylindrical, $2-4 \mathrm{~cm}$. long, light-colored; spikelets about $4 \mathrm{~mm}$. long; 1 st glume 5 -nerved, bearded at base, with a membranous transparent cavity in its lower half and a tuft of long hairs above the cavity; 2nd glume villous-ciliate in the lower half, obtuse or minutely 3 . toothed at summit.

Far North and Murray River district. Oct.-April.

3. N. Munroi, F. v. M. Resembles the preceding, but the spikelets are $5-6 \mathrm{~mm}$. long, the lst glume glabrous or almost so and without a transparent cavity ; 2nd glume acutely acuminate, prominently nerved, villous-ciliate in lower half.

Far North and North-West; Murray district. Oct.-April.

\section{PEROTIS, Ait.}

(Greek Feros, deficient; alluding probably to the minute palea.)

1. P. rara, R. Br. Slender perennial almost glabrous grass; leaves lanceolate ; ligule very short, ciliolate; spikelets 1 -flowered, subulate, finally reflexed, $2-3 \mathrm{~cm}$. long (with the awns), forming a spike $8-20 \mathrm{~cm}$. long; outer glumes 2, linear, rigid, long-awned ; flowering glume smaller, hyaline; palea minute.

\section{Far North.}

Tribe 3. Paniceae. Flowering glume and palea firmer in texture than the outer glumes, the lowest glume usually smaller than the 2nd; spikelets falling off singly from the branches of a panicle or from the non-articulated rhachis of the spike; hilum punctiform.

\section{PASPALUM, L.}

(Greek paspalos, millet.)

1. P. distichum, L. Perennial grass, with creeping rootstock and ascending stems, glabrous except at the orifice of the leaf-sheaths; ligule short, obtuse; spikelets 1flowered, $3.4 \mathrm{~mm}$. long, dorsally compressed, sessile in 2 rows along one side of the flattened rhachis of twin terminal spikes $2-5 \mathrm{~cm}$. long; outer glumes 2, membranous, equal, 3 . nerved; flowering glume and palea hardened as in Panicum.

Rooting in moist sand, Waterfall Gully ; River Torrens ; Murray Bridge. Native of eastern Australia and many warm countries; not recorded here until 1908, and perhaps introduced. Dec.-Mar.

\section{ERIOCHLOA, H. B. et K.}

(Greek erion, wool ; khloè, grass.)

1. E. punctata (L.), Hamilt. Erect perennial with leafy stems, glabrous except the inflorescence; ligule of short white hairs; spikelets 1-flowered, pedicellate, 3-4 mm. long, with a hardened cuplike base, which is articulate on the short pedicel; spikelets arranged in 2 rows along the rhachis of racemes which form the branches of a simple panicle; outer glumes 2, equal, 5-nerved, acuminate, silky-hairy ; flowering glume shorter, with a short terminal point or awn, coriaceous as in Panicum.-E. annulata (Fluegge), Kunth ; E. polystachya, H. B. et K.

Var. acrotricha, Benth. Outer glumes silky-villous, tapering into long points or awns, 1st glume $10 \mathrm{~mm}$. long, 2nd glume $7-8 \mathrm{~mm}$.

Far North. Oct.-Aug.

\section{ISACHNE, $\mathrm{R} . \mathrm{Br}$}

(Greek isos, equal; akhnè, glume : all the glumes are nearly equal.)

1. I. australis, R. Br. Slender perennial grass, with creeping rootstock; leaves flat, rather rough ; ligule of hairs ; spikelets ovoid, slightly compressed dorsally, small (about $2 \mathrm{~mm}$. long), enclosing 1 female flower and 1 male flower below it, or 2 bisexual flowers, on capillary pedicels not articulate below the outer glumes, but the rhachilla of the spikelet articulate above them; spikelets forming a loose panicle with many filiform branches; outer glumes 2, ovate, convex, 5-7-nerved, nearly equal; flowering glume and palea almost as long, hardened and shaped as in Panicum.

Swampy land at Myponga (Mount Lofty Range). 


\section{PANICUM, L.}

(Latin name of Millet ( $P$. miliaceum), the grain of which was mixed with bread (panis) in early times.)

Spikelets with 1 fertile bisexual flower and occasionally a male one below it, usually paniculate; outer glumes 3 , the lst smaller than the others, the 3rd sometimes enclosing a palea or male flower; flowering glume and palea usually almost equal, hard, smooth or wrinkled, usually whitish, sometimes dark-colored.

A. Spikelets glabrous or almost so.

B. Lowest glume not half as long as spikelet.

C. Panicle-branches alternate, simple or almost so $\ldots . . P$. adspersum 1 .

C. Panicle-branches simple, spike-like.

D. Spikes clustered at top of stem $\ldots \ldots \ldots \ldots \ldots \ldots$ P. sanguinale 2 .

D. Spikes alternate along stem.

Spikes finally deflexed $\ldots \ldots \ldots \ldots \ldots \ldots \ldots$. distachyum 3

Spikes erect .................... P. helopus 14 .

C. Panicle-branches divided, long and slender; lowest glume truncate ....................... Pecompositum 4.

B. Lowest glume at least half as long as the spikelet.

E. Panicle large, its branches divided.

F. Leaves glabrous; lowest glume obtuse ....... P. prolutum 5.

F. Leaves more or less hairy ................ effusum 6 .

E. Panicle-branches simple, spike-like.

G. Panicle rather long.

Spikes deflexed ................. P. reversum 7 .

Spikes erect................... Pracile 8.

G. Panicle very short $\ldots \ldots \ldots \ldots \ldots \ldots \ldots \ldots \ldots$ P. pauciflorum 9.

A. Spikelets hairy.

H. Panicle-branches long, divided; spikelets silky.

Spikelets ovoid, $2 \frac{1}{2} \mathrm{~mm}$. long $\ldots \ldots \ldots \ldots \ldots \ldots \ldots$. divaricatissimum 10.

Spikelets oblong, $4 \mathrm{~mm}$. long .............. coenicolum 11.

H. Panicle-branches short, spike-like.

I. Spikes erect; spikelets silky ...............

I. Spikes somewhat spreading; spikelets more or less hairy.

J. Spikes slender, not bristly.

3rd glume without long hairs; spikelets often

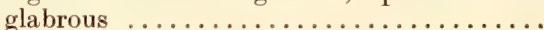

3rd glume ciliate with long hairs..........

J. Spikes broad, bristly ...................

P. leucophaeum 12.

\section{P. helopus 13. \\ P. Gilesii 14. \\ P. crus-galli 15}

1. P. adspersum, Trin. Glabrous except the ciliate nodes; leaves flat, broad at base, ligule short, ciliate; panicle narrow, its branches scarcely divided: lower spikelets clustered, upper ones solitary and sessile; spikelets acute, 3-4 mm. long ; lowest glume $1 \mathrm{~mm}$. long, 1-3-nerved; 2nd and 3rd glumes nearly equal, 5-7-nerved, the 3rd with a long palea; fruiting glume rugose, with a minute point.

Only known from Bentham's record, "near Lake Eyre."

*2. P. sanguinale, I. Summer Grass ; Crab Grass. Annual, with stems often creeping and rooting; leaves usually sprinkled with hairs; ligule short, jagged; spikes digitate or approximate at the summit of the stem, 3-10, slender, 5-15 cm. long; spikelets in pairs on unequal pedicels, $3 \mathrm{~mm}$. long, lowest glume minute; the 2nd 3 -nerved, half as long as the 3rd, which is 7-nerved and ciliate; fruiting glume smooth. Mar.

Mostly in cultivated land and probably introduced here ; almost cosmopolitan. Dec.-

3. P. distachyum, L. Glabrous perennial with flat leaves and short, ciliate ligule ; spikes few, distant, finally deflexed or spreading, $2-5 \mathrm{~cm}$. long, bearing the alternate spikelets in 2 rows along one side of the rhachis; spikelets $5 \mathrm{~mm}$. long, acute; lowest glume broad, not half as long as the spikelet; 2nd and 3rd glumes equal, 3-nerved; fruiting glume 3-nerved, transv ersely and finely rugose.

Far North. Flowering chiefly in summer.

4. P. decompositum, R. Br. Perennial, glabrous or with long spreading hairs on the main rhachis and upper leaf-sheaths; ligule short, ciliate; panicle rather large, at first compact, afterwards loose and spreading, with numerous slender divided branches, the lower ones clustered, or alternate and distant; spikelets on capillary pedicels, acuminate, $3 \mathrm{~mm}$. long, often purplish; lowest glume truncate, barely $\frac{1}{3}$ the length of 
the spikelet, 3-nerved ; 2nd and 3rd glumes equal, 7-9 nerved, the 3rd enclosing a palea ; fruiting glume smooth, shining, 5-7 nerved.-P. Whitei, J. M. Black.

Far North; usually growing on flooded land. Aug.-Apl.

Plate 1.-1, upper part of panicle-branch ; 2, base of leaf-blade ; 3, spikelet ; 4, 3rd glume with palea; 5, fruiting glume.

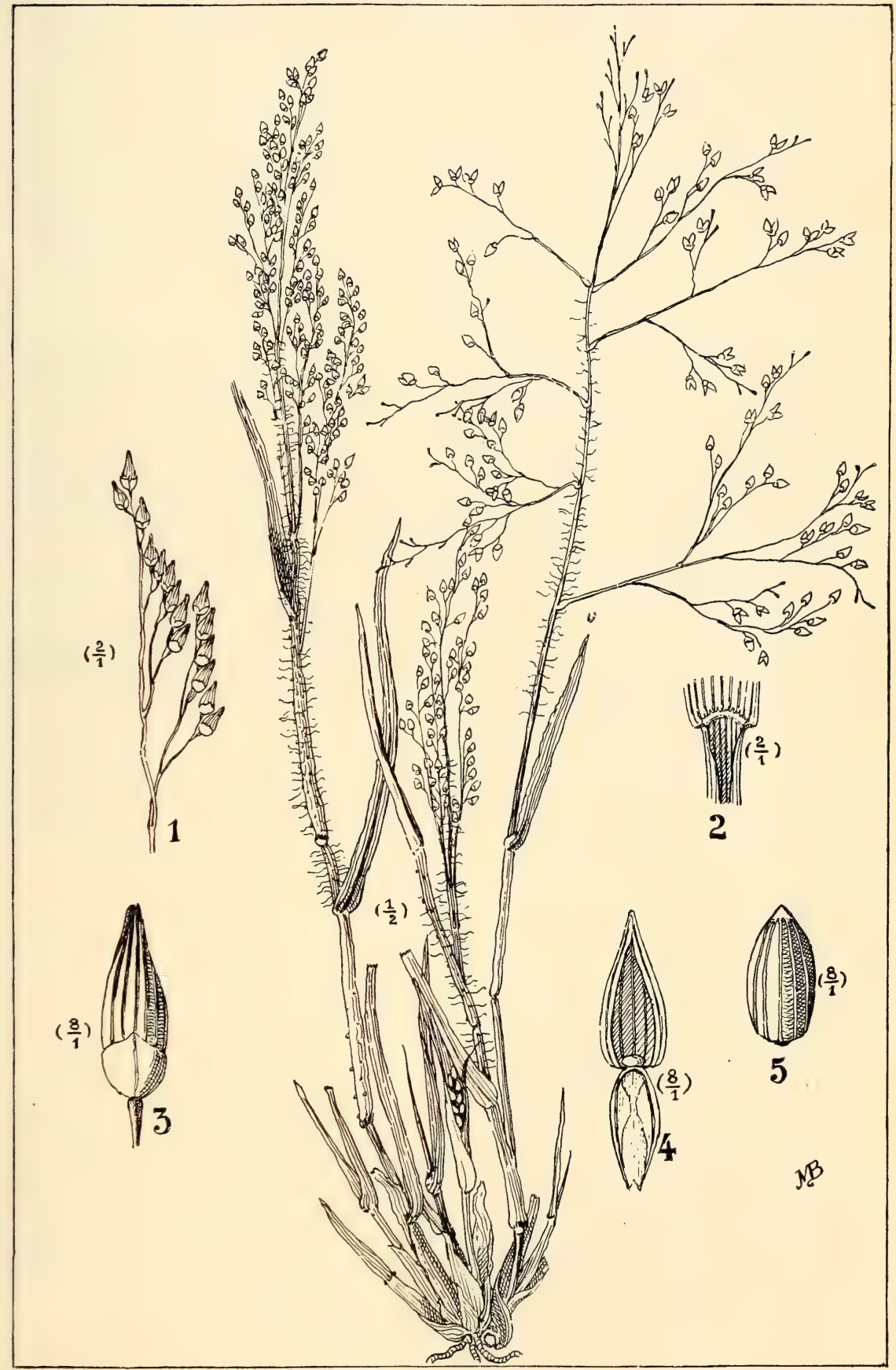

Plate 1.-Panicum decompositum, $\mathrm{R} \mathrm{Br}$. 
5. P. prolutum, F. v. M. Rather rigid glabrous perennial; leaves glaucous, with a conspicuous oblong ligule jagged at summit, not ciliate ; panicle as in the preceding species, the lower branches clustered; spikelets on capillary pedicels, turning purple, acute, 3-4 mm. long; lowest glume $\frac{3}{4}$ the length of the spikelet, obtuse, 5-nerved; 2 nd and 3rd equal, 7-9 nerved, no palea in the 3rd; fruiting glume smooth and shining.

Most parts of the State, usually growing near water. Oct.-Apl.

6. P. effusum, R. Br. A tussock grass $20-50 \mathrm{~cm}$. high ; lower leaves hairy and sometimes the upper ones also, but the latter are usually glabrous outside, although always silkybearded at base of sheath, hairs sometimes seated on tubercles ; ligule short, silky-ciliate ; panicle rigid, large and spreading, the divided branches alternate or clustered; spikelets $2-2 \frac{1}{2} \mathrm{~mm}$. long, acuminate, purplish, distant on capillary pedicels ; lowest glume acute, $\frac{1}{2}$ the length of the spikelet; the 2 nd and $3 \mathrm{rd}$ equal, 5-7 nerved, the 3rd enclosing a palea ; fruiting glume smooth and shining.

Most parts of the State, but chiefly in the dry North. Oct.-April.

7. P. reversum, F. v. M. Rather slender glabrous perennial with flat leaves; ligule short, ciliate; spikes (or simple panicle-branches) distant, short, erect then deflexed, articulate at base, with rigid bristles sheltering the lowest and terminal spikelets; spikelets few and alternate along one side of the flattened rhachis so as to appear in 1 row, 4-5 mm. long, ovoid-oblong; lowest glume $\frac{3}{4}$ as long as the spikelet, obtuse, 3-5 nerved; 2nd and 3rd glumes equal, 9-11 nerved; fruiting glume punctulate.

Flinders Range ; Far North and North-West. May-Jan.

8. P. gracile, R. Br. Glabrous perennial, with long, rather narrow leaves and ciliate ligule; spikes erect, the lower ones $2-2 \frac{1}{2} \mathrm{~cm}$. long, the upper ones much shorter, or the whole panicle reduced to short clusters; spikelets in 2 rows, $2-3 \mathrm{~mm}$. long ; lowest glume acute, half as long as the spikelet, 3-nerved; 2nd and 3rd equal, 5-nerved; fruiting glume acute, finely and transversely rugose.

Adelaide to Far North and North-West; Murray lands. Dec.-Apl.

9. P. pauciflorum R. Br. Low grass with scattered hairs; panicle scarcely exceeding the floral leaves, with few branches, each bearing 1-3 pedicellate spikelets, which are glabrous, acute, and $4 \mathrm{~mm}$. long : lowest glume $\frac{1}{2}$ as long as the spikelet, 5 -nerved ; 2nd and 3rd glumes equal; fruiting glume shorter, smooth and shining, shortly stalked.

Blood's Creek (Far North). Dec.-Aug.

10. P. divaricatissimum, R. Br. Perennial with the leaves flat and more or less silkypubescent and the ligule membranous and not ciliate : panicle branches spreading, simple, flexuose, $10-20 \mathrm{~cm}$. long, the lowest ones whorled; spikelets $2 \frac{1}{2} \mathrm{~mm}$. long, ovoid, acute, silky with usually purple hairs, in pairs, one on a longer pedicel than the other ; lowest glume under $1 \mathrm{~mm}$. long, ovate; the 2nd 3-nerved, the 3rd 5-nerved, equal; fruiting glume ovoid, smooth, acute.

Angaston; Murray and northern districts. Sept.-May.

11. P. coenicolum, F. v. M. Only differs from the preceding in the spikelets, which are oblong and larger $\left(3 \frac{1}{2}-4 \mathrm{~mm}\right.$. long), the silky hairs usually white ; lowest glume about $1 \mathrm{~mm}$. long, rigid; 2nd 3-5-nerved; the 3rd 5-7-nerved; fruiting glume ovoid-oblong, acute, smooth.

Flinders Range, usually growing near water, hence its specific name ("mud-inhabiting "). Sept.-May.

12. P. leucophaeum, H. B. et K. Near the two preceding species, with the silky, white or purple spikelets in pairs on unequal pedicels, but the panicle consisting of a few erect spike-like branches varying much in length; leaves glabrous or somewhat hairy ; ligule oblong, glabrous; spikelets $2-3 \mathrm{~mm}$. long; lowest glume minute, obtuse; the 2nd 3-nerved, the 3rd 5-nerved, equal; fruiting glume smooth, acute.

Flinders Range; Far North and North-West. Oct.-May.

Var. monostachyum, Benth. Panicle reduced to a simple spike. Far North.

13. P. helopus, Trin. Stems with bearded nodes; leaves broadly lanceolate, flat, with loose sheaths, sometimes sprinkled with hairs; ligule short, ciliate; panicle of a few short simple branches or spikes, longer or shorter than the subtending leaf ; spiketets mostly in pairs, acute, $4 \mathrm{~mm}$. long, glabrous or rarely hairy, on short unequal pedicels ; lowest glume broad, 3-nerved, $\frac{1}{3}$ the length of the spikelet; 2nd glume 7 -nerved, the 3rd 5-nerved, inclosing a palea and rarely a male flower also, the 2nd and 3rd equal; fruiting glume transversely rugulose, terminating in a short point.

Far North. Nov.-May.

14. P. Gilesii, Benth. Near the preceding, but the lowest glume is covered with long hairs, and the 3rd glume is ciliate with long spreading hairs.

The type is recorded from Charlotte Waters, in the Northern Territory, just beyond our border, so that the species probably occurs in our Far North.

$P$. argenteum, R. Br. With short spikes more distant than those of the last 2 species and spikelets crowned with a tuft of long silvery hairs, lowest glume small and fruiting glume smooth, has been found in the MacDonnell Ranges, N.T., and may also grow in our adjoining districts. 
* 15. P. crus-galli, L. Cockspur Grass ; Barnyard Grass. Annual with ascending stems, glabrous except the inflorescence ; leaves broad and long, without a ligule ; panicle contracted, of numerous sessile suberect spikes; spikelets crowded in 4 irregular rows on one side of the bristly rhachis of the spike, ovoid, acute, $3-3 \frac{1}{2} \mathrm{~mm}$. long, with bristly hairs on the nerves ; lowest glume broad, 3-nerved, not half as long as the spikelet; 2nd and 3rd glumes equal, mucronate or awned, the 2nd 5-nerved, the 3rd 7-nerved and enclosing a palea; fruiting glume smooth and shining.

A weed in most places; almost cosmopolitan. Dec.-Apl.

\section{SETARIA, Beauv.}

(Latin seta, a bristle: the spikelets are surrounded by stiff bristles.)

Spikelets with the bisexual flower and sometimes a male one below it, crowded in a spikelike panicle; outer glumes 3 , the 1st small, and the 2nd usually shorter than the 3rd ; flowering glume and palea of Panicum. Spikelets subtended by a unilateral cluster of persistant scabrous bristles.

A. Spikes rather short and dense.

Flowering glume strongly rugose ............. S. glauca 1 .

Flowering glume almost smooth ............. S. viridis 3 .

A. Spikes longer and appearing whorled.

Teeth of bristles reflexed ................. S. ve ticillata 2 .

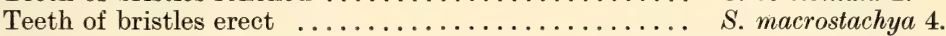

* 1. S. glauca, (L.), Beauv. Erect, pale-green annual; ligule of hairs and sometimes there are also long hairs near base of leafsheath; panicle spikelike, dense, $2-8 \mathrm{~cm}$. long ; bristles yellow or reddish-yellow, denticulate with erect teeth, several at the base of each spikelet, 2nd glume shorter than the 3rd, which contains a palea; fruiting glume transversely wrinkled.

Settled districts and probably introduced there. Dec.-Apl.-Temperate and subtropical countries.

* 2. S. verticillata (L.), Beauv. Resembles the preceding, the panicle to $10 \mathrm{~cm}$. long and not so dense, expecially near the base, where the spikelets appear as if whorled; bristles green or purplish during flowering, 1-3 below each spikelet and with the small teeth pointed downwards along the bristle ; 2nd and 3rd glumes almost equal and as long as the flowering glume, which is almost smooth, or rugulose under the lens.

Settled districts. Dec.-Mar.-Temperate and subtropical countries.

* 3. S. viridis (L.), Beauv. Closely resembles $S$. glauca, with a similar compact panicle, and several bristles with erect teeth, but the fruiting glume is shining and almost smooth, and the 2nd and 3rd glumes are nearly equal; leafsheaths ciliate, with rather long hairs near the summit.

River Murray district and South-East. Dec.-Apl.-Temperate and subtropical countries.

4. S. macrostachya, H. B. et K. Resembles S. verticillata, but has stouter stems and longer though slender spikelike panicles $(6-20 \mathrm{~cm}$.), bristles 1 or 2 under each spikelet and with erect teeth; fruiting glume rugulose under the lens.

From Farina northwards. Spring.

\section{CENCHRUS, I.}

(Kenkhros, Greek name for Millet.)

* 1. C. tribuloides, L. Bur Grass. Glabrous annual ; leafsheaths loose ; ligule short, ciliate; spike terminal $5-10 \mathrm{~cm}$. long; spikelets sessile, with 1 bisexual flower, singly or 2 together within a globular pubescent involucre of numerous bristles, united so as to form in fruit a hard bur about $8 \mathrm{~mm}$. long, beset with barbed spines; outer glumes 3 , the lowest small; flowering glume and palea of Panicum.

A North American weed which appeared at Renmark and other places on the Murray about 1910. Dec.-Mar.

\section{PENNISETUM, Rich.}

(Latin penna, a feather; seta, a bristle : alluding to the plumose bristles.)

* 1. P. villosum, R. Br. Perennial with narrow serrulate leaves; panicle cylindrical, about $5 \mathrm{~cm}$. long; spikelets with 1 fertile flower, solitary or $2-5$ together, each spikelet surrounded by an involucre of long slender bristles, plumose in the lower half, the peduncle falling off with the spikelets and bristles; outer glumes 3, the 1st and 2nd small, the 3rd containing a male flower; flowering glume with a bisexual flower.

An ornamental grass which has become naturalised near towns.-Abyssinia. Summer.

\section{PLAGIOSETUM, Benth.}

(Greek plagios, oblique ; Latin seta, a bristle : alluding to the unilateral bristles.)

1. P. refractum (F. v. M.), Benth. Glabrous grass, with narrow leaves and a ligule of silky hairs; spikelets with 1 fertile flower, the upper spikelets solitary with flat pedicels 
articulate at base, the lower ones 1-4 (or less by abortion), arranged on flat paniclebranches, the lateral spikelets pedicellate, the 1 or 2 central ones on much shorter pedicels ; a stalked involucre of several long bristles rising from the pedicel on one side of most of the spikelets, or the pedicel bearing an involucre but no spikelet; the panicle-branch (or peduncle) finally reflexed and falling off with the spikelets and involucre; spikelet $7 \mathrm{~mm}$. long; outer glumes 3, many-nerved, the first half as long as the spikelet; fruiting glume and palea of Panicum.

Cooper's Creek to the west of Innamincka. Aug.-Dec.

\section{CHAMAERAPHIS, R. Br.}

(Greek khamai, dwarf ; rhaphis, a needle ; alluding to the terminal bristle.)

1. Ch. spinescens (R. Br.), Poir. Stems creeping; upper leaves flat; ligule of hairs ; panicle short, with slender flexuose branches, which terminate in a stiff bristle or awn rising below the last of the few and distant spikelets; spikelets narrow, acuminate, about $6 \mathrm{~mm}$. long; lowest glume minute, truncate, the 2nd tapering into a long point, the 3rd shorter and containing a male flower; flowering glume usually holding only a female flower and not hardened as in Panicum.-Panicum spinescens, $\mathrm{R} . \mathrm{Br}$.

In or near water, River Murray.

Stenotaphrum dimidiatum (L.), Brongn. (Buffalo Grass), with twin spikelets on the broad rhachis of a solitary spike, is a popular lawn-grass, which has escaped here and there, but scarcely appears able to establish itself. -S. americanum, Schrank.

\section{SPINIFEX, L.}

(Latin, "thorn-maker": alluding to the pungent leaves of the Asiatic species first described.)

Spikelets dioecious, those of the male plant with 2 male flowers and arranged in clustered spikes; those of the fertile plant with 1 female or bisexual flower and an imperfect one below it, and arranged in globular heads; outer glumes 3 (including that of the lower male or imperfect flower); flowering glume and palea hardened round the grain ; ligule a ring of hairs.

Heads large ; silky grass ................. S. hirsutus 1.

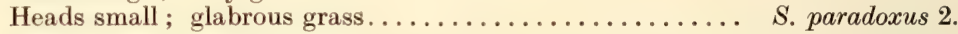

1. S. hirsutus, Labill. Perennial, with stout creeping stem ; leaves long, silvery-silky ; spikes of male plant in terminal or axillary clusters subtended by long leafy bracts; rhachis of each spike produced in a long awn; spikelets of fertile plant numerous, solitary at the base of an awn-like rhachis $10-15 \mathrm{~cm}$. long, the whole forming a large bristly globular head, which falls off the peduncle when ripe and is blown by the wind; glumes nearly equal.

A good sandbinding grass along our coasts. Nov.-Jan.

2. S. paradoxus (R. Br.), Benth. Cane-grass. Glabrous plant with long rigid spreading branching stems, creeping at base; heads of spikelets small (about $1 \frac{1}{2} \mathrm{~cm}$. diameter); male spikelet $6 \mathrm{~mm}$. long, the 2 lowest glumes much shorter than the 3rd and 4th ; spikelets of fertile plant enclosed in irregularly winged bracteoles and surrounded by broad bracts ; 3 outer glumes nearly equal, many-nerved, the 3rd with a palea.

Also a sandbinder, Far North and North-East. June-Nov.

2. Spikelets 1-to-many-flowered, the rhachilla usually jointed above the 2 outer glumes, but the pedicel not jointed below them so that the outer glumes persist on the pedicel after the flowering glumes have fallen off. Alopecurus and Polypogon are exceptions in which the 2 lowest empty glumes are supposed to be obsolete.

Tribe 5. Phalarideae. Spikelets pedicellate, with 1 fertile flower and 4 empty outer glumes; palea with the 2 nerves placed very close together or sometimes with only 1 nerve.

\section{EHRHARTA, Thunb.}

(After F. Ehrhart, a Swiss botanist.)

Spikelets 1-flowered, paniculate; empty glumes 4, the 2 outer ones persistant; the 3rd and 4 th bearded and pitted at base; the flowering glume shorter than the others; stamens 4-6; the 2 nerves of the palea close together.

Annual; 2 outer glumes small ................. E. longiflora 1.

Perennial; 2 outer glumes large ................ E. villosa 2.

*1. E. longiflora, Sm. Glabrous annual; leaves flat; panicle loose, 1 -sided, $3-10 \mathrm{~cm}$. long; spikelets $10-18 \mathrm{~mm}$. long on capillary pedicels ; 2 outer glumes small, acuminate, turning purplish ; 3rd and 4 th hard and shining, tapering into a short, stiff awn ; stamens 4-6.

Settled districts. "Sept.-Nov.-South Africa. 
*2. E. villosa, Schult. f. var. maxima, Stapf. Glabrous perennial with rigid ascending stems up to $1 \mathrm{~m}$. high ; leaves inrolled on margin ; spikelets about $15 \mathrm{~mm}$. long on capillary pedicels forming a narrow panicle, sometimes almost reduced to a raceme; 1st and 2nd glumes 9-12 mm. long, 5-7-nerved, ciliate; 3rd and 4th glumes 12-13 mm. long, villous, with a mucro or awn 2-3 mm. long; stamens 6 .

Planted as a sandbinder and established at Brighton and other places on the coast. Oct.-Jan.-South Africa.

\section{MICROLAENA, R. Br.}

(Greek mikros, small ; laina or khlaina, cloak : alluding to the 2 minute outer glumes.)

1. M. stipoides, (Labill.), R. Br. Slender perennial, with narrow almost glabrous leaves; spikelets 1-flowered, narrow, $10 \mathrm{~mm}$. long without the awns, pedicellate in a narrow panicle; 1st and 2nd glumes minute, unequal, persistant; 3rd and 4th rigid, empty, 5-7-nerved, tapering into fine awns longer than themselves, apparently stalked, with a tuft of hairs at base; flowering glume shorter; palea membranous, 1-nerved; stamens 4.-Ehrharta stipoides, Labill.

Mount Lofty Range; Kangaroo Island; South-East. Nov.-Jan.

\section{PHALARIS, L.}

(Old Greek name, probably from phalos, shining : alluding to the shining appearance of the fruiting glume.)

Spikelets 1-flowered, compressed laterally, arranged in dense spikelike panicles ; empty glumes normally 4 , the 2 outer the longest, persistent, 3 -nerved, the keel more or less winged; 3rd and 4th glumes small, scale-like; flowering glumes much shorter than the 1st and 2nd, 5-nerved; palea keeled, with 1 ciliate nerve; ligule membranous, glabrous.

A. Panicle cylindrical $\ldots \ldots \ldots \ldots \ldots \ldots \ldots \ldots \ldots \ldots \ldots$ Ph. minor 1.

A. Panicle ovoid.

Panicle $2 \frac{1}{2}-4 \mathrm{~cm}$. long ; wing blunt ............ Phanariensis 2.

Panicle $7-10 \mathrm{~cm}$. long; wing pointed .......... Paradoxa 3.

* 1 Ph. minor, Retz. Glabrous annual ; panicle oblong-cylindrical, 3-6 cm. long ; 2 outer glumes with a narrow scarious dorsal wing; 3rd glume wanting; 4th glume bristle-like, $\frac{1}{2}$ as long as the flower; flowering glume hairy.

Widely spread throughout the settled districts as far as the Flinders Range and the Murray lands. Sept.-Dec.-Mediterranean region.

* 2. Ph. canariensis, L. Canary-grass. Differs from the preceding in the ovoid or ovoid-oblong panicle; wing of 2 outer glumes broader, almost entire, obliquely truncate ; 3rd and 4th glumes equal, $\frac{1}{2}$ as long as flower; flowering glume hairy.

Rare in settled districts. Sept.-Nov.-Mediterranean region.

* 3. $\mathrm{Ph}$. paradoxa, L. Differs in the long oblong-ovoid panicle, clasped at the base by the sheath of the uppermost leaf; 2 outer glumes awned and the wing prolonged upwards into a point; 3rd and 4th glumes minute, equal; flowering glume almost glabrous.

Hindmarsh Valley; Kingscote, K.I. Nov -Dec.-Mediterranean region.

\section{ANTHOXANTHUM, L.}

(Greek anthos, flower ; xanthos, yellow : colour of the panicle after flowering.)

* 1. A. odoratum, L. Scented vernal grass. Perennial with hairy leafblades; spikelets 1-flowered, compressed laterally, arranged in a spikelike panicle which is 4-6 cm. long ; empty glumes 4 , the lowest $\frac{1}{2}$ the length of the 2 nd: the 3 rd and 4 th smaller, villous, with dorsal awns; flowering glume still shorter, membranous, glabrous ; stamens 2.

Mount Lofty Range. Sept.-Dec.-Europe.

Tribe 6. Agrostideae. Spikelets 1 -flowered, pedicellate; outer empty glumes 2 ; flowering glume usually awned; palea 2-nerved.

\section{AMPHIPOGON, R. Br.}

(Greek amphi, both; pōgon, beard: because both the flowering glume and palea have ciliate awns.)

1. A. strictus, R. Br. Perennial growing in tussocks, with slender erect stems, subulate leaves and ligule of hairs; spikelets 1-flowered, almost sessile in a dense cylindrical spikelike panicle which is $1 \frac{1}{2}-4 \mathrm{~cm}$. long; 2 outer glumes thin, subequal, 3-nerved, about $4 \mathrm{~mm}$. long; flowering glume exceeding them by its 3 short rigid ciliate awns or lobes; palea also deeply divided into 2 similar awns; styles united near the base.

Most parts of the State. Sept.-Dec.

Var. setifer, Benth. Spike tending to ovoid; outer glumes conspicuously ciliate ; awns longer and more shortly ciliate.

Mount Lofty Ranges. 


\section{ARISTIDA, L.}

(Latin arista, an awn : alluding to the trifid awn.)

Spikelets 1-flowered, paniculate; outer glumes 2, narrow, keeled, persistant ; flowering glume rigid, mounted on a short callus and terminating in a 3 -fid awn; palea small; hilum linear. Glabrous erect perennial tussock grasses, with subulate leaves, the paniclebranches bearing very few spikelets. Often known as Wire-grasses.

A. Awn with a long undivided basal part, which is spirally twisted and articulate on the glume.

Undivided part about $3 \frac{1}{2} \mathrm{~cm}$. long ............. stipoides 1 .

Undivided part about $1 \frac{1}{2} \mathrm{~cm}$. long $\ldots \ldots \ldots \ldots \ldots \ldots$ A. arenaria 2.

A. Awn divided to the glume into 3 branches.

B. Panicle short, broad and dense ; 2 outer glumes very

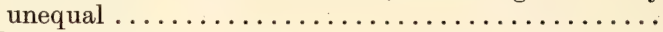

B. Panicle narrow, compact or rather loose; outer glumes nearly equal.

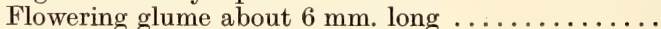

Flowering glume about $9 \mathrm{~mm}$. long $\ldots \ldots \ldots \ldots \ldots \ldots \ldots \ldots$ A. calycina 5 .

1. A. stipoides, R. Br. Panicle narrow, with erect branches; lowest glume $10 \mathrm{~mm}$. long; 2nd glume nearly double as long; awn below the branches about $3 \frac{1}{2} \mathrm{~cm}$. long; branches capiliary, $4-5 \frac{1}{2} \mathrm{~cm}$. long.

Far North. Sept.-Nov.

2. A. arenaria, Gaudich. Mulga Grass. Shorter than the preceding with ascending slender stems; panicle narrow, often reduced to a raceme, purplish ; outer glumes as in the preceding, but less rigid; awn below the branches $1 \frac{1}{2}-2 \frac{1}{2} \mathrm{~cm}$. long; branches usually 4-5 $\frac{1}{2} \mathrm{~cm}$. long.

Central and Murray districts; Far North and North-West. June-Nov.

3. A. Behriana, F. v. M. A short ascending grass with thick rootstock and loose leafsheaths, the uppermost blade sometimes as long as the panicle ; panicle only $5-8 \mathrm{~cm}$. long, dense and broad, purplish ; lowest glume 7-9 mm. long, the 2nd 14-18 mm. long ; flowering glume $8-10 \mathrm{~mm}$. long, with 3 capillary sessile awns, $3-4 \mathrm{~cm}$. long.

From Adelaide northwards to the Flinders Range; Murray Lands. Sept.-Dec. Usually in moist ground.

4. A. ramosa, R. Br. Panicle narrow, $6-12 \mathrm{~cm}$. long, with erect branches ; lowest glume 5-6 mm. long, 2nd a little longer ; flowering glume 5-6 mm. long, with a very short callus ; awns sessile, spreading, 8-14 mm. long.

Flinders Range; Far North. Aug.-Oct.

5. A. calycina, R. Br. Very like the preceding, but the lowest glume is $7-8 \mathrm{~mm}$. long and the 2nd is $8-10 \mathrm{~mm}$. and equals or slightly exceeds the flowering glume which is about $9 \mathrm{~mm}$. long and is sometimes slightly twisted above the part containing the grain; awns continuous with the flowering glume, $15-35 \mathrm{~mm}$. long; panicle to $20 \mathrm{~cm}$. long.

Flinders Range; Far North and North-West. May-Jan.-Both these species are very near A. Adscensionis, L. (A. depressa, Retz.), and should perhaps be united with it as varieties.

\section{STIPA, L.}

Greek stype tow : alluding to the fibre obtained from Esparto Grass (S. tenacissima, L.)

Spikelets 1-flowered, usually paniculate; outer glumes 2, membranous, keeled, persistant, often turning purplish; flowering glume usually shorter, convolute, finally hardened, mounted on a short hairy callus, with a long terminal awn, which is kneed and spirally twisted below the knee ; palea enclosed in the flowering glume; anthers usually tipped with bristles; lodicules fleshy, oblong; grain fusiform ; hilum linear. Perennial grasses ; the leaves inrolled, at least when dry.

Spear-grass, Corkscrew-grass. Injurious, when ripe, to sheep, owing to the sharp, penetrating callus of the fruiting glume.

A. Flowering glume glabrous or nearly so.

Panicle-branches feathery with long hairs ......... S. elegantissima 1.

Panicle-branches with short hairs ............ S. Tuckeri 2.

A. Flowering glume silky-hairy.

B. Ligule glabrous, often long.

C. Flowering glume shortly bilobed at summit.

Leaves long; spikelets in a panicle ............

Leaves almost absent; spikelets in a short raceme

S. teretifolia 3.

S. Muelleri 4.

C Flowering glume entire at summit.

D Leaves nrolled-filiform; stems slender.......... S. setacea 5 .

D. Lower leaves flat, ribbed.

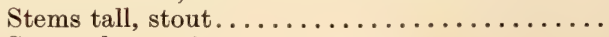

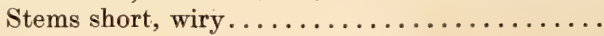

S. acrociliata 6

S. scelerata 7 
B. Ligule ciliate.

E. Flowering glume shortly bilobed.

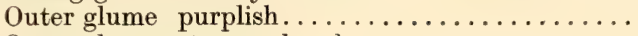
Outer glumes straw-colored ..............

E. Flowering glume entire or with microscopic lobes at summit.

F. One or both outer glumes usually truncate or toothed at summit.

Awn pubescent; flowering glume rather broad... Awn villous below bend; flowering glume narrow

S. eremophila 8 .

S. flavescens 9 .

Outer glumes acute, not toothed.

G. Stem stout; awn villous in 'ower part........

G. Stem slender; awn pubescent.

Fruiting glume broad, golden-brown .......

Fruiting glume narrow, whitish. . ........

S. pubescens 10 .

S. horrifolia 11.

S. semibarbata 12.

S. eremophila 8.

S. scabra 13.

1. S. elegantissima, Labill. Tall, glabrous grass; panicle large and very loose, the rhachis and branches plumose with long, spreading hairs; both outer glumes 3-nerved, the lower one longer and broader, $10-12 \mathrm{~mm}$. long, hairy, acuminate; flowering glume glabrous, shortly bilobed; awn $3-5 \mathrm{~cm}$. long, pubescent.

Most parts of the State except the South-East. Aug.-Dec.

2. S. Tuckeri, F. v. M. A small grass, with pubescent flattish leaves; panicle-branches shortly plumose; outer glumes short, acuminate; flowering glume glabrous.

Murray River (according to Tate's Flora, but his herbarium contains no specimens, and those in the Melbourne herbarium are only from the Lachlan and Darling district in New South Wales).

3. S. teretifolia, Steud. Slender, almost glabrous ; leaves very long, erect, filiform, rigid, almost pungent-pointed; ligule oblong, about $2 \mathrm{~mm}$. Iong, glabrous; panicle narrow, 12-20 cm. long; outer glumes equal, broad, acute, whitish, $15-20 \mathrm{~mm}$. long, the 1st 3-nerved, the 2nd 5-nerved; flowering glume 10-12 $\mathrm{mm}$. long, villous all over, with 2 lanceolate hairy lobes on each side of the awn, 2-3 mm. long; awn $3 \frac{1}{2}-4 \mathrm{~cm}$. long, finely pubescent, twice bent; anthers $6-8 \mathrm{~mm}$. long.

Sea-coast. Sept.-Nov.

4. S. Muelleri, Tate, Stems wiry, glabrous, leafless except for the small erect lamina; ligule short, glabrous; spikelets 1-3 on long pedicels, forming a short raceme ; outer glumes acute, subequal, 20-30 mm. long, the 1st 3-nerved, the 2nd 5-nerved; flowering

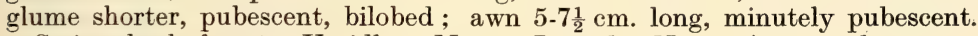

Stringybark forests, Uraidla; Mount Jagged. Nov. Apparently very rare.

5. S. setacea, R. Br. Stems slender; nodes minutely pubescent; leaves filiform; slightly scabrous; ligule rounded, glabrous; sheaths often bearded at orifice ; panicle rather narrow; outer glumes hyaline, acute, subequal, narrow, the 1st sub-3-nerved, $9-13 \mathrm{~mm}$. long, the 2nd 3-nerved, $8-11 \mathrm{~mm}$. long; flowering glume 3-4 mm. long, narrow, pubescent, with longer hairs in the lower half ; awn very slender, $5-6 \mathrm{~cm}$. long.

Adelaide plains; South-East. Sept. Dec.

Var. latiglumis. Ligule $3.5 \mathrm{~mm}$. long; outer glumes broad, the 2nd sub-5-nerved; flowering glume broad, contracted and shortly bearded at summit; awn $2 \frac{1}{2}-3 \frac{1}{2} \mathrm{~cm}$. long, rather stout, twice bent.

Belair ; Minnipa, E.P.

6. S. acrociliata, Reader. Stems stout, rather tall; nodes glabrous; leaves long, ribbed, rigid, glabrous, flat or the upper ones subulate, often reflexed; ligule 5-7 mm. long, glabrous, truncate; panicle large, with long spreading capillary branches ; outer glumes hyaline, straw-colored, unequal, the 1 st $10-13 \mathrm{~mm}$. long, sub-3-nerved, acute, the 2nd $8.9 \mathrm{~mm}$. long, 3-nerver, obtuse or notched, both strongly ciliate at summit ; flowering glume $4 \mathrm{~mm}$. long, pubescent, entire ; palea ciliate ; awn slender, 6-8 cm. long.

Enfield; Murray lands; Flinders Range; North-West; South-East. Sept.-Jan.

7. S. scelerata, Behr. Erect grass about $30 \mathrm{~cm}$. high, glabrous except sometimes the lower leafsheaths; stems rigid, wiry ; lower leaves flat, stiff, prominently ribbed, finally inrolled; ligule about $5 \mathrm{~mm}$. long, glabrous, jagged at summit ; panicle rather compact; outer glumes subequal, hyaline, acuminate, the 1 st $7-8 \mathrm{~mm}$. long, sub-3-nerved; the 2nd 6-7 mm. long, 3-nerved ; flowering glume nearly $4 \mathrm{~mm}$. long, pubescent or subvillous : awn slender, pubescent, $4 \frac{1}{2}-7 \mathrm{~cm}$. long. $-S$. setacea. R. Br. var. latifolia, Benth.

Flinders Range. Sept.-Dec.

8. S. eremophila, Reader. Stems slender, erect ; nodes more or less pubescent ; leaves subulate, almost filiform, glabrous, or the radical ones scabrous; ligule short, ciliate, accompanied usually by longer hairs at the orifice of the sheath; panicle loose ; 2 outer glumes hyaline, unequal, asute, often purplish, the 1 st $15-22 \mathrm{~mm}$. long, prominently 
3-nerved, the 2nd $12-14 \mathrm{~mm}$. long, sub-5-nerved; flowering glume broad, 4-6 $\mathrm{mm}$. long, villous with golden-brown hairs ; palea with similar hairs on the back ; callus $2 \frac{1}{2} \mathrm{~mm}$. long; awn $5-8 \mathrm{~cm}$. long, twice bent, distinctly pubescent below the bends.

Most parts of the State. Aug.-Dec. The type, which came from Western Victoria, has 2 distinct hairy lobes at the summit of the flowering glume. but in our northern specimens these lobes are often almost obsolete. Very near S. flavescens, from which it differs in the longer and colored outer glumes, the much longer awn, the looser panicle, and the usually inland habitat.

Var. dodrantaria. Flowering glume narrower; awn $6-7 \mathrm{~cm}$. long, distinctly pubescent or subplumose almost to the summit.

Near Birksgate Range.

9. S. flavescens, Labill. Stems slender, with pubescent nodes ; leaves inrolled, filiform, glabrous or the lower ones scabrous with pubescent sheaths ; ligule short, ciliolate ; panicle narrow, dense ; outer glumes rather broad, unequal, yellowish, acute, the 1st about 12 $\mathrm{mm}$. long, prominently 3 -nerved, the $2 \mathrm{nd} 9 \mathrm{~mm}$. long, 5-nerved ; flowering glume 5-6 mm. long, brown, villous, with 2 minute glabrous lobes at summit; awn 4-5 cm. long, slender, twice bent.

Sea coasts. Oct.-Dec.

10. S. pubescens R. Br. Variable grass; stems rather stout, with pubescent nodes ; leaves glabrous or pubescent, subulate, with a short ciliate ligule ; panicle rather loose ; outer glumes usually green and purplish, prominently nerved, one or the other more or less truncate and toothed at the hyaline summit, often with 1 long central tooth; 1st glume 10-16 mm. long, 3-nerved; 2nd glume 8-12 mm. long, sub-5-nerved; flowering glume rather broad, $5 \mathrm{~mm}$. long, lobeless or almost so, villous with whitish hairs; palea hairy

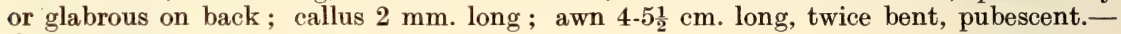
S. aristiglumis, F. v. M.

From Adelaide northwards to the Flinders Range; South-East. Sept.-Dec.

Var. semiglabra, Reader. Lower leaves rather hairy; lst glume, 20-25 mm. long; 2nd, 16-20 mm. long; flowering glume, $9 \mathrm{~mm}$. long; scantily villous; callus $3 \mathrm{~mm}$. ; awn $7.9 \mathrm{~cm}$. long, twice bent above the middle, comparatively stout.

Penola.

Var. comosa. Outer glumes as in the type, but sometimes longer; flowering glumes broad, about $4 \mathrm{~mm}$. long, silky villous, with a tuft of white hairs at the summit about as long as the flowering glume; awn $2 \frac{1}{2} .4 \mathrm{~cm}$. long; leafblades usually scabrous with short spreading hairs.

Marino; Jamestown; Melrose ; Moolooloo.

11. S. horrifolia, J. M. Black. Stems erect, rigid; leaf blades ribbed, pubescent with short spreading hairs; blades at first flat, finally subulate and rigid; lower sheath softly villous; ligule short, ciliate; uppermost sheath inflated and usually embracing the base of the somewhat loose panicle, $15-30 \mathrm{~cm}$. long; outer glumes purplish, truncate, 1-3toothed at summit, the 1 st $8.10 \mathrm{~mm}$. long, 3-nerved, the 2nd a little shorter, 5-nerved; flowering glume entire, 3-4 mm. long, narrow, with white hairs; awn 4-7 cm. long, subplumose below the bend, pubescent above.

From Pinnaroo westward to the Nullarbor Plain. Oct.-Jan. Very near S. Luehmannii, Reader, from Western Victoria, but the latter is a stouter and taller grass, with longer and more densely hairy leaves. It may be, however, that ours is a dry-country form, and, if so, Reader's name has priority.

PLATE 2.-1, outer glumes; 2, flowering glume, palea and awn; 3, lodicules, pistil and stamens ; 4, sumuit of leafsheaf; 5, anterior face of grain, showing embryo $(e)$; 6, posterior face, showing linear hilum $(h)$.

12. S. semibarbata, R. Br. A tall stout grass, sometimes 1-1 $\frac{1}{2} \mathrm{~m}$. high ; nodes pubescent ; upper leaves subulate; orifice of sheath bearded; ligule short, ciliate; panicle long, rather contracted; outer glumes subequal, whitish, acute or torn at summit, the lst $15-20 \mathrm{~mm}$. long, 3-nerved, the 2nd $12-17 \mathrm{~mm}$. long, 3-5 nerved ; flowering glume narrow, $5.6 \mathrm{~mm}$. long, with whitish hairs, lobeless; callus $3 \mathrm{~mm}$. long; awn $5.9 \mathrm{~cm}$. long, twice bent, more or less plumose in lower half.

Southern districts; Eyre Peninsula; South-East. Sept.-Dec.

13. S. scabra, Lindl. Common Spear grass. Stems erect, usually slender, variable in height, with glabrous nodes; leaf blades filiform, sometimes scabrous with short hairs; ligule short, ciliolate, usually produced into 1 or 2 bearded lobes or auricles decurrent along the margin of the sheath; panicle unilateral, rather narrow, but very loose when in flower, sometimes embraced at base by the dilated sheath of the uppermost leaf ; outer glumes subequal, acute, hyaline, turning purple, the 1st 11-12 mm. long, sub-3-nerved, the 2nd 9-10 mm. long, sub-5-nerved; flowering glume narrow, pubescent, 3-4 mm. long, lobeless or with 2 very minute glabrous lobes; callus $1-1 \frac{1}{2} \mathrm{~mm}$. long; awn $4 \frac{1}{2}-8 \mathrm{~cm}$. long very slender and hairlike, pubescent under lens.

Common in almost all parts of the State. Aug.-Dec. 
Var. barbata, Benth. Stems slender; leaf-sheaths densely bearded at orifice. Dry districts.

Var. auriculata, J. M. Black. Stems slender or rather stout; ligule extended on one side into a conspicuous lobe or auricle; lower leaf-sheaths pubescent. Dry districts.

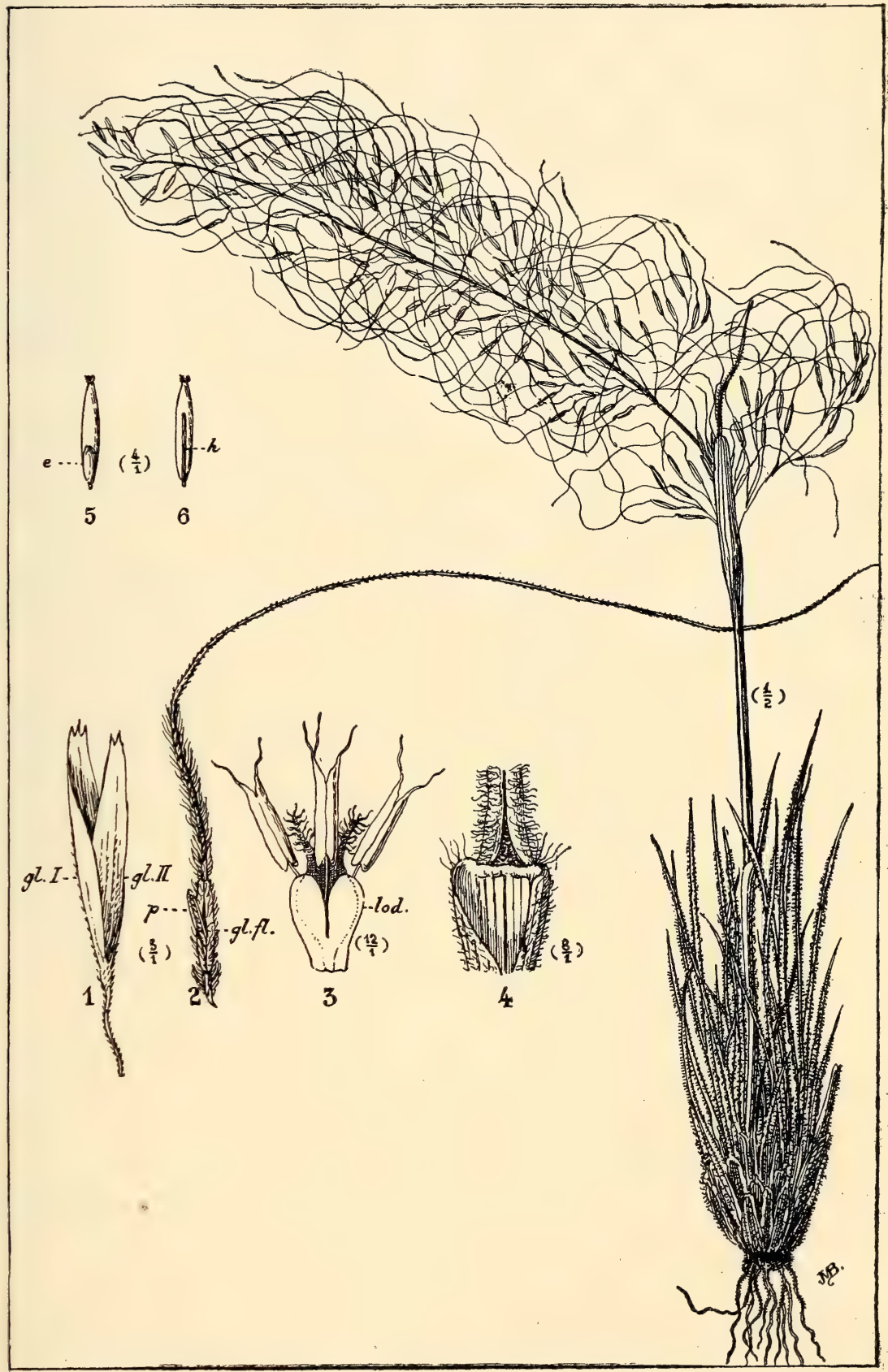

Plate 2.--Stipa horrifolia, J. M. Black.

27. ORYZOPSIS, Michaux.

(Greek oryza, rice: opsis, resemblance.)

*1. 0. miliacea (L.), Aschers. et Schweinf. Many-flowered Millet-grass. Glabrous perennial, with rigid stems and flat glossy leaves ; spikelets 1 -flowered, small, numerous, 
in a large spreading panicle; outer glumes 2, membranous, longer than the flowering glume, which has a straight, terminal, deciduous awn twice its length rising from its notched summit ; fruiting glume hardened and shining.

An ornamental grass, naturalised in places. Oct.-Feb.-Mediterranean region.

\section{ECHINOPOGON, Beauv.}

(Greek ekhinos, hedgehog: pōgōn, beard : alluding to the bristly head.)

1. E. ovatus (Forst.), Beauv. Erect annual, with flat scabrous leaves; spikelets 1 flowered, in a dense bristly spikelike ovoid or oblong panicle, $2-4 \mathrm{~cm}$. long; outer glumes 2 , nearly $4 \mathrm{~mm}$. long, ciliate on the keel; flowering glume about the same length, with 2 acute lobes and a short straight awn rising between them; the flowering glume bearded at base, and the rhachilla produced into a short bristle behind the flower.

Mount Lofty Range; Kangaroo Island; South-East; Flinders Range. Oct.-Feb.

\section{ALOPECURUS, L.}

(Greek alōpex, a fox; oura, tail ; shape of the spike-like panicle.)

Spikelets 1-flowered, crowded into a dense spike-like panicle; outer glumes 2, equal, compressed-keeled, 3-nerved; flowering glume rather shorter, with a short dorsal awn bent and twisted below the bend; palea wanting; rhachilla of spikelet articulate below the outer glumes.

Outer glumes about $3 \mathrm{~mm}$. long, free almost to the base... A. geniculatus 1 .

Outer glumes about $6 \mathrm{~mm}$. long, united to the middle..... A. agrestis 2.

1. A. geniculatus, L Marsh Fox-tril. Glabrous perennial, with ascending stems; panicle cylindrical, slender, $3.5 \mathrm{~cm}$. long, the lower branches bearing $2-4$ spikelets; outer glumes 3-3 $\frac{1}{2} \mathrm{~mm}$. long, ciliate on the keel and lateral nerves with long hairs, almost free ; awn $5.8 \mathrm{~mm}$. long, inserted below middle of flowering glume.

Wet ground, Murray River; Far North. Sept.-Dec.

*2. A. agrestis, L. Slender Fox-tail. Glabrous annual; panicle cylindrical, slender, attenuated at both ends, $5-9 \mathrm{~cm}$. long, the branches usually bearing only 1 spikelet; outer glumes 6.7 $\mathrm{mm}$. long, shortly ciliate on keel, united to the middle; awn $10-12 \mathrm{~mm}$. long, inserted near base of flowering glume.

Crops and pasture in South-East. Sept.-Dec.-Europe; Northern Asia.

\section{SPOROBOLUS, R. Br.}

(Greek sporos, seed ; bolos, throwing: the seed is shed easily from the flowering glume and palea.)

Spikelets 1-flowered, awnless, in spikelike or loose panicles; outer glumes 2, persistent ; not exceeding the flower, faintly 1-nerved; flowering glume faintly 3-nerved, membranous; palea readily splitting between the 2 nerves; seed free within a very thin pericarp; hilum punctiform; stamens 2-3. Perennials.

A. Panicle spikelike.

2nd glume equal to flowering glume............ S. virginicus 1 .

2nd glume shorter than flowering glume $\ldots \ldots \ldots \ldots$ S. indicus 2 .

A. Panicle broadly pyramidal.

Spikelets sessile, crowded

Spikelets pedicellate, distant

S. actinocladus 3 .

S. Lindleyi 4 .

1. S. virginicus (L.), Kunth. Stems leafy, ascending from a thick, creeping, scaly rootstock ; leaves short, more or less sprearling, rigid, inrolled-subulate, almost distichous ; ligule very short, ciliate; panicle spikelike, lead-colored, $2.7 \mathrm{~cm}$. long; outer glumes keeled, the 1st $2 \mathrm{~mm}$. long, the 2 nd $3 \mathrm{~mm}$.; flowering glume similar to and about as long as the 2nd; pericarp only separable from grain when soaked.

Salt marshes and sandhills near the coast; also on salty soil inland up to the Far North.

Var. pallidus, Benth. Rootstock, stems and leaves usually, but not always, more slender than in the type; spike $3-10 \mathrm{~cm}$. long; spikelets slightly smaller and pale-colored. $-S$. Benthamii, Bailey.

River Murray ; Far North.

2. S. indicus, R. Br. Stems erect ; leaves mostly basal, rather long, finally inrolled ; ligule very short, ciliate; panicle spikelike, olive-green, often interrupted and slightly lobed near base, $8-20 \mathrm{~cm}$. long; spikelets acute ; outer glumes unequal and very delicate, the 1 st $\frac{1}{2}-\frac{3}{4} \mathrm{~mm}$. long. the 2 nd a hout twice as long ; flowering glume longer still (2-21 $\mathrm{mm}$.); grain truncate. almost quadrangular; pericarp loose.

Near Adelaide; South-East. June-Jan.-Both these species are found in many other warm countries.

Var. elongatus (R. Br.), Bailey. Panicle $15.30 \mathrm{~cm}$. long, interrupted in all its length, the branches spreading slightly when in flower, but clothed to the base with spikelets

Far North. 
3. S. actinocladus, F. v. M. Stems erect; leaves flat, glabrous or hairy, the blades ciliate on the margin with short rigid hairs; ligule very short, ciliate; panicle pyramidal, $5.12 \mathrm{~cm}$. long; branches spreading, the lower ones in rather distant whorls, all naked towards base; spikelets sessile or almost so, crowded in dense unilateral partial panicles on upper part of panicle-branches; outer glumes unequal, the 1 st about $1 \mathrm{~mm}$. long, the 2nd $1 \frac{1}{2} \mathrm{~mm}$. ; flowering glume nearly $2 \mathrm{~mm}$. ; pericarp loose.

Widely distributed over the Far North and North-West. June-Jan.

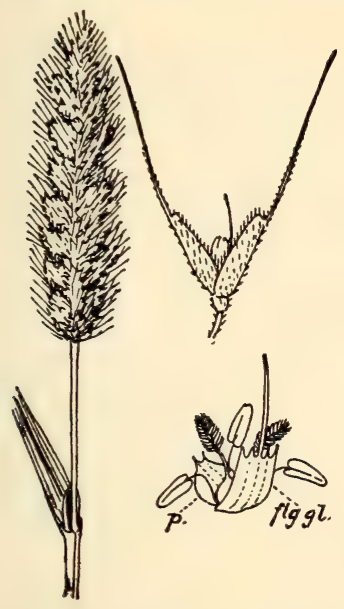

4. S. Lindleyi, Benth. Leaves scabrous-ciliate and often sprinkled with hairs seated on tubercles; panicle loose and broad, the lowest branches verticillate; spikelets distant, on capillary pedicels, $1 \frac{1}{2} \mathrm{~mm}$. long; glumes acute, the lst small and narrow, the 2nd as long as the flowering glume.

Far North. Summer.

\section{POLYPOGON, Desf.}

(Greek polys, many : pōgōn, a beard : alluding to the bristly panicle.)

* 1. P. monspeliensis, Desf. Beard-grass. Erect or ascending annual, with flat leaves and a long, glabrous ligule; spikelets $2.2 \frac{1}{2} \mathrm{~mm}$. long, 1-flowered, the pedicel articulate a little below the 2 outer glumes, which are equal, keeled, pubescent, notched, and with a terminal awn 2-3 times their length; flowering glume half their length, 4-toothed at summit and with a short, deciduous awn ; panicle spikelike, dense or somewhat lobed, bristly, varying from $1 \mathrm{~cm}$. long in dry situations to $12 \mathrm{~cm}$. in moist places.

FIG. 19.-Polypogon monspeliensis. Naturalised all over the State. Oct.-Jan,-Europe.

\section{AGROSTIS, L.}

(Greek agrostis, the name of a grass.)

Spikelets 1-flowered, laterally compressed, pedicellate, in a loose or contracted panicle ; rhachilla not produced into a bristle above the flower; outer glumes 2, keeled, awnless, persistent, nearly equal : flowering glume membranous, with or without an awn, glabrous or nearly so at base.

Panicle loose; palea $\frac{1}{2}$ as long as flowering glume ....... A. alba 1.

Panicle more compact; palea as long as flowering glume .. A. verticillata 2.

* 1. A. alba, L. Creeping Bent-grass. Perennial with creeping rootstock and flat leaves; panicle 5-20 cm. long, oblong, lobed, loose during flowering; spikelets $2 \mathrm{~mm}$. long; flowering glume $\frac{1}{1}$ shorter than the outer glumes, truncate, 4 -toothed, awnless ; palea $\frac{1}{2}$ as long.

Near water in southern districts. Oct.-May.-Europe.

* 2. A. verticillata, Vill. Differs from the preceding in the denser and shorter panicle (4-10 cm.); spikelets clothing the branches almost to the base; flowering glume $\frac{1}{2}$ as long as the outer glumes; palea as long as flowering glume.

Beside creeks all over the settled districts. Oct.-May.-Mediterranean region.

\section{CALAMAgROSTIS, Adans.}

(Latin calamus, a reed, prefixed to Agrostis.)

Differs from Agrostis in the presence: of a conspicuous tuft of hairs on the short rounded callus at the base of the flowering glume, associated with which is usually a bristle rising from the callus and at the back of the palea.

A. Panicle loose.

Awn present near middle of flowering glume . . . . . .

Awn absent; spikelet very small ..............

A. Panicle spikelike or slightly lobed.

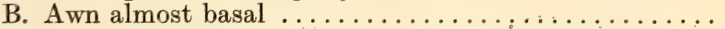
B. Awn attached near middle of flowering glume.
Bristle present; spikelet $5 \mathrm{~mm} . \ldots \ldots \ldots \ldots \ldots \ldots$.
Bristle absent; spikelet $4 \mathrm{~mm} . \ldots \ldots \ldots \ldots \ldots \ldots$.
C. quadriseta 3 .
C. densa 4 ,
C. minor 5 .

C. filiformis 1.

1. C. filiformis (Forst.), Pilger. Blown Grass. Glabrous grass, very variable in size, with flat leaves and long, glabrous ligule ; stem brittle; panicle very loose, usually large, with whorled spreading capillary divided branches; outer glumes acute $2 \frac{1}{2}-3 \frac{1}{2} \mathrm{~mm}$. long, rarely 4-5 $\mathrm{mm}$. long; flowering glume much shorter, membranous, truncate, 4-toothed, (the 2 outer teeth the longest), hairy on back, with a bent and twisted awn attached above 
or below the middle of the glume and about $5 \mathrm{~mm}$. long; tuft $\frac{1}{4}$ as long as flowering glume, and the plumose bristle about $\frac{1}{2}$ as long.-C. aemula, Steud. ; Deyeuxia Fosteri, Kunth.; D. plebeja, Benth.; Agrostis Solandri, F. v. M.

Common throughout the State. Sept.-Feb.

Var. Billardieri, Maid. et Betche. Outer glumes usually 6-7 mm. long, but not always longer than type; flowering glume glabrous, except that a few minute hairs are sometimes present near the summit.-Deyeuxia Billardieri, Kunth.

Sea-coasts and some distance inland.

2. C. aequata (Nees), J. M. Black. Leaves flat, narrow ; panicle loose, with spreading capillary branches, the lower whorled, the upper in pairs; outer glumes barely $2 \mathrm{~mm}$. long; flowering glume shorter, truncate, with 4 very short teeth and no awn; tuft $\frac{1}{4}$ as long as flowering glume; bristle short, plumose, palea as long as flowering glume.Deyeuxia aequata, Benth.

Only known from a single specimen in the Tate Herbarium, collected at Nelson, Glenelg River, close to our South-Eastern border. Resembles Agrostis hiemalis (Walt.), B.S. et P. (A. scabra, Willd.), which probably accounts for the inclusion of the latter species in Tate's Flora for the Mount Gambier district.

3. C. quadriseta (Labill.), Spreng. Glabrous perennial, sometimes rather tall ; leaves flat or finally inrolled; ligule long, truncate, glabrous; panicle dense and cylindrical, sometimes slightly lobed, $5-15 \mathrm{~cm}$. long; outer glumes narrow, acute, subequal, $3 \frac{1}{2}-5 \mathrm{~mm}$. long; flowering glume shorter, usually minutely scabrous, 4-nerved and with 4 teeth, of which the two inner are usually the longest; awn almost basal, included or shortly exserted beyond the outer glumes; tuft about $\frac{1}{4}$ as long as flowering glume; bristle usually represented by a minute ovoid or conical glabrous extension of the rhachilla and sometimes bearing an empty awned glume.-Deyeuxia quadriseta, Benth.; Agrostis quadriseta, $\mathrm{R}$. Br.

Mount Lofty Range; Kangaroo Island; Flinders Range. Oct.-Jan.

4. C. densa (Benth.), Maid. et Betche. Rather slender, glabrous grass ; leaves narrow ; ligule short, rounded, glabrous; panicle narrow but lobed towards the base, $8-16 \mathrm{~cm}$. long (denser and shorter in the type); outer glumes $4 \frac{1}{2}-5 \mathrm{~mm}$. long, flowering glume slightly shorter, scabrous on the nerves and with 4 very short teeth; awn attached a little above the middle and shortly exserted ; tuft short; bristle hairy, about $\frac{1}{3}$ as long as the flowering glume.-Deyeuxia densa, Benth.; Agrostis densa, F. v. M.

Mount Lofty Range. Nov.-Apl.

5. C. minor (Benth.), J. M. Black. A slender grass, shorter than the preceding ; leaves filiform; ligule rather long, truncate; panicle spikelike, cylindrical or slightly lobed, $2.4 \mathrm{~cm}$. long; outer glumes broad, about $4 \mathrm{~mm}$. long; flowering glume shorter, broad, with 4 prominent scabrous nerves (the 5th only reaching to the insertion of the awn), 4-toothed at summit, finely tuberculate in lower half; awn inserted near middle of flowering glume; tuft $\frac{1}{3}$ as long as glume; no bristle.-Deyeuxia minor, Benth.

Mount Lofty, Nov.-Jan.

\section{GASTRIDIUM, Beauv.}

(Diminutive of Greek gastêr, abdomen; spikelets swollen at base.)

*1. G. lendigerum (L.), Gaudin. Nitgrass. Glabrous annual; leaves narrow, rough on the edges; ligule lanceolate; spikelets 1 -flowered, arranged in a silvery cylindrical spikelike panicle, $4.10 \mathrm{~cm}$. long, the rhachilla continued in a plumose bristle; outer glumes 2 , keeled, swollen and shining at base, the 1 st $5-6 \mathrm{~mm}$. long, the 2nd shorter ; flowering glume much shorter $\left(1 \frac{1}{4} \mathrm{~mm}\right.$.), pubescent, usually with a short fine awn rising from below the toothed summit; grain ovoid.

Adelaide plains; Mount Lofty and Flinders Ranges; Eyre's Peninsula. Oct.-Dec.Mediterranean region.

\section{DICHELACHNE, Endl.}

(Greek dikhelos, cloven-footed; akhne, glume: the flowering glume is 2-lobed.)

Spikelets 1 -flowered, paniculate, the rhachilla not continued in a bristle ; outer glumes 2 , persistent, membranous, keeled ; flowering glume on a short hairy callus, conspicuously 2-lobed, with a slender awn affixed on the back of the glume and a little below the lobes; anthers glabrous. Perennial grasses resembling Stipa in habit.

Awns long and concealing the spikelets of the broad panicle D. crinita 1.

Awns shorter and less conspicuous; panicle narrower..... D. sciurea 2.

1. D. crinita (L. f.), Hook f. Plume grass. Tall grass, with flat glabrous or pubescent leaves; panicle dense, spikelike but rather broad, 10-20 cm. long. silvery and very hairy owing to the numerous awns ; outer glumes subequal, narrow, hyaline, about $8 \mathrm{~mm}$. long; flowering glume shorter, with a slender dorsal untwisted awn which is $3-5 \mathrm{~cm}$. long.

Throughout the moister districts, as far north as the Flinders Range.

2. D. sciurea (R. Br.), Hook f. Shorter and more slender, about $50 \mathrm{~cm}$. high ; panicle narrower and looser, $8-15 \mathrm{~cm}$. long ; awns $1 \frac{1}{2}-2 \frac{1}{2} \mathrm{~cm}$. long, less numerous, bent and twisted below the knee.

Mount Lofty Range and South-East. 


\section{AMMOPHILA, Host.}

(Greek ammos, sand ; philos, loving.)

* 1. A. arenaria (L.), Link. Marram-grass. Perennial, with creeping rootstock and erect stems; leaves inrolled; ligule bifid; spikelets 1-flowered, in a cylindrical strawcolored panicle, $10-25 \mathrm{~cm}$. long; outer glumes 2, keeled, about $12 \mathrm{~mm}$. long; flowering glume shorter, stiff, 3-toothed at summit, with a basal tuft of hairs and a bristle at base of palea.-A. arundinacea, Host.

Planted along sea-coast to fix drifting sand. Sept.-Dec.-Europe; North America.

\section{PENTAPOGON, R. Br.}

(Greek pente, five ; pōgōn, beard : the flowering glume has 5 awns.)

1. P. quadrifidus (Labill.), Baill. Erect annual; spikelets 1-flowered in a rather dense branched panicle ; outer glumes 2, narrow, 6-12 mm. long, acute ; flowering glume nearly as long, on a short hairy callus ; the central awn $1 \frac{1}{2}-2 \frac{1}{2} \mathrm{~cm}$. long, with 2 much shorter awns on each side.-P. Billardieri, R. Br.

Recorded by Bentham for "St. Vincent's Gulf, F. Mueller ; Barossa Range, Behr," but does not appear to have been re discovered.

\section{LAGURUS, L.}

(Greek lagos, a hare ; oura, a tail : alluding to the shape of the panicle.)

* 1. L. ovatus, L. Hare's-tail grass. Annual ; leaves flat, pubescent, the uppermost sheath swollen; spikelets 1-flowered, in a dense ovoid spikelike silky-white panicle, $2-4 \mathrm{~cm}$. long; outer glumes equal, tapering into a plumose awn ; flowering glume much shorter, with 2 short terminal awns, and 1 long bent dorsal awn.

Sandy soil near sea. Sept.-Dec.-Mediterranean coasts.

Tribe 7. Aveneae. Spikelets 2-many-flowered, paniculate; flowering glumes usually shorter than the outer glumes, bearing a dorsal awn, or rarely a terminal awn or none.

\section{ERIACHNE, R. Br.}

(Greek erion, wool; akhne, glume : the flowering glume, and sometimes the outer glumes are hairy.)

Spikelets with 2 bisexual flowers, paniculate; outer glumes 2, persistent, acute, manynerved ; flowering glume 5-7 nerved, hairy at base and usually on the back, awnless or with an untwisted terminal awn; palea flat, with 2 almost marginal nerves; ligule a ring of hairs. Perennial grasses.

A. Awn about as long as flowering glume ; panicle loose....

A. Awn absent or reduced to a short point; panicle contracted.

B. Outer glumes about $6 \mathrm{~mm}$. long.

Flowering glume not ciliate in upper part ..... E. ovata 2.

Flowering glume ciliate to summit ......... E. mucronata 3.

B. Outer glumes about $4 \mathrm{~mm}$. long; leaves pungent .... E. scleranthoides 4. ' $^{\prime}$

1. E. aristidea, F. v. M. Stems bearded at nodes; leaves flat, bearded at orifice of sheath; panicle loose; outer glumes turning purplish, 8-10 mm. long, with spreading hairs seated on tubercles; flowering glume rather shorter, villous on back, tapering into an awn as long as or shorter than the glume; palea hairy, bifid with 2 long points.

Throughout the Far North. Summer.

2. E. ovata, Nees. Leaves narrow, erect, long, with subulate points ; panicle ovate, rather dense, $3-5 \mathrm{~cm}$. long, the spikelets on short pedicels or almost sessile ; outer glumes purplish, 5-6 mm. long, subacute, 11-13-nerved, glabrous; flowering glume slightly longer, mucronate, strongly 7 -nerved, villous in lower half, but without cilia reaching to the summit; palea shortly bifid and hairy on back.

Far North. Summer.

Var. pallida, Benth. Panicle oblong, looser, 8-14 cm. long; leaves longer ; outer glumes pale or purplish, 11-15-nerved; flowering glume and palea considerably longer than outer glumes (8-9 $\mathrm{mm}$. long), and often recurved.

Far North (near Oodnadatta).

Var. pedicellata. Resembles the preceding, but the spikelets are on capillary pedicels of $5.8 \mathrm{~mm}$. and the flowering glume rather shorter $(6-7 \mathrm{~mm}$.) obtusely mucromate, very villous but not ciliate in the upper part, and exceeding very slightly the outer glumes.

Musgrave Ranges.

E. pallida, F. V. M., and E. obtusa, R. Br. have not been found in South Australia.

3. E. mucronata, R. Br. Stems slender, stiff, ascending from a woolly base, 40-60 cm high ; leaves all short, or the lower ones longer, distant, narrow, stiff, but not pungent, the lower sheaths pubescent ; panicle narrow, few-flowered, 4-6 cm. long ; outer glumes 
about $6 \mathrm{~mm}$. long, glabrous, acute, 13-15-nerved; flowering glume rather longer, shortly mucronate, villous in the lower half, and ciliate with long hairs on the marginal nerves almost to the top; palea almost entire, hairy towards base.

Tarcoola; Ferdinand River, and eastward to New South Wales border. Most of the year.

4. E. scleranthoides, F. v. M. Stems rather short and leaves rigid, the latter subulate

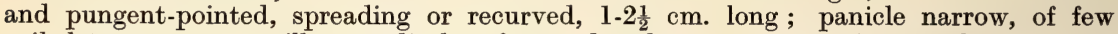
spikelets on erect capillary pedicels, often reduced to a raceme $1 \frac{1}{2}-3 \mathrm{~cm}$. long ; outer glumes 4-5 mm. long, acute, purplish, glabrous, 9-nerved; flowering glume rather longer, mucronate, villous.

Far North and North-West. Spring and summer.

\section{AIRA, L.}

(Greek name for Darnel.)

Spikelets 2-flowered, the rhachilla not continued; outer glumes 2, persistent, membranous, keeled, 1-nerved; flowering glume awned or not . Slender annual grasses.

Outer glumes longer than the awned flowers ......... A. caryophyllea 1.

Outer glumes shorter than the awnless flowers.......... A. minuta 2.

* 1. A. caryophyllea, L. Silvery Hairgrass. Panicle loose, narrowed towards base, with long capillary branches ; outer glumes acute, shining, $2 \mathrm{~mm}$. long ; flowering glumes shorter, with a fine almost basal awn surpassing the outer glumes.

Settled districts. Sept.-Nov.-Europe.

* 2. A. minuta, L. Usually smaller; panicle spreading; outer glumes obtuse, purplish, $1 \frac{1}{2} \mathrm{~mm}$. long, shorter than the truncate awnless flowering glumes.

Settled districts. Aug.-Oct.-Mediterranean region.

\section{DESCHAMPSIA, Beauv.}

(After Dr. J. F. L. Deschamps, a French physician.)

1. D. caespitosa (L.), Beauv. Tall, glabrous perennial; leaves flat, scabrous ; ligule lanceolate; spikelets 2 -flowered, shortly pedicellate, forming a large spreading panicle, the rhachilla prolonged in a hairy bristle or barren flower; outer glumes 2 , membranous, keeled, acute, about $3 \mathrm{~mm}$. long; flowering glumes scarcely exceeding them, truncate and toothed with a straight dorsal awn not longer than the flowering glume; the 2nd flower raised on a short stalk.-Aira caespitosa, $\mathrm{L}$.

South-East.

\section{AVENA L.}

(Latin name for the Oat.)

Spikelets paniculate usually with 2-3-stalked flowers, the terminal flower, where there are more than 2, mostly male or empty; outer glumes 2, membranous, large, persistent; flowering glume smaller, stiff, bifid, with a long bent and twisted dorsal awn; grain pubescent at summit; rhachilla hairy under flowering glumes; grain deeply furrowed, pubescent at summit.

Flowering glume shortly bifid .................. fatua 1.

Flowering glumes ending in 2 long points $\ldots \ldots \ldots \ldots \ldots$ A. barbata 2.

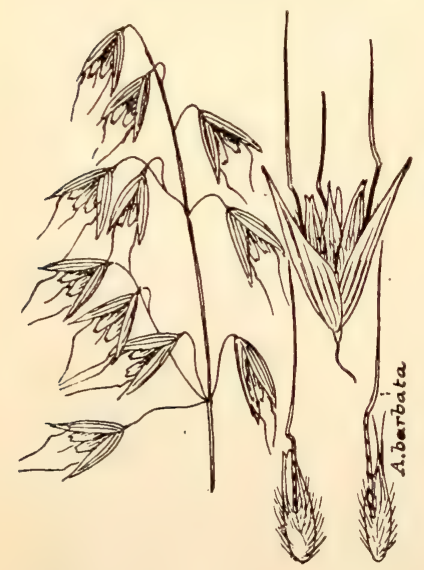

* 1. A. fatua, L. Wild Oat. Annual, with a loose; pyramidal panicle; spikelets 2-3-flowered, often drooping; flowering glume golden-brown, usually covered with long hairs; awn twice as long as the spikelet.

Cultivated and waste ground throughout the State. May-Dec.-Cosmopolitan.

* 2. A. barbata, Brot. Bearded Oat. Differs from the the above in the 1-sided panicle; the outer glumes rather unequal ; flowering glume with long white hairs, not shortly bifid, but terminating in 2 long points or bristles.

Waste places. Sept.-Nov.-Mediterranean region. 
43. HOLCUS, L.

(Latin form of Greek holkos, some species of grass.)

* 1. H. lanatus, L. Yorkshire Fog. Erect softly villous perennial; panicle downy, oval-oblong, light-pink to violet; spikelets 2 -flowered, the lower flower bisexual, the upper male, both stalked; outer glumes $4-5 \mathrm{~mm}$. long, enclosing the flowering glumes, which are much smaller, the upper one with a curved dorsal awn not exceeding the outer glumes.

Moist places. Oct.-Mar.-Europe.

\section{AMPHIBROMUS, Nees.}

(Greek amphi, about ; bromos, oat : near the genus Avena.)

1. A. nervosus (R. Br.), Hook f. Glabrous erect grass; spikelets 3-7-flowered, longer than the outer glumes, on capillary pedicels in a narrow panicle, $10-25 \mathrm{~cm}$. long; outer glumes 2, acuminate, 3-5-nerved, the 1st shorter; flowering glume $5.8 \mathrm{~mm}$. long, stiff, scabrous, with a tuft of hairs at base, 5 nerves reaching the toothed summit and a bent reddish awn attached about the middle of the back; grain deeply turrowed. (Fig. 18.) - A. Neesii, Steud. ; Danthonia nervosa, Hook f.

Mount Lofty and Flinders Ranges; South-East; River Murray.

\section{DANTHONIA, DC.}

(After Danthoine, a French botanist.)

Spikelets several-flowered, paniculate or racemose, with a hairy callus at base ; outer glumes 2, persistent, keeled, acute, several-nerved, as long as or longer than the flowers; flowering glumes smaller, convex on the back, rigid, 7-9-nerved, deeply cut into 2 lateral lobes, with a bent awn rising between them; grain scarcely furrowed. Perennials.

A. Awn equalling or slightly exceeding the lobes of the flowering glume.

Lobes much longer than base .............. D. bipartita 1.

Lobes shorter or scarcely longer than base $\ldots \ldots \ldots \ldots$ D. carphoides 2.

A. Awn much longer than lobes ............. penicillata 3 .

1. D. bipartita, F. v. M. Base almost bulbous and rather woolly; leaves flat, scabrous on edges ; spikelets few, in a narrow panicle, 4-8-flowered; outer glumes 10-15 mm. long; lobes of flowering glume broadly lanceolate, not awned and 3 times as long as the short entire basal portion; the central awn scarcely longer than the lobes.

Oodnadatta to Musgrave Ranges. Spring.

2. D. carphoides, F. v. M. Usually a short grass; leaves inrolled-filiform, glabrous or with short scattered hairs; panicle or raceme dense, ovate, $1 \frac{1}{2}-3 \mathrm{~cm}$. long; spikelets few, 3-6-flowered; outer glumes $6-8 \mathrm{~mm}$. long, broad and green when flowering, with broad white margins; lobes of flowering glume shorter or slightly longer than base; awn equalling or somewhat exceeding the lobes.

Adelaide plains northward to Hallett; Mount Lofty Range ; South-East.

3. D. penicillata (Labill.), F. v. M. Wallaby Grass. Stems 10-50 cm. high; leaves inrolled-filiform or setaceous; panicle ovate-oblong, dense or rather loose, $3-10 \mathrm{~cm}$. long ; spikelets erect, 15-25 mm. long with the awns, 6-8-flowered; outer glumes 10-18 mm. long, exceeding the flowers without the awns; lateral lobes of the flowering glume tapering in to the fine awns and much longer than the basal entire part, which is more or less covered by long white hairs, often arranged in tufts; central awn exceeding the lobes.-D. racemosa, D. semiannularis, R. Br.

All over the State except the Far North. Spring and summer.

Var. setacea. Resembles D. carphoides, having the same short dense panicle, but the lateral lobes are awned and twice as long as the base, and the awn is longer than they.D. setacea, R. Br.

\section{PENTASCHISTIS, Stapf.}

(Greek pente, five; skhistos, cut : the flowering glume has about 5 divisions at the summit.)

* 1. P. Thunbergii (Kunth), Stapf. Perennial about $30 \mathrm{~cm}$. high with narrow leaves bearded at orifice of sheath; spikelets 2 -flowered, numerous, in a golden-brown rather dense ovate panicle, $2-5 \mathrm{~cm}$. long; outer glumes 2 , membranous, 1 -nerved, 4-5 mm. long, enclosing the small flowers, of which only the awns protrude; flowering glume hairy, with 2 lobes and a bent and twisted central awn rising between the lobes, which have each a short, slender awn or bristle at the inner side of the summit and 2 teeth at the outer side.

Golden Grove, near Adelaide. Nov.-Dec.- South Africa.

Tribe 8. Festuceae. Spikelets 2 -several-flowered, pedicellate, paniculate; the flowering parts of the spikelet usually longer than the outer glumes; flowering glumes awnless or with a terminal or almost terminal straight awn. 
47. PAPPOPHORUM, Schreb.

(Greek for "pappus-bearing": alluding to the conspicuous feathery pappus.)

Spikelets paniculate, with 1 bisexual flower and 1 or more male or rudimentary flowers above it ; outer glumes 2 , subequal, membranous, many-nerved, shorter than the flowers ; flowering glume broad, 9-nerved and with 9 plumose awns. Erect perennials.

Outer glumes 5-9-nerved .................... P. nigricans 1 .

Outer glumes 9-21-nerved ...................... $P$. avenaceum 2.

1. P. nigricans,, R. Br. Black Heads. Leaves subulate, rather stiff; panicle oblongcylindrical, dense, $1-10 \mathrm{~cm}$. long, light or lead-colored; outer glumes 3-5 mm. long, 5-9nerved; awns spreading and longer than the short entire basal part of the flowering glume.

Throughout the State. Aug.-Jan.

2. P. avenaceum, Lindl. Resembles the preceding, but the panicles looser, the outer glumes 5-7 mm. long, 9-21-nerved.

Far North. July-Jan.

48. TRIRAPHIS, R. Br.

(Greek treis, three; rhaphis, a needle : the flowering glumes are 3-awned.)

Spikelets several-flowered, paniculate, the terminal glume usually male or empty; outer glumes 2, subequal, acute, shorter than the flowers; flowering glume narrow, 3-nerved, the nerves leading to 3 narrow lobes which taper into straight slender awns; ligule of hairs. Perennials.

Panicle dense ; leaves soft $\ldots \ldots \ldots \ldots \ldots \ldots \ldots \ldots \ldots$ T. mollis 1.

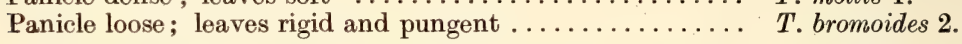

1. T. mollis, R. Br. Erect, glabrous ; leaves narrow, flat ; panicle dense, soft, narrow, often purplish, 4-16 cm. long; outer glumes membranous, 1-nerved, 3-6 $\mathrm{mm}$. long, much shorter than the flowers; flowering glume ciliate on the marginal nerves, the central awn rising between 2 narrow teeth and the other 2 awns shorter and lateral.

Far North; River Murray. Aug.-Feb.

2. T. bromoides, F. v. M. A glabrous "porcupine grass"; leaves subulate, rigid, pungent, $8-15 \mathrm{~cm}$. long; panicle loose but narrow, $10-20 \mathrm{~cm}$. long, on a long stem; outer glumes $13-16 \mathrm{~mm}$. long; awns of flowering glume 10-12 mm. long, dilated towards base.

Everard Range.

\section{ELYTROPHORUS, Beauv.}

(Greek elytron, a sheath ; phoros, bearing : alluding to the scarious glumes.)

1. E. articulatus, Beauv. Glabrous annual, with flat leaves; spikelets small, fewflowered, sessile in globular clusters forming a rather long, often interrupted spike; outer glumes 2, narrow, pointed; flowering glume 3-nerved, with 3 minute awns; palea folded.

Recorded by Bentham for "South Australia. Murray River, F. Mueller; Charlotte Waters, Central Australia, Giles," but has not been found since.

\section{TRIODIA, R. Br.}

(Greek treis, three; odous, a tooth : the flowering glume is divided into 3 obtuse or acute teeth.)

Spikelets several-flowered, compressed laterally, paniculate; outer glumes 2, stiff, keeled, shorter than the flowers; flowering glume stiff, rounded on back, the nerves arranged in 3 sets of 3 nerves each, with 3 lobes or with 2 lobes and a central mucro; ligule a ring of hairs. Leaves ending in needle-like points (in all our species); hence these plants are called "porcupine grasses," or (wrongly) "spinifex." Perennials.

A. Flowering glume divided to the middle into 3 lobes .... T. pungens 1 .

A. Flowering glume with 2 lateral lobes and a central mucro.

B. Leaves and outer glumes glabrous.

Flowering glume with a mucro shorter than the obtuse lobes ......................... T irritans 2.

Flowering glume with a mucro longer than the acute

lobes ................................. T. aristata 3 .

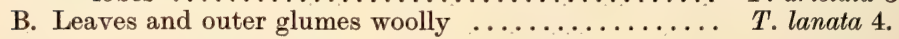

1. T. pungens, R. Br. A tussock grass, somewhat glutinous; leaves subulate, rigid, spreading, pungent-pointed, the sheaths sometimes woolly; panicle narrow, $8-15 \mathrm{~cm}$. long; spikelets on slender pedicels, $8-12 \mathrm{~mm}$. long; outer glumes 6-8 mm. long, glabrous, 5-7-nerved; flowering glume purplish, cut halfway into 3 broad obtuse 3-nerved lobes, silky-villous towards base.

Northern part of Flinders Range and Far North from Cooper's Creek to West Australian boundary. June-Dec. 
2. T. irritans, R. Br. Resembles the preceding; leaves pungent, glabrous; panicle narrow, 12-30 cm. long; spikelets $10-20 \mathrm{~mm}$. long, 4-12-flowered; outer glumes $5-11 \mathrm{~mm}$. long, glabrous, acute, sub-5-nerved, much shorter than the flowers; the midnerve of the flowering glume ending in a mucro shorter than the 2 obtuse lateral lobes, the glume more or less silky-villous in the lower half, straw-colored or purplish.

Adelaide northwards to Flinders Range; Murray lands ; Far West.

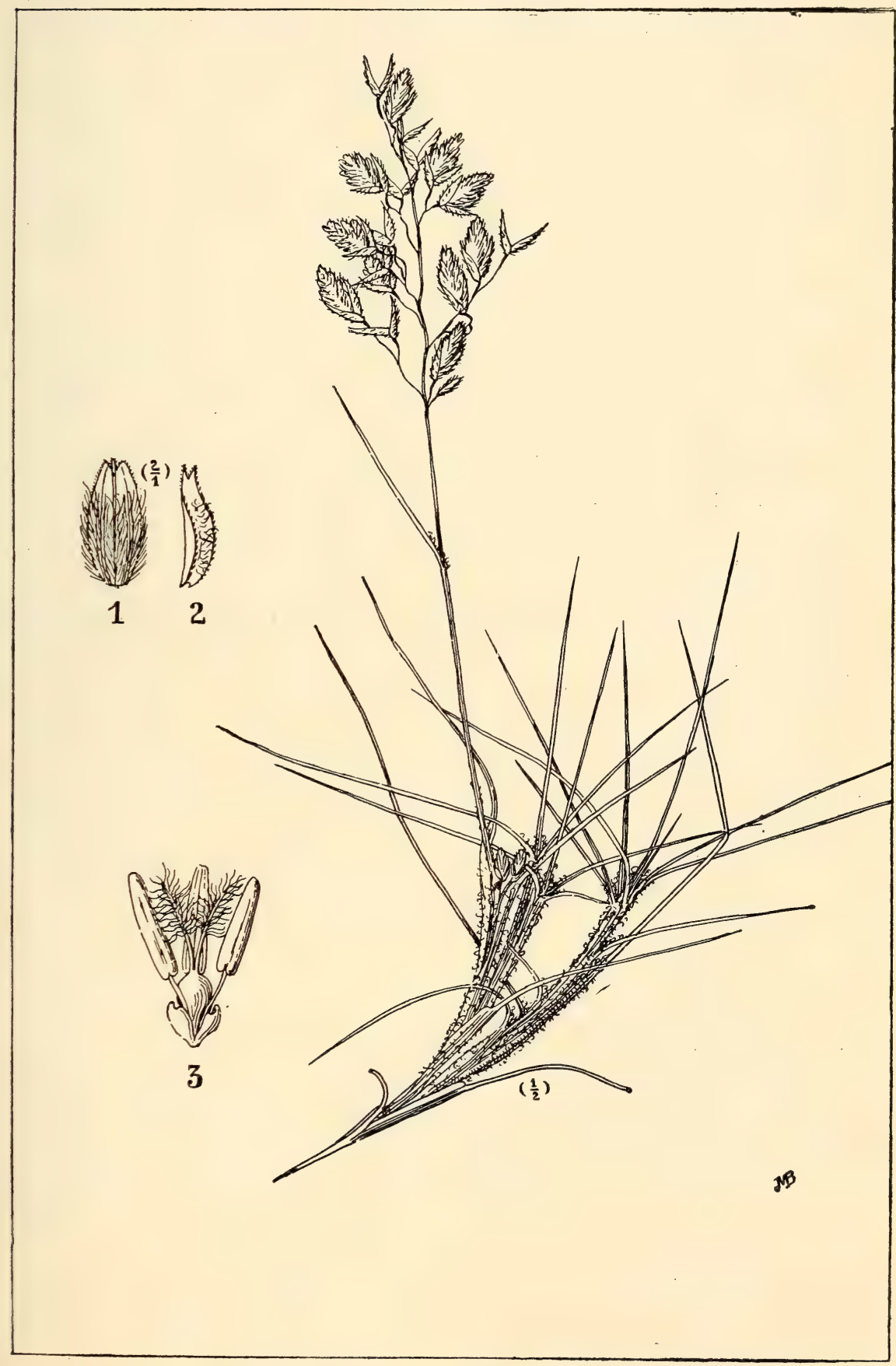

Plate 3.-Triodia lanata, J. M. Black. 
3. T. aristata, J. M. Black. Like the preceding, but the panicles are shorter and strawcolored; outer glumes 12-14 $\mathrm{mm}$. long, about as long as the flowers and acuminate in a short mucro ; flowering glume with 2 acute lobes and a mucro or short awn exceeding them (2-3 mm. long). Resembles Festuca littoralis.

Everard Range.

4. T. lanata, J. M. Black. Leaves slender, subulate, pungent, woolly towards the base and on the sheaths; panicle narrower, but rather loose ; spikelets ovate, 5-7-flowered, straw=colored, densely woolly or silky-villous; outer glumes $10 \mathrm{~mm}$. long, 3-nerved, silky; flowering glume silky nearly to the summit, the mucro about as long as the 2 lateral lobes or teeth.

Minnipa, E. P.

Plate 3.-1, flowering glume; 2, palea; 3, pistil stamens and lodicules.

\section{DIPLACHNE, Beauv.}

(Greek diploos, double; akhne, a glume : the flowering glume is 2-lobed.)

Spikelets several-flowered, sessile or almost so, in simple or paniculate spikes; outer glumes 2, keeled; flowering glume rounded or flat on back, closely imbricate, scarious, ending in 2 short lobes with a short point or awn between them; palea broad, flat; ligule membranous, jagged.

Spike slender, simple $\ldots \ldots \ldots \ldots \ldots \ldots \ldots \ldots \ldots \ldots$ D. loliiformis 1.

Spikes arranged in a simple panicle ............. D. fusca 2.

1. D. loliiformis, F. v. M. Small erect annual ; leaves very narrow, the sheaths broad and whitish; spike $2-8 \mathrm{~cm}$. long, l-sided; spikelets narrow, almost cylindrical, erect, appressed, $5-10 \mathrm{~mm}$. long; flowering glume $3 \mathrm{~mm}$. long, hairy at base, the midnerve prolonged in a short awn exceeding the lateral lobes ; grain fusiform.'

Far North, in wet depressions. Most of the year.

2. D. fusca (L.), Beauv. Rather tall perennial; leaves long, with loose sheaths; panicle narrow, 10-40 cm. long, with erect branches; spikelets compressed dorsally, almost sessile, whitish or lead-colored, 6-14-flowered, 10-15 mm. long; midnerve of the flowering glume produced into a point shorter or a little longer than the lateral lobes, the nerves silky-ciliate in the lower half ; palea also ciliate with long hairs on the nerves; seed obovate, pericarp loose.

Far North; Murray lands.

Var. Muelleri. Spikelets almost white and apparently broader, owing to the flowering glumes being more flattened dorsally; ciliation dense at base of flowering glume.- $D$. Muelleri, Benth.

Flinders Range and Far North.

\section{PHRAGMITES, Trin}

(Greek phragmites, growing in hedges: plants crowded together in a row along the water's edge.)

1. Ph. communis, Trin. Common Reed. Stout perennial, 1-3 m. high, with long leaves, 1-3 cm. broad, covering the stem; spikelets 3-7-flowered, in a large, branching, brownish panicle, $15-30 \mathrm{~cm}$. long, silvery from the long silky hairs which rise from the rhachilla and envelop the flowers; outer glumes 2, membranous, keeled, acute, unequal, shorter than the flowers; flowering glumes membranous, acuminate with long soft points.Arundo Phragmites, L.

Banks of the Torrens; Reedbeds; beside creeks throughout the cooler districts; often growing along with Typha angustifolia.

\section{LAMARCKIA, Moench.}

(After the French naturalist, J. B. de Lamarck, 1744-1829.)

* 1. L. aurea (L.), Moench. Small glabrous annual; spikelets of 2 kinds intermixed on the panicle-branches; the fertile ones with 1 bisexual flower, of which the flowering glume is 2 -toothed and awned, just below the notch, and 1 stalked empty glume above it, also with a slender awn; the sterile spikelets consisting of 2 lanceolate outer glumes (like those of the fertile spikelet), and 6-9 obovate imbricate empty glumes; panicle unilateral, spikelike, ovate-oblong, golden.-Cynosurus aureus, L.

Murray district; Flinders Range. Oct.-Mar.-Mediterranean region.

\section{CYNOSURUS, L.}

(Greek kynos, of a dog ; oura, tail : shape of the panicle.)

* 1. C. echinatus, L. Rough Dog's-tail. Erect annual; spikelets of 2 kinds as in Lamarckia, but the f rtile ones with 2-3 bisexual awned flowers, surrounded by the sterile spikelets, which consist of numerous rigid lanceolate awned glumes, arranged in 2 opposite rows; panicle ovate or oblong, $1 \frac{1}{2}-3 \mathrm{~cm}$ long, dense, very bristly; flowering glume 5-nerved.

Roadsides, Mount Lofty and Stirling. Oct.-Dec.-Mediterranean region. 
55. KOELERIA, Pers.

(After G. L. Köler, a German botanist.)

Spikelets compressed laterally, 2-6-flowered, in a narrow panicle; outer glumes 2, membranous; flowering glumes 3-5-nerved, sometimes shortly awned in the notch, the upper ones gradually smaller and stalked.

Outer glumes slightly unequal, shorter than Howers $\ldots \ldots K$. phleoides 1.

Outer glumes very unequal, longer than flowers ....... K. Michelii 2.

* 1. K. phleoides, Pers. Ascending annual, with somewhat hairy leaves ; panicle dense, spikelike, 1-12 cm. long, when large slightly lobed, cylindrical or oblong, silvery ; spikelets 3-4 mm. long, 4-6-flowered; outer glumes sprinkled with some long hairs, shorter than the flowers ; flowering glume 5-nerved, with a short awn rising from the notch at summit.

Common throughout the State. Sept.-Nov.-Mediterranean region.

* 2. K. Michelii, Cosson. Annual, with pubescent leaves; panicle narrow but looser than in the preceding species, $1-9 \mathrm{~cm}$. long, light-colored; the lowest glume very small, the second much larger and equalling or exceeding the flowers ; flowering glume narrowcylindrical, with an awn in the notch half as long as the glume.

Southern districts; Murray lands. Sept.-Nov.-Mediterranean region.

\section{TRISETUM, Pers.}

(Latin tres, three ; seta, bristle : the flowering glume ends in 2 teeth and bears a dorsal awn.)

*1. T. pumilum, Kunth. Annual, usually small, with ascending stems; leaf-sheaths pucescent ; spikelets 3-4-flowered, $4 \mathrm{~mm}$. long, in a spikelike but rather loose panicle of $\mathbf{1 - 5} \mathrm{cm}$. ; rhachilla with tufts of hairs half as long as the flowering glumes and ending in a hairy bristle; outer glumes subequal, densely pubescent, shorter than the flowers; flowering glume 5-nerved, 2-toothed, with a slender awn rising just below or in the notch formed by the teeth and about $\frac{1}{2}$ as long as the glume.

Established in the North, Far North, and North-West. Aug.-Oct.-Bouth Africa.

\section{BRIZA, L.}

(Greek briza, name of some form of Rye.)

Spikelets compressed laterally, with several spreading, closely imbricate flowers hanging in a loose panicle ; outer glumes 2, almost equal, boatshaped, 7-9-nerved ; flowering glumes membranous, concave, obtuse ; palea much smaller; ligule long, scarious.

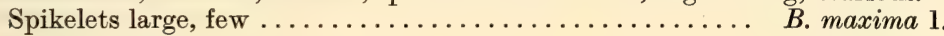

Spikelets small, numerous ................. minor 2 .

* 1. B. maxima, L. Large Quaking-grass. Glabrous annual ; panicle 1-sided, simple ; spikelets few, 10-20 mm. long, drooping on filiform pedicels, 9-17-flowered, golden.

Mount Lofty Range and cool districts. Sept.-Dec.-Mediterranean region.

* 2. B. minor, L. Lesser Quaking-grass. Glabrous annual; panicle compound ; spikelets many (except in starved specimens), pale-green, 3-5 $\mathrm{mm}$. long.

Same localities.-Europe.

\section{DACTYLIS, L.}

(Greek daktylos, a finger : shape of the panicle.)

*1. D. glomerata, L. Cock's-foot-grass. Tall perennial; leaves flat, long; spikelets 3-5-flowered, in dense 1-sided clusters at the end of the branches of a long panicle, which is narrow except when in flower; outer glumes 2, subequal, shorter than the flowers ; flowering glume 5-nerved, with a ciliate keel, 2 teeth and a short terminal point or awn.

Mount Lofty Range; South-East. Nov.-Dec.-Europe; Asia.

\section{ERAGROSTIS, Beauv.}

(Greek erōs, love ; agrōstis, grass : alluding to the elegance of the spikelets.)

Spikelets of several or many flowers, paniculate, the rhachilla fragile or persistant; outer glumes 2, keeled, much shorter than the flowers; flowering glumes unawned, 3 nerved; palea shorter, prominently 2-nerved, usually persistant after the flowering glume' and grain have fallen; grain glabrous, not furrowed, with a punctiform hilum; ligule reduced to a ring of hairs. Love-grass.

A. Spikelets slightly flattened, without a longitudinal furrow; lateral nerves faint or marginal.

B. Spikelets $1-4 \mathrm{~mm}$. long $\ldots \ldots \ldots \ldots \ldots \ldots \ldots \ldots$

B. Spikelets $3-10 \mathrm{~mm}$. long.

Grain oblong $\ldots \ldots \ldots \ldots \ldots \ldots \ldots \ldots \ldots$

Grain ovoid.

E. tenella 1 .

Leaves glabrous $\ldots \ldots \ldots \ldots \ldots \ldots \ldots \ldots$

E. leptocarpa 2.

Leaves hairy $\ldots \ldots \ldots \ldots \ldots \ldots \ldots \ldots \ldots \ldots$

E. pilosa 3 .

E. trichophylla 4. 
A. Spikelets very flat when mature, with a longitudinal furrow between the 2 rows of glumes.

C Base of stems glabrous.

D. Spikelets sessile or almost so, clustered.

E. Palea almost as long as flowering glume.

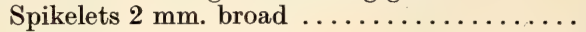

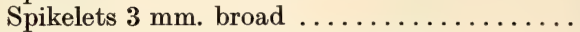

E. Palea not $\frac{1}{2}$ as long as flowering glume $\ldots \ldots \ldots$. D. Spikelets shortly pedicellate in panicles.

F. Leaves without glandular teeth............

F. Leaves with glandular teeth.

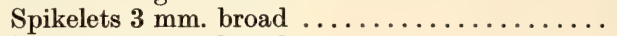

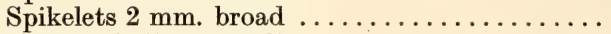

C. Base of stems bulbous-woolly.

Spikelets $3 \mathrm{~mm}$. broad $\ldots \ldots \ldots \ldots \ldots \ldots \ldots \ldots$

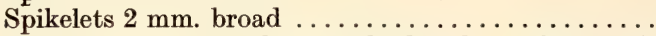

A. Spikelets very narrow, almost cylindrical, not furrowed. Spikelets pedicillate, distant $\ldots \ldots \ldots \ldots \ldots \ldots \ldots$ Spikelets sessile, clustered . . . . . . . . . . . .

E. diandra 5.
E. concinna 6.
E. speciosa 7.

E. Brownii 8.

E. major 9.

E. minor 10.

E. eriopoda 11 . E. setifolia 12 .

E. falcata 13.

E. Dielsii 14.

1. E. tenella (L.), Roem. et Schult. Erect annual $20-50 \mathrm{~cm}$. high ; leaves flat; panicle occupying the greater part of the plant, with long or short spreading branches ; spikelets 4-8-flowered, $1.4 \mathrm{~mm}$. long, $1 \mathrm{~mm}$. broad, shortly pedicellate, often purplish ; flowering glumes obtuse, about $1 \mathrm{~mm}$. long, loosely imbricate, the nerves prominent; palea glabrous or ciliate on the nerves; rhachilla breaking up from the top downwards ; grain ovateoblong, $\frac{1}{2} \mathrm{~mm}$. long.

Far North. Spring. A very beautiful delicate grass.

2. E. leptocarpa, Benth. Resembles the preceding, but the spikelets are pale or leadcolored, narrow-linear 3-6 mm. long, $\frac{3}{4} \mathrm{~mm}$. broad, 4-10 flowered, light or purplish; flowering glume obtuse, often notched, $2 \mathrm{~mm}$. long ; rhachilla not disarticulating ; palea ciliate on the nerves or almost glabrous, usually deciduous; grain oblong linear, $1 \frac{1}{4} \mathbf{m m}$. long.

Far North and North-West ; Fowler's Bay. Most of the year.

3. E. pilosa (L.), Beauv. Glabrous annual, often reaching $60 \mathrm{~cm}$.; leaves narrow ; panicle large and loose, with long spreading branches; spikelets linear, 6-18-flowered, 3-10 mm. long, $1 \mathrm{~mm}$. broad, usually lead-colored, on pedicels of $2-4 \mathrm{~mm}$. ; rhachilla not disarticulating; flowering glumes closely imbricate, subacute, $1 \frac{1}{2} \mathrm{~mm}$. long, lateral nerves faint : paleas ciliate, persistant; pedicels only slightly diverging, so that the spikelets lie almost parallel to the panicle-branches; grain ovoid, $\frac{3}{4} \mathrm{~mm}$. long.

Murray lands ; Far North. Summer.

4. E. trichophylla, Benth. Stems slender; lower leafblades villous; panicle rather loose, about $15 \mathrm{~cm}$. long; spikelets linear, 8-12-flowered, 4-6mm long, $1 \mathrm{~mm}$. broad, light-colored or purplish; glumes obtuse, $1 \frac{3}{4} \mathrm{~mm}$. long, the lateral nerves conspicuous ; grain obovoid, $\frac{1}{2} \mathrm{~mm}$. long.

From Fowler's Bay northward. Summer.

5. E. diandra, Steud. Leaves narrow, glabrous; panicle an interrupted spike of $5-15$ cm. : spikelets lanceolate, 4-7 mm. long, $2 \mathrm{~mm}$. broad, 6-16-flowered, sessile in dense sessile clusters, forming short distant branches towards the base of the panicle ; flowering glumes white or purplish, with conspicuous green lateral nerves; palea nearly as long; stamens 2, small, purple; grain ovoid, $\frac{1}{2}-\frac{3}{4} \mathrm{~mm}$. long; rhachilla not articulate.

Tanunda ; Bordertown; Oodnadatta.

6. E. concinna, Steud. Rather short grass, with flattish leaves, hairy at orifice of sheath ; panicle contracted, 4-10 cm. long ; spikelets lanceolate, clustered, sessile, 8-16 $\mathrm{mm}$. long, $3-4 \mathrm{~mm}$. broad, very flat, 10-34-flowered, often purplish; rhachilla finally disarticulating; flowering glumes $3 \mathrm{~mm}$. long, with prominent nerves; palea $\frac{3}{4}$ as long as the glume with long cilia on the nerves; grain ovoid, $\frac{3}{4} \mathrm{~mm}$. long.

Country north of Lake Eyre.

7. E. speciosa, Steud. Leaves subulate, glabrous; panicle narrow, sometimes $25 \mathrm{~cm}$. long, the lower branches erect and distant; spikelets finally linear, lead-colored, erect, flat, 10-40-flowered, 6-12 mm. long, under $2 \mathrm{~mm}$. broad, sessile or almost so ; palea ciliolate, not $\frac{1}{2}$ as long as flowering glume; grain ovoid, scarcely $\frac{1}{2} \mathrm{~mm}$. long.

\section{Far North.}

8. E. Brownii, Nees. Leaves narrow, sometimes bearded behind the ligule; panicle $3.15 \mathrm{~cm}$. long, narrow or loose and spreading; spikelets $5-9 \mathrm{~mm}$. long, $2 \mathrm{~mm}$. broad, lanceolate, 6-18-flowered, shortly pedicellate, distant or clustered (in the latter case approaching $\boldsymbol{E}$. diandra); flowering glumes lead-colored, with conspicuous lateral nerves ; palea nearly as long; stamens $2-3$; grain ovoid, almost globular, $\frac{1}{2} \mathrm{~mm}$. long ; rhachilla tardily articulate.

Mount Lofty Range; South-East. 
* 9. E. major, Host. Annual ; leaves glabrous, except for long hairs at orifice of sheath, the blades with small tuberculate teeth along the edges; panicle compact, with short spreading-erect branches ; spikelets becoming lead-colored, 5-15 mm. long, $3 \mathrm{~mm}$. broad; 10-26-flowered, shortly pedicellate; flowering glume obtuse, almost notched, with very prominent nerves ; palea broad, nearly as long; grain ovoid, $\frac{3}{4} \mathrm{~mm}$. long ; rhachilla not disarticulating.

Murray district; northern areas. Summer.-Mediterranean region.

* 10. E. minor, Host. Differs from the preceding by the narrower spikelets $(2 \mathrm{~mm}$. broad), less crowded on the panicle-branches. The tufts of long hairs at the orifice of the leaf sheath, outside the ligule, and the tubercles on the blade, serve to distinguish it from panicled forms of $E$. Brownii.

Flinders Range and Far North. Spring and Summer.-Mediterranean region.

11. E. eriopoda, Benth. Perennial ; stems slender, rising from a swollen, densely woolly base ; leaves setaceous ; panicle narrow and spikelike, or broad with divaricate branches ; spikelets spreading, shortly pedicellate, $5-15 \mathrm{~mm}$. long, $3 \mathrm{~mm}$. broad, 10-40-flowered, flat, glabrous, obtuse; palea broad, nearly as long as the glume, ciliate; grain ovoid.

North of Renmark; Far North and West. Spring and summer.

Var. laniflora. Flowering glumes woolly towards the base with long marginal hairs; palea ciliate on nerves, the hairs longer towards the base.-E. laniflora, Benth. Same localities.

12. E. setifolia, Nees. Perennial, with a swollen, slightly woolly base ; leaves setaceous, or rarely flat and tapering; panicle narrow, with short branches; spikelets numerous, shortly pedicellate, 8-20 mm. long, $2 \mathrm{~mm}$. broad, 12-60-flowered, violet or straw-colored; palea narrow, almost glabrous ; grain ovoid-oblong but small.-E. chaetophylla, Steud.

Throughout the Far North, including the Flinders Range.

13. E. falcata, Gaudich. Slender perennial with setaceous leaves and a spreading panicle of $5.10 \mathrm{~cm}$. ; spikelets few, shortly pedicellate, purple or brown, linear and almost cylindrical (1 mm. broad), straight or somewhat falcate, 10-30-flowered, 5-15 mm. long; flowering glumes obtuse, closely appressed, but rather distant from each other, the lateral nerves faint.-E. lacunaria, F. v. M.

River Murray; Far North and West.

14. E. Dielsii, Pilger. Near the preceding, but the spikelets are sessile or almost so, not so slender ( $1 \frac{1}{2} \mathrm{~mm}$. broad), more frequently curved, crowded, 5-25 mm. long, 10-50flowered; base of plant somewhat swollen.-E. falcata, Benth. non Gaudich.

River Murray; Far North and West.

\section{DISTICHLIS, Rafin}

(Greek distikhos, in 2 rows : position of the leaves.)

1. D. spicata (L.), Greene. Low stiff grass, with creeping stems and almost pungent spreading distichous leaves; spikelets flat, dioecious, 8-12-flowered 10-15 mm. long, in a short raceme; glumes many-nerved, keeled, acute.-D. maritima, Rafin.

Usually in sand on the sea-coast, and also near salt lakes in northern districts. Summer.

\section{SCHISMUS, Beauv.}

(Greek skhisma, division : the flowering glume is split at the top.)

*1. S. calycinus (L ), Coss. et Dur. Small annual ; leaves inrolled-setaceous, glabrous, with long hairs at orifice of sheath ; panicle narrow ; spikelets 6-8-flowered ; outer glumes subequal, 5-nerved, as long as or rather shorter than the flowers; flowering glume broad, 9-nerved, pubescent, bifid and usually mucronate in the notch.-S. marginatus, Beauv.

Country between Terowie and Cockburn. Aug.-Nov.-Mediterranean region; South Africa.

\section{POA, L.}

(Greek poê, grass.)

Spikelets compressed laterally, several-flowered, paniculate; rhachilla articulate : outer glumes 2, 1-3-nerved, shorter than the flowers, persistent; flowering glumes 5-9. nerved, keeled, awnless, often woolly on the back; grain glabrous, with a punctiform hilum, usually free from the palea.

A. Perennials.

B. Panicle long and loose.

C. Spikelets ovate-lanceolate.

Uppermost leafblade as long as sheath ........ P. caespitosa 1 .

Uppermost leafblade much shorter than sheath .. P. pratensis 2.

C. Spikelets broad-lanceolate, quivering .......... Prummondiana 3.

B. Panicle short, contracted.

Base bulbous ................... Pulbosa 4 .

Base not bulbous .................. P. caespitosa, var.

A. Annuals.

Flowering glumes 5 -nerved $\ldots \ldots \ldots \ldots \ldots \ldots \ldots \ldots$. annua 5 .

Flowering glumes $7-9$-nerved $\ldots \ldots \ldots \ldots \ldots \ldots \ldots \ldots$. . lepida 6 . 
1. P. caespitosa, Forst. Rather tall, variable perennial, with long setaceous, rarely flat leaves; ligule very short; panicle pyramidal, often purple, the long lower branches naked towards base and spreading in flower; spikelets rather lanceolate than ovate, 4-8-flowered ; flowering glume 5-nerved, more or less ciliate or woolly on the nerves; grain oblong, sometimes subadherent to palea.

Common in moist districts. Oct.-Dec.

Var. tenera, Benth. A small form, with weak filiform leaves, and the panicle usually reduced to a few small spikelets.-South-East.

Var. Billardieri, Hook. f. A maritime form with shorter, contracted panicles, often straw-colored, the lower branches short.-P. Billardieri, Steud.-Sea-coasts of Kangaroo Island and South-East.

Var. plebeia, Benth. Tall and leafy ; leaves flat with a long obtuse ligule ; flowering glumes obtuse or notched, woolly-ciliate towards base; grain ovoid.-P. plebeia. R. Br. Should probably be considered a distinct species-Morgan; near Lake Frome; Fowler's Bay.

* 2. P. pratensis, L. Perennial with creeping rootstock, resembling the preceding, but the panicle shorter $(4-8 \mathrm{~cm}$. long), the spikelets broader ; $3-5$-flowered, and the flowering glumes more woolly; leaves narrow, channelled, the blade of the uppermost one much shorter than the sheath; grain always free.

Adelaide plains; Mount Lofty Range ; South-East. Oct.-Dec.-Almost cosmopolitan.

3. P. Drummondiana, Nees (1843). A handsome perennial, with flat leaves, quivering spikelets like those of Briza minor on capillary pedicels, forming a loose panicle, $5-15 \mathrm{~cm}$. long; spikelets 4-5 mm. long, 6-8-flowered, broadly ovate; flowering glumes obtuse, spreading, 5-nerved, ciliate in the lower part, especially on the 2 marginal nerves; at the base of the stem are 2 or 3 globular nodules. $-P$. nodosa, Nees (1846-47).

Scrub near Roseworthy; Gladstone; along coast westward of Streaky Bay. Sept.-Dec.

* 4. P. bulbosa, L. Stems slender, swollen into a bulb at base; leaves very narrow ; panicle contracted, $1.4 \mathrm{~cm}$. long; spikelets ovate, 4-6-flowered; flowering glumes faintly 5-nerved, with long woolly hairs on the median and marginal nerves; flowers often transformed into buds (viviparous form).

Near Adelaide; Eyre's Peninsula; South-East. Oct.-Dec.-Europe.

* 5. P. annua, L. Annual Meadow-yrass. Small weak annual, with flat or channelled leaves; panicle with spreading branches, the lowest solitary or 2-3 together; spikelets 3-5-flowered, $2-3 \mathrm{~mm}$. long; flowering glume 5-nerved, silky-ciliate towards base.

Settled districts; a weed in gardens. Spring and summer.-Cosmopolitan.

6. P. lepida, F. v. M. Annual, with leaves flat or channelled and a long ligule; panicle narrow, 3-8 cm. long; spikelets 5-9-flowered, subsessile; flowering glumes 3-4 mm. long, 7-9-nerved, silky-ciliate in lower half.

From the Murray westward to Fowler's Bay, but not common. Aug.-Nov.

63. GLYCERIA, R. Br.

(Greek glykeros, sweet : alluding to the herbage and seeds of G. fluitans.)

Differs from Poa in the flowering glumes rounded on the back, the lateral nerves straight and not converging on the midnerve, the stigmatic hairs branched, and the 2 lodicules sometimes united into 1 . Perennials.

Stems tall, rigid, branched .................... ramigera 1 .

Stems not rigid or branched.

Flowering glumes hairy near base.............. F. Fordeana 2.

Flowering glumes glabrous.

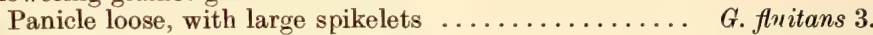

Panicle dense, with short spikelets ........... G. stricta 4.

1. G. ramigera, F. v. M. Cane-grass. Stems stout, rigid, to $3 \mathrm{~m}$. high, the upper branches clustered; stem-leaves few and short; panicle spreading, 10-20 cm. long; spikelets linear, 6-12-flowered; flowering glumes hyaline, obtuse, with 3 short nerves; palea readily splitting into 2 parts; lodicules distinct; grain ovoid, loose within the pericarp.-Poa ramigera, F. v. M.

Near River Murray; Far North. Sept.-Jan.

2. G. Fordeana, F. v. M. Under $1 \mathrm{~m}$. high; leaves flat, scabrous; panicle loose, 10-20 cm. long; spikelets 8-10 $\mathrm{mm}$. long, 8-12-flowered ; flowering glumes obtuse, 5-7nerved, with a tuft of white hairs near the base and pubescent in the lower part.

Recorded from the River Murray and the Wimmera district in Victoria, so that it probably occurs in this State.

3. G. fluitans (L.), R. Br. Manna Grass. Rather stout aquatic grass, with creeping stems; leaves flat; panicle long, loose, unilateral, narrow, the slender branches bearing 1-3 linear spikelets, 15-30 mm. long, 6-14-flowered; flowering glume stiff, 7-nerved; lodicules united; grain ovoid.

Mount Lofty Range; Sonth-East. Nov.-Jan.-Cosmopolitan. 
4. G. stricta, Hook. f. Leaves long, setaceous, erect, with broad sheaths clasping the base of the narrow panicle, which is $5-15 \mathrm{~cm}$. long; spikelets linear, 6-12-flowered, 6-10 $\mathrm{mm}$. long; flowering glumes obtuse, 5-nerved, glabrous; lodicules not united : grain oblong.-Poa syrtica, F. v. M.

Beside fresh or brackish water in all parts of the State. Aug.-Dec

64. SCLEROCHLOA, Beauv.

(Greek sklèros, hard ; kh!oē, grass.)

* 1. S. dura (L.), Beauv. Small, stiff, glabrous annual; stems covered by the broad leafsheaths up to the short unilateral spikelike panicle, which is surpassed by the flat leafblades; spikelets 3-5-flowered; outer glumes unequal, the 2nd longer, 7-nerved ; flowering glumes truncate, keeled, 5-nerved; grain oblong, tapering into a bifid beak.

Near Spalding. Oct.-Dec.-Mediterranean region.

65. FESTUCA, L.

(Latin name of a weed which grew among barley.)

Spikelets several-flowered, paniculate; outer glumes narrow, keeled, the 1st usually 1-nerved, the 2nd 3-nerved; flowering glumes rounded on back, at least in the lower part, the upper part often keeled, 5-nerved, acute, or tapering into a short straight awn, terminal or nearly so ; grain furrowed on the inner face, adherent to the palea.

A. Perennials ; awn short or absent ; outer glumes subequal.

B. Leaves cylindrical.

Leaves rigid, as long as stems $\ldots \ldots \ldots \ldots \ldots \ldots$. littoralis 1.

Leaves soft, much shorter than stems ......... F. duriuscula 2.

B. Leaves flat; stem and panicle long........... F. elatior 3.

A. Annuals.

C. Spikelets spreading at summit; outer glumes very unequal; awn rather long.

Panicle long, arched; 1st glume minute ........ F. Myuros 4.

Panicle shorter; 1st glume $\frac{1}{2}$ length of 2 nd........ F. bromoides 5.

C. Spikelets compact; outer glumes almost equal; no

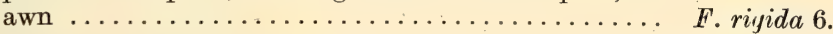

1. F. littoralis, Labill. Leaves erect, cylindrical, straw-colored, rigid, pungent, often exceeding the panicle; panicle spikelike, 6-10 cm. long, straw-colored; spikelets few, flat, erect, 14-16 mm. long, 4-6-flowered; outer glumes about $8 \mathrm{~mm}$. long, both sub-5nerved; flowering glume rather longer, sub-7-nerved, ciliate on the nerves towards base, mucronate.-Schedonorus littoralis, Beauv.

Robe and other places near the coast. Summer.

2. F. duriuscula, L. Sheep's Fescue. Rather slender, but the erect stems stiff; leaves short, setaceous, mostly basal ; panicle contracted, $3-10 \mathrm{~cm}$. long, with solitary branches ; spikelets 8-10 mm. long, 6-8-flowered; flowering glume faintly 5-nerved, terminating in an awn about $\frac{1}{2}$ its length.

Barossa and Flinders Ranges. Oct.-Dec.-Also common in Europe and Asia.

* 3. F. elatior, L., var. arundinacea, Hack. Rather tall, with flat scabrous leaves ; panicle loose, 10-30 cm. long; spikelets $10-14 \mathrm{~mm}$. long, 4-8-flowered; flowering glume $8 \mathrm{~mm}$. long, faintly 5 -nerved, the central nerve excurrent in a very short point or awn.

Moist plains in South-East. Nov.-Jan.-Europe.

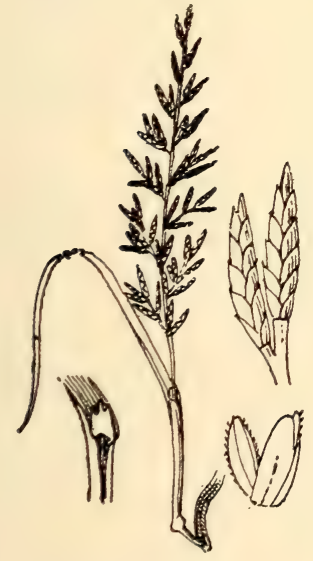

FIG. 21, - Festuca rigida.

* 4. F. Myuros, L. Rat's-tail Fescue. Annual with subulate leaves covering the stem to the base of the panicle, which is long, narrow, unilateral and often arched; spikelets flat, with 4-6 divergent flowers; outer glumes very unequal, the lower one minute; flowering glume cylindrical, with a terminal awn rather longer than it.-Vulpia Myuros, Gmel.

Throughout the State. Sept.-Nov.-Almost cosmopolitan.

* 5. F. bromoides, L. Differs from the preceding in having a long naked stem below the panicle, which is shorter; 1st glume about $\frac{1}{2}$ as long as the 2nd.-Vulpia bromoides, S. F. Gray.

Same places and season.

* 6. F. rigida (L.) Kunth. Hard Fescue. Small stiff annual, with narrow leaves; panicle narrow, oblong. unilateral, rather compact, 4-8 cm. long; spikelets linear, 6-10-flowered; outer glumes almost equal; flowering glumes obtuse, scarcely $2 \mathrm{~mm}$. long.-Scleropoa riıida, Griseb.

A common weed. Sept.-Nov.-Europe ; Asia. 


\section{BROMUS, L.}

(Greek bromos, some kind of oat.)

Spikelets several-flowered, paniculate; outer glumes 2, unequal, shorter than the flowers ; flowering glume rounded or rarely keeled on the back, with 5 or more nerves, awned a little below the kifid summit; palea strongly ciliate on the nerves; styles inserted on one side of the pubescent summit of the ovary ; grain linear-oblong, adhering to the palea.

A. Spikelets expanded at top after flowering, owing to the divergent flowers.

B. 1st glume 1-nerved, 2nd 3-nerved.

C. Panicle very long and loose ............. maximus 1

C. Panicle shorter, compact.

Panicle somewhat loose; stem glabrous ........

Panicle very dense ; stem pubescent ...........

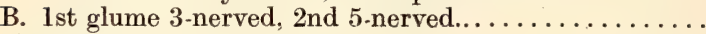

A. Spikelets contracted at top, even after flowering; outer glumes several-nerved.

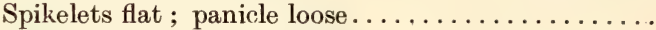

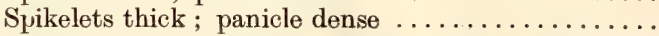

\section{B. madritensis 2 . \\ B. rubens 3 .}

B. arenarius 4 .

\section{B. unioloides 5.}

B. mollis 6 .

* 1. B. maximus, Desf. Great Brome. Erect annual with pubescent stems ; leaves villous; panicle rather loose, erect or drooping at top; spikelets scabrous, 6-10 cm. long with the awns, 6-10-flowered; flowering glume with 7 prominent nerves and an awn about twice its length.

Throughout the settled districts. A form with very stiff, rough awns (B. rigidus, Roth), is known in the country as "Jabbers," Oct.-Nov.-Europe.

* 2. B. madritensis, L. Madrid Brome. Slender annual with glabrous stems; leaves pubescent; panicle turning purple, rather dense, with short branches; spikelets $3-5 \mathrm{~cm}$. long with the awns, 7-12-flowered; flowering glumes narrow, faintly 7 -nerved and finally curved outwards; awn slender, a little longer than glume.

Common at least as far north as Quorn. Oct.-Nov. -Mediterranean region.

* B. rubens, L. Red Brome. Near the preceding, but has pubescent stems and a very dense ovoid purplish panicle. with very short branches; the same divergent and scabrous flowering glumes and slender awns.

From Jamestown northwards, at least as far as Marree ; Eyre Peninsula. Sept.-Nov.-Mediterranean region.

4. B. arenarius, Labill. Sand brome. Annual, with soft, densely pubescent or villous leaves; panicle loose, drooping; spikelets $3-4 \mathrm{~cm}$. long with the awns, pale or purplish, 6-14-flowered; 1st glume 3-nerved, 2nd 5-nerved, sometimes sub-7-nerved; flowering glume 7-nerved, with a slender awn about its own length.

Throughout the State, from the sea-coast to the Far North but not common. Aug.-Oct.

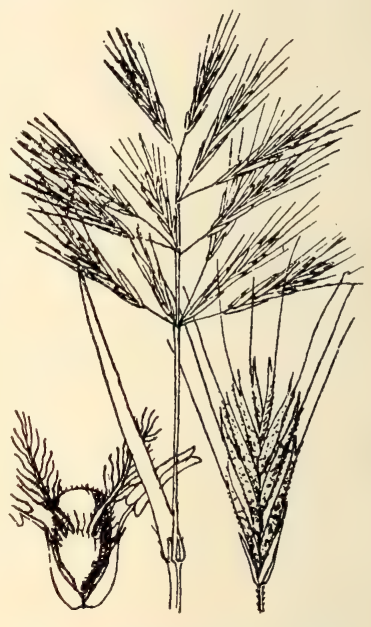

FIG. 22.-Bromus madritensis.

*5. B. unioloides, H. B. et K. Prairie-grass. Stout annual or biennial ; lower leafsheaths villous; panicle long, loose, pyramidal, spikelets very flat, narrowed towards summit, 6-8-flowered; 1st glume 7-nerved, 2nd 9-nerved ; flowering glume keeled, 9-13nerved, with a very short awn ; ovary 3 -horned.

Settled districts. Oct.-Jan.-North and South America.

*6. B. mollis, L. Soft Brome. Annual, with softly villous leaves; panicle ovoid or oblong, dense after flowering, erect, with branches shorter than the spikelets; which are pubescent or glabrous, 5-11-flowered; 1st glume 5-nerved, the 2nd 7-nerved; flowering glume 7-nerved, with an awn nearly as long as itself.

Settled districts. Oct.-Jan.-Europe.

\section{BRACHYPODIUM, Beauv.}

(Greek brakhys, short ; podion, a little foot : the pedicels of the spikelets are very short.)

*1. B. distachyum, R. et S. Small annual, with kneed stems and pubescent nodes; leaves flat, short; spikelets very slightly compressed, 7-15-flowered, 2-4 subsessile in a short erect spike; outer glumes unequal, the 1st 5 -nerved, the 2 nd 7 -nerved; flowering glumes convex on the back, conspicuously 7-nerved, stiff, with a straight terminal awn longer than the glume; palea nearly as long, ciliate; ovary hairy at top.

Adelaide plains; Mount Lofty Range. Oct.-Dec.-Mediterranean region.

Tribe 9.-Chlorideae. Spikelets 1 or several-flowered, sessile or subsessile in 2 rows and forming a 1-sided spike; the rhachis of the spike not articulate. 
68. CYNODON, Rich.

(Greek kynodōn, dog's-tooth : a translation of chiendent, the French name of this grass.)

1. C. dactylon, Rich. Couch-grass. Perennial, with creeping stems and short usually flat leaves; spikelets small, 1-flowered, sessile in 2 rows on one side of the flattened rhachis of 2-5 slender spikes, digitate at the top of the stem ; flowering glume boat-shaped, keeled, awnless, longer than the outer glumes.

Southern districts, usually in moist places. Summer.-A cosmopolitan grass.

C. ciliaris, Benth., which has 2 spikes, the flowering glume shorter than the outer ones, and with a ring of spreading hairs near the top, has been found at Charlotte Waters, and probably exists in our Far North.

\section{CHLORIS, Swartz.}

(Greek khtorros, green : alluding to the leaves.)

Spikelets with 1 bisexual flower, sessile, or shortly pedicellate, alternately arranged in 2 rows on one side of spikes which are digitate at the top of the stem; outer glumes 2 , persistant; flowering glume with a straight terminal awn; above the bisexual flower are 1 or rarely more stalked empty terminal glumes. Perennials.

A. Flowering and terminal glumes acute.

Spikelets crowded .................. Ch. divaricata 1.

Spikelets rather distant .............. Ch. acicularis 2.

A. Flowering and terminal glumes obtuse.

Flowering glume glabrous .............. Ch. truncata 3 .

Flowering glume bearded $\ldots \ldots \ldots \ldots \ldots \ldots \ldots$ Ch. barbata 4.

A. Flowering and terminal glumes broad. scarious ....... Ch. scariosa 5 .

1. Ch. divaricata, R. Br., var. minor, J. M. Black. Short, glabrous ; spikes 4-6, 3-6 cm. long, finally divaricate, spikelets close together (about $1 \mathrm{~mm}$. apart); flowering glume narrow, $5 \mathrm{~mm}$. long, with an awn 10-17 $\mathrm{mm}$. long between the 2 short lobes of the glume ; terminal glume 2 -lobed, with an awn of $5-10 \mathrm{~mm}$.

Flinders Range and Far North. Summer.

Plate 4.-(2) $a$, barren flower; $b$, fertile flower.

2. Ch. acicularis, Lindl. Spider Grass. Erect to $1 \mathrm{~m}$. high; spikes $3-12,7-16 \mathrm{~cm}$. long ; spikelets less close together $(2-3 \mathrm{~mm}$. apart); flowers as in the preceding, but the terminal lobes less conspicuous and often not reaching to the base of the awn, which is more spreading.

River Murray; Flinders Range; Far North.

3. Ch. truncata, R. Br. Star Grass. Variable in height; leafsheaths broad; spikes 5-10, 4-15 cm. long; spikelets shortly pedicellate, $3 \mathrm{~mm}$. long; both the flowering and terminal empty glumes truncate and notched, with slender awns of 6-12 mm.

From Adelaide northwards at least as far as northern end of Flinders Range. Summer.

4. Ch. barbata, Swartz, var. decora, Benth. Near the preceding, but the spikes are denser and the flowering glume has a tuft of long hairs near the summit on each side, and the outer nerve is ciliate ; spikes $6-15,3-6 \mathrm{~cm}$. long.

North of Oodnadatta.

5. Ch. scariosa, F. v. M. Spikes $3-6,2 \frac{1}{2}-3 \mathrm{~cm}$. long; flowering glume raised on a hairy stalk, broad, ciliate with long hairs near the hyaline entire summit, below which rises a fine awn; terminal empty glumes usually 4, the lowest 2 ovate, 5-nerved, spreading, rigid, whitish, the upper ones smaller.

Near Oodnadatta.

\section{ASTREBLA, F. v. M.}

(Greek $a$, not ; streblos, twisted : referring to the awn.)

Spikelets 3-6-flowered, sessile or nearly so in the alternate notches of the rhachis of 1 or 2 unilateral terminal spikes; outer glumes 2, acute, many-nerved, persistant ; flowering glumes silky-hairy, 3-lobed, the lateral lobes erect and rigid, the central lobe tapering into an awn.

Spikes 3-10 cm. ; awn very little longer than lateral lobes.. A. pectinata 1.

Spike 10-15 cm.; awn much exceeding lateral lobes...... A. triticoides 2.

1. A. pectinata, F. v. M. Mitchell Grass. Leaves flat: spike $3-10 \mathrm{~cm}$. long, rather broad, the spikelets close together; flowering glume villous except on the lanceolate lateral lobes, which are slightly exceeded by the central awn.

Far North, and westward to the Musgrave Ranges. Spring and summer. 
2. A. triticoides, F. v. M. Mitchell Grass. Spikes $10-20 \mathrm{~cm}$. long, narrower, the spikelets more distant, the rhachis flexuose ; the awn considerably longer than the lateral lobes.

Flinders Range and Far North.

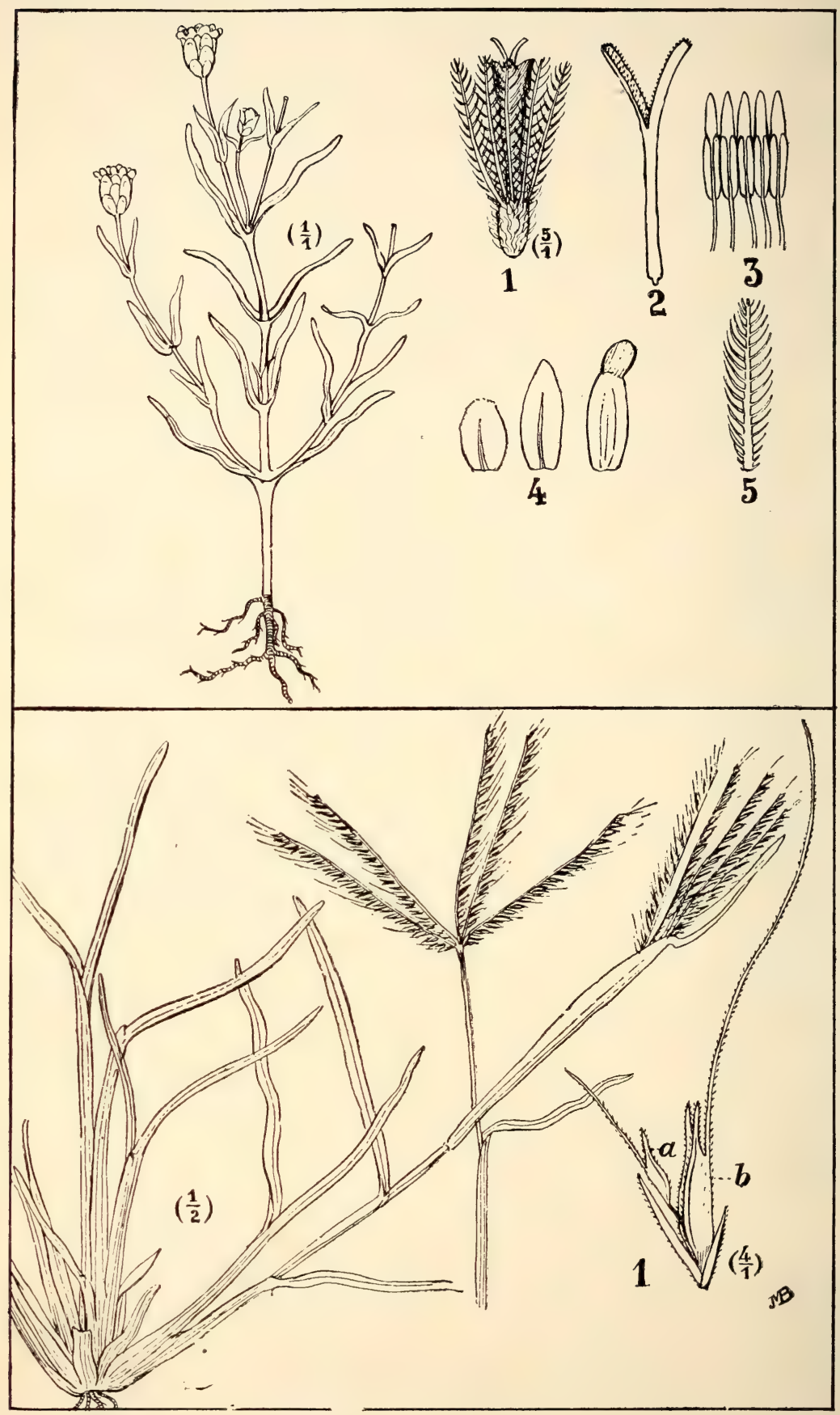

Plate 4.-.(1) Helipterum oppositifolium, S. Moore; (2) Chloris divaricata, R. Br. var. minor, J. M. Black. 


\section{DACTYLOCTENIUM, Willd.}

(Greek daktylos, finger; ktenion, a little comb: the spikes are digitate and comblike.)

1. D. aegyptium, (L.), Willd. Short annual; leaves flat, with a few hairs seated on tubercles; spikelets 3-4-flowered, arranged alternately and closely in 2 rows along one side of the rhachis of 4-10 short digitate spikes; rhachis ending in a naked point; outer glumes 2, shorter than the flowers ; flowering glumes broad, keeled, pointed ; seed rugose, at first enclosed in a loose pericarp._Eleusine aegyptiaca, Pers.; E. cruciata, Lamk.

Far North and West. Spring and summer. Common in most warm countries.

\section{LEPTOCHLOA, Beauv.}

(Greek leptos, slender ; khloe, grass.)

1. L. digitata (R. Br.) comb. nov. Stems stout, rigid, tall; leaves short; spikelets 5-6-flowered, 3-4 mm. long, sessile in 2 rows on one side of 6-20 slender spikes, $5-10 \mathrm{~cm}$. long, apparently digitate like those of Chloris, but really arranged in whorls or rising separately from near the top of the stem; outer glumes much shorter than the flowers : grain smooth -L. subdigitata, Trin. ; Eleusine diyitata, Spreng.

Near Oodnadatta.

Tribe 10.-Hordeeae. Spikelets 1 or several-flowered, sessile, in 2 opposite rows on the rhachis of a simple spike.

\section{LOLIUM, L.}

(Latin name for Darnel.)

Spikelets several-flowered, solitary, sessile in the alternate notches of the rhachis of a spike and appressed to it by one of their sides (backs of the glumes); outer glume 1 except in the terminal spikelet, stiff, convex, several-nerved; flowering glumes 5-nerved ; grain adhering to the palea.

A. Flowers oblong, swollen in fruit ............ Lemulentum 1 .

A. Flowers lanceolete, not swollen in fruit.

Perennial ; outer glume much shorter than flowers ... L. perenne 2.

Annual ; outer glumes equal to or longer than flowers L. sululatum 3.

* 1. L. temulentum, L. Darnel ; Drake. Glabrous annual, with a stiff, stout spike ; spikelet oblong-cuncate, 3-9-flowered, broad-topped in fruit; outer glume equalling or larger than the flowers; flowering glume awnless or awned below the suminit, coriaceous, narrower than the palea.

Settled districts. Oct.-Jan.-Europe ; Asia.

* 2. L. perenne, L. Rye-yrass. Perennial ; outer glume shorter than flowers ; spikelets 3-12-flowered, lanceolate in outline; flowering glume membranous, awnless.

Settled districts. Oct.-Mar.-Temperate parts of the globe.

The cultivated variety or species (L. italicum, A. Braun) has awned flowering glumes and sometimes more numerous flowers. Italian Rye-grass.

* 3. L. subulatum, Vis. Stiff annual, resembling Lepturus cylindricus ; spike thick and long; spikelets lanceolate, 3-6-flowered ; outer glume equal to or longer than the flowers ;. flowering glume membranous, awnless, or with a very short awn or point._L. rigidum, Gaudin var. subulatum, Fiori.

Settled districts. Oct.-Dec.-Mediterranean region.

\section{LEPTURUS, R. Br.}

(Greek leptos, slender; oura, tail : alluding to the slender spikes.)

Spikelets 1-flowered, sessile, solitary and half-imbedded in the alternate notches of a slender fragile spike; outer glumes 1 or 2, stiff, 5-nerved; flowering glume shorter, hyaline. Annuals.

Outer glumes $2 \ldots \ldots \ldots \ldots \ldots \ldots \ldots \ldots \ldots \ldots \ldots \ldots \ldots \ldots \ldots \ldots \ldots \ldots \ldots$ incurvatus 1.

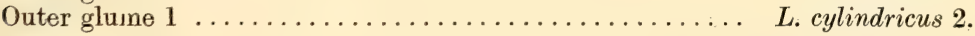

1. L. incurvatus, Trin. Spikes slender, acute, cylindrical, stiff, usually curved ; outer glumes 2 in all the lateral spikelets, placed side by side and one partially overlapping the other.

Near salt or fresh water in all districts except the Far North. Oct.-Dec.--Also European.

2. L. eylindricus, Trin. Like the preceding, but the spikes rather thicker and usually straight; the lateral spikelets have 1 outer empty glume, only the terminal one having 2.

Southern districts and South-East. Oct.-Jan.-Also European. 


\section{AGROPYRUM, Beauv.}

(Greek ayros, a field ; pyros, wheat : "wild wheat.")

Spikelets several-flowered, compressed, solitary and sessile in alternate notches of the rhachis of a spike, one face of the spikelet (sides of the glumes) appressed to the rhachis ; outer glumes 2, shorter than the flowers; flowering glumes rounded on back with usually 5 nerves converging at summit; ovary pubescent at top.
Spikelets broad, long-awned ................. A. scabrum 1.
Spikelets narrow, short-awned................ A. repens 2.

1. A. scabrum (Labill.), Beauv. Variable perennial, sometimes over $1 \mathrm{~m}$. high; leaves scabrous on edges, more or less hairy ; spikelets distant, 6-12-flowered, on a fragile axis, $5.7 \mathrm{~cm}$. long with the scabrous awns, which are $2-4 \mathrm{~cm}$. long, the upper flowers and awns finally divergent; flowering glumes narrow, rigid.

Throughout the State as far north as the Flinders Range. Oct.-Dec.

*2. A. repens (L.), Beauv. English Courh-yrass. Perennial with creeping rootstock ; leaves scabrous on upper face ; spikelets thick, rather distant on a stiff axis, 4-6-flowered; outer glumes half or more as long as the flowering glumes, which are 5-nerved near the summit and usually taper into a short stiff awn.

Here and there in settled districts. Oct.-Jan.-Europe; Asia.

\section{HORDEUM, L.}

(Latin name for Barley.)

Spikelets 1 -flowered, subcylindrical, arranged side by side in 3 's in the alternate notches of the fragile rhachis of a dense cylindrical spike; outer glumes 2, narrow, awned, placed side by side in front of the spikelet; flowering glume convex, 5-nerved, long-awned ; grain hairy at top, adherent to the flowering glume and palea.

Leaf-sheaths glabrous; central outer glumes dilated and

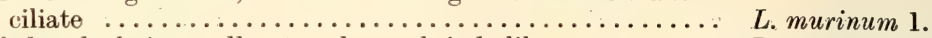

Leaf-sheaths hairy; all outer glumes bristle-like......... L. maritimum 2.

*1. H. murinum, L. Barley-yrass. Annual, with villous leaf-blades but glabrous sheaths; spike $3.10 \mathrm{~cm}$. long, bristly ; central spikelet of the trio fertile, with the outer glumes lanceolate and eiliate, the 2 lateral spikelets barren, with 1 or both outer glumes resembling bristles; flowering glumes tapering into awns 3 times their length and much longer than the outer glumes.

Throughout the State. Oct.-Dec.-Cosmopolitan.

*2. H. maritimum, With. Sea Barley. Resembles the preceding but the spikes are smaller, the sheaths of the lower leaves pubescent, the upper leaves glabrous; the 2 lateral spikelets have awns shorter than their outer glumes, and all the outer glumes are bristle-like and not dilated or ciliate.

Sea-coasts, and also inland at such places as Jamestown and Bordertown. Oct.-Dec.Europe.

\section{FAMILY 21.-CYPERACEAE.}

Flowers bisexual or unisexual in little spikelets consisting of several scale-like bracts called glumes; perianth none or reduced to hypogynous bristles or scales; stamens usually 1-3, rarely 4 or 6 ; anthers basifixed, 2-celled; ovary free, 1-celled, with 1 erect anatropous ovule; style divided into 2-3 stigmatic branches; fruit an indehiscent dry nut (achene), flattened when the style is 2-branched, trigonous when it is 3-branched; seed erect, albuminous; stems usually solid, often trigonous : leaves narrow, with closed tubular sheaths. Grass or rush-like herhs usually perennial. The Sedye Family.

A. Flowers bisexual; fruits more than 1 in each spikelet.

B. Glumes in 2 opposite rows (distichous).

C. All glumes fruit-bearing except 1 or 2 at base .....

C. Barren glumes usually several.

Flowers 2 or more, bract usually 1 , narrow ....

Flowers 2; involucral bracts with very broad

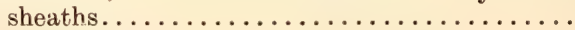

B. Glumes inbricate all round the rhachilla.

D. Base of style thickened.

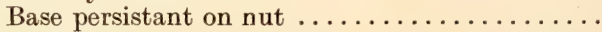

Base deciduous from nut $\ldots \ldots \ldots \ldots \ldots \ldots$

D. Base of style not thickened.

Hypogynous bristles or scales absent or 3-6 $\ldots$.

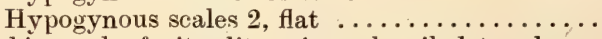

\section{Cyperus 1.}

SchoEnus 2.

Gymnoschoenus 3.

HELEOCHARIS 4.

FIMBRISTYLIS 5 .

ScIRPus 6.

LIPOCARPHA 7.

A. Flowers bisexual ; fruit solitary in each spikelet; glumes inbricate all round.

E. No hypogynous bristles or scales. 
F. Spikelets paniculate.

Lowest flower fertile ............... Cladium 9.

Lowest flower sterile $\ldots \ldots \ldots \ldots \ldots \ldots$ Gahnia 10.

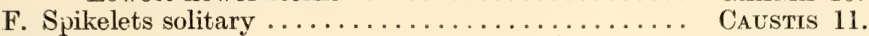

E. Hypogynous scales $6 \ldots \ldots \ldots \ldots \ldots \ldots \ldots \ldots \ldots \ldots \ldots \ldots \ldots \ldots$ Lepidosperma 12.

A. Flowers unisexual; glumes imbricate all round.

Nut enclosed in a utricle ................ CAREX 13.

Nut not enclosed in a utricle .............. ChORIzandra 8.

\section{CYPERUS, L.}

(Latin, from Greek kypeiros, sorne species of Sedge.)

Spikelets several flowered, with distichous glumes; stainens 1-3; styles 2- or 3-fid; no hypogynous bristles. Usually perennials with simple stems; spikelets in sessile heads, or on the rays (branches) of an umbel, having at the base an involucre of leafy bracts.

A. Style 2-cleft; rhachilla not winged.

B. Nut compressed laterally (with 1 edge next rhachilla) C. Eragrostis 1.

B. Nut compressed dorsally (with the flat or concave face next rhachilla).

Dwarf annual ; spikelets numerous in a head.......

Perennial ; spikelets 1 or 2 together.............

A. Style 3-cleft; rhachilla not or scarcely winged; spikelets capitate or clustered.

C. Spikelets few, pale-colored in a single sessile cluster ; small annuals.

D. One involucral bract erect $\ldots \ldots \ldots \ldots \ldots \ldots \ldots$

D. Involucral bracts spreading.

Glumes nerveless on sides.............. Glumes nerved on sides . . . . . . . . . . . .

C. Spikelets numerous; glumes with recurved points;

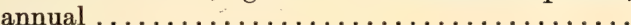

C. Rather tall perennials.

E. Nut not $\frac{1}{2}$ as long as glume ; bracts $3-9$, almost

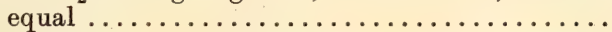

E. Nut as long as glume; spikelets small, capitate; bracts $1-3 \ldots \ldots \ldots \ldots \ldots \ldots \ldots \ldots \ldots$

E. Nut shorter than glume; stems trigonous; 2 involucral bracts long.

Spikelets in umbellate heads . .............

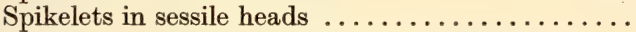

A. Style 3-cleft; spikelets spicate on the umbel-rays.

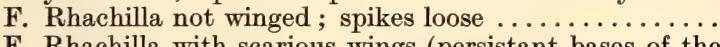

F. Rhachilla with scarious wings (persistant bases of the glumes).

G. Stems stout, acutely 3 -angled.

Umbel small; spikelets $10-30 \mathrm{~mm} . . . \ldots \ldots \ldots$

Umbel large; spikelets $8-12 \mathrm{~mm} . \quad \ldots \ldots \ldots \ldots$.

G. Stems slender, acutely 3 -angled.

Rootstock bearing tubers; spikelets flat ......

Rootstock without tubers; spikelets scarcely

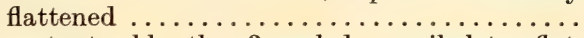

G. Stems stout, bluntly 3 -angled; spikelets flat,

reddish-brown................................... 16 .

C. pygmaeus 2 .

C. distachyus 3 .

\section{C. tenellus 4 .}

C. enervis 5.

C. gracilis 6 .

C. squarrosus 7.

\section{C. vaginatus 8 .}

C. difformis 9 .
C. fulvus 10.

C. Gilesii 11.

\section{Iria 12 .}

\section{C. alterniflorus 13 .}

C. exaltatus 17.

C. rotundus 14 .

C. subulatus 15.

1. C. Eragrostis, Vahl. Leaves shorter than stem; spikelets usually in a compound umbel, with 2-4 involucral bracts; spikelets flat, dark-brown, 12-24-flowered, 6-12 $\mathrm{mm}$. long; glumes obtuse with a green keel and nerveless sides; nut less than $\frac{1}{2}$ the length of the glume, biconvex.

Recorded by Bentham for "Torrens River, F. Mueller," but does not appear to have been found since.

2. C. pygmaeus, Rottb. Low annual, with narrow leaves ; spikelets small and numerous crowded into a globular compound head with 3-5 broad-based involucral bracts far surpassing it; style 2 or rarely 3-cleft; nut ovoid, shorter than glume, plano-convex or trigonous.

River Murray, on moist ground. Summer.

3. C. distachyus, All. Slender perennial ; leaves very short or reduced to sheaths at the base; spikelets solitary or twin, dark-brown, 6-24-flowered; involucral bracts 2 , the lower one long, erect; nut much shorter than glume, plano-convex.

Country about Lakes Torrens and Eyre. Spring.-Also in the Mediterranean region. 
Plate. 5.-Fig. (1) 1, spikelet; 2, glume ; 3, glume and nut ; 4, pistil and stamens.

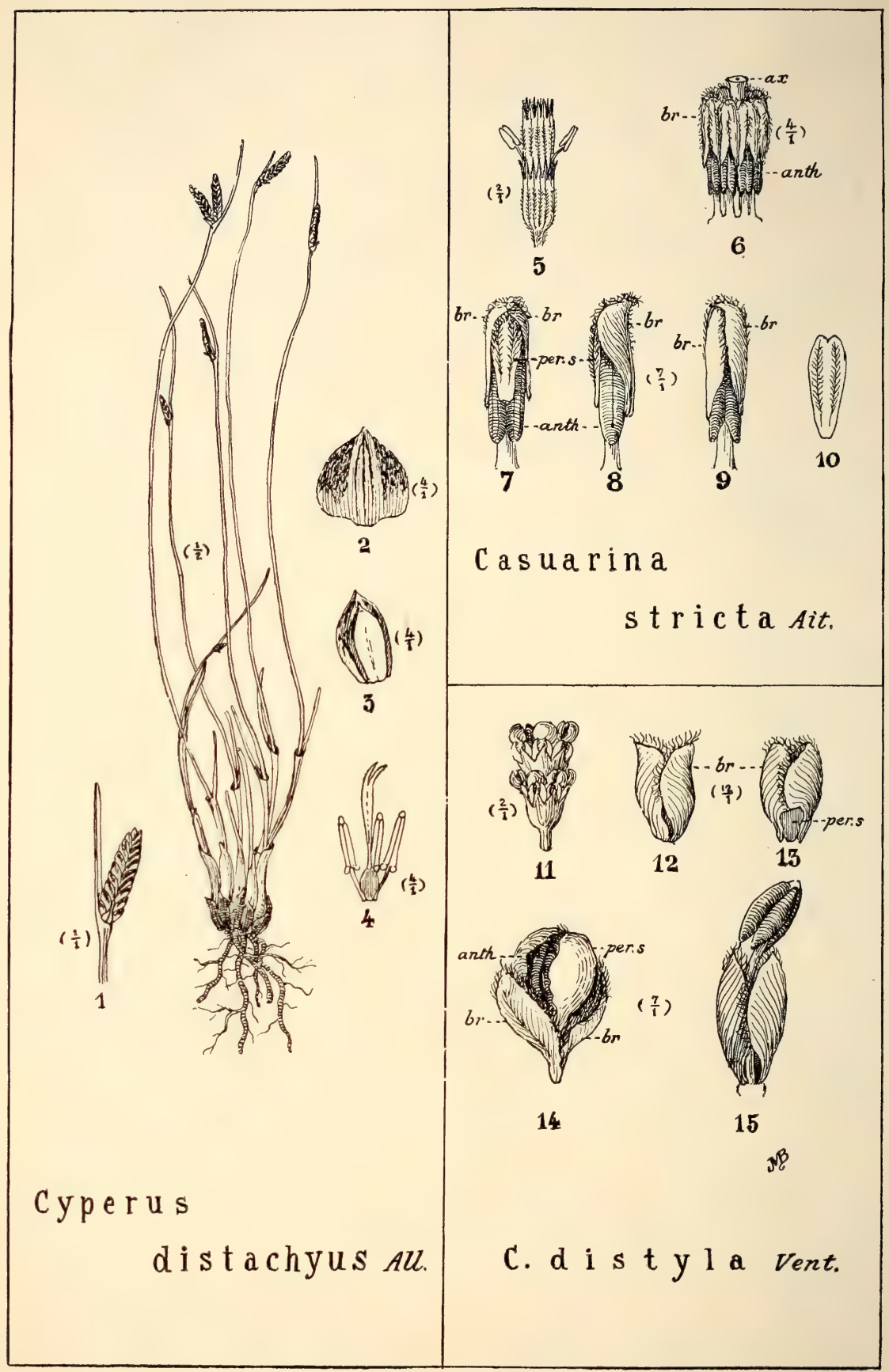

Plate 5.-(1) Cyperus distachyus ; (2) Casuarina stricta ; (3) C. distyla.

4. C. tenellus, L. f. Dwarf annual, with filiform stems and leaves; spikelets 1-3 together, flat, 10-24-flowered, the involucral bract erect; glumes keeled, with about 4 prominent nerves on each side; nut trigonous, more than $\frac{1}{2}$ as long as glume.

Mount Lofty and Barossa Ranges; South-East. Summer. 
5. C. enervis, R. Br. Resembles $C$. gracilis, but the spikelets are 6-14 mm. long, 12-24flowered; glumes mucronate, with 2 nerves on each side of and close to the keel, the broad sides nerveless.

River Murray ; Flinders Range. Summer.

6. C. gracilis, R. Br. Small perennial, with filiform leaves; spikelets 4-6 mm. long 3-4 mm. broad, 6-12-flowered, few together, with 3 filiform very long involucral bracts; glumes with a short spreading point and 3-4 nerves on each side; nut thick, trigonous, nearly as long as glume.

Far North. Spring.

7, C. squarrosus, L. Small annual; leaves narrow or rather broad; spikelets flat, linear, 4-10 mm. long, 10-20-flowered, numerous in dense heads or umbellate, with 2-4 involucral bracts; glumes 5-7-nerved, tapering into a long, recurved point; nut about $\frac{1}{2}$ as long as glume.

Far North. Spring.

8. C. vaginatus, $\mathrm{R}$. Br. Variable perennial, leafless except for brown sheaths at base of the rigid cylindrical stems; spikelets very flat, reddish-brown, lanceolate or linear, 5-14 mm. long, 2-3 mm. broad, 8-40-flowered, either in a dense compound cluster with 3-5 short rigid involucral bracts and striate stems (var. densiflorus, Benth.), or clustered on the rays of a simple umbel with 6 , rarely 7-9 broad involucral bracts $2-25 \mathrm{~cm}$. long, almost equal; glumes $2-3 \mathrm{~mm}$. long, acute, with broad brown nerveless sides, closely imbricate; nut about $\frac{1}{2}$ as long as the glume, trigonous.

Throughout the State. Summer.

9. C. difformis, L. Leaves flat, long; spikelets dark-red, linear, 2-4 mm. long, scarcely $1 \mathrm{~mm}$. broad, 8-18-flowered, in dense globular heads, sessile or on the slender rays of an umbel; involucral bracts 1-3, leafy; nut trigonous, ovoid, nearly as long as the small, broad glume.

Murray country and Far North. Spring and summer.

10. C. fulvus, R. Br. Stems trigonous; leaves rather narrow, long, rather scabrous ; spikelets $6-12$ in clusters on a simple umbel of $4-6$ rays ; 2 involucral bracts much longer than inflorescence, and 1 or 2 shorter; spikelets golden or reddish-brown, 8-16-flowered ; glumes loosely imbricate, 3-4 mm. long, with 2-3 prominent nerves on each side of keel; nut trigonous, more than $\frac{1}{2}$ as long as glume.

Everard and Musgrave Ranges. Spring.

11. C. Gilesii, Benth. Resembles the preceding in the spikelets and loose glumes, of a golden color, but the spikelets are longer (8-20 mm.), 20-40-flowered, usually arranged in a sessile cluster, and the glumes are finely pointed, the lower ones deciduous ; involucral bracts about 3,2 longer than the inflorescence ; stems trigonous ; nut more than $\frac{1}{2}$ as long as glume.

Far North. Spring.

12. C. Iria, L. Stem triquetrous; leaves flaccid ; spikelets 5-15 mm. long, flat, goldenbrown, 6-20-flowered, spicate on the umbel-rays; involucral bracts 2-4; glumes obtuse, 5-nerved on keel, the lower ones deciduous, nut trigonous, a little shorter than glume.

Far North. Spring.

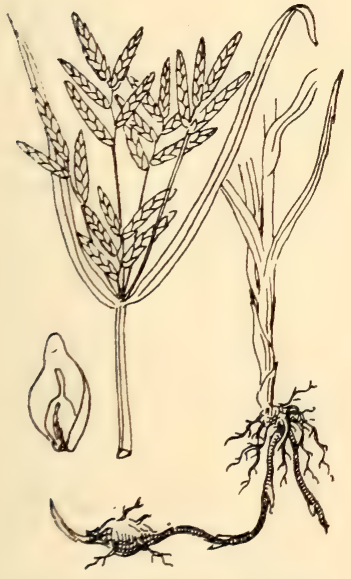

FIG 23.-Cyperus rotundus.
13. C. alterniflorus, R. Br. Stem triquetrous; leaves long, with scabrous edges; spikelets spreading, golden or reddish-brown, 10-30 mm. long, 12-34-flowered, spicate on few rays of a simple or compound umbel; involucral bracts about 4, 1 or 2 very long, scabrous; glumes $4 \mathrm{~mm}$. long, loosely imbricate, with 3 nerves on each side of keel ; nut triquetrous, oblong, more than $\frac{1}{2}$ as long as glume.

River Murray; Flinders Range and Far North. Spring.

14. C. rotundus, L. Vut-grass. Rootstock tuberous; leaves tapering, shorter or longer than the triquetrous stem; spikelets from pale-yellow to dark-brown, flat, acute, $10-15 \mathrm{~mm}$. long, about 16 -flowered, in short spikes on the 4-8 unequal rays of an umbel, or almost contracted into a cluster ; involucral bracts 2.4; glumes with 4 nerves on each side of the keel, closely imbricate; nut triquetrous. scarcely $\frac{1}{2}$ the length of the glume.

Far North; in the South it is a bad weed in gardens and parks, and probably introduced. Summer.-Almost. cosmopolitan.

15. C. subulatus, $\mathrm{R}$. Br. Differs from the preceding by a rootstock without tubers.

Recorded by Bentham for Lake Eyre. 
16. C. Gunnii, Hook. f. Stem triquetrous, rather stout and tall; leaves long and scabrous on margin; spikelets flat, reddish-brown, 5-12 mm. long, 6-12-flowered in dense heads or very short spikes on the rays of a simple or compound umbel, the longest rays 7-8 $\mathrm{cm}$. long: involucral bracts $2-3$, very long (sometimes to $1 \mathrm{~m}$.), and 1 or 2 smaller, all scabrous; glumes $3-4 \mathrm{~mm}$. long, with $2 \cdot 3$ prominent nerves on each side of keel, loosely imbricate; nut triquetrous, $\frac{3}{4}$ length of glume.

Mount Lofty and Flinders Ranges; Mount Gambier in moist places. Summer.

17. C. exaltatus Retz. Stem tall, stout, triquetrous; leaves broad, scabrous on margin ; spikelets numerous, golden, linear, 8-12 mm. long, 14-30-flowered, spicate on the rays of a large compound umbel; rhachilla distinctly winged ; 2 or 3 of the involucral bracts much longer than the umbel; glumes obtuse, mucronate, 3-nerved on keel, the lower deciduous; nut trigonous, $\frac{1}{2}$ as long as glume.

River Murray; Far North, near waterholes. Spring and Summer.

Var. minor. Umbel smaller; spikelets $3 \mathrm{~mm}$. long, 6-flowered. River Murray.

\section{SCHOENUS, L.}

(Latin for some grass or reed, from Greek skhoinos.)

Spikelets 2-5-flowered, capitate or paniculate, the uppermost flower often male or sterile; glumes distichous, some of the outer ones empty; stamens usually 3 ; stylebranches 3 ; nut more or less trigonous or 3-ribbed ; rhachilla flexuose between the flowers ; hypogynous bristles rarely absent. Perennials.

A. Stems with leafy bracts and filiform basal leaves.

B. Spikelets minute, with 1 fertile flower ........... S. axillaris 1 .

B. Spikelets $4-6 \mathrm{~mm}$. long, in terminal and axillary ('lusters.

Spikelets lark-brown.

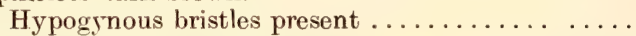

Hyjogvnous bristles absent. . . . . . . . . . . . .

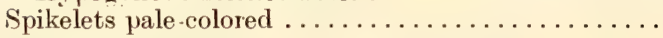

S. apoyon 2.

S. tesquorum 3.

A. Leaves only at base of stem; small plants.

C. Hypogynous bristles present.

Leafsheaths densely bearded $\ldots \ldots \ldots \ldots \ldots \ldots$

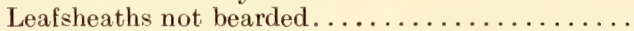

C. Hypogynous bristles absent; dwarf plants.

Fertile flower 1 ; nut wrinkled .............

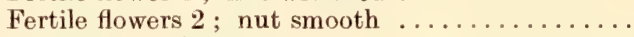

S. sculptus 4 .

\section{S. deformis 5.}

S. nitens 6 .

S. Tepperi 7.

S. discifer 8.

A. Leaves reduced to sheathing bases.

D. No hypogynous bristles: stamens usually 6 .

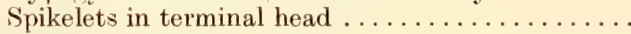

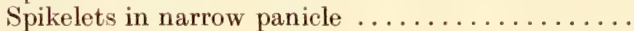

D. Hypogynous bristles 6 ; spikelet solitary ........

S. aphyllus 9 .

S. brevifolius 10 .

S. tenuissimus 11 .

1. S. axillaris (R. Br.), Poir. Small, weak plant with narrow leaves; spikelets 2-3 together in the axils, 2 -flowered, but usually only 1 flower fertile; hypogynous bristles 5-6, slender; nut ovoid, white, 3-ribbed.

Marshy places in Mount Lofty Range; South-East. Sept.-Jan.

2. S. apogon, Roem et Sch. Stems slender, $2-30 \mathrm{~cm}$. high, with filiform leaves ; spikelets dark-brown, 4-6 mm. long, 2-flowered, few together in terminal and axillary clusters; hypogynous bristles 6 ; nut white, globose, 3-ribbed. - S. Brownii, Hook. $\mathrm{f}$.

From South-East to Flinders Range; Eyre Peninsula. Aug.-Dec.

3. S. tesquorum, J. M. Black. Stems filiform compressed, striate, $20-40 \mathrm{~cm}$. high, with 2-3 leafy distant bracts with dark closed sheaths; basal leaves capillary ; spikelets reddish-brown, 6-7 mm. long, 2-flowered, pedicellate in clusters of 2-4, usually 1 cluster terminal and another in the next leafy bract lower down on the stem; hypogynous bristles none; nut white, trigonous, obovoid.

From near Millicent eastward to Nangwarry, S.E.

4. S. sculptus, Boeck. Like the preceding, but the spikelets not so dark and the upper ones sometimes solitary, all 4-5-flowered; hypogynous bristles none, or rarely 2-3 very slender ones; nut ovoid, shortly beaked, white, 3-ribbed and deeply pitted between the ribs.

Kangaroo Island; Eyre Peninsula. Oct.-Nov.

5. S. deformis, R. Br. Small ; leaves at base of stem with sheaths densely bearded at the orifice and short recurved blades; spikelet solitary and terminal, within the sheath of a small bract, 3-4-flowered; hypogynous bristles 6 , densely hairy.

Memory Cove, near Port Lincoln. Does not seem to have been rediscovered since Robt. Brown's day. 
6. S. nitens (R. Br.), Poir. Stems slender, from a creeping rootstock : leaves at base of stem, short, filiform; spikelets brown, 2-3-flowered, solitary or several in a terminal head, with an erect involucral bract continuing the stem; glumes broad, subdistichous; hypogynous bristles 6 , with long hairs towards the base; nut obovoid, shining, trigonous. Jan.

Reedbeds, near Adelaide; Yorke Peninsula; Kangaroo Island; South-East. Nov.-

7. S. Tepperi, F. v. M. Dwarf; leaves basal, filiform, usually curved, longer than the stem, which bears 1 spikelet with 1 fertile flower; no hypogynous bristles; nut white, trigonous, rugulose.

Mount Lofty Ranges; Kangaroo Island; Yorke and Eyre Peninsulas. Summer.

8. S. discifer, Tate. Dwarf ; leaves basal, linear, flat; spikelet with 2 fertile flowers, solitary at summit of short stem and with an erect involucral bract; no bristles ; nut ovoid, raised on a thin disk.

Dudley Peninsula, K.I. Oct.-Dec.

9. S. aphyllus, Boeck. Stems wiry, with brown sheathing bases, glabrous at orifice ; spikelets 2 -flowered, $5 \mathrm{~mm}$. long, in a terminal head, which is equalled or scarcely exceeded by the brown outer involucral bract; no bristles; stamens 3-7; nut obovoid, obtusely trigonous; glumes ciliolate.

From River Murray northwards. Sept.-Jan.

10. S. brevifolius, R. Br. Stems wiry, slightly compressed, 30-40 cm. high, with brown glabrous sheathing bases; spikelets dark-brown, 2-3-flowered, 7-10 mm. long, few and pedicellate in the axils of sheathing bracts with a short, erect, obtuse lamina, forming a narrow panicle $5-10 \mathrm{~cm}$. long; glumes all ciliate; hypogynous bristles 3, very short; nut obovoid.

Myponga. Nov.-Dec.

11. S. tenuissimus (Hook. f.), Benth. Stems filiform, with 2 longitudinal groves; leaves reduced to basal sheaths; spikelets solitary, terminal, erect, $10-15 \mathrm{~mm}$. long, with 1 fertile flower; hypogynous scales 6 ; nut obovoid, smooth.-Lepidospora tenuissima, F. v. M.

Square Waterhole; Encounter Bay; South-East. Summer.

\section{GYMNOSCHOENUS, Nees.}

(Greek gymnos, naked; skhoinos, a reed : alluding to the long naked stems.)

1. G. sphaerocephalus (R. Br.), Hook. f. Stems rigid, slender, over $1 \mathrm{~m}$. high, with long, channelled leaves; spikelets with 2 flowers, the lower male, the upper bisexual, numerous in a dense globular head, with a few broad involucral bracts at base; glumes subdistichous; hypogynous bristles 3, slender; stamens and style-branches 3 ; nut crowned by the base of the style.-Schoenus sphaerocephalus, Poir.

South-East. Oct.-Dec.

\section{HELEOCHARIS, R. Br.}

(Greek helos, heleos, a marsh ; khairū, to delight in.)

Spikelets many-flowered, cylindrical, terminal, solitary, the glumes imbricate all round the rhachilla; hypogynous bristles $3-8$; stamens $1-3$; style-branches $2-3$; nut crowned by the thickened persistant base of the style; leaves reduced to sheathing bases.
A. Stems hollow, stout, apparently articulate ........ H. sphacelata 1.

A. Stems solid, cylindrical.

B. Stems rather slender.

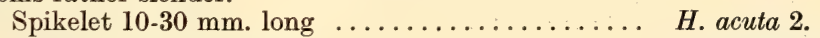

Spikelet $6-10 \mathrm{~mm}$. long ................ Hulticaulis 3 .

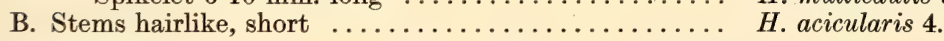

1. H. sphacelata, R. Br. Stems thick, erect, hollow, tall, with transverse partitions, rising from a creeping rootstock; spikelet $3-6 \mathrm{~cm}$. long; glumes flattish, obtuse, stiff ; nut compressed-globose, finely pitted, shorter than the 6-8-bristles.

In marshes throughout the southern districts and South-East, and as far north as the Flinders Range. Nov...Jan.

2. H. acuta, R. Br. Stems slender, usually about $30 \mathrm{~cm}$. high, from a creeping rootstock ; spikelet linear oblong, 1.3 cm. long, acute; glumes almost acute, with a green keel and brown sides; nut biconvex, with 5-6 bristles; upper leaf-sheath truncate, with a minute point.

Near water, from the South-East to the Far North. Sept.-Feb.

3. H. multicaulis, $S^{\prime \prime}$. Stems more slender and often shorter than in the preceding, filiform; leafsheaths obliquely truncate; spikelet oblong, 6.10 $\mathrm{mm}$. long: nut obovoid, prominently 3-ribbed, smooth, surrounded by 5-6 bristles shorter or longer than itself, and crowned by a conical beak.

Mount Lofty Ranges; Kangaroo Island; South-East. Oct...Jan. 
4. H. acicularis (L.), R. Br. Sterns capillary, $3-7 \mathrm{~cm}$. long; leafsheaths truncate ; spikelet 2-4 mm. long, few-flowered; hypogynous bristles small or absent : nut obovoid, 3-ribbed, finely striate.

River Murray. Summer.

\section{FIMBRISTYLIS, Vahl.}

(Latin fimbriae, a fringe ; stylus, style : the whole style is often fringed or ciliate.) Spikelets several-flowered, in heads or irregular umbels; glumes imbricate all round the rhachilla, the lowest 1-4 empty ; no hypogynous bristles; style 2-3-cleft, thickened at base, but articulate on the ovary and wholly deciduous.

A. Stvle-branches 2 ; nut coin pressed.

B. Weak annual; nut smooth ............... F. squarrosa 1.

B. Erect perennials.

Nut striate and wrinkled $\ldots \ldots \ldots \ldots \ldots \ldots \ldots$ F. diphylla 2.

Nut snooth .................... ferruginea 3 .

A. Style-branches 3 .

Spikelets oroid, umbellate ............... Neilsonii 4.

Spikelets linear, clustered .............. F. barbata 5 .

1. F. squarrosa Vahl. A small tufted annual; leaves filiforı, pubescent on the broad sheaths; umbels simple or compound, with involucral bracts equalling or much longer than the inflorescence; spikelets straw-colored, $2.5 \mathrm{~mm}$. long, the glumes pointed and keeled; base of style hairy; nut biconvex, finely striate.-F. velata, R. Br.

River Murray; Warburton River (near Lake Eyre). Summer.

2. F. diphylla, Vahl. Perennial with slender stems, 20-40 cm. high; leaves few, narrow, mostly basal; umbels usually compound and loose with very short involucral bracts; spikelets brown, ovoid-oblong, 5.7 min. long; nut biconvex, whitish, longitudinally striate and transversely rugose under lens; stamens usually 3 ; style ciliate.

Far North. Spring and summer.

3. F. ferruginea, Vahl. Stems angular and less slender; umbel usually simple with few ovoid-oblong spikelets, $10-12 \mathrm{~mm}$. long, the glumes shortly pointed and hoarypubescent; 2 or 3 of the involucral bracts long; stamens 3 ; nut obovoid, biconvex, simooth.

Warburton River (near Lake Eyre). Summer.

4. F. Neilsonii, F. v. M. Spikelets $8-12 \mathrm{~mm}$. long, clustered on the few short rays of a simple umbel; glumes obtuse ; stamens 3 ; style glabrous, 3 -branched : nut trigonous, pear-shaped, tuberculate.

Far North.

¿. F. barbata (R. Br.), Benth. Stems slender, $8-20 \mathrm{~cm}$. high, with short capillary leaves and sheaths bearded at summit; spikelets linear, brown, 4-6 mm. long, 4-10 in a terminal head, exceeded by one of the involucral bracts; stamen usually 1 ; style glabrous, 3 -branched ; nut olovoid, finely granular, the villous base of the style persistant for a long time.

Far North.

\section{SCIRPUS, L.}

(Latin for a reed or rush.)

Spikelets several-flowered, clustered, umbellate, or rarely solitary; glumes imbricate all round the rhachilla, the lowest 1 or 2 sometimes empty ; stamens $1-3$; style deciduous, 2-3-cleft : nut with or without hypogynous bristles.

A. Sinall and slender plants (except $S$. nodosus); no hypogynous bristles (except in $S$. supinus).

B. Style-branches 2 ; spikelets solitary .......... fluitans 1 .

B. Style-branches usually 3 .

C. Stems not rigid; spikelets usually in lateral clusters.

I). Spikelets small (2-4 $\mathrm{mm}$.).

E. Nut furrowed lengthwise ............ s. setaceus 2.

E. Nut granular.

F. Sides of glumes thin.

Spikelets 1-3 ................. Sernuus 3 .

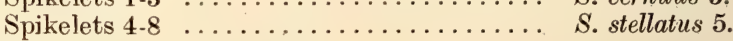

F. Sides of glumes stiff, shining . . . . antarcticus 4 .

D. Spikelets over $4 \mathrm{~mm}$. long.

Nut, white, $\sin 00 t h \ldots \ldots \ldots \ldots \ldots \ldots$ S. inundatus 6.

Nut black, wrinkled .................. S. supinus 7 .

C. Stems rigid; spikelets in a dense head........... nodosus 8.

A. Tall stout plants; hypogynous bristles 3-6.

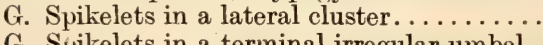

S. americanus 9 .

G. Spikelets in a terminal irregular umbel. 
H. Involucral bract short, erect; style-branches 2 .

Bristles filiform, scabrous ................ lacuster 10 .

Bristles or scales flattish; plumose .......... S. littoralis 11

H. Involucral bracts spreading; stem triangular; style-

branches 3 .................... S. maritimus 12

1. S. fluitans, L. Stems filiform, weak, creeping.or floating; leaves linear, alternate at the nodes; spikelet solitary, terminal, ovoid, $3-4 \mathrm{~min}$. long, few-flowered, the lowest glume longer than the others; stamens 3, sometimes 2 ; nut broad, smooth, whitish, plano-convex.-Isolepis fluitans, R. Br.

In or near water, in southern districts. Sum!ner.

2. S. setaceus, L. Stems filiform, $3-15 \mathrm{~cm}$; ; leafblades very short, filiform ; spikelets 1-3, usually lateral, $3.4 \mathrm{~mm}$. long, the short involucral bract solitary and erect; glumes few, with a green keel and sides turning brown; nut alinost globular, whitish, ribbed longitudinally and striate transversely $\frac{1}{3}-\frac{3}{1} \mathrm{~mm}$. long; stamens 2-3.-Isolepis setasea, $\mathrm{R}$. $\mathrm{Br}$.

Moist spots as far north as Flinders Range. Summer.

3. S. cernuus, Vahl (1806). Resembles the preceding, but the stems are even weaker and often curved; spikelets usually solitary, sometimes 2-3, 2-4 mm. long, with a very short erect, or longer spreading bract; glumes thin, striate, brownish, acute ; stamens $2-3$, or sometimes 1 only, especially in specimens with $2-3$ spikelets; nut $\frac{3}{4} \mathrm{~mm}$. long, obovoid, trigonous, obtuse, but pointed at summit, minutely granular, finally almost black and shining.-S. riparius, Poir (1820); Isolepis riparia, R. Br. (1810).

Common in southern districts near water. Summer.

4. S. antareticus, L. Usually a neat little tufted plant $3-6 \mathrm{~cm}$. high, sometimes taller ; leaves short linear; spikelets 1-6, few-flowered, 3-4 mm. long, with an erect or spreading bract longer than the cluster; glumes boatshaped, stiff and shining, with a green keel, the sides with curved nerves and a reddish-brown spot; nut obovoid, trigonous, $1 \mathrm{~mm}$. long, finely granular, obtuse at summit, and sometimes with a minute blunt point, at first yellow, becoming brown, not shining; stamens 2-3.-S. cartilagineus, Poir; Isolepis cartilaginea, R. Br. Dec.

Throughout the State, at least as far as the northern part of the Flinders Range. Sept.-

5. S. stellatus, C. B. Clarke. Stems, leaves, and bract like the preceding, but the spikelets are in clusters of 4-8, the glumes greenish with a short spreading point ; nut obovoid, triquetrous, $\frac{3}{4} \mathrm{~mm}$. long, with a conical point, minutely granular, black, shining.

Naracoorte; Penola. Summer.

6. S. inundatus (R. Br.), Poir. Stems usually long and rather stout, but flaccid; leafsheath basal, with a short point; spikelets 4-6 mm. long, usually 3-12 in a cluster, which is often proliferous ; glumes rather numerous, with a green keel and striate brown sides ; stamen 1 ; nut $1 \frac{1}{4} \mathrm{~mm}$. long, trigonous or plano-convex, obtuse but pointed, white, smooth and shining.

In marshes or beside water in the southern districts and South-East. Summer.

7. S. supinus, L. Stems tufted, spreading or ascending ; basal leafsheaths terminating in a short blade; spikelets 1-6 together, 5-10 mm. long, much surpassed by the erect involucral bract; glumes acute, keeled, deciduous ; stamens 2-3; nut obtusely trigonous (plano-convex), obtuse at summit, finally black, strongly transversely wrinkled, usually with 5-6 short hypogynous bristles at base.-Isolepis supina, $\mathrm{R}$. Br.

Near Finke River, and therefore probably exists in our Far North.

8. S. nodosus, Rottb. Rootstock creeping; stems erect, subcompressed, 50-100 cm. high, stout and rigid by the sea, more slender inland; leaves reduced to sheathing bases; spikelets brown, clustered in a dense ovoid or globular head, the short stiff involucral bract continuing the stem; glumes obtuse; nut smooth, plano-convex, about $\frac{1}{2}$ as long as the glume.-Isolepis nodosa, $\mathrm{R}$. Br.

Sandhills near sea, and inland near water. Summer.

9. S. americanus, Pers. (1805). Rootstock creeping; stems rather stout, triquetrous ; leaves chiefly basal, plano-convex; spikelets brown, 6-10 mm. long, ovoid, usually 3-4 in a lateral cluster, surpassed by the erect involucral bract; glumes notched and mucronate ; style-branches 3 ; nut plano-convex, smooth; hypogynous bristles usually $6 .-S$. pungens, Vahl (1806).

In fresh and brackish water throughout the State. Oct.-Mar.

10. S. lacuster, L. Tall plant, with stout cylindrical stems; leaves almost reduced to sheathing bases; spikelets brown, 5-10 mm. long, numerous in an irregular umbel, which is shorter than the erect involucral bract; glumes keeled, mucronate, sometimes notched ; style-branches usually 2; nut plano-convex, smooth, shining; hypogynous bristles usually 6 , as long as or longer than the nut, with reflexed teeth.

In fresh or brackish water throughout the State. Oct.-Mar. 
11. S. littoralis, Schrad. Very near the preceding, but the umbel is looser, the oblong spikelets attain $15-20 \mathrm{~mm}$. when ripe, and the hypogynous bristles are not filiform, but are rather linear scales a little longer than the nut, channelled on the inner side and ciliate with flat hairs directed upwards.

Same localities and season.

12. S. maritimus, L. Rootstock creeping; stems tall, triquetrous, with long leaves ; spikelets golden-brown, ovoid, $10-18 \mathrm{~mm}$. long, clustered in a usually dense umbel; involucral bracts 3, exceeding the inflorescence; glumes notched or jagged, the keel ending in a spreading awn ; style-branches 3 : nut shining, trigonous ; bristles 6 .

In water near sea, and also inland. Sept.-Feb.

\section{LIPOCARPHA, R. Br.}

(Greek liparos, shining; karphos, chaff : alluding to the silvery glumes of L. argentea.)

1. L. microcephala (R. Br.), Kunth. Annual, with slender stems and narrow leaves; spikelets many-flowered, usually 3 together in a terminal cluster, ovoid, $\mathbf{3 - 4} \mathrm{mm}$. long; glumes imbricate all round the rhachilla, small, pointed; style-branches 2 ; nut compressed and enclosed in 2 hypogynous scales.

On the Murray in Victoria, and in the MacDonnell Ranges; therefore probably to be found in South Australia.

\section{CHORIZANDRA, R. Br.}

(Greek khōrizo, to separate ; anêr, andros, a male : referring to the separate male flowers.)

1. Ch. enodis, Nees. Stems slender but wiry, from a creeping rootstock; inner leaves stemlike, the outer reduced to sheathing bases; spikelets consisting of 1 terminal female flower surrounded by several male flowers of 1 stamen, each enclosed in a 3-toothed ciliate glume; spikelets numerous, compacted in a dense globular lateral reddish-black head, with a stiff erect involucral bract continuing the stem; style-branches 2 ; nut biconvex, ribbed.

Wet places in the southern districts and Eyre Penisula. Oct.-Dec.

\section{CLADIUM, P. Browne.}

(Greek kladion, a branchlet: alluding to the panicled inflorescence.)

Spikelets paniculate, with 1.3 bisexual flowers, but usually the lowest only fertile; glumes few, imbricate all round, the one bearing the fertile flower usually the largest, 1-3 outer ones empty; stamens and style-branches mostly 3; no hypogynous bristles. Perennials with a creeping rootstock. I'nited by Mueller and Tate with Gahnia.

A. Leaves almost reduced to the sheath.

B. Stems slender. stiff.

Spikelets numeruus .................. junceum 1.

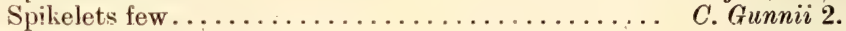

B. Stems rapillary, flexible ................ capillaceum 3 .

A. Leaves developed.

C. Panicle composed of derise umbels ............ C. Muriscus 4.

C. Panicle locse or narrow.

D. Leaves cylindrical.

E. Stems hollow, transversely partitioned ........ C. articulatum 5.

E. Sterns solid; panicle loose.

Leaves few, short .................. glomeratum 6 .

Leaves many, long................... filum 7 .

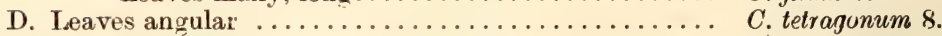

D. Leaves flattened ................... C. acutum 9.

1. C. junceum, R. Br. Stems slender but rigid, 30-60 cm. high : leaves almost reduced to sheaths on the stem and at base; spikelets few, reddish-brown in a spikelike panicle only $1.2 \mathrm{~cm}$. long; glumes acute, ciliate on keel, nut blackish, trigonous towards base.

Suuthern districts; Evre Peninsula; Flinders Range; South-East. Sumner.

2. C. Gunnii, Hook. f. Stems as in the preceding; leaves reduced to sheaths, or 1 or 2 with a stemlike blade; panicle narrow, $3.5 \mathrm{~cm}$. long, interrupted, with erect branches; spikelets few, rather distant, 5.6 mm. long, 1-flowered ; glumes acute ; nut trigonous, shining, with a cushion-like summit.

Mount Lofty Range. Recorded by Bentham, but does not appear to have been found since.

3. C. capillaceum (Benth.), C. B. Clarke. Stems capillary, leafless except for sheathing bases; spikelets narrow, acute, $3-4 \mathrm{~mm}$. long, 1-flowered, forming a slender panicle of 1-2 cm. ; nut white, globular, 3-ribbed, crowned by the thickened persistant base of the style as long as itself.-Elynanthus capillaceus, Benth.; Schoenus capillaris, F. v. M.

Kangaroo Island. 
4. C. Mariscus (L.), Pohl. Stems hollow, stout, $1.2 \mathrm{~m}$. high ; with long Hat tapering leaves, scabrous on keel and margins; panicle long, leafy, formed of distant pedunculate umbels; spikelets brown, numerous, with 2 bisexual flowers, only the lower one fertile ; glumes obtuse; stamens 2; nut ovoid-conical, shining.

Mount Lofty Range ; South-East. Dec.-Jan.

o. C. articulatum, R. Br. Stems (1-2 m.) and leaves hollow, with transverse partitions ; panicle long, drooping, interrupted; spikelets numerous, brown, 3-5-flowered, 1 flower fertile, but not always the lowest; glumes acute; nut trigonous, whitish, with a cushionlike sum?nit.

Mount Lofty Range; Flinders Range; South-East. Nov.-Jan.

6. C. glomeratum, R. Br. Stems rigid; leaves stern-like or short; panicle narrow, often with a flexuose rhachis ; spikelets brown, in ovoid erect clusters, with broad scarious sheathing bracts at base; flowers 3-5, 1 lower one fertile; glumes acuminate, ciliate ; nut trigonous, smooth, often reddish, crowned by the pubescent base of the style.

Mount Lofty Range ; South-East. Oct.-Jan.

7. C. filum (Labill.), R. Br. Sterns tall, leafy; leaves long, tapering into long subulate points, passing into the floral bracts; panicle long, narrow, each branch and spikelet subtended by a bract, the outer ones leatlike, the inner ones passing into the glumes; spikelets rale-brown, numerous and crowded; flowers 2 , the lower one fertile; glumes acute; stamens 3 ; nut narrow-oblong, trigonous, $5 \mathrm{~mm}$. long; smooth. Resembles Gahnia trifida externally.

Mount Lofty Range; Adelaide Plains near coast; South-East; Eyre Peninsula; Kangaroo Island. June-Nov.

8. C. tetragonum (Labill.), comb. nov. Stems and leaves compressed-angular or distinctly quadrangular; panicle oblong, reddish-brown, $5-10 \mathrm{~cm}$. long, interrupted towards basc; floral bracts short, the upper ones glume-like; spikelets numerous, 1-flowered ; glumes acute, ciliate; nut with a cushion-like summit.-C. tetraquetrum, Hook. f. (1860) ; Lepidosperma testragona, Labill. (1804).

Mount Lofty Range. Oct.-Dec.

9. C. acutum (Labill.), Poir. Stems $(15-30 \mathrm{~cm}$. high) and leaves flat with obtuse margins, rigid; panicle $1 \frac{1}{2}-8 \mathrm{~cm}$. long, when long interrupted from near the top, the branches erect and flexuose; the lowest floral bract with a short sheath and leaflike pungent blade; spikelets 1-flowered; glumes acute; nut dark and shining when ripe.-C. schoenoidus, R. Br. (1810); Schoenus acutus, Labill. (1804).

Mount Lotty Range; South-East; Eyre Peninsula. Nov.-Tan.

\section{GAHNIA, Forst.}

(After Henry Gahn, a Swedish botanist.)

Spikelets paniculate, with 1 bisexual flower and usually 1 male flower below it ; glumes imbricate all round, 3-5 outer ones empty, the flowering glumes thinner and smaller than the others; no hypogynous bristles; stamens 3.6 ; filaments lengthened. persistant; styles usually 3 ; nut obovoid. Perennials.

A. Gluines acute.

B. Tall plants.

Spikelets alruost black, distant ............ G. radula 1.

Spikelets brown, clustered ............ G. trifida 2 .

B. Plants about $30 \mathrm{~cm}$. high ; leaves pungent.

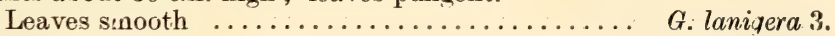

Leaves scabrous ................. G. deustu 4.

A. Gluines obtuse ; nuts red ............... pittacorum 5.

1. G. radula (R. Br.), Benth. Stems 50-100 cm. high; leaves inrolled, with long subulate points, scabrous downwards; panicle $12-35 \mathrm{~cm}$. long, black, with erect or erectspreading branches, the lower floral bracts like the leaves; spikelets numerous, not clustered, 2-flowered, only the upper one fertile; stamens 3 ; nut obovoid, trigonous, dark.

Mount Lofty Range (doubtful); South-East. Oct.-Jan.

2. G. trifida, Labill. Cutting-grass. Stems rigid, usually over $1 \mathrm{~m}$. high; leaves inrolled, with long subulate drooping points, very scabrous on the lower face; panicle erect, narrow, interrupted, $20-40 \mathrm{~cm}$. long; floral bracts leaflike; spikelets brown, densely clustered, usually 1 -flowered; glumes acuminate; stamens 4-5; nut ovoid, black, shining, bluntly trigonous, $2 \mathrm{~mm}$. long.

Mount Lofty Range; Kangaroo Island; South-East. Sept.-Dec.

3. G. lanigera (R. Br.), Benth. Stem slender, 20-30 cm. high ; leaves erect, subulate, smooth, pungent-pointed, the brown sheaths woolly at the orifice; panicle slender, narrow, 4.12 cm. long, often surpassed by the lowest of the leaflike floral bracts ; spikelets 
dark-brown, 2-flowered, only the upper one fertile; stamens 3 ; nut obovoid, obtusely trigonous, smooth, whitish.

Southern districts; Yorke and Eyre Peninsulas. Most of the year.

4. G. deusta (R. Br.), Benth. Resembles the preceding, but is a stouter plant $30-50 \mathrm{~cm}$. high; leaves with woolly orifices to the almost black sheaths and subulate blades which are scabrous downwards, espécially near the involute margins; panicle narrow, 20-30 $\mathrm{cm}$. long, with erect distant branches and several long, leaflike bracts ; spikelets becoming black, 2-flowered; glumes acuminate, the outer ones ciliate ; stamens 5-6 ; nut smooth, trigonous.

Southern districts, at least as far south as Coonalpyn; Yorke and Eyre Peninsulas. Aug.-Dec.

5. G. psittacorum, Labill. Stems stout, about $2 \mathrm{~m}$. high ; leaves inrolled, scabrous, with long subulate points; panicle compound, oblong, $40-60 \mathrm{~cm}$. long, the branches erect or drooping, the lower bracts leaflike; spikelets numerous, at first brown, finally black, 2-flowered; outer glumes obtuse and mucronate, the flowering ones very obtuse or notched; stamens 4 ; nut ovoid, trigonous, bright-red, 3-4 mm. long.

Mount Lofty Range; the Coorong. Dec.-Feb.

\section{CAUSTIS, R. Br.}

(Greek kaustos, burnt, scorched : from the appearance of the sheathing bases.)

1. C. pentandra, R. Br. Stems erect, from a creeping rootstock, the branches stiff, plano-convex; leaves reduced to black, closed, pointed sheaths ; spikelets brown, narrow, $12-15 \mathrm{~mm}$. long, erect, usually 2 from the same sheath, of which 1 is pedicellate; glumes stiff, acuminate, outer empty ones $4-5$, then a male flower, and above it a fertile flower with 5 stamens; style-branches 3 ; nut crowned with the larger persistant pubescent base of the style; no hypogynous bristles.

Square Waterhole (Mount Lofty Range); Kangaroo Island; South-East. Nov.-Jan.

\section{LEPIDOSPERMA, Labill.}

(Greek lepis, lepidos, a scale ; sperma, seed : alluding to the hypogynous scales surrounding the nut.)

Spikelets paniculate, with 1 fertile Hower and usually 1 or more male flowers below it; glumes few, imbricate all round the rhachilla, a narrow empty one above the fertile flower ; stamens usually 3 ; style 3 -fid, deciduous ; nut trigonous with a pale cushion-like summit ; hypogynous scales 6 , enlarged and thickened under the fruit; leaves basal. Perennials.

A. Stems hollow, biconvex, tall ; leaves equitant.

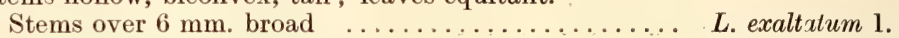

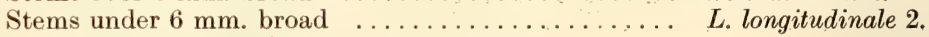

A. Stems solid, compressed, hard; leaves equitant.

B. Stems with sharp edges, not viscid.

C. Stems $8-20 \mathrm{~mm}$. broad ..................... Lladiatum 3 .

C. Stems $3-7 \mathrm{~mm}$. broad

Panicle short and dense .............. L. concavum 4 .

Panicle long and narrow $\ldots \ldots \ldots \ldots \ldots \ldots \ldots$ L. laterale 5.

C. Stems about $2 \mathrm{~mm}$. broad.

Upper bracts long and awned ........... L. congestum 6 .

Upper bracts glume-like ................. L. lineare 7.

B. Stems with rough viscid edges................ Liscidum 8.

A. Stems cylindrical, usually slender.

D. Panicle narrow, $3-7 \mathrm{~cm}$. long.

Leaves cylindrical .................. L. canescens 9.

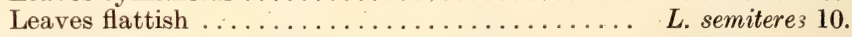

D. Panicle interrupted, spikelets clustered, black.

Panicle 8-10 cm. long; spikelets 4-6 mm. ..... L. striatum 11.

Panicle 2-3 cm. long; spikelets $10 \mathrm{~mm} . \quad \ldots \ldots \ldots$ L. carphoides 12.

1. L. exaltatum, R. Br. Stems 1-2 m. high, 6-7 mm. broad, biconvex with acute edges ; pith continuous; leaves similar; panicle $10-25 \mathrm{~cm}$. long, narrow, the lowest subtending bract $4-10 \mathrm{~cm}$. long; spikelets brown, 6-7 $\mathrm{mm}$. long, densely crowded on the erect paniclebranches, with 1-4 barren flowers besides the fertile one; scales under the nut united towards base, acuminate, the points quite glabrous.

In the South-East from Glenelg River westwards; Square Waterhole (Mount Lofty Range). Summer.

2. L. longitudinale, Labill. Not very satisfactorily distinguished from the preceding, except that the pith is interrupted, the stem usually rather narrower, the panicle looser and not so long.

Myponga (Mount Lofty Range). Summer. 
3. L. gladiatum, Labill. Sword Rush. Stems rigid, over $1 \mathrm{~m}$. high, 8-20 mm, broad, biconvex with sharp edges ; leaves similar but flatter; panicle dense, thick, or the lower branches spreading, $4-15 \mathrm{~cm}$. long; spikelets pale-brown, 6-8 $\mathrm{mm}$. long, with or without a barren flower below the fertile one; scales thick, with ciliate points.

On sandy coasts. Summer.

4. L. concavum, R. Br. Stems $20-50 \mathrm{~cm}$. high, flat, or slightly convex on one side, $3-5 \mathrm{~mm}$. broad ; leaves the same ; panicle narrow, dense, $3-8 \mathrm{~cm}$. long ; lowest bract $\frac{1}{2}$ as long, or sometimes as long as panicle, the upper bracts long-awned, glumes brown, acuminate; hypogynous scales broad, shortly pointed, ciliate at summit.

Southern districts. Summer.

5. L. laterale, R. Br. Stems 40-100 cm. high, 4-7 mm. broad, flat or somewhat concave ; panicle narrow, loose, $10-20 \mathrm{~cm}$. long, the spikelets distinct or rarely clustered, with 1 barren flower below the fertile one; glumes acuminate; lowest bract much shorter than panicle; scales with long ciliate points, sometimes as long as the shining nut.

Southern districts as far east as Lameroo ; South-East. Most of the year.

6. L. congestum, R. Br. Stems 10-20 cm. high, flat or biconvex, $2-3 \mathrm{~mm}$. broad ; leaves similar; panicle almost spikelike, $2 \frac{1}{2}-7 \mathrm{~cm}$. long, the spikelets clustered; subtending bracts all awned, pungent-pointed; spikelets about $4 \mathrm{~mm}$. long.

Eyre Peninsula. Perhaps only a form of L. concavum.

7. L. lineare, R. Br. Stems $20-60 \mathrm{~cm}$. high, $1 \frac{1}{2}-2 \frac{1}{2} \mathrm{~mm}$. broad, biconvex with acute edges ; leaves similar ; panicle narrow, $2-5 \mathrm{~cm}$. long, with almost erect branches ; lowest bract sometimes long; spikelets not numerous, $5-6 \mathrm{~mm}$. long, acute ; scales with ciliate points.

Mount Lofty Range. Summer.

8. L. viscidum, R. Br. Scarcely differs from $L$. concavum and $L$. laterale except in the rough brown viscid margins of the stems and leaves, and represents probably a form of those species in which these resinous exudations take place. The viscid line sometimes almost or quite disappears.

Southern districts. Summer.

9. L. canescens, Boeck. Stems slender, 25-60 cm. high, cylindrical, or slightly compressed and with blunt edges, $\frac{3}{4}-1 \frac{1}{4} \mathrm{~mm}$. broad ; inner leafblades cylindrical or biconvex and grooved on inner face; panicle narrow, $3-5 \mathrm{~cm}$. long, almost spikelike, or usually with erect branches near base; spikelets grey, distinct, often curved, 6-8 mm. long; seales with short ciliate points.

Southern districts; Kangaroo Island; South-East. Summer.

10. L. semiteres, F. v. M. Like the preceding, but the inner leafblades are flatter.

Mount Lofty Range. These 2 species are poorly distinguished and should probably be united.

11. L. striatum, R. Br. Stems about $1 \mathrm{~m}$. high, cylindrical, rigid, 2-4 mm. diam.; pith interrupted; panicle pyramidal, $8-10 \mathrm{~cm}$. long, with spreading-erect branches; floral bracts short, black, mucronate; spikelets $4-6 \mathrm{~mm}$. long, in dense clusters along the branches, 2-flowered, the lower flower barren; glumes brown, finely pubescent, the lower ones obtuse-mucronate; hypogynous scales broad, with a short ciliate point.

Mount Ilbillie, Everard Range. Differs from description in the number of barren flowers and may be an undescribed species.

12. L. carphoides, F. v. M. Stems filiform ( $\frac{3}{4} \mathrm{~mm}$. diam.), rigid, grooved on one side, about $40 \mathrm{~cm}$. high; leaves similar; panicle short, sometimes with a flexuose rhachis supporting th 3 clusters or partial spikes, which are often finally fanshaped; subtending bracts and glumes black, the former awned; spikelets with 1 barren and 1 fertile flower; scales broad, with points ciliolate at summit; nut pointed.

Southern districts; Eyre Peninsula; South-East. Summer.

\section{CAREX, L.}

(Latin name of some kind of rush.)

Flowers unisexual, in unisexual or androgynous spikelets, which are terminal, or also distant along the stem; glumes imbricate all round the rhachilla; ovary enclosed in a membranous sack or utricle, from which the 2 - or 3-fid style emerges; stamens usually 3 ; nut compressed or trigonous, enclosed in the persistant utricle. Perennials ("Sedges") with grass-like leaves and usually with creeping rootstock, inhabiting moist places.

A. Spikelets all androgynous; style-branches 2.

B. Spikelets few, in a terminal spike.

Spikelets $3-5 \ldots \ldots \ldots \ldots \ldots \ldots \ldots \ldots \ldots \ldots \ldots \ldots \ldots \ldots$. inversa 1.

Spikelets $6-12 \ldots \ldots \ldots \ldots \ldots \ldots \ldots \ldots \ldots \ldots \ldots \ldots \ldots$. chlorantha 2 .

B. Spikelets numerous, in a long narrow panicle.

Stems trigonous $\ldots \ldots \ldots \ldots \ldots \ldots \ldots \ldots \ldots \ldots$. appressa 3 .

Stems cylindrical $\ldots \ldots \ldots \ldots \ldots \ldots \ldots \ldots \ldots$ C. tereticaulis 4. 
A Spikelets few or many, the uppermost male, the lower chiefly female.

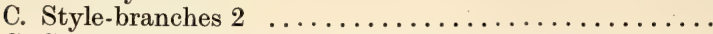

C. Style-branches $3 ; 1$ or more terminal spikelets male.

D. Spikelets erect, mostly sessile.

E. Utricle thick, glabrous.

Male spikelets usually 2 or more .........

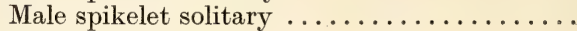

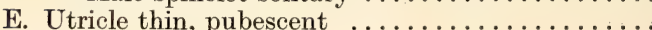

D. Spikelets long-stalked, drooping $\ldots \ldots \ldots \ldots \ldots$

\section{Gaudicha diana 5.}

\section{C. pumila 6 .}

C. Gunniana 8.

C. breviculmis 7 .

C. pseudocyperus 9 .

1. C. inversa, R. Br. Stems slender, $10-30 \mathrm{~cm}$. high ; spikelets ovoid, $6-10 \mathrm{~mm}$. long, sessile in a terminal cluster or one lower down; floral bracts leaflike, much longer than the inflorescence; male flowers usually at base of spikelet; utricle compressed, obovate, prominently nerved, ciliate on the edges, with a short bifid beak.

Southern districts; South-East. Sept.-Dec.

2. C. chlorantha, R. Br. Stems $15-60 \mathrm{~cm}$. high, smooth and glabrous; leaves shorter ; spikelets $6-12$, sessile in a dense terminal spike of $1 \frac{1}{2}-2 \frac{1}{2} \mathrm{~cm}$.; floral bracts glume-like but awned; male flowers at summit of spikelets; utricle compressed, with ciliate edges and a short bifid beak.

Lake Edward (South-East). Summer.

3. C. appressa, R. Br. Stems tall, triquetrous, scabrous on the edges towards summit ; leaves flat, with scabrous margins ; spikelets numerous erect, in a narrow spikelike panicle, $5-25 \mathrm{~cm}$. long; floral bracts usually inconspicuous; utricle as in the preceding.-C. paniculata, F. v. M. non L.

Southern districts; Flinders Range. Summer.

4. C. tereticaulis, F. v. M. Like the preceding, except that the stems are smooth, cylindrical, or obscurely trigonous.

Same districts and season.

5. C. Gaudichaudiana, Kunth. Stems slender, triquetrous with scabrous margins, sometimes short; leaves often longer, flat; spikelets $3-8$, cylindrical, $1 \frac{1}{2}-6 \mathrm{~cm}$. long, distant, sessile except the lowest, which may be shortly pedunculate, the upper 1 or 2 male, the others female, sometimes with a few males at summit; lower floral bracts long; glumes dark-brown, obtuse; utricle $2-3 \mathrm{~mm}$. long, flat, striate, with a short bifid beak; style-branches 2.-C. vulgaris, Fries, var. Gaudichaudiana, Boott; C. caespitosa, R. Br. non $\mathrm{L}$.

Southern districts; Flinders Range. Sept.-Dec.

6. C. pumila, Thunb. Stems triquetrous, 10-30 cm. high; leaves keeled in lower part, flat above; spikelets 4-7, the males terminal, 1-4, and close together; the remainder female, or with a few males at top, distant, the lowest shortly pedunculate; floral bracts long; female glumes reddish-brown, acute; utricle about $5 \mathrm{~mm}$. long, golden-brown, thick in texture, with a short 2-toothed beak; style-branches 3 .

Southern districts; South-East; Flinders Range. Summer.

Var. Bichenoviana, Kükenth. Stouter and taller than the type; male spikelets $6-20$, in a terminal cluster; female spikelets about 3 , the lowest pedunculate; utricle $4 \mathrm{~mm}$. long, often barren.-C. Bichenoviana, Boott.

Reedbeds; Grange Road. Summer.

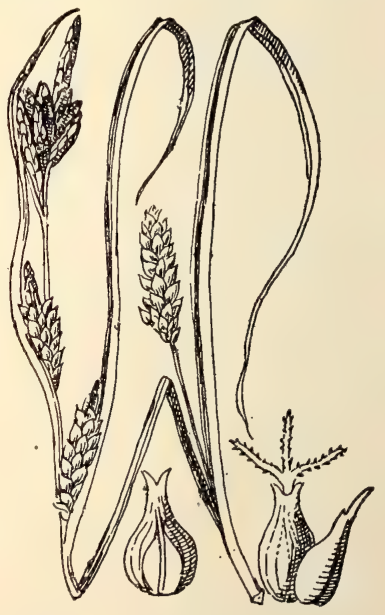

FIG. 24

Carex pumila, var. Bichenoviana.

7. C. breviculmis, R. Br. Stems $1-15 \mathrm{~cm}$. long; leaves and bracts narrower than in the preceding; spikelets 3-4, the terminal male; female glumes with a long mucro, equalling or exceeding the utricle, which is $4 \mathrm{~mm}$. long, including the short stipes and conical beak, and is minutely pubescent.

Mount Lofty Range; South-East. Summer.

8. C. Gunniana, Boott. In our specimens usually smaller than $C$. pumila ; spikelets 3-6, the male one terminal, solitary, the lowest female spikelet sometimes on a long peduncle; female glumes obtuse, golden, with a green keel and mucro ; utricle pale or greenish, with a slightly longer and more slender beak.

Southern districts and South-East. Summer. 
9. C. pseudocyperus, L. Stems triquetrous, $50 \mathrm{~cm}$. to $1 \mathrm{~m}$. high, scabrous on margins ; leaves flat; spikelets 3-6, pedunculate, drooping, 3-6 cm. long, all near together towards the top of the stem, the uppermost male, the others female; floral bracts leafy, much exceeding the inflorescence; glumes pointed; utricle spreading, narrow, shortly stalked, strongly nerved, tapering into a long 2 -cleft beak.

Mount Lofty Range; Kangaroo Island; River Murray; South-East. Summer.

\section{FAMILY 22.-LEMNACEAE.}

Flowers very rare, unisexual, the males consisting of 1 stamen and the females of 1 carpel, growing on the leaf and sometimes contained in a minute spathe; fruit a small utricle. Small floating plants, free in the water, each consisting of a leaflike lamina or shoot (here called "leaf") and propagating themselves by similar lateral growths from the edges of the leaves. Duckweed;.

The disk-like laminas are considered by some botanists to be modified stems, by others to be true leaves.

A. Leaves with roots growing from the undersurface.

Roots 2 or more to each leaf $\ldots \ldots \ldots \ldots \ldots \ldots$ SPIRodela 1.

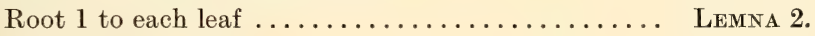

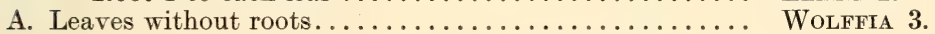

\section{SPIRODELA, Schleiden.}

1. S. oligorrhiza (Kurz), Hegelm. Leaves ovate, thin, 3-4 mm. long, with several lateral converging nerves, and each leaf with $2-5$ roots from the lower surface; flowers issuing from a slit in the edge of the leaf 1 female and 2 males within a minute spathe.Lemna oligorrhiza, Kurz.

Reedbeds, near Adelaide.

\section{LEMNA, L.}

(Greek name of a water-plant.)

Flowers as in Spirodela, but only 1 root to each leaf, and the nerves inconspicuous or none.

A. Leaves lanceolate or oblong $\ldots \ldots \ldots \ldots \ldots \ldots \ldots$. trisulca 1.

A. Leaves ovate or suborbicular.

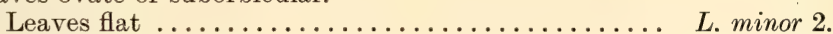

Leaves convex below................... L. gibba 3 .

1. L. trisulea L. Leaves oblong or lanceolate, thin, petiolate, 10-12 $\mathrm{mm}$. long with the petiole ; 3 or more united together, often dichotomously.

River Murray ; South-East.

2. L. minor, L. Leaves broadly ovate, opaque, flat, $2-4 \mathrm{~mm}$. long, separating when mature.

In still water in southern districts.

3. L. gibba, L. Leaves obovate, flattish above, convex and spongy below.

Mount Gambier.

3. WOLFFIA, Hork. et Schleid.

(After J. F. Wolff, German physician and botanist, 1778-1806.)

1. W. arrhiza (L.), Wimm. Very small floating plant; leaf about $1 \mathrm{~mm}$. diam., thick, very convex beneath, without roots; flowers rising on the surface of the leaf, without a spathe; stamen solitary with an almost sessile anther.

River Murray.

\section{FAMILY 23.-RESTIONACEAE.}

Flowers unisexual and mostly dioecious, or rarely bisexual, arranged in spikelets or panicles, each flower in the axil of a rigid glume; perianth of 6 or fewer glume-like segments, rarely none; male flowers of 3 stamens; anthers 1-celled; female flowers with a 1-3-celled ovary, and 1-3 slender styles or branches; ovule 1 in each cell, pendulous; fruit a capsule or nut; seed albuminous. Rush-like perennials, the leaves almost reduced to brown distichous sheathing bracts imbricate at the base of and distant along the stem, split on one side and not tubular, as in Cyperaceae.

A. Ovary 3-celled; flowers panicled $\ldots \ldots \ldots \ldots \ldots \ldots$ LEPYrodia 1.

A. Ovary 1-celled.

B. Styles or style-branches 3 .

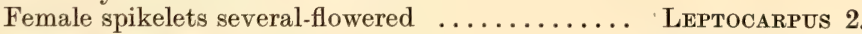

Female spikelets 1 -flowered $\ldots \ldots \ldots \ldots \ldots \ldots \ldots$ Hrpolanna 3.

B. Style undivided.

Female spikelets 1 -flowered $\ldots \ldots \ldots \ldots \ldots \ldots$ Loxocarya 4.

Female spikelets several-flowered ........... LePIdobolus 5 . 


\section{LEPYRODIA, R. Br.}

(Greek lepyròdes, furnished with bracts.)

1. L. Muelleri, Benth. Stems simple, erect, $40-60 \mathrm{~cm}$. high, from a creeping scaly rootstock; sheathing bracts appressed, with a short filiform blade, those under the inflorescence looser ; flowers monoecious, in compound distant pale-brown spikes, forming a narrow panicle; upper floral bracts and glumes acuminate or obtuse ; perianth-segments 6 , about $3 \mathrm{~mm}$. long, acute ; ovary 3 -angled, 3 -celled ; capsule opening at the angles.

Swamps at Tarpeena (South-East).

\section{LEPTOCARPUS, R. Br.}

(Greek leptos, thin ; karpos, fruit.)

Flowers dioecious; perianth-segments 6 or 5 ; stamens and style-branches 3 ; spikelets of both sexes several-flowered; ovary 1-celled; fruit angular, dehiscent.

Male spikelets $2-4 \mathrm{~mm}$. long; females erect, free....... L. tenax 1.

Male spikelets 5-12 mm. long; females in short clusters.... L. Brownii 2.

1. L. tenax, R. Br. Stems simple, $50 \mathrm{~cm}$. to $1 \mathrm{~m}$. high, with dark appressed sheathing bracts at intervals : male spikelets about $3 \mathrm{~mm}$. long, numerous in a loose panicle, reddishbrown; glumes obtuse ; perianth-segments hyaline, obtuse, $1 \mathrm{~mm}$. long ; female spikelets erect, about $10 \mathrm{~mm}$. long, sessile, in a dense erect panicle, the lowest branch often distant ; glumes acuminate; the 2 outer perianth-segments complicate and keeled, longer than the inner ones.

Mount Lofty Range; South-East. Summer.

2. L. Brownii, Hook. f. Stems as in the preceding, the sheathing bracts shorter ; male spikelets $5.12 \mathrm{~mm}$. long, shortly pedicellate, few, in a short spreading panicle; glumes acuminate; perianth-segments linear ; female spikelets of 3-6 flowers (but each flower looking like a 1-flowered spikelet), the spikelets clustered in a short panicle or head each flower with an acuminate glume and bracteole at base; outer perianth-segments glumelike, the inner smaller but thick.

Eyre Peninsula; South-East. Summer.

3. HYPOLAENA, R. Br.

(Greek hypo, below ; laina, a cloak : alluding to the bracteoles and empty glumes at the base of the spikelets.)

Flowers dioecious; perianth-segments 6 ; male spikelets several-flowered, female 1-flowered; stamens 3 ; style-branches $2-3$; ovary 1-celled; fruit an indehiscent nut.

Male spikelets solitary, sessile within sheathing floral bracts $H$. lateriflora 1.

Male spikelets pedicellate in a small panicle.......... H. fastigiata 2.

1. H. lateriflora (R. Br.), Benth. Stems slender, branched and flexuose; sheathing bracts and floral bracts with short subulate spreading blades and woolly at the orifice; spikelets sessile, solitary within the distant floral bracts; male flowers with 6 equal perianth-segments; female spikelets $4-6 \mathrm{~mm}$. long, with acuminate rigid glumes ; perianth-segments 4 or 6 , hyaline ; nut almost globular.-Calostrophus lateriflorus, F. v. M.

Mount Lofty Range. Summer.

2. H. fastigiata, R. Br. Stems with flexuose branches and dark sheathing bracts with an erect mucro; male spikelets $6-8 \mathrm{~mm}$. long, on slender white-tomentose pedicels, numerous in a loose terminal panicle ; 2 outer perianth-segments complicate and keeled, the next one flat and the 4 inner ones smaller; female spikelets $6-10 \mathrm{~mm}$. long, usually terminal and solitary; perianth-segments broadly ovate and resembling hypogynous scales round the nut.

Mount Lofty Range; Kangaroo Island; Flinders Range; Eyre Peninsula; Keith ; South-East. Summer.

\section{LOXOCARYA, R. Br.}

(Greek loxos, oblique ; karyon, a nut.)

1. L. fasciculata (R. Br.), Benth. Stems $10-20 \mathrm{~cm}$. high, glabrous or pubescent; sheathing bracts brown, broad and loose at summit, truncate-mucronate, almost all enclosing a dense cluster of angular barren often curved branches, $1 \cdot 2 \frac{1}{2} \mathrm{~cm}$. long; female spikelets sessile (male pedicellate?) in the cluster of branches, l-flowered, 4-5 mm. long; glumes 6-7, closely imbricate, emarginate-mucronate, ciliate, 4-8-nerved; style simple, the stigmatic portion rather longer than the base; perianth-segments none. Male spikelets not seen.

Warunda and Edilillie, E. P. Summer. This may prove to be a variety of, or a distinct species from the West Australian plant, which has long hairs on the stems and more slender barren branches. 


\section{LEPIDOBOLUS; Nees.}

(Greek lepis, lepidos, a scale ; bolos, throwing away : the sheathing bracts of the stems are very deciduous.)

1. L. drapetocoleus, F. v. M. Stems simple, rigid, but flexuose in upper part, with distant brown rings which are the remains of the sheathing bracts ; flowers dioecious, both male and female in many-flowered spikelets, which form terminal, globular heads, 5-7 mm. diam.; glumes brown, truncate-mucronate; perianth-segments 5 , the 2 outer concave, keeled, the 3 inner ones flat; style simple.

Southern districts ; South-East. Summer.

\section{FAMILY 24.-CENTROLEPIDACEAE.}

Flowers bi- or unisexual, surrounded by 1-3 capillary scales, or naked, arranged in terminal heads or spikes; stamen 1, with a 1-celled anther ; carpels 1 or more, when several they are superposed spirally in 2 rows, each with a slender style and 1 pendulous ovule ; pericarp membranous; seed albuminous. Small annuals, with filiform radical leaves, the sheaths open on one side.

Flowers in a depressed head, surrounded by bracts ...... TRITHURIA 1.

Flowers in a flat spike, with several distichous bracts .... BRIzULA 2.

Flowers in a short spike or head, within 2 alternate bracts.. Centrolepis 3.

\section{TRITHURIA, Hook. f.}

(Greek treis, three ; thyrion, a little door : alluding to the valves of the fruit.)

1. T. submersa, Hook. f. Dwarf glabrous annual, 1-3 cm. high, with filiform leaves and scapes, usually red; flowers several, without perianth, closely packed in a terminal head, with 4 lanceolate 1 -nerved bracts at base, 3-4 $\mathrm{mm}$. long; styles 3 , septate, often bifid; capsule triquetrous, opening from the base in 3 valves and 3 filiform nerves.

River Murray; Kangaroo Island; South-East. Summer.

\section{BRIZULA, Hieron.}

(Diminute of Briza, because the flower-spikes resemble the spikelets of that grass.)

Flowers monoecious, solitary within distichous bracts, forming a flat terminal spike, the males (each of a single stamen, with or without a scale) few at the base of the spike, the females (each of a single carpel) above; style undivided.

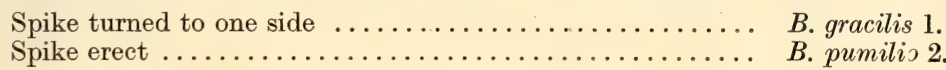

1. B. gracilis (Sond.), Hieron. Scapes filiform, 15-25 mm. high; spike ovate, 4-5 $\mathrm{mm}$. long, bent to one side; bracts about 8, hairy, the lowest much longer than the others and containing 1 or 2 male flowers, each within a hyaline scale; the female flowers without scales.-A phelia gracilis, Sond.

Beside creeks in southern districts and South-East. Sometimes grows with Cyperus tenellus, which it resembles. Summer.

2. B. pumilio (F. v. M.), Hieron. Like the preceding in size, but the bracts 8 -16, more pointed, with broader membranous margins; spike erect, the 2 lowest bracts spreading and often long, each containing 1-3 male flowers within scales; female flowers also within folded unequal-sided scales.

Southern districts and South-East. Summer.

\section{CENTROLEPIS, Labill.}

(Greek kentron, a spur ; lepis, a scale : the 2 floral bracts have long points.)

Flowers bisexual, each with 1-3 hyaline scales and forming a spike or head enclosed within 2 herbaceous floral bracts; stamen 1 ; carpels 3 or more, united in spiral rows, each with an undivided style, free or united towards base.

A. bracts much exceeding flowers.

Lower bract with a curved awn, 5-10 mm. long.... C. polygyna 1 .

Lower bract with a straight awn, $10-35 \mathrm{~mm}$. long... C C. aristata 2.

A. Bracts not twice as long as flowers.

Bracts glabrous .................... C. glabra 3 .

Bracts hairy $\ldots \ldots \ldots \ldots \ldots \ldots \ldots \ldots \ldots \ldots \ldots \ldots \ldots$ fascicularis 4.

A. Bracts scarcely exceeding flowers.

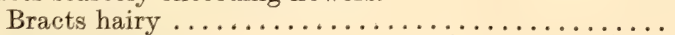

Bracts glabrous .....................

C. strigosa 5 .

C. Drummondii 6. 
1. C. polygyna (R. Br.), Hieron. Scapes $1-3 \mathrm{~cm}$. high; leaves much shorter; spike narrow; floral bracts brown, glabrou, rigid, the lower tapering into an awn, usually curved and often twice as long as the flower; flower solitary, with 1 scale; carpels 5-25; styles united near base.

Southern districts; Murray lands; Eyre Peninsula; SouthEast. Summer.

2. C. aristata (R. Br ), Roem. et Schult. Scapes $1-5 \mathrm{~cm}$. high, compressed; leaves often as long; spike broad; bracts brown, glabrous, both long-awned, the lower with a flat awn 10-35 mm. long, or 3-8 times as long as the bract and flowers ; flowers usually 10-15 in each bract, each with 2-3 scales; carpels 3-6.

South-East to Flinders Range; Eyre Peninsula. Summer.

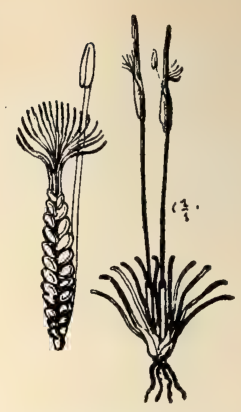

FIG 25.

Centrolepis polygyna.

3. C. glabra (F. v. M.), Hieron. Scapes and leaves filiform, reddish ; bracts glabrous erect, the lower one $3-4 \mathrm{~mm}$. long, including the short awn, the upper bract narrower, unawned; flowers in spike 4, without scales; carpels 7-8.

Murray River; Dismal Swamp, near Mount Gambier. Summer.

4. C. fascicularis, Labill. Scapes and leaves filiform, glabrous or sprinkled with hairs ; bracts ovate, erect, covered with long rigid hairs and terminating in glabrous awns about their own length; flowers 4-8 in each bract, each with a large scale and sometimes also a smaller one; carpels 2-4; styles almost free.

Mount Lofty Range; South-East. Summer.

5. C. strigosa (R. Br.), Roem. et Schult. Near the preceding, but the hairy floral bracts more spreading, with a point or awn usually about $\frac{1}{2}$ their length ; flowers 5 -10 in each bract, each with 3 unequal fringed scales; carpels 5-6.

South-East to Flinders Range; Eyre Peninsula. Summer.

6. C. Drummondii (Nees), Hieron. Scapes capillary, 3-5 cm. high ; leaves much shorter, minutely papillose; spike lanceolate or oblong; bracts glabrous but minutely papillose, about $4 \mathrm{~mm}$. long, shortly mucronate below the scarious summit, the upper one affixed $1 \mathrm{~mm}$. above the lower, the 2 not close together, as in most other species ; flowers $6-8$ in the spike, each with 1 or 2 unequal narrow scales; carpels 4-8; styles united in lower part.

Wooltana Station, near Lake Frome. Summer.

\section{FAMILY 25.-XYRIDACEAE}

Flowers bisexual, each solitary within a broad imbricate rigid bract, and the whole forming a terminal head; calyx irregular, of 1 broad thin segment enveloping the corolla, and 2 smaller lateral bract-like segments; corolla tubular below, 3-lobed above ; perfect stamens 3, attached to the base of the corolla-lobes and alternating with 3 staminodia; ovary superior, imperfectly 3 -celled, with numerous ovules; style 3 -branched ; placentas basal or parietal.

\section{XYRIS, L.}

(The Greek name for a species of Iris.)

1. X. opereulata, Labill. Perennial with slender scapes, $30-50 \mathrm{~cm}$. high ; leaves linear, with shining brown sheaths; flowerhead ovoid or globular, the bracts broad and almost black; the 2 lateral calyx-segments opaque, concave, with a ciliate keel; corollalobes conspicuous, yellow, ovate; capsule circumsciss near the summit; staminodia hair-tufted.

Myponga, Square Waterhole (Mount Lofty Range); Encounter Bay. Summer.

$X$ gracilis, $\mathrm{R} . \mathrm{Br}$, , which only differs from the above in being rather smaller, the lateral calyx-segments not keeled, and the placentas shorter, is recorded from the Glenelg River, Victoria, and may, therefore, be discovered in our State.

\section{FAMily 26. - ERIOCAULACEAE.}

Flowers very small, unisexual, crowded in a solitary terminal head on a simple scape ; each flower within an imbricate bract, the outer rows mostly female and th ; inner male; pərianth-segments 4-6, membranous ; stamens usually 6 ovary 2 -3-selled, with 1 pendulous ovule in each cell; capsule splitting loculicidally. 


\section{ERIOCAULON, L.}

(Greek erion, wool; kaulos, stem : alluding to the scapes of some species.)

1. E. submersum, Tate. Scapes $2-5 \mathrm{~cm}$. high; leaves lanceolate, in radical tufts, shorter ; heads small, globular, glabrous ; bracts ovoid, scarious, shining; female flowers of 2 concave keeled scarious outer segments and 4 flat oblong inner ones, 2-celled ovary and 2 -branched style; male flowers of 2 concave hyaline outer segments and 3 smaller concave inner ones higher up on the stalk which supports the 6 anthers.

In water at Publichouse Springs, between Lakes Blanche and Frome.

\section{FAMILY 27.-COMMELINACEAE.}

Flowers bisexual, axillary, enclosed in a complicate leafy bract or spathe ; sepals 3, imbricate; petals 3 , colored; stamens 6 , but some often barren ; ovary superior, 2-3. celled; ovules orthotropous, attached to axile placentas; style simple; fruit a capsule.

\section{COMMELINA (Plum.), L.}

(After Jan and Kaspar Commelin, Dutch botanists of the 17th and 18th centuries.)

1. C. ensifolia, R. Br. Weak, almost glabrous herb; leaves lanceolate, channelled, 4-10 cm. long, with stem-clasping base; spathe usually on a short stalk rising from the side of the stem opposite to the leaf, broad, oblique, leafy, closed at the base and containing a peduncle bearing 1-6 flowers on exserted pedicels ; 2 outer sepals larger than the 3 rd ; petals blue, about twice as long, 2 clawed, the 3rd almost sessile ; ovary 2-3-celled with 1 ovule in each cell; seeds smooth.

Near Oodnadatta. Spring.

\section{FAMILY 28.-JUNCACEAE.}

Flowers small, bisexual, with bracteoles at base and usually arranged in clusters; perianth glume-like persistant, of 6 lobes or segments in 2 rows, spreading when in flower; stamens 6 or 3 attached at the base of the perianth; anthers 2-celled; ovary superior, 1- or 3-celled, each cell with 1 or several ovules attached to parietal or basal placentas; style 3 -branched, capsule opening loculicidally by 3 valves; embryo small, straight, within the albumen; leaves narrow; mostly radical, sometimes reduced to sheathing bracts.

Leaves glabrous, cylindrical or channelled; capsule 3 celled, with numerous seeds .................. Juncus 1 .

Leaves hairy, flat; capsule with 1 cell containïng 3 seeds. : Luzula 2.

\section{JUNCUS, L.}

(Latin name for a rush.)

Stamens 6 or 3 ; ovary with 3 parietal placentas often meeting in the centre and dividing the ovary more or less perfectly into 3 cells; seeds minute, numerous, with a membranous testa often loose and transparent at the ends. Plants mostly growing near water and the perennial species usually with strong creeping rootstocks. Rushes.

A. Small annuals.

Stem-leaves absent; flowers in a terminal cluster ..

Stem-leaves present; flowers solitary or in small

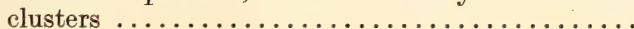

A. Perennials

\section{J. capitatus 1 .}

J. bufonius 2.

B. Leaves flat or broadly channeled.

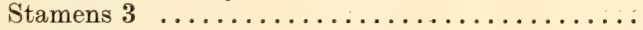

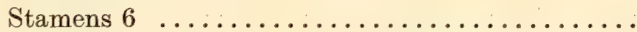

B. Leaves linear, channeled; flowers divaricate ........

B. Leaves cylindrical, stem-like.

C. Leaves and floral bract jointed, flaccid.

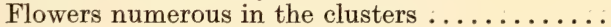

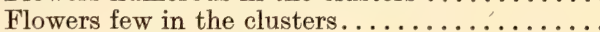

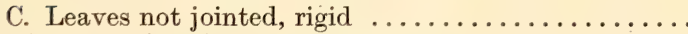

B. Leaves reduced to sheathing bracts; floral bract erect and continuing the stem.

D. Stems stout; stamens 6

D. Stems slender.

E. Panicle-branches almost straight.

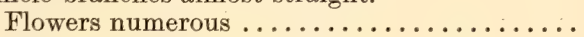

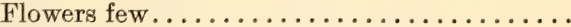

E. Panicle-branches curved like a sickle $\ldots \ldots \ldots \ldots$
J. planifolius 3 .

J. caespiticius 4.

J. plebeius 5.

J. holoschoenus 6.

J. lamprocarpus 7.

J. maritimus 8 .

J. pallidus 9 .

J. polyanthemus 10

$J$. pauciflorus 11 .

J. radula 12 . 
* 1. J. capitatus, Weig. Annual, with simple, filiform stems, $2-8 \mathrm{~cm}$. high ; leaves all radical, linear-channeled; flowers brown, 3-10 in a terminal cluster, usually solitary and surpassed by a leafy bract; outer perianth-segments with long curved points; stamens 3 ; capsule almost globular, shorter than perianth.

Southern districts; South-East; Eyre Peninsula. Sept.-Dec.-Almost cosmopolitan.

2. J. bufonius, L. Toad Rush. Annual, with branching stems, $3-25 \mathrm{~cm}$. high; leaves linear-channeled, radical and at the base of the branches; flowers pale-colored, solitary along the branches or 2-4 together; floral bracts linear-channeled, usually shorter than the infloresence; perianth 6-9 $\mathrm{mm}$. long, the segments lanceolate, unequal; capsule oblong, shorter than the 3 inner segments; stamens 6 or 3 .

Southern and Murray districts; Flinders Range ; Eyre Peninsula. Sept.-Dec.-Most temperate regions.

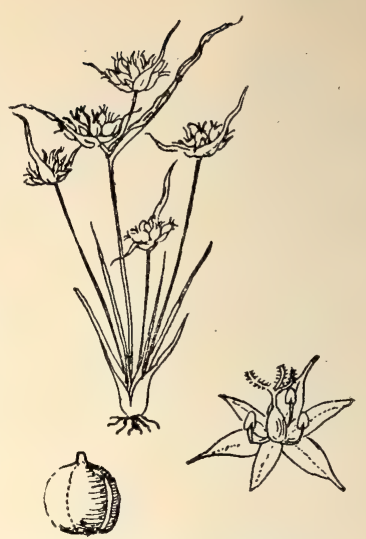

FIG 26. - Juncus capitatus.

3. J. planifolius, R. Br. Stems leafless, slender, $10-15 \mathrm{~cm}$. high; leaves radical, flat, or slightly channeled, grass-like, $3.8 \mathrm{~mm}$. broad; flowers brown in globular clusters, on the branches or in the forks of a terminal umbel-like infloresence, sometimes reduced to a single terminal cluster ; perianth-segments only $2 \mathrm{~mm}$. long; capsule ovoid, as long as the perianth; stamens 3 .

Southern districts and principally in the Mount Lofty Range ; Flinders Range ; SouthEast. Nov.-Feb.

4. J. caespiticius, E. Mey. Near the preceding, but the leaves more channeled, only about $2 \mathrm{~mm}$. broad, inflorescence denser, perianth $3 \mathrm{~mm}$. long and stamens 6 . The narrow floral bract is longer than the infloresence, whereas in $J$. planifolius it is usually shorter.

Mount Lofty Range; South-East. Nov.-Feb.

5. J. plebeius, R. Br. Resembles J. bufonius, but is perennial, 6-15 cm. high, the leaves linear-channeled, radical, and sometimes longer than the stem; flowers divaricate, 2-6 together in clusters, sessile or pedunculate towards the end of the stem, with a long leafy bract under the lowest cluster; stamens 6 ; capsule as long as the 3 inner perianthsegments.-J. homalocaulis, F. v. M.

Swamp near Kybybolite (South-East). Summer.

6. J. holoschoenus, R. Br. Stems almost cylindrical, usually $30-50 \mathrm{~cm}$. long, but sometimes dwarf; leaves mostly basal, hollow with pithy transverse partitions which make them appear jointed, especially when dried; flowers rather numerous in globular clusters, and forming a branching or compact panicle; floral bract leafy, jointed; perianth brownish, $4 \mathrm{~mm}$. long, equalling the narrow, triquetrous capsule ; stamens 6. -J. prismatocarpus, Benth. partly, not of R. Br.

Mount Lofty and Flinders Ranges; Murray lands; South-East. Summer.

7. J. lamprocarpus, Ehrh. Stems and leaves as in the preceding, but the clusters smaller, with only 2-8 flowers; perianth brownish, $3 \mathrm{~mm}$. long, the segments equal and the inner ones obtuse ; capsule abruptly mucronate, shining, and exceeding the perianth ; stamens 6

Mount Lofty Range. Summer.-Also in all the other continents.

8. J. maritimus, Lamk. var. australiensis, Buch. Stems from a creeping rootstock, about $1 \mathrm{~m}$. high, rigid, cylindrical ; leaves almost as long, stem-like, with pungent points ; flowers dark-brown in small clusters forming a compound somewhat lateral panicle, often surpassed by the erect rigid floral bract; segments $3 \mathrm{~mm}$. long. equalling the mucronate almost black shining capsule; stamens 6 .

Near fresh or brackish water in southern districts; South-East; Eyre Peninsula. Summer.

9. J. pallidus, R. Br. Pale Rush. Stems stout, $50 \mathrm{~cm}$. to $2 \mathrm{~m}$. high, $4-7 \mathrm{~mm}$. diam., with continuous pith; leaves reduced to brown basal bracts; flowers straw-colored, numerous, distinct in a rather loose or dense lateral panicle with a long erect bract; perianth $3-3 \frac{1}{2} \mathrm{~mm}$. long, the segments all acute, slightly surpassed by the ovoid capsule; stamens 6 .

Southern districts to Flinders Range; South-East. Summer.

10. J. polyanthemus, Buch. Variable, and in its larger forms approaching the preceding ; stems $20-80 \mathrm{~cm}$. high, 1-4 mm. diam., with interrupted pith; leaves reduced to basal 
bracts; flowers greenish, in a loose or dense lateral panicle, with an erect bract usually much exceeding it; perianth $2-3 \mathrm{~mm}$. long, about as long as the obtuse capsule, which is sometimes very small; stamens 3 , rarely 4 .

Southern districts to Flinders Range; Murray River; South-East. Summer.Searcely differs from the European $J$. effusus, L. (J.communis, E. Mey), except that the latter has continuous pith, and our plant should, perhaps, be considered an Australian variety.

11. J. pauciflorus, R. Br. Rather difficult to distinguish from slender specimens of the preceding, but the flowers are fewer and the capsule rather longer than the perianth ; stamens 6 or 3 ; pith interrupted or continuous.

Same localities and season.

12. J. radula, Buch. Stems in our specimens $10-20 \mathrm{~cm}$. high, slender, somewhat compressed; basal bracts and the whole plant straw-colored; panicle lateral, short but loose, the ultimate branches curved and bearing the flowers so as to resemble a scorpioid cyme ; stamens usually 3 ; segments equal, acute, $3 \mathrm{~mm}$. long, of the same length as the obtuse capsule.

Strzelecki Creek. This is the smooth variety, laevior, Buch. The type, which has the stem scabrous below the inflorescence, came from near the Murray.

\section{LUZULA, DC.}

(Neo-latin, from Italian luzziola, lucciola, the fire-fly : probably alluding to the shining and quivering character of the spikes.)

1. L. campestris, DC. Field Woodrush. Perennial with a swollen base, $10-30 \mathrm{~cm}$. high ; leaves grass-like, ciliate with long white hairs, mostly basal and 1 or 2 on the stem ; flowers brown, several in dense ovoid spikes on the unequal filiform branches of an umbel, and 1 or 2 spikes sessile; bracteoles at base of each flower scarious; perianth-segments 6 , equal, acuminate; stamens 6 ; capsule ovoid, 3 -valved, each of the 3 seeds with a hyaline appendage at base.

Southern districts, especially in the Mount Lofty Range; Eyre Peninsula; South East. Aug.-Nov.-Cosmopolitan.

\section{FAMILY 29.-LILIACEAE.}

Flowers regular, bisexual or rarely dioecious ; perianth colored or sometimes scarious, with 6 segments free or united towards the base, usually arranged in 2 rows ; stamens usually 6 , inserted at the base of the perianth ; anthers 2-celled, usually opening inwards ; ovary superior, 3 -celled, with 1 to numerous ovules in each cell, arranged on axile placentas, rarely 1-celled; styles 3 , or united into 1 ; fruit a berry or capsule, usually loculicidal. Perennial herbs, with a bulbous, tuberous, or fibrous rootstock.

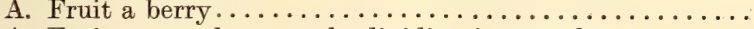
Dianella 1.

A. Fruit a capsule or rarely dividing into nutlets.

B. Style 3-branched.

C. Flowers bisexual, umbellate

C. Flowers unisexual.

Flowers few ; leaves flaccid, stem-clasping ....

Flowers numerous; leaves rigid .............

B. Style undivided, the terminal stigma entire or 3-lobed.

D. Perianth-segments twisted spirally after flowering.

E. Fruit a 3-valved capsule.

F. Petals fringed

F. Petals not fringed.

Flowers racemose $\ldots \ldots \ldots \ldots \ldots \ldots \ldots \ldots$

Flowers corymbose $\ldots \ldots \ldots \ldots \ldots \ldots \ldots \ldots$

E. Fruit separating into 1-3 indehiscent nutlets.

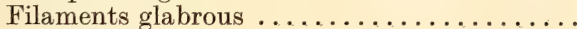

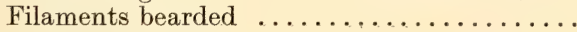

D. Perianth-segments not twisted after flowering.

G. Filaments bearded.

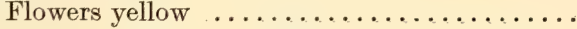

Flowers purple or whitish.............

G. Filaments glabrous.

H. Anthers with papillose appendages .........

H. Anthers without appendages.

I. Flowers whitish.

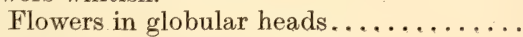

Flowers in a long dense spike .........

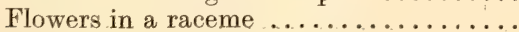

I. Flowers blue, solitary, terminal .........

BURCHARDIA 2.

Anguillaria 3.

LOMANDRA 4.

Thysanotus 5 .

Caesia 6.

Chamaescilla 7 .

CoRynotheca 8.

Tricoryne 9.

Bulbine 10.

Arthropodium 11.

Dichopogon 12.

Bartlingia 13.

Xanthorrhoea 14.

Asphodelus 15.

Calectasia 16. 
1. DIANELLA, Lamk,

(Diminutive of Diana, the goddess of hunting.)

Perianth blue, of 6 segments, each with 4-5 parallel nerves; stamens 6 ; filaments thickened near the anther; ovary 3 -celled, with several ovules in each cell ; style slender with a capitate stigma; fruit a globular or ovoid bluish berry; seeds black, shining. Perennials, with rigid stems and long distichous mostly basal leaves, with long sheaths.

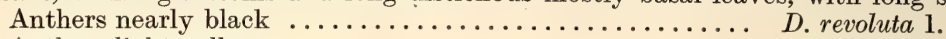

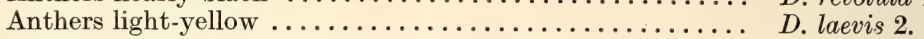

1. D. revoluta, R. Br. Leaves to $1 \mathrm{~m}$. long, the rigid blades with revolute margins covering the midrib, the sheaths closed at summit; panicle large and loose ; anthers almost black, and immediately below the anther a shorter broad yellow appendage which is considered to be the swollen summit of the filament, the slender part being usually geniculate.

Southern districts to Flinders Range; Eyre Peninsula; South-East. Often found near the sea. Oct.-Dec.

2. D. laevis, R. Br. Leaf-blades flat or scarcely recurved on the margins, the sheaths quite open; anthers light-yellow, much longer than the swollen orange summit of the filament.

Not so common as the preceding; Mount Lofty to Flinders Ranges. Oct.-Dec.

\section{BURCHARDIA, R. Br.}

(After J. H. Burchard, M.D., an English botanist.)

1. B. umbellata, R. Br. Stems erect, $15-50 \mathrm{~cm}$. high ; leaves stem-clasping, 1 or 2 at the base and 1 or 2 shorter ones on the stem; flowers several in a terminal umbel; perianth white, of 6 deciduous segments; stamens 6 , the filaments, gradually swollen below the anther; style cleft into 3 recurved lobes; capsule trigonous, opening septicidally in 3 valves.

Southern districts; Eyre Peninsula; SouthEast. Oct.-Dec.

\section{ANGUILLARIA, R. Br.}

(After Luigi Anguillara, 1512-70, Professor of Botany at Padua.)

1. A. dioica, R. Br. Stems simple, $5-20 \mathrm{~cm}$. high, rising from a bulbous rootstock; leaves $2-3$, with a broad stem-clasping base and tapering upwards; flowers more or less dioecious, but sometimes bisexual ; perianth-segments 6 , free, usually white, with a lilac gland, which is sometimes bifid, below the middle of the segment; ovary 3 -celled, with 3 distinct styles; capsule oblong, loculicidal, obtusely trigonous.-Wurmbea dioica, F. v. M.

All over the State. July-Sept.

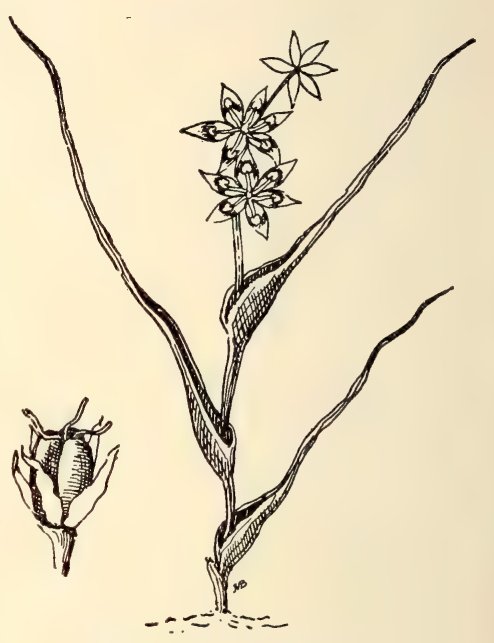

FIG. 27.-Anguillaria dioica.

\section{LOMANDRA, Labill.}

(Greek toma, margin ; aner, andros, a male : alluding to the circular margin of the anthers in some species.)

Flowers small, dioecious ; male perianth of 6 free or partly united segments ; stamens 6 ; female perianth of 6 segments; ovary 3 -celled, with 1 ovule in each cell; style 3 -cleft nearly to the base; fruit a subglobular capsule, opening loculicidally in 3 valves. Perennials, with narrow hard linear leaves, the sheathing bases of which are often split into silky filaments. Some species are popularly called "Iron-grass."

A. Male flowers clustered in a long whorled panicle.

B. Flowers sessile.

Bracts short, obtuse $\ldots \ldots \ldots \ldots \ldots \ldots \ldots \ldots$

Bracts with long acute points $\ldots \ldots \ldots \ldots \ldots \ldots \ldots$

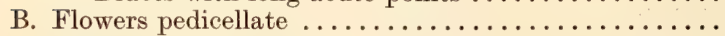

A. Male flowers scattered in short racemes or panicles.

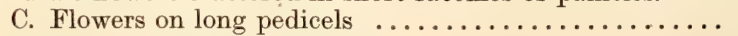

C. Flowers subsessile, minute.

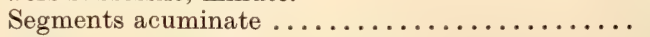

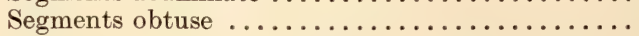

A. Male flowers in globular clusters on a short spike or panicle.

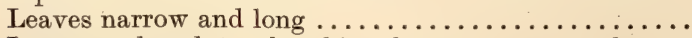

Leaves reduced to sheathing bases; pungent barren

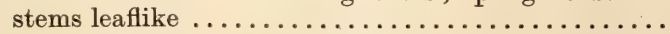

A. Male flowers in large woolly heads or cylindrical spikes

L. dura 1.

L. longifolia 2.

L. multiflora 3 .

\section{L. effusa 4.}

L. micrantha 5 .

L. filiformis 6 .

\section{L. glauca 7 .}

L. juncea 8.

L. leucocephala 9. 
1. L. dura (F. v. M.), Ewart. Leaves $30-50 \mathrm{~cm}$. long, $3-4 \mathrm{~mm}$. broad, rigid, glaucous ; flowers of both sexes clustered along the branches of a rigid whorled panicle ; bracts small; outer segments of male perianth scarious, free, the 3 inner yellow, fleshy, and united in lower part; 3 stamens attached to centre of inner lobes, the 3 others attached near the base of tube ; capsule globular, smooth, $5 \mathrm{~mm}$. diam.-Xerotes dura, F. v. M.

Southern districts to Flinders Range; Eyre Peninsula. Sept.-Nov.

2. L. longifolia, Labill. Leaves mostly radical, about $50 \mathrm{~cm}$. long, $4-8 \mathrm{~mm}$. broad, usually 2-toothed at summit; flowers in clusters along the whorled branches of a rather long panicle, the clusters subtended and usually much exceeded by long rigid lanceolate bracts; inner perianth-segments yellow, the outer rather stiff; stamens attached to base of segments; capsule hard, shining.-Xerotes longifolia, R. Br.

South-East. Oct.-Dec.

3. L. multiflora, (R. Br.), J. Britten. Leaves radical, long and rather narrow ; flowers clustered in a whorled pyramidal panicle; the males pedicellate, with short scarious bracts and bracteoles at base; perianth segments almost free; 3 stamens attached $\frac{1}{2}$ way up, the other 3 basal ; female flowers sessile ; capsule trigonous, finally black and transversely wrinkled.-Xerotes Brownii, F. v. M.

Mount Lofty Range. Oct.-Nov.

4. L. effusa (Lindl.), Ewart. Leaves $10-80 \mathrm{~cm}$. long, very rigid, about $2 \mathrm{~mm}$. broad, 2-toothed at summit; flowers scattered in an almost sessile panicle, the males on long pedicels with a conspicuous membranous bract at base of each; segments free, thin acute, 3-6 mm. long; female flowers on shorter pedicels or sessile ; capsule striate lengthwise.-Xerotes effusa, Lindl.

Southern districts; Murray lands; Eyre Peninsula. May-Sept.

5. L. micrantha (Endl.), Ewart. Leaves filiform, 10-30 cm. long ; flowers small, distinct, subsessile, in a short panicle or raceme, with bracts sometimes as long as the flower, perianth-segments $2-3 \mathrm{~mm}$. long, acuminate, the 3 inner ones greenish ; capsule depressedglobular, smooth.-Xerotes micrantha, Endl.

Mount Lofty Range; Eyre Peninsula. Oct.-Dec.

6. L. filiformis (Thunb.), J. Britten. Leaves up to $50 \mathrm{~cm}$. long, usually $2-3 \mathrm{~mm}$. broad, channeled, striate, glossy green, sometimes very narrow; flowers shortly pedicellate, in a narrow panicle or simple dense almost sessile raceme; bracts membranous, short; perianth-segments $2-3 \mathrm{~mm}$. long, obtuse, the 3 inner yellow, fleshy; capsule globular, smooth.-Xerotes Thunbergii, F. v. M.

Mount Lofty Range. Oct.-Dec.

7. L. glauca (R. Br.), Ewart. Leaves $5-50 \mathrm{~cm}$. long, narrow-linear, $1.2 \mathrm{~mm}$. broad; male flowers in globular clusters, forming a short interrupted spike or panicle; perianth funnel-shaped 2-4 mm. long, lobed above the middle, with 2 broad bracteoles at base; lobes yellow, tube purplish; stamens inserted on the lobes; female flowers in rather large solitary subsessile globular heads, the segments 4-5 $\mathrm{mm}$. long; capsule scarcely exceeding the persistant perianth, slightly marked with transverse wrinkles.

Murray lands ; South-East ; Eyre Peninsula ; north of Fowler's Bay. Aug.-Nov.

L. elongata (Benth.), Ewart, which scarcely differs from the preceding except that the female flowers are exceeded by their long-pointed bracteoles, is recorded by Bentham from Lake Bonney.

8. L. juncea (F. v. M.), Ewart. Rootstock creeping ; leaves reduced to brown sheathing bases, but the cylindrical rigid pungent-pointed barren stems have the appearance of leaves; flowering stems much shorter, with 3-5 globular heads of flowers enclosing the stem, and usually distant from each other; male flowers shortly pedicellate, each with 2 fringed bracteoles at base; perianth $5 \mathrm{~mm}$. long, funnel-shaped, the outer segments scarious, free, concave, about $\frac{1}{2}$ as long as the 3 inner, which are united in a tube in the lower part ; stamens inserted at the base of the 3 white obtuse lobes ; capsule acuminate, smooth.

Southern districts; Eyre Peninsula. Aug.-Oct.

9. L. leucocephala (R. Br.), Ewart. Leaves $30-80 \mathrm{~cm}$. long, usually $1 \frac{1}{2}-3 \mathrm{~mm}$. broad; flowers in dense globular or ovoid heads, $10-20 \mathrm{~mm}$. diam, enclosing the stem and distant, or united in a terminal cylindrical spike ; bracteoles deeply fringed and finally splitting into fibres which make the heads appear woolly; bracts sometimes exceeding the flowers ; male perianth pedicellate, 6-8 $\mathrm{mm}$. long, funnel-shaped, the outer segments concave, hyaline almost free, much shorter than the 3 inner ones, which are tubular towards the base; anthers as in the preceding; capsule hard, smooth, shining.-Xerotes leucocephala, R. $\mathrm{Br}$.

Sandy soil along the coast, and most inland parts of the State ; some specimens from Ooldea and farther north have leaves $4-5 \mathrm{~mm}$. broad, with resinous margins. Flowering most of the year. 


\section{THYSANOTUS, R. Br.}

(Greek thysanotos, fringed : alluding to the 3 inner perianth-segments.)

Perianth of 6 free segments, 3-nerved along centre, the 3 inner broader and more or less fringed on the edge, twisted spirally after flowering; stamens 6 , attached to the base of the segments and bent over to one side of the ovary; ovary 3-celled, with 2 superposed ovules in each cell; style filiform, undivided; capsule globular, 3-valved, with black carunculate seeds. Often called "Fringed violets." Perennials with radical leaves and usually blue or violet flowers.

A. Stems twining.

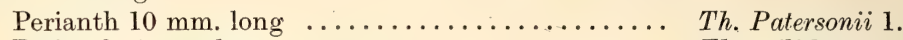

Perianth $5 \mathrm{~mm}$. long $\ldots \ldots \ldots \ldots \ldots \ldots \ldots$ Th. exiliflorus 2.

A. Stems erect.

B. Roots tuberous.

C. Bracts few.

Leaves few ; flowers large ............ Th. tuberosus 3 .

Leaves many; flowers small ........... Th. tenellus 4 .

C. Bracts many together, white, broad .......... Th. Baueri 5.

B. Roots without tubers; stem with forked branches ... Th. dichotomus 6.

1. Th. Patersonii, R. Br. Roots tuberous; radical leaves filiform, withering early, the others reduced to small bracts under the branches; stem wiry, twining, branched; flowers usually solitary at the ends of the short branches, violet, with 2 small bracts a little below the perianth, which is $8.10 \mathrm{~mm}$. long; eapsule rather shorter. Nov.

Southern districts to Flinders Range ; Pinnaroo; South-East ; Eyre Peninsula. Sept.-

2. Th. exiliflorus, F. V. M. Resembles the preceding, but the tubers longer and more cvlindrical; the flowers greenish, $4-5 \mathrm{~mm}$. long, with the 2 bracts at a greater distance ; perianth-segments scarcely twisted and the 3 inner ones very minutely fringed; capsule as long as perianth.

Innamincka; Ooldea. Aug.-Oct.

3. Th. tuberosus, R. Br. Roots tuberous; leaves few, linear, sometimes long; scape erect, rigid, $20-50 \mathrm{~cm}$. high, hearing a long, loose panicle, with long branches bearing 1 or 2 umbels of 1-3 flowers each; bracts lanceolate with 1 brown nerve; perianth 12-15 $\mathrm{mm}$. long: 3 of the anthers longer than the others and beaked.

Southern districts to Flinders Range; South-East. Oct.-Jan.

Th. exasperatus, F. v. M., which is stated by Bentham to differ from Th. tuberosus in nothing except that the stamens are nearly of equal length, is recorded from the Flinders Range. It is probably only a form or variety.

4. Th. tenellus, Endl. Roots tuberous; leaves numerous, persistant, linear, more than $\frac{1}{2}$ as long as the stem, with scarious sheaths; stem 15-20 cm. high; flowers 2-3 in pedunculate umbels, forming a short panicle; bracts small; perianth about $8 \mathrm{~mm}$. long, the inner segments narrow and minutely fringed; 3 anthers much longer than the others, but not beaked.

Alberga River (Far North). Aug.-Oct.

5. Th. Baueri, R. Br. Roots tuberous; leaves few, short, withering early; stem 20-30 cm. high, sometimes simple, with sessile umbels of flowers along the upper part, more often considerably branched, the bracts numerous, white and conspicuous ; perianth $8-10$ $\mathrm{mm}$. long; 3 anthers slightly longer than the others.

Southern districts to Far North; Fowler's Bay; South-East. Oct.-Dec.

6. Th. dichotomus (Labill.), R. Br. Roots fibrous, without tubers; leaves short, withering early; stem $30-60 \mathrm{~cm}$. high, rigid, with long, often dichotomous branches; umbels 1-3-flowered, with small usually 3 -nerved bracts at base of the pedicels; perianth $12.15 \mathrm{~mm}$. long; 3 anthers longer than the others and with curved beaks. Resembles Th. tuberosus.

Southern districts; Eyre Peninsula. Oct.-Jan.

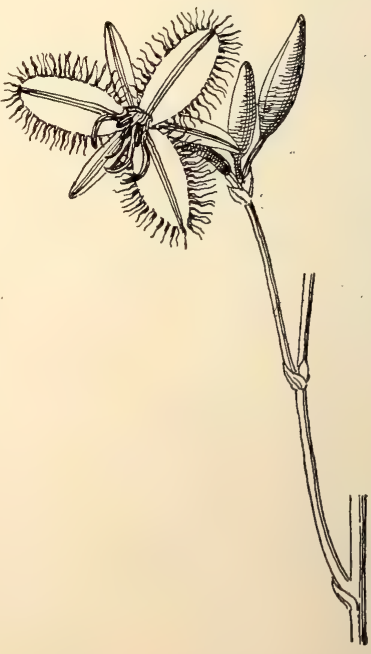

FIG. 28.-Thysanotus dichotomus. 
6. CAESIA, R. Br.

(After Federico Cesi, Italian naturalist, 1585-1630, who is said to have been the first. to discover the spores of ferns, and whose name was Latinized as Caesius.)

1. C. vittata, R. Br. Roots tuberous; leaves mostly basal, linear or lanceolate ; stem erect, 20-30 cm. long, simple or slightly branched; flowers blue, in small clusters along the upper $\frac{1}{2}$ of the stem on filiform pedicels about as long as they; perianth of 6 -nerved segments, spirally twisted after flowering ; stamens 6 ; filaments clavate ; style undivided; ovary 3-celled, with 2 ovules in each cell; capsule depressed, 3-lobed; seeds black, carunculate.

Southern districts; South-East. Sept.-Nov.

A specimen from Brighton, with the perianth about $6 \mathrm{~mm}$. long, but with leaves as broad as the others, may represent $C$. parviflora, $\mathrm{R}$. Br., if that be a distinct species.

7. CHAMAESCILLA, F. v. M.

(Greek khamai, dwarf; skilla, the squill or sea onion, a liliaceous plant of the Mediterranean region.)

1. Ch. corymbosa (R. Br.), F. v. M. Leaves radical, grass-like, channeled ; stem erect, $10-15 \mathrm{~cm}$. high, bearing near the summit a corymb of bright-blue flowers; perianthsegments 6, free, 3-nerved along the centre, $8-10 \mathrm{~mm}$. long, spirally twisted after flowering; stamens 6, with filiform filaments; ovary 3 -celled, with numerous ovules in each cell; capsule laterally compressed and acutely 3 -lobed, truncate at summit; seeds compressed, black, glossy.

Southern districts; Eyre Peninsula; South-East. Sept.-Nov.

\section{CORYNOTHECA, F. v. M.}

(Greek korynê, club; the ke, case : alluding to the shape of the fruit.)

1. C. micrantha (Lindl.), Macbride. Radical leaves short, withering early, those of the stem reduced to a few minute scales; stems rigid, filiform, repeatedly branching dichotomously; flowers small, distant along the branches; perianth $2 \mathrm{~mm}$. long; of 6 segments, twisted after flowering; ovary 3 -celled, with $1-2$ ovules in each cell; fruit an obovoid indehiscent nutlet, contracted into a stipes at base, with 1-2 black carunculate seeds.-C. dichotoma, F. v. M.

Far North-West.

C. lateriflora, F. v. M., with longer leaf-scales and flowers 3-4 mm. long, occurs in Western New South Wales, and may be found in our North-East.

\section{TRICORYNE, R. Br.}

(Greek treis, three ; koryne, , club : referring to the fruit.)

1. T. elatior, R. Br. Stems $10-50 \mathrm{~cm}$. high, stiff, branched; radical leaves grasslike, those of the stem shorter or reduced to bracts; flowers yellow, few in terminal umbels; perianth of 6 free segments, twisted after flowering, about $8 \mathrm{~mm}$. long; stamens 6 , the filaments bearded about the middle; ovary 3 -lobed and 3 -celled, with 2 ovules in each cell; style undivided; fruit divided to the base into 3 (or fewer by abortion) 1 -seeded nutlets; seeds black.

Southern districts to Flinders Range; Eyre Peninsula; South-East. Oct.-Feb.

\section{BULBINE, L.}

(Latin name for some kind of bulbous plant.)

Perianth-segments 6, free or almost so, 1-nerved, twisted after flowering ; stamens 6 , 3 or all of the filaments bearded above the middle; ovary 3 -celled, with several ovules in each cell ; style with a capitate stigma ; capsule opening loculicidally in 3 valves; seeds angular, blackish. Perennial herbs, with succulent, radical leaves and racemes of yellow flowers.

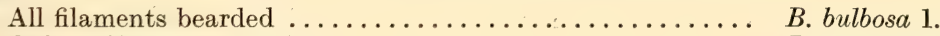

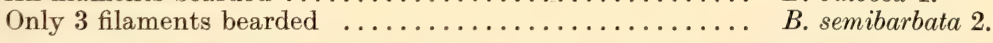

1. B. bulbosa (R. Br.), Haw. Roots thickened into a bulb-shaped tuber; leaves broadlinear, channeled; stems (or scapes) simple, erect, 20-50 cm. high; pedicels erect, lengthening after flowering, each with a scarious bract at base; perianth-segments 10-15 mm. long; filaments equal, all with a circle of clavate hairs below the anther.

Southern districts to Flinders Range; Murray lands; Eyre Peninsula; South-East. Sept.-Oct.

2. B. semibarbata ( $\mathrm{R}$. Br.), Haw. Resembles the preceding, but the perianth is smaller (about $6 \mathrm{~mm}$. long); the 3 filaments opposite the outer segments short and glabrous; the 3 opposite the inner segments longer and bearded; seeds usually reticulate-grooved.

Same localities and also the drier northern and western regions. Aug.-Oct. 


\section{ARTHROPODIUM, R. Br.}

(Greek arthron, a joint ; podion, a little foot : alluding to the jointed pedicels.)

Perianth of 6 free segments, not twisted after flowering, 3-nerved along the centre, the inner ones broader, undulate on the edge and sometimes shortly fringed; stamens 6 , the filaments densely bearded with clavate hairs in the upper part; anthers oblong; ovary 3 -celled, with several ovules in each cell ; capsule 3 -valved ; seeds black, angular; leaves basal, grass-like; flowers in loose racemes on pedicels articulate above the middle.

Flowers $2-3$ in the cluster $\ldots \ldots \ldots \ldots \ldots \ldots \ldots \ldots \ldots \ldots$. paniculatum 1.

Flowers usually solitary $\ldots \ldots \ldots \ldots \ldots \ldots \ldots \ldots \ldots \ldots \ldots$ A. minus 2.

1. A. paniculatum (Andr.), R. Br. Roots tuberous; stem erect, usually branched, $20-50 \mathrm{~cm}$. high ; flowers white or purplish, 2-3 together on filiform pedicels, with a scarious bract at base ; perianth-segments $6-7 \mathrm{~mm}$. long; anther as long as the bearded part of the filament and shorter than the whole filament.

South-East. Oct-Nov.

2. A. minus, R. Br. A smaller plant, 6-20 cm. high; flowers smaller and almost always solitary; the hairy part of the filament continued downwards in 2 short lobes which reach almost to the base of the filament.

Southern districts as far as Bordertown; Eyre Peninsula to Fowler's Bay. Oct.-Nov.

\section{DICHOPOGON, Kunth.}

(Greek dikhos, double; pōgōn, a beard : the anthers have 2 beardlike appendages.)

Similar to Arthropodium, except that each anther has 2 small papillose appendages at base, the appendages being also slightly attached to the summit of the filament, which is otherwise glabrous.

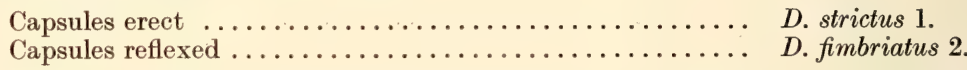

1. D. strictus (R. Br.), J. G. Bak. Stem stiff, $20-60 \mathrm{~cm}$. high, usually branched at base; flowers purple, scented, almost always solitary, in a long raceme; pedicels lengthening and spreading-erect under the erect globular capsule; perianth-segments $10-12 \mathrm{~mm}$. long; anthers dark-purple, with a short yellow appendage hanging from the base of each cell. - Arthropodium strictum, R. Br.

Southern districts to Flinders Range; South-East. Sept.-Dec.

2. D. fimbriatus (R. Br.), comb. nov. Near the preceding, but the flowers are usually in clusters of 2 to 4 ; pedicels and capsules turned downwards. - D. Sieberianus, Kunth ; Arthropodium fimbriatum, R. Br.

Southern districts. Sept.-Dec. Both these species grew formerly on the park lands of Adelaide, but are almost extinct there now.

\section{BARTLINGIA, F. v. M.}

(After F. G. Bartling, a German botanist (1798-1875). Laxmannia, R. Br. (1810), not of Forst. (1776).)

1. B. sessiliflora (Dene), F. v. M. Small perennial, with wiry slender usually branched stems, $3-8 \mathrm{~cm}$. high ; leaves subulate, $1-3 \mathrm{~cm}$. long, mostly in tufts, with scarious sheaths ciliate or woolly on the margins; flowers few, sessile in axillary heads, which are subsessile or on short recurved peduncles and surrounded by an involucre of scarious bracts, the inner bracts white and woolly at base; perianth-segments $6,4 \mathrm{~mm}$. long, the 3 inner white and rather longer than the outer ones; ovary 3 -celled, with $2-4$ ovules in each cell; capsule globular, enclosed in the persistant perianth ; seeds black, granular.-Laxmannia sessiliflora, Dcne.

Southern districts; South-East. Sept.-Nov.

\section{XANTHORRHOEA, Sm.}

(Greek xanthos, yellow ; rheo, to flow : alluding to the resin ("gum ") that flows from the stem.)

Perianth persistant, of 6 free segments, the 3 outer scarious below, green towards summit, concave, the 3 inner ones white, with short rounded laminae ; stamens 6 , usually exserted; ovary 3-celled, with few ovules in each cell, tapering into an undivided style; capsule hard, shining, 3-valved, protruding from the spike; seeds black, flat. Erect perennials, with a thick, woody stem or trunk, conspicuous or not rising above the ground; leaves long, rigid, brittle, pungent-pointed, in a dense tuft at the top of the stem ; scape or peduncle solitary, erect, simple, bearing a dense cylindrical spike of many flowers, each flower surrounded by numerous bracts and bracteoles. Grass-tree, yacca, blackboy.

A purely Australian genus of slow-growing long-lived plants. The stem, marked on the outside by the bases of the fallen leaves, doubtless lengthens with age, but in some species it is usually wanting, or very short. Bush fires appear to stimulate the subsequent 
flowering, and also to lead to branching of the stem in such species as $X$. quadrangulata and $X$. Tateana. The existence of some species is threatened by the fact that it is necessary to destroy the stem in order to obtain the commercially valuable resin.

A. Leaves $2 \mathrm{~mm}$. broad, quadrangular ............ quadrangulata 1 .

A. Leaves $3-10 \mathrm{~mm}$. broad, flattish or triquetrous.

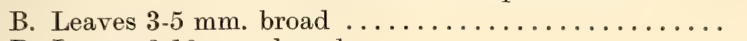

B. Leaves $8-10 \mathrm{~mm}$. broad.

Stem absent or short $\ldots \ldots \ldots \ldots \ldots \ldots \ldots \ldots$. semiplana 3 .

Stem 1-4 m. high .............. Tateana 4.

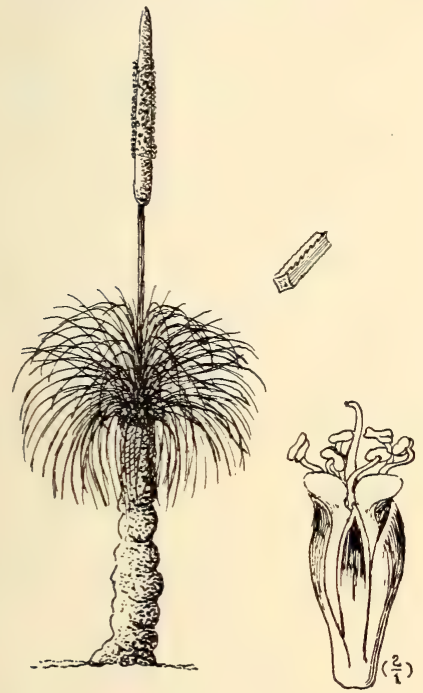

1. X. quadrangulata, F. v. M. Stem of old plants $1 \frac{1}{2}-3 \mathrm{~m}$. high, rarely (in some northern specimens) very short ; leaves $\frac{1}{2}-1 \mathrm{~m}$. long, $2 \mathrm{~mm}$. broad, quadrangular, or sometimes almost rhomboid in transverse section; scape $75 \mathrm{~cm}$. to $1 \mathrm{~m}$. long, $2 \frac{1}{2} \mathrm{~cm}$. diam.; spike equalling or rather longer than the scape, 3-6 cm. diam.; perianth-segments about $10 \mathrm{~mm}$. long ; capsule sharply acuminate.

Mount Lofty Range; northern agricultural areas ; Flinders Range. Feb.-Apl.

2. X. australis, R. Br. Usually stemless, but sometimes with a stem $20 \mathrm{~cm}$. to $1 \mathrm{~m}$. high; leaves flat on one side or angular on both sides, 3-5 mm. broad, $50-80 \mathrm{~cm}$. long; spike $40 \mathrm{~cm}$. to $1 \frac{1}{2} \mathrm{~m}$. long, $1-2 \mathrm{~cm}$. diam., usually but not always longer than the spike, which varies from $30 \mathrm{~cm}$. to $1.25 \mathrm{~m}$. in length, $3-5$ cm. diam. ; outer perianth-segments and bracts acuminate ; stamens twice as long as the perianth ; capsule rather obtuse.

In the South-East; near Naracoorte, Millicent, Penola, Glencoe. Mar.-Apl.

FIG. 29 - Xanthorrhoea quadrangulata.

3. X. semiplana, F. v. M. Stemless or with a very short stem; leaves 1-2 m. long, 8-10 $\mathrm{mm}$. broad, flat on one side with a raised midrib, angular on the other, so as to be subtriquetrous in section; scape and spike usually about the same length, about 1-3 m. long; scape $3.4 \mathrm{~cm}$., and the spike $5-6 \mathrm{~cm}$. diam.; capsule sharply acuminate.

Mount Lofty Range. Summer, and sometimes in winter.

4. X. Tateana, F. v. M. Stem 1-4 m. high, often branched; leaves as in the preceding, but sometimes slightly angular on both sides; spike stout, as in the preceding, 2-4 $\mathrm{m}$. long and usually somewhat longer than the scape,

Kangaroo Island, producing much valuable resin; also perhaps at Encounter Bay and Marble Range, E.P., but on the mainland this species tends to run into $X$. semiplana, to which it is closely related.

\section{ASPHODELUS, L.}

(Greek asphodelos, some liliaceous plant.)

* 1. A. fistulosus, L. Wild Onion. Stem and leaves hollow, the latter radical and cylindrical; flowers white, in long racemes ; perianth of 6 spreading segments ; filaments papillose near base; stigma 3-lobed; capsule globular, wrinkled transversely, with 1-2 black, triangular seeds in each of the 3 cells.

A bad weed in the settled districts. July-Sept.-Mediterranean region.

\section{CALECTASIA, R. Br.}

(Greek kalos, beautiful ; ektasis, development : alluding to the blue spreading perianth-lobes.)

1. C. cyanea R. Br. Blue Tinsel Lily. Stems shortly branched and covered with pubescent leaf-sheaths; leaves short, subulate, crowded; flowers blue, solitary at the end of the branches; perianth persistant, consisting of a tube 7.8 mm. long, and 6 spreading, rigid, lanceolate lobes; stamens 6 , inserted at the base of the lobes and with erect linear anthers; ovary 1-celled, with 3 erect ovules; style filiform.

Near Robe, and probably elsewhere in the South-East, but apparently rare. 


\section{FAMILY 30.-AMARYLLIDACEAE.}

Differs from Litiaceae chiefly in the ovary, which is inferior; anthers opening inwards and usually versatile; capsule loculicidal. Perennial herbs, with mostly radical leaves.

Flowers solitary, tubeless ...................... Hypoxis 1 .

Flowers in a terminal umbel, with tubes.

Flowers large, without corona ............... Crinum 2.

Flowers small, the filaments united in a corona ...... Calostemma 3.

\section{HYPOXIS, L}

(Greek hypoxys, somewhat acid, but said to have been applied by Linnaeus in the sense of " acute beneath," because the capsule is contracted at the base.)

Perianth persistant, divided to the inferior ovary into 6 spreading segments ; stamens 6 ; ovary 3 -celled, with many ovules in each cell ; style short, with 3 erect linear stigmas. Small herbs with radical leaves and bulbous rootstocks covered by fibres. The segments and stamens are sometimes 4 , and the cells and stigmas 2. Star-grass.

Stamens subequal; bract 1 large $\ldots \ldots \ldots \ldots \ldots \ldots \ldots \ldots$ H. glabella 1.

Stamens unequal; bracts 2, small ............... H. pusilla 2 .

1. H. glabella, R. Br. Glabrous herb ; leaves linear, sometimes longer than the scape, which is $6-25 \mathrm{~cm}$. long, with a long sheathing bract about the middle ; flowers terminal and solitary; perianth-segments $10-18 \mathrm{~mm}$. long, green below and bright-yellow above; capsule ovoid.

Southern districts; South-East. Aug.-Oct.

2. H. pusilla, Hook. f. Like the preceding, but not so tall, and the flowers smaller; bracts 2 , bristle-like, and the scapes often forked and bearing 2 flowers ; 3 stamens usually shorter than the others.

Southern districts; Murray lands; Eyre Peninsula. Aug.-Dec. Our form has not the very small flowers or the globular capsule of the eastern type.

\section{CRINUM, L.}

(Greek krinon, a lily.)

1. C. pedunculatum, R. Br. Murray Lily. Leaves long, radical, flat; scape about $50 \mathrm{~cm}$. high ; flowers white, fragrant, 5-15 in a terminal umbel, on pedicels of 2-4 cm. long, surrounded by a few large membranous bracts; perianth deciduous, of 6 lanceolate spreading lobes, $5-7 \mathrm{~cm}$. long, with a slender tube of about the same length ; stamens 6 , affixed at the base of the lobes; ovary 3 -celled, with several ovules in each cell; style long, filiform ; capsule ovoid, shortly beaked.-C. flaccidum, Herb.

Near River Murray; Flinders Range; Far North. Dec.-Apl.

\section{CALOSTEMMA, R. Br.}

(Greek kalos, beautiful; stemma, crown: alluding to the inner crown (corona) of the perianth.)

Perianth deciduous, with a short slender tube and a funnel-shaped deeply 6-lobed limb ; stamens 6 , inserted at the summit of the tube, the filaments winged and the wings united so as to form a tubular toothed corona; ovary 1-celled, with 2-3 ovules; style filiform ; fruit globular, succulent, usually 1 -seeded. Bulbous herbs, with radical leaves ; flowers in an umbel surrounded by 2 or 3 membranous bracts.

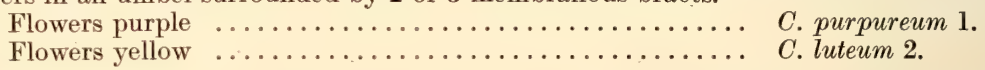

1. C. purpureum, R. Br. Leaves linear, developing to some length after the flowering; scape slender, $20-50 \mathrm{~cm}$. high ; flowers numerous in the umbel, usually purple, sometimes pink, on rather long pedicels, the whole perianth $15-18 \mathrm{~mm}$. long, of which the tube occupies rather less than half.

Southern districts to Flinders Range. Jan.-Apl.

2. C. luteum, Sims. Scarcely differs from the preceding, except that the flowers are yellow and rather larger.

Northern part of Flinders Range to Oodnadatta and Cooper's Creek. Jan.-Apl.

\section{FAMILY 31.-IRIDACEAE.}

This family has the inferior ovary and the 6 petal-like segments of Amaryllidaceae, but the stamens are only 3 , opposite the outer perianth-segments, and the cells of the erect anthers open outwards; style 1, with 3 branches, sometimes broad and petal-like; ovary 3 -celled with several or numerous anatropous ovules in each cell. Perennial herbs, with leaves either radical or arranged in 2 rows and equitant; flowers within a spathe consisting of 2 bracts or valves. 
In addition to the well established aliens described here, there are several other species, belonging mostly to South African genera (Watsonia, Antholyza, Gladiolus, Sparaxis, Babiana, \&c.) which have escaped from gardens, but are as yet too localised to be included in a national flora. They are dealt with in the "Naturalised Flora of South Australia."

A. Inner perianth-segments shorter or narrower than the outer.

Style-branches rounded, spreading ........... Patersonia 1.

Style-branches ending in an erect bifid wing ........... Moraea 2.

A. Perianth-segments all equal and spreading.

B. Flowers solitary in spathe; leaves narrow-linear..... Romulea 3.

B. Flowers 2 or more in each spathe; leaves broad-linear. Spathes ovoid-oblong, obtuse ............. Orthrosanthus 4. Spathes cylindrical, acuminate $\ldots \ldots \ldots \ldots \ldots \ldots$ Homeria 5.

\section{PATERSONIA, R. Br.}

(After Wm. Paterson, died 1810, an early botanical collector in Australia, and Lieut.Governor of New South Wales, 1800-1810.)

Perianth with a filiform tube and 3 outer broad and spreading lobes, the 3 inner very small and erect ; filaments united in a tube almost to the top; style filiform, with 3 broad spreading or reflexed stigmatic lobes; capsule opening loculicidally in 3 valves. Perennial herbs, with equitant radical leaves and short rootstock ; flowers blue, few within a terminal spathe of 2 rigid bracts, each flower subtended by a scarious bract.

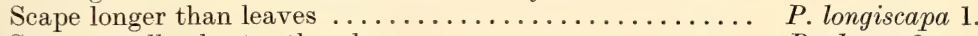

Scape usually shorter than leaves ............. P. glauca 2.

1. P. longiscapa, Sweet. Leaves broad-linear, erect, rigid, glabrous; scape longer; spathe brown, about $4 \mathrm{~cm}$. long and almost as long as the perianth-tube; perianth-lobes $2-2 \frac{1}{2} \mathrm{~cm}$. long.

Mount Lofty Range; South-East. Oct.-Jan.

2. P. glauca, R. Br. Near the preceding, but the scape usually much shorter than the leaves, the perianth-lobes shorter, and the stigmatic lobes ciliate.

Mount Compass (Mount Lofty Range); Kangaroo Island ; South-East. Nov.-Feb.

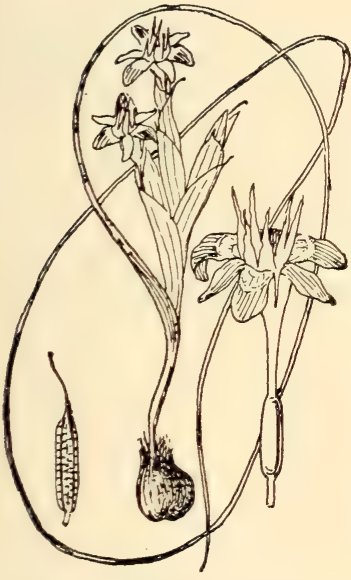

FIG. 30.-Moraea xerospatha.

\section{MORAEA, L.}

(After Robert Moore, an English botanist of the 18th century.)

*1. M. xerospatha, MacOwan var. monophylla, n. var. Dwarf plant rising from a small corm covered with fibres; leaf 1, radical, spreading, narrow-linear, tough, $25-70 \mathrm{~cm}$; long; stem short, bearing 3-5 hyaline nerved spathes. each spathe containing 4-6 flowers like those of a minute Iris; perianth lilac, blotched with orange and purple, the segments $15-18 \mathrm{~mm}$. long, spreading, subequal in length, but the inner ones much narrower; filaments more or less united in a tube; style-branches terminating in erect bifid petaloid lobes; ovary cylindrical, tapering into a beak $7.8 \mathrm{~mm}$. long, which resembles a perianthtube and remains persistant on the membranous capsule.

Southern districts and especially common near Adelaide. Sept.-Nov. Differs in having constantly 1 leaf, whereas the type, which grows near Capetown, has usually 3-4 leaves.

\section{ROMULEA, Maratti.}

(After Romulus: several species grow in the Roman States.)

Perianth with a short tube and 6 spreading lanceolate segments or lobes; filaments hairy; style slender, with 3 bifid subulate branches; capsule oblong. Flowers solitary in a terminal spathe; leaves linear-filiform, usually curved, radical or around the base of the short stem, which bears 1 or more flowers at the end of rather long stiff peduncles ; corm covered by a glossy brown tunic.

Flowers bright purple, twice as long as the spathe....... R. rosea 1.

Flowers smaller, pale violet, slightly exceeding spathe.....R. parviflora 2.

* 1. R. rosea (L.), Eckl. Onion-yrass. Leaves 5-10, 1-2 mm. broad, 10-30 cm. long. doubly grooved on each face, so that a transverse section resembles a Maltese cross; flowers $2-4$, on peduncles much shorter than leaves; upper spathe-valve brown, dotted: perianth $15-25 \mathrm{~mm}$. long, the segments purple inside, with a yellow throat, purple and greenish outside; style and branches shorter than the stamens. 
Pasture and roadsides in southern districts. Sept.-Oct.-South Africa. United by some botanists with the $R$. bulkocodium, Seb. et M., of the Mediterranean region, but the latest monographer, Béguinot, considers that they are distinct species.

* 2. R. parviflora (Salisb.), J. Britten. Leaves even narrower ; flowers slightly exceeding the spathe, 8-10 mm. long, pale-violet, the outer segments green on the outside, with purple stripes; spathe-valves both brown-dotted.-R. Columnae, Seb. et M. (1818); Ixia parviflora, Salisb. (1796).

Pasture and roadsides in southern districts. Aug.-Sept.-Western Europe.

\section{ORTHROSANTHUS, Sweet.}

(Greek orthros, morning; anthos, flower : the flowers open early in the day.)

1. 0. multiflorus, Sweet. Rhizome short; leaves broad-linear, striate, chiefly radical, a little shorter than the stem, which is 40-60 cm. high, rigid ; flowers blue, several, within oblong spathes, some of which are sessile within the subtending bract and others on rigid peduncles, these bracteate clusters rather distant along the stem and forming a long narrow inflorescence; spathe-valves broad, striate; perianths with a short tube and 6 ovate spreading segments; filaments free; style-branches linear; capsule trigonous; seeds longitudinally wrinkled.-Sisyrinchium cyaneum, Lindl.

Kangaroo Island and probably also in the South-East. Oct.-Dec.

\section{HOMERIA. Vent.}

Perianth with a very short tube and 6 subequal spreading segments; filaments united in a tube; style-branches short, broad, truncate; capsule long, cylindrical. Flowers pedicellate, $2-4$ in each of the cylindrical acuminate spathes, which are pedunculate along the stiff flexuose stems; leaves few, grasslike, almost radical; corm with brown tunics.

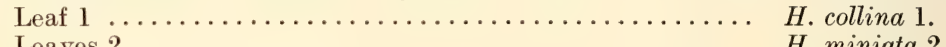

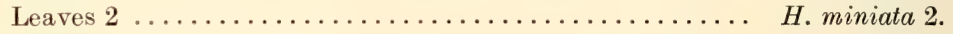

* 1. H. collina (Thunb.), Vent. One-leaved Cape Tulip. Leaf solitary, ribbed, much longer than the stem; perianth-segments $3-4 \mathrm{~cm}$. long, red or pink, with a green or yellow base, sometimes all yellow (var. ochroleuca, Baker).

Pasture in southern districts and South-East. Aug.-Nov. Dangerous to hungry cattle who devour the tough leaves. - South Africa.

* 2. H. miniata, Sweet. Two-leaved Cape Tulip. Leaves 2, usually bearing bulbils in their axils; corm also bearing bulbils; perianth-segments $2-2 \frac{1}{2} \mathrm{~cm}$. long, salmon-pink, with a yellow base blotched with green.

Adelaide plains and Mount Lofty Range. Sept.-Oct.-South Africa.

\section{FAMILY 32 . ORCHIDACEAE**}

Flowers bisexual, zygomorphic, very rarely regular. Ferianth in 2 whorls : the 3 outer segments called sepals, the 2 lateral inner ones called petals, the third petal of this whorl modified (except in Thelymitra and Apostasia) to form a special organ known as the labellum: the latter of diverse shapes and sizes, variously adorned with glandular excrescences, hairs, fringes (Pl. 7, ii., $l$ ), or other appendages (Pl. 8, i., ii., cal.). The male and female elements firmly consolidated with a prolongation of the floral axis, or loosely united (as in Diuris), into a central organ of the flower called the column (Pl. 8, ii., iii., $c_{\text {. }}$. The stamens represented in all Australian species (except Apostasia) by a single fertile anther at the top of the column and by traces of sterile stamens or staminodia (Pl. 6, iii., fig. 9, ap.) modified into wings (Pl. 9, ii., figs. 8, 9,w.), hairtufts (Pl. 6, i., 1, ap.), or other processes. Functional stigmas (Pl. 9, ii., figs. 8, 9 , st.) usually 1 or 2 , situated below the anther; the upper border generally produced into an ill-defined prominence or conspicuous process called the rostellum (Pl. 6, iii., fig. 8, r.), the latter bearing a viscid disk or gland (Text-fig. 33, fig. 1., q.) and representing a sterile stigma. The pollen waxy, granular or mealy, cohering into 1, 2, or 4 pairs of variously shaped pollen-masses or pollinia (Text-fig. 33, fig. 3, p.m.), elastic fibres often connecting together the component parts of the pollinia and produced at their apices into a strap-like extension or caudicle (Pl. 6, iii., fig. 8, cd.). The caudicle when present, adherent to the viscid disk or gland of the rostellum. The viscid disk occasionally produced backwards into 2 false-caudicles or stipes, to which the pollinia adhere. Caudicle and disk sometimes absent. Ovary inferior, 1-celled with 3 parietal placentas ; 3 -celled in Apostasia. Fruit a capsule; seeds without albumen, numerous and very minute. Terrestrial or epiphytical herbs; the former arising from creeping subterranean rhizomes or annually renewed tubers (Pl. 9, ii.) or from fibrous roots; the latter from creeping rhizomes and fibrous roots adhering to rocks or trees. Leaves of varied shape and arrangement. 
A very large cosmopolitan family of plants, represented in this State by 19 genera, all of which are terrestrial. Of these local genera, Dipodium (Text-fig 31.A.) represents the tribe Vandeae, all the rest being members of the Neottieae.

The following terms, not included in the general glossary, are used in the description of the Orchids : antero-lateral, anterior and at the side; cauda, a tail-like appendage ; caudate, furnished with a cauda; chelate, shaped like a lobster's claw; crescentic, crescent-shaped; cusp, a gradually attenuated point; cuspidate, terminating in a cusp; dorsum, the back of an organ; falco-lanceolate, falcate and lanceolate; filamentous, filiform, thread-like; fimbriate, fringed; fistula, the opening in a hollow leaf through which the stem emerges; incumbent, leaning upon another organ ; inturned, incurved; labellar, relating to the labellum ; lamellar, lamellat, laminate, composed of thin layers; lobulate, divided into small lobes; mammillary, nipple-shaped; multipartite, deeply cut into many divisions; patent, spreading; quadrate, square or nearly so ; retracted, turned backwards; retuse, with an obtuse summit, or tip, the centre of which is depressed; rhombo-cuneate, rhomboid in the upper part, cuneate below; rosulate, leaves arranged in a radical rosette; rufous, brownish red; scaphoid, boat-shaped semiovate, ovate on one side only; semiterete, plano-convex; sigmoid, S-shaped ; stigmatic-plate, a vertical plate, in front of or below the anther, bearing the stigma and rostellum, in Thelymitra, Diuris, and other genera.

The following reference-lettering is used in the plates and text-figures which illustrate this family :-
d.s., dorsal sepal.
l.s., lateral sepal.
p., petal.
l., labellum.
cal., callus or calli.
c., column.
a., anther.
ap., appendage.

$h .$, hood.

$w$, wing of column.

st., stigma.

$r .$, rostellum.

$g$. , gland or viscid disk of the rostellum.

p.m., pollen-mass or pollinium.

ov., ovary.

Leaves reduced to scales or bracts.

Flowers large, spotted, white or pink; pollinia waxy....

Flowers minute, reversed, greenish or purple; pollinia

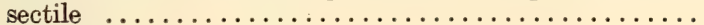

Leaf solitary, quite glabrous.*

Leaf elongated; usually channelled; flowers solitary or racemose; sepals broad, often petaloid.

Labellum densely beset with long hairs.............

Labellum smooth, very similar to the other perianth-

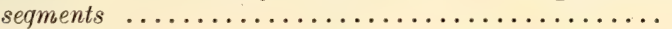

Leaf leek-like; flowers usually in terminal spike or raceme, on short pedicels.

Flowers very small, spicate, green ............ Microt'is 4.

Flowers of variable size, reversed, green to purple...... PrasophyLLum 5.

Leaf linear or narrow-lanceolate; flowers brownish,

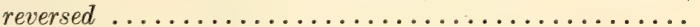

Leaf nearly as wide as long, at or near the base.

Leaf ovate to orbicular-cordate; flower single, large and purplish, close to leaf, galeate, lateral sepals and

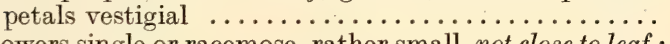

Flowers single or racemose, rather small, not close to leaf ; labellum smooth with 2 callosities at the base, undivided.

Leaf red underneath; labellum acutely triangular;

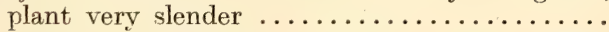

Leaf green underneath; labellum oblong, rather

blunt; plant very slender...............

Flowers single or racemose, of large or medium size; labellum with calli hairs or fringe on lamina or margin

Plant stout, fleshy; flowers large, purplish ; sepals and petals well developed ; labellum 3-lobed, with few sessile calli, fringed at tip .............

Flant slender; labellum densely hairy; sepals petaloid Plant slender; labellum wider than long, smooth, anterior margin toothed, or fringed ...........

Dipodium 1.

Prasophyllum 5.

Calochilus 2.

Thelymitra 3.

Caleana 6.

Corysanthes 7

Actanthus 8.

Cyrtostylis 9.

LYPERANTHUS 10 .

Eriochilus 11.

LEPTOCERAS 12.

* Caladenia Menziesii frequently has glabrous leaves, but for other reasons is not included in this section. 
Leaf solitary, more or less hairy (except in Caladenia Menziesii).

Calli on surface of labellum $\ldots \ldots \ldots \ldots \ldots \ldots \ldots \ldots$

No calli on surface of labellum, but large double-headed appendage at base $\ldots \ldots \ldots \ldots \ldots \ldots \ldots \ldots \ldots$

Leaves more than one.

Labellum 3-lobed.

Petals well-developed, stalked, spreading or recurved...

Petals minute, not stalked, incurved over column . . . . . .

Labellum without lateral lobes.

Flowers small, pink or white, arranyed spirally in a

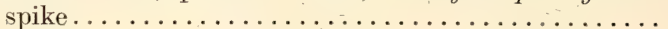

Flowers large, reversed . . . . . . . . . . . . . . .

Flowers green or greenish, generally large, dorsal sepal and lateral petals united to form a hood............

Caladenia 13.

Glossodia 14.

DiURtS 15.

ORTHOCERAS 16.

SPIRANThes 17.

Cryptostylis 18.

Pterostyils 19.

NotE.--The letters N.P. among the locality names denote the National Park, Belair.

\section{DIPODIUM, R. Br.}

(Greek : dis, double ; podion, a little foot : in reference to the 2 stalks, or false-caudicles, of the pollinary apparatus.)

Perianth-segments free, nearly equal, spreading. Labellum sessile, erect, 3-lobed; lateral lobes much shorter than middle one: lamina with a hairy track in middle line. Column erect, semi-cylindrical. Anther terminal, lid-like, deciduous. Pollen-masses 2, waxy, bilobed, attached when mature to the rostellum by a large disk and double stipes produced backwards from the latter. Terrestrial herbs, glabrous, with imbricated sheaths at base of the scape, the upper ones passing into more distant bracts. Flowers spotted.

A small genus including about 9 members. 2 of which are endemic to Australia. Others are reported from New Guinea, New Hebrides, Philippines, and Malayan Archipelago.

1. D. punctatum (spotted), R. Br. Textfig. 31. A. A leafless fleshy plant, 30-75 $\mathrm{cm}$. high; with an extensive system of thick elongated tuberous roots. Flowers often numerous, large, pink or whitish, spotted, in a loose raceme. Perianth segments free, similar, oblong-lanceolate, recurved or spreading; sepals about 17 $\mathrm{mm}$. long, the petals rather shorter. Labellum sessile, erect, about $13 \mathrm{~mm}$. long; 3-lobed; the lateral lobes much shorter than the middle one; lamina with 2 short raised lines from a little below the centre, uniting to form a hairy keel ending in a woolly patch near the apex. Column about half as long as labellum. Anther hemispherical, lid-like, 2-celled. Pollinia 2, bilobed, waxy, attached to a double stipes of the viscid disk. Stigma deeply excavated, transversely oval, just below the rostellum.

N.P. ; higher levels of Mount Lofty Range; Mount Muirhead, near Millicent; also Eastern States and Tasmania. Jan.Apl.

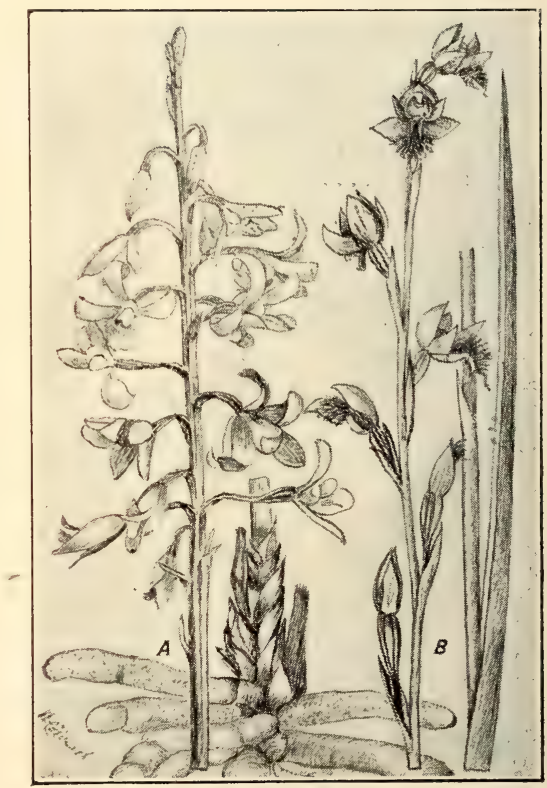

Text figure 31.-A. Dipodium punctatum, showing root-system, base of stem with overlapping scales and intorescence. B. Calochilus cupreus, showing leaf, portion of stem, and inflorescence. All parts much reduced.

\section{CALOCHILUS, R. Br.}

(Greek kalos, beautiful; kheilos, a lip.)

Perianth-segments free. Dorsal sepal broad, erect, hood-like; lateral sepals broad, acute, more or less spreading. Petals shorter than the sepals, wide, erect or incurved. Labellum exceeding the other segments in length, sessile, undivided, with an oblong base and triangular lamina, the latter densely bearded with purple or metallic-colored hairs. Column short and broad, its wide wings produced behind but not beyond the anther. Anther terminal, incumbent or horizontal, with a blunt beak, 2-celled. Pollinia 4 , or 2 each deeply bilobed, granular, unconnected with the rostellum. Terrestrial 
glabrous herbs, with ovoid tubers. Leaf solitary, linear, channelled; bracts sometimes leaf-like. Flowers few or numerous, in a loose raceme.

A small genus of 6 species, one of which occurs in New Caledonia, the others being endemic to Australia.

Base of labellum glabrous, with several raised longitudinal lines, which may be more or less fused .............

Base of labellum covered with purple calli ............

C. cupreus 1.

C. Robertsonii 2 .

1. C. cupreus (copper-colored bracts and flowers), Rogers. Text-fig. 31. B. Flowerstalk 37-60 cm. high. Leaf linear-lanceolate, about 11-15 cm. long, rather rigid and fleshytriangular on section, erect, channelled. Stem-bracts 2, copper-colored, elongate, subulate, clasping. Flowers 8-15, prevailing tints yellow and reddish-brown. Sepals nearly equal in length, yellow with reddish-brown stripes or dots; the dorsal one erect, 8-9 mm. long, ovate, concave, acute; the lateral ones slightly longer and narrower, spreading below the labellum. Petals erect, ovate-lanceolate, shorter and much narrower than the dorsal sepal, yellow with darker stripes. Labellum with fleshy rectangular base and wide triangular lamina, golden-yellow, protruding between and beyond the lateral sepals; margins fringed with reddish-blue hairs with a metallic lustre ; the basal portion glabrous, with brilliant reddish-blue raised lines with a metallic sheen sometimes more or less fused, but all ending in free divergent hair-like extremities ; other hairs on lamina not dense and rather shorter than in other species of Calochilus ; tip recurved and ending in a short, glabrous, sinuous ribbon. Column short and widely winged, very open at the base with purple gland at each lower angle; no castellated ridge connecting the glands, but generally reddish-brown markings between them. Anther long, horizontal, with duck-bill point. Stigma transverse, reniform.

McLaren Vale; also reported from Victoria. Oct.-Nov.

2. C. Robertsonii (after J. G. Robertson, a Victorian botanist), Benth. With the habit of $C$. cupreus, but seldom exceeding $45 \mathrm{~cm}$. in height, and usually with a longer, broader, thinner, and less rigid leaf than in that species. The flowers also fewer, the perianthsegments longer, relatively narrower and less pointed. Flowers usually 2-9, green and purple. Dorsal sepal green, ovate, acute, concave, erect, about $12 \frac{1}{2} \mathrm{~mm}$. long; lateral sepals divergent, spreading below or at the sides of the labellum, as long as the dorsal sepal. Petals very much shorter, yellowish-green, with dark vertical stripe, ovate-falcate, erect. Labellum sessile, about $20 \mathrm{~mm}$. long, similar in shape to that of $C$. cupreus, the lamina covered with crowded purple glands at the extreme base and ending in a short glabrous ribbon, otherwise densely bearded with long purple glistening hairs. Column short and widely winged, a purple gland at each lower angle, these angles connected by a transverse raised purple (often dotted) ridge. Anther almost as long as column, nearly horizontal, bluntly rostrate. Stigma transversely oblong. Rostellum very long and narrow, unconnected with the pollinia. Pollinia 2, each deeply bilobed, crescentic, clubshaped.

N.P. and other parts of Mount Lofty Range; Glencoe ; also reported from New South Wales, Victoria, and Western Australia. Oct.-Nov.

\section{THELYMITRA, Forst.}

(Greek thelymitrs, wearing a woman's head-dress : referring to the hood of the column.)

Segments of the perianth all similar, petaloid, spreading; the labellum undifferentiated from the others. Column medium height, erect, widely winged. The wings united shortly in front at the base; produced on each side of the anther into an appendage, sometimes entire or plumed (Plate 6, i., fig. $1 \mathrm{ap}$.) or decorated with various excrescences ; commonly produced behind and over the anther, so as to form a more or less complete, often bilobed hood (fig. 1, 3, h). Anther 2-celled, erect or incumbent, its connective often produced into an appendage entire or bifid. Pollinia 2, each deeply bilobed or in 2 pairs, attached directly or by means of a short caudicle with the disk of the rostellum or sometimes quite unconnected with it, mealy or granular. Stigma large, borne on a plate usually below the anther or more or less concealing the latter. Viscid disk well developed and situated in a slot or depression in the upper border of the stigma. - Terrestrial glabrous herbs, with 2 rounded or ovoid subterranean tubers. Leaf solitary, generally much elongated and fluted, very rarely wide and ovate-lanceolate or terete. Flowers one or many in a terminal raceme. Albino forms not infrequent.

A genus of about 42 species, having Australia apparently as a distributing centre, but recorded also from New Zealand, New Caledonia, Timor, Java, and the Philippines.

Column-wings produced at the sides and behind the anther so as to form a hood; the lateral lobes bearing hair-tufts (penicillate).

Hood with 3 short denticulate lobes between the penicillate ones.

Middle lobe of hood shorter than adjacent divisions, crested on back ; hair-tufts white; flowers light-blue,

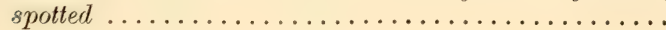


Middle lobe of hood shorter than adjacent divisions, smooth on back; hair-tufts purple; flowers deep

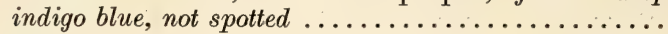

Middle lobe of hood longer than adjacent divisions, latter incurved, smooth on back; hair-tufts white; flowers greyish-green, or brown, with metallic lustre ..

Hood with one entire or bifid lobe between the penicillate ones.

Lobe between hair-tufts undivided or with crenate margin.

Upper border middle lobe truncate, horizontal, slightly denticulate; hair-tufts white; flowers

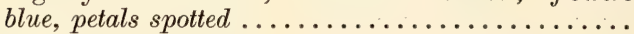

Upper border of middle lobe convex, crenate ; hairtufts yellow ; flowers pinkish or light-red .........

Lobe between hair-tufts bifid or emarginate.

Crest of middle lobe much higher than hair-tufts, its profile falcate; plant largest in the genus; flowers

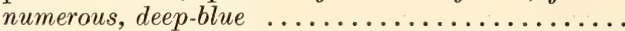

Middle lobe dilated, its crest about level with hairtufts ; plant medium size ; flowers several, lavender,

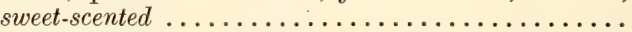

Middle lobe only slightly notched, somewhat tubular, not dilated; plant medium size; flowers

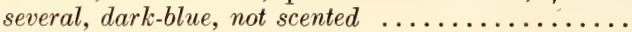

Middle lobe very deeply cleft; plant small, slender; flowers generally 1-3, dark-blue, small ...........

Hood deeply toothed or fringed, without penicillate lobes; with a club-shaped appendage on the back; leaf ovate-

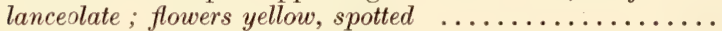

Column-wings produced behind the anther, truncate, not hood-shaped, their lateral lobes not bearing hair-tufts.

Wings at the back produced higher than anther; lateral lobes nearly horizontal and more or less rugose.

Flowers 1 or 2, small, yellow inside, sepals dark-red outside, red in the bud; leaf linear ............... Flowers 1-3, rather larger than T. urnalis, pink to

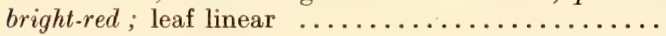

Wings at back not produced so high as anther; lateral lobes very small, much exceeded by the thick pubescent anther-point; flowers small, yellow; leaf terete........

Column-wings not produced behind anther; lateral lobes erect or almost so, and at least as high as the anther.

Lateral lobes smooth, reddish-brown, emarginate, higher than anther; flowers 1-3, large, yellow inside, sepals reddish. brown, outside, reddish in bud; leaf terete ..........

Lateral lobes denticulate, yellow, much higher than anther; flowers 1-3, salmon-colored or pinkish; leaf linear......

Lateral lobes spirally involute; flowers blue, veined, delicate ; leaf linear..........................

T. azurea 2.

T. epipactoides 3 .

\section{T. truncata 4.}

T. luteociliata 5.

T. grandiflora 6 .

T. aristata 7.

\section{T. longifolia 8.}

T. pauciflora 9.

T. fuscolutea 10.

T. urnalis 11.

T. carnea 12

T. flexuosa 13.

\section{T. antennifera 14.}

T. Macmillanii 15.

T. venosa 16.

1. T. ixioides (Ixia-like) Sw. Slender, 20-60 cm. high. Leaf long, linear, channelled. Flowers on very slender pedicels, about 2-6, blue on inside with spotted dorsal sepal and petals; the sepals reddish-purple on the outside. Perianth-segments (including labellum) not very acute, about $8.9 \mathrm{~mm}$. long, elliptical. Column erect, about $4 \mathrm{~mm}$. long; wings extended upwards and forwards on either side of anther, ending in white hair-tufts ; between the penicillate lobes 3 shorter truncate denticulate ones, the central much shorter than the others and crested with several rows of calli on the back. Anther slightly above the stigma and rostellum, its blunt point produced a little above the bases of the penicillate lobes. Pollinia concealed behind stigma.

N.P., Mount Lofty Range; Encounter Bay; Inman Valley; Naracoorte ; Mount Compass district; Kangaroo Island; also in all other States. Oct.-Nov.

2. T. azurea (deep sky-blue flowers), Rogers. A slender species, usually $10-35 \mathrm{~cm}$. high. Leaf rather long, narrow-linear, often filiform. Flowers a deep azure blue, 1-12. Segments of the perianth veined, $8-9 \mathrm{~mm}$. long. Column rather widely winged, with purple hair-tufts directed upwards and forwards; the hood between the hair-tufts purple with yellow margin and deeply 3 -lobed, the central division denticulate shorter than and often overlapping the adjacent ones, the latter with smooth upper borders. Anther 


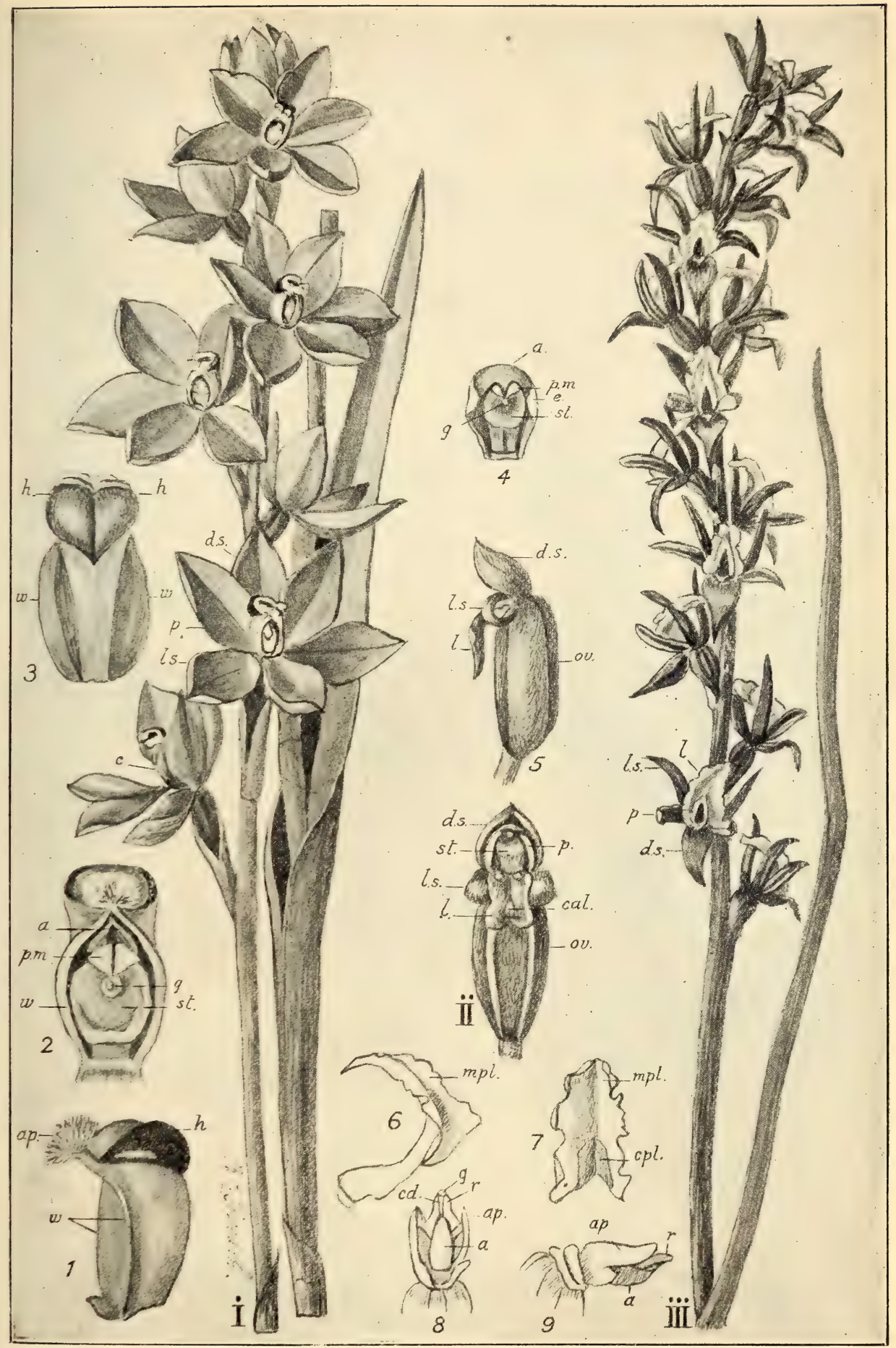

Plate 6.

i. Thelymitra aristata, natural size. Fig. 1.-Side view of column (enlarged); ap, hair-tufts; $h$, hood: Fig. 2.-Front view of column (enlarged) Fig 3.-Back view of column (enlarged).

ii. Microtis porrifolia, a flower (front view) enlarged; cal., a callus near the tip of labellum, 2 more are seen at the base. Fig. 4.-Front view of column (enlarged); $e$, auricle. Fig. 5.- Side view of flower

iii. Prasophyllum odoratum, spike and leaf nat. size. Fig 6.- Side view labellum (enlarged). Fig. 7.-Front view labellum (enlarged); m.p l., membranous part; c.p.l, callous part Fig. 8.-Column from back (enlarged); ap, lateral appendages; c.d., caudicle. Fjg 9.-Colımn from side (enlarged.) 
almost concealed behind the stigma, its point moderately long. Pollinia 2, deeply bilobed, connected by short caudicle to the rostellum. Stigma large, ovate. Rostellum prominent.

Between Mount Compass and Port Elliot; Geranium. Oct.-Nov.

3. T. epipactoides (Epipactis-like), F. v. M. A plant of robust habit, $21-52 \mathrm{~cm}$. high. Leaf long fleshy, lanceolate, tubular at the base; stem-bracts 1 or 2, leafy. Flowers 6-18, large, pedicellate, usually of a peculiar iridescent greyish-green color shot with pinkish tints, sometimes brown with a metallic lustre. Perianth-segments ovate-lanceolate, about 10-11 mm. long. Column widely winged, hair-tufts white, turned upwards; segment between the hair-tufts deeply 3 -lobed; the central division incurved, irregularly denticulate at the top, and reaching a higher level than the adjacent ones ; lateral divisions denticulate with oblique tips, passing upwards and inwards and often interlocking like the fingers of two hands. Anther, with exception of its point, concealed behind the stigma. Stigma situated well below the middle of column.

Meningie; Myponga; Monarto South; Tailem Bend; Goolwa; Inman Valley; also Victoria. Sep. and early Oct.

4. T. truncata (truncate middle lobe of hood), Rogers. A species of slender habit, about $30 \mathrm{~cm}$. high. Flowers 2-6, blue, petals spotted. Column rather widely winged; hair-tufts white, projecting upwards and forwards and rather higher than the middle lobe; lobe between the hair-tufts a truncated yellow cone, undivided, its upper border slightly denticulate, its back not crested. Anther with well marked point, a considerable portion showing above the stigma. Stigma large, somewhat quadrangular; the viscid disk situated in a deep depression in its upper border.

Myponga. End of Oct.

5. T. luteociliata (yellowish-hairtufts), Fitzg. Slender, 15-37 cm. high. Leaf long, fleshy, slightly channelled, narrow-linear to rather broadly-linear. Flowers pinkish or light red, generally $2-5$ on slender pedicels; rarely expanding. Perianth segments oblonglanceolate, not very acute, 7-8 $\mathrm{mm}$. long. Column erect, 4-5 mm. long, wings not very wide, hairtufts yellow, turned upwards; lobe between the hairtufts with a convex crenate margin, less distinctly hooded than in most members of this section. Anther situated above the stigma, its rather blunt triangular point projecting between the hairtufts, dehiscing in the early bud. Stigma semicircular, oblique, the lateral wings of column uniting to form a cup-like depression at its base. Rostellum situated in middle of upper border of stigma. Pollinia 4 (in 2 pairs) connected directly with viscid disk.

N.P. and Mount Lofty Range; Eyre Peninsula, and Kangaroo Island; also Victoria. Sept.-Oet.

6. T. grandiflora (large-flowered), Fitzg. The most robust member of the genus, $35-75 \mathrm{~cm}$. high. Leaf widely lanceolate, sheathing for several inches at the base, thick, dottted or spotted, generally enclosing base of lowest bract. Stem-bracts 3 or 4, large, acute, lower ones leafy. Flowers purple-blue, usually numerous in a long raceme, about $3 \mathrm{~cm}$. in diameter. Perianth-segments rather acute, concave, oblong-lanceolate, 13-16 mm. long, the labellum narrower than other segments. Column erect, 6-7 mm. high, hooded; wings wide and inflated, hairtufts white, horizontal; intermediate lobe arched, bifid, the segments deeply denticulate, the crest higher than the hairtufts, the profile falcate. Anther wholly concealed behind the stigma. Pollinia 4 (in 2 pairs), lamellar (plate-like) connected directly with the viscid disk, no caudicle. Stigma ovate, situated unusually low down in the concavity of the column below the middle. Rostellum prominent, viscid.

N.P.. Mount Lofty Range; Goolwa; Wardlow Vale; Hughes' Gap (Flinders Range); Kangaroo Island; also Victoria. Oct.-Nov.

7. T. aristata (bearded, referring to the hair-tufts), Lindl. (Pl. 6, i., figs. 1-3.) Moderately stout, seldom exceeding $40 \mathrm{~cm}$. high. Leaf sheathing towards the base, often $15-22 \mathrm{~cm}$. long and $7.12 \mathrm{~mm}$. wide, lanceolate, rather flat. Flowers mauve or lavender, sweetscented, $3-8$, about $2 \frac{1}{2} \mathrm{~cm}$. in diameter, perianth-segments elliptical-lanceolate, $13-15 \mathrm{~mm}$. long ; readily expanding in sunshine. Column erect, hooded, about $6 \mathrm{~mm}$. high ; hairtufts (fig. 1, ap.) white, horizontal ; intermediate lobe cap-shaped, dilated laterally, darkbrown towards the back, yellow towards the front, sometimes cayenne-pepper-colored, with a $V$-shaped notch in the centre, crest reaching to about the level of the hair-tufts. Anther with short blunt point, only extreme base concealed by stigma. Pollinia 2, each deeply bilobed, attached directly to viscid disk.

N.P. and other parts of Mount Lofty Range and seacoast ; widely distributed; also in all other States except Queensland. Sept.-Nov.

8. T. longifolia (long-leaved), Forst. Of variable stature, usually slender, $30-60 \mathrm{~cm}$. high; sometimes rather robust. Leaf very variable, often long and narrow. Flowers blue, not scented, rather large, occasionally solitary but commonly 2-6 in a raceme. Perianth-segments rather acute, $13-15 \mathrm{~mm}$. long. Column erect, about $6 \mathrm{~mm}$. high, hooded; hairtufts white, bent upwards; intermediate lobe very dark-colored except at margin, only slightly notched, arched and somewhat tubular, not laterally dilated 
as in $T$. aristata, erect, higher than hairtufts. Anther largely concealed by stigma and rostellum.

N.P. and other parts Mount Lofty Range ; Bordertown ; Cavanaghville ; Kangaroo Island; Mount Patawurta (Flinders Range); also in all the other States. Oct.-Nov.

9. T. pauciflora (few-flowered), R. Br. Of slender habit, 10-30 cm. high. Leaf narrowlinear, rather long, channelled. Flowers blue, occasionally white, small, frequently solitary, seldom exceeding 3 ; only opening in very hot weather. Perianth-segments not very acute, about $7 \frac{1}{2} \mathrm{~mm}$. long. Column erect, about $5 \frac{1}{2} \mathrm{~mm}$. long, hooded; hairtufts white, turned upwards ; intermediate lobe brownish, very deeply and narrowly cleft, the divisions rounded, entire, its crest rather higher than the hair-tufts. Anther only concealed by stigma at extreme base. Stigma situated low down. Rostellum prominent, viscid. Pollinia in 2 pairs. No caudicle.

N.P. and other parts of Mount Lofty Range; Kangaroo lsland; also in New South Wales; Victoria; and Western Australia. Oct.-Nov.

10. T. fuscolutea (brown-yellow), R. Br. Generally rather stout, $15-45 \mathrm{~cm}$. high. Leaf the widest in the genus, ovate-lanceolate to oblong-lanceolate, contracted and sheathing at base, dimensions very variable, ranging from $4-12 \mathrm{~cm}$. long and $1 \frac{1}{2}-5 \mathrm{~cm}$. wide. Flowers 2-6, large, yellowish marked with dark-brown spots, about $2 \frac{1}{3} \mathrm{~cm}$. in diameter. Perianthsegments elliptic-lanceolate, acuminate, $14-16 \mathrm{~mm}$. long. Column 7-8 mm. long including wings, but very short (only $2 \mathrm{~mm}$.) below the anther; wings voluminous, produced behind and beyond the anther in form of a canopy or broad hood, without definite lateral lobes, the upper margins dissected into dentate or linear processes, a dorsal thickening from the base produced upwards into an undivided clavate appendage rather shorter than the linear processes, the summit of the hood in front of the appendage densely woolly. Anther at its apex produced into a long recurved finger-like process; concealed, with exception of its apex, behind the stigma. Stigma situated in the concavity formed by the wings at base of column. Rostellum prominent in upper border of stigma. No caudicle.

Mount Lofty Range; Myponga; Kangaroo Island; also Victoria and Western Australia. Nov.-Dec.

11. T. urnalis (urn-shaped column), Fitzg. A slender plant 10-30 cm. high. Leaf long, linear, channelled, often reaching the base of the inflorescence. Flowers small, 1 or 2, vellow inside, the sepals dark red-brown on the outside, buds reddish on outside. Perianth-segments rather wide, acute, about $6 \mathrm{~mm}$. long, opening in warm sunshine. Column about $f \mathrm{~mm}$. long, not hooded, but wings produced above the anther ; the lateral appendages not ciliate but broad, horizontal, and rugose, the lobe between them undulate or almost denticulate; wings united in front of the column at the base and sometimes produced upwards in the form of a central spur in front of the stigma, giving the column an urn-like appearance. Anther 2-celled, obtuse, slightly emarginate, protruding above the stigma, after dehiscence carried upwards with the growth of the column, leaving the pollen-masses attached to the rostellum. Pollinia 4 (in 2 pairs) attached directly to the viscid disk and easily removed on a needle.

N.P. ; Mount Lofty ; Bugle Ranges. Oct.

12. T. carnea (flesh-colored), R. Br. A very slender species, usually $15-30 \mathrm{~cm}$. high. Leaf very narrow-linear, channelled. Flowers 1-3, rather small, pink or red, expanding in bright sunlight. Perianth-segments obtuse, elliptical or oblong-elliptical, about $9 \mathrm{~mm}$. long. Column about $5 \mathrm{~mm}$. long, erect, not hooded; wings produced laterally into 2 denticulate and more or less roughened yellow horizontal lobes, rather higher than the anther; intermediate lobe rather broad, reddish, slightly denticulate, rather higher than the lateral ones. Anther somewhat blunt, its lower half concealed behind the stigma.

N.P. and other parts of Mount Lofty Range; Angaston; Inman Valley; Delamere ; Millicent district; Yeelanna; Kangaroo Island; also in all extra-tropical States. Oct. Nov.

13. T. flexuosa (zig-zag stem), Endl. A very slender species, usually $15-20 \mathrm{~cm}$. high. Lenf terete above its opening, about $7.8 \mathrm{~cm}$. long. Stem very wiry, zig-zag; stem-bracts 2. situated at points of flexion. Flowers small, yellow, 1 or 2 , opening on hot days. Perianth-segments very obtuse, outer ones concave, ovate, inner ones oval, about $7 \mathrm{~mm}$. long, the labellar segment rather shorter and narrower than the others. Column erect, about $4 \frac{1}{2} \mathrm{~mm}$. high, not hooded, widely winged; the wings only very slightly produced at the sides into rounded dentate lobes; the intermediate lobe slightly notched and rather higher than the lateral lobes; all very much shorter than the anther. Anther situated entirely above the stigma, apex produced into a large oblong fleshy downy process greatly exceeding the lobes of the wings. Pollinia 4 (in 2 pairs), directly connected with the viscid disk. Stigma somewhat rectangular.

N.P. and other parts of Mount Lofty Range; Inman Valley; Kangaroo Island; also Victoria; Tasmania; and Western Australia. Oct.-Nov. 
14. T. antennifera (antennae-bearing; referring to the lateral appendages of the column), Hook. f. Stouter than T. flexuosa, generally $12-20 \mathrm{~cm}$. high. Leaf terete and rather long, stem wiry, zig-zaig; stem-bracts 2, situated at angles of flexion. Flowers large, 1-3, yellow, opening freely, sweet-scented. Perianth-segments yellow on the inside, the sepalar ones with wide reddish-brown stripe externally, elliptical or oblong-elliptical, about 15-16 mm. long. Column erect and rather wide, not hooded, broadly winged : the wings produced laterally into 2 erect dark-brown smooth spathulate usually bilobed appendages, much longer than the anther, the part between the appendages not produced behind the anther. Anther 2-celled, situated wholly above the stigma, its apex produced into a broad thick curved pubescent blunt process. Stigma transversely oval, situated low down on the column; rostellum conspicuous in its upper border. Pollinia 2, each bilobed, attached directly or by a very short caudicle to the viscid disk.

N.P.; very common, widely disseminated; also in Victoria ; Tasmania ; and Western Australia. Sept.-Oct.

15. T. Macmillanii (after its discoverer, Thomas Macmillan, of Melbourne), F. v. M. Slender, $12-20 \mathrm{~cm}$. high. Leaf narrow-linear, channelled, 5-9 cm. long. Stem slender, wiry, and usually slightly flexuose. Flowers large, salmon-red, 1-3, expanding freely. Perianth-segments elliptical or oblong-elliptical, about 12-16 $\mathrm{mm}$. long, occasionally still smaller. Column erect, 6-7 mm. high ; the wings produced laterally into 2 tall erect yellow lanceolate appendages with serrate margins and smooth surfaces, not produced behind the anther where they form a deep sinus. Anther and stigma as in T. antennifera.

N.P. and other parts of Mount Lofty Range; Yatala Vale; Yallum ; Burnside ; Goolwa; also Victoria. Sept.-Oct.

16. T. venosa (veined, referring to perianth-segments), $\mathrm{R}$. Br. A slender species, usually $15-75 \mathrm{~cm}$. high. Leaf narrow-linear, channelled, often extending beyond middle of scape. Stem rather sinuous. Flowers large, blue, on long slender pedicels, 1-5. Perianth-segments rather thin and veined; outer ones slightly longer than the inner, about $13-14 \mathrm{~mm}$. long; labellum more differentiated than in other members of the genus, usually ovate or nearly orbicular, about. $12 \mathrm{~mm}$. long and $7 \frac{1}{2}-9 \frac{1}{2} \mathrm{~mm}$. wide. Column erect, about $5 \mathrm{~mm}$. long, widely winged, not hooded; wings produced laterally into 2 blunt erect spirally involute appendages, not ciliate or roughened, not produced at the back of anther. Anther very protuberant, overhanging the stigma; its apex prolonged and bifid, about as high as the lateral appendages. Pollinia unconnected with the rostellum. Stigma placed obliquely below the anther, its upper margin bicuspidate.

In swampy country at Myponga and Mount Compass; also in New South Wales, Victoria, and Tasmania. Dec.

4. MICROTIS, R. Br.

(Greek mikros, small ; ous, an ear.)

Flowers small, numerous, in a terminal spike. Dorsal sepal hooded, erect, broad; lateral sepals approximating to it in length, lanceolate or oblong, spreading or recurved. Petals shorter or nearly equal in length to sepals, incurved or spreading. Labellum sessile, obtuse, truncate or emarginate, oblong, ovate or orbicular ; lamina with callosities at the base or along the centre, or quite smooth. Column very short and relatively wide, nearly terete with a small wing or auricle (Pl. 6, ii., fig. 4,e) on each side of anther. Anther erect, 2-celled. Pollen-masses 2, each bilobed, granular, caudicle often very short or sometimes absent. Terrestrial glabrous herbs, with small underground tubers. Leaf solitary, lamina elongate and terete.

The genus has representatives in New Zealand; New Caledonia; Java; Philippines ; Formosa; and China. Nine species have been recorded in Australia, 7 of these being endemic.

Lateral sepals recurved or revolute in the mature flower.

Labellum emarginate at tip ; 2 well-defined callosities at

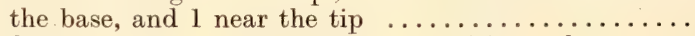

Labellum entire ; 2 well-defined callosities at base, none

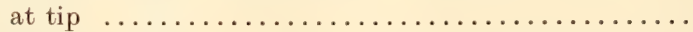

Lateral sepals spreading, not recurved or revolute.

Labellum orbicular; lateral sepals acute and linear,

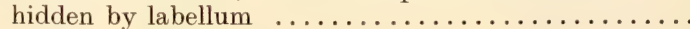

Labellum oblong or quadrate ; lateral sepals very blunt,

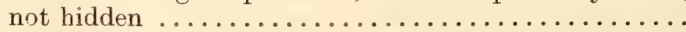

\section{M. porrifolia 1.}

M. parviflora 2.

\section{M. orbicularis 3 .}

M. atrata 4.

1. M. porrifolia (leek-leaved), Spreng. (P1. 6, ii., figs. 4, 5.) Of variable habit, but usually more robust than other members of the genus ; sometimes quite short but commonly upwards of $20 \mathrm{~cm}$. Leaf-lamina leek-like and often exceeding the inflorescence. Flowers green, small, numerous in a dense terminal spike, but occasionally distant in a slender spike. Dorsal sepal erect, shortly acuminate, galeate, broadly ovate, usually exceeding $2 \mathrm{~mm}$; lateral sepals slightly shorter, spreading, recurved, oblong, rather blunt. Petals oblong erect, partially concealed by the dorsal sepal, shorter and narrower 
than the lateral ones. Labellum sessile, oblong, with crisped or irregular margins; tip quite blunt, or more or less emarginate ; lamina with 2 raised callous thickenings at the base and a central one (Plate 6, ii., cal.) near the tip ; about the same length as the lateral sepals. Column about $1 \mathrm{~mm}$. long. Anther 2 -celled, with minute point, hemispherical ; auricles (fig. 4, e.) quite distinct, blunt, reaching about half way up the sides of the anther. Stigma prominent, semiorbicular. Rostellum viscid, conspicuous. Pollinia 2, each very deeply bilobed, friable, attached by a moderately long caudicle to the rostellum ; easily detached with the disk when fresh.

N.P. Very common. Recorded as far north as Crystal Brook; also in all other Australian States. Oct.-Dec.

2. M. parviflora (small-flowered), R. Br. Slender, $7-45 \mathrm{~cm}$. high. Leaf-lamina leeklike, usually much exceeding the inflorescence. Flowers green, on short pedicels, smaller than those of $M$. porrifolia, commonly in a fairly dense spike, but the latter often attenuated. Dorsal sepal galeate, ovate, with a short recurved point, nearly $2 \mathrm{~mm}$. long; lateral sepals shorter, about $1 \frac{3}{4} \mathrm{~mm}$, oblong, rather blunt, recurved or rarely revolute. Petals blunt, oblong-linear, erect, partly hidden by the dorsal sepal, about $1.3 \mathrm{~mm}$. long. Labellum oblong, ovate-oblong or ovate, with rounded or sometimes rectangular tip, about $1 \frac{1}{2} \mathrm{~mm}$. long; recurved or simply reflexed, with 2 elongated elliptical callosities at the base ; margins entire and quite smooth. Column hardly $1 \mathrm{~mm}$. long, with a distinct and rather prominent rounded auricle on each side of the anther. Anther hemispherical. Pollinia 2, each bilobed, attached to the viscid disk by a very short caudicle. Stigma semilunar, situated transversely between the auricles.

N.P. ; Bridgewater; Myponga ; also all other States. Dec.

3. M. orbicularis (disk-shaped labellum), Rogers. A very slender species, $15-30 \mathrm{~cm}$. high. Leaf-lamina shorter than the spike, the fistula situated just below the latter at $a$ characteristic angulation in the stem. Spike not crowded, and with a flatter appearance than in other members of the genus. Flowers green, minute, sessile. Dorsal sepal obtuse galeate, gradually narrowing towards the base, about $1 \frac{1}{4} \mathrm{~mm}$. long ; lateral sepals about same length, linear-oblong, blunt, concealed below the labellum. Petals rather narrower than the lateral sepals, about $1 \frac{1}{4} \mathrm{~mm}$. long, spreading transversely, slightly recurved. Labellum orbicular, margin entire, lamina somewhat concave, reflexed, about as long as the lateral sepals. Column very minute, about $\frac{3}{4} \mathrm{~mm}$. high, with distinct linear auricles. Rostellum protuberant, as a dark-green dot. Anther 2-celled, galeate. Pollinia attached to rostellum by a rather long caudicle.

Myponga; Mount Julian. Early Nov.

4. M. atrata (blackened, in allusion to the dark color of the dried plants), Lindl. A minute species, 3-9 $\mathrm{mm}$. high, Leaf-fistula close to the inflorescence, lamina exceeding the latter in length. The whole of the living plant including the flowers a yellowishgreen color. Flowers very minute in a somewhat dense spike of $1-3 \mathrm{~cm}$. long; ovary tumid, sessile. Dorsal sepal very obtuse, widely galeate, about $0.8 \mathrm{~mm}$. long; lateral sepals oblong, blunt, spreading but not recurved, nearly as long as the dorsal sepal. Petals rather shorter than lateral sepals but similar, spreading. Labellum about $0.8 \mathrm{~mm}$. long; oblong or quadrate ; spreading or reflexed; the tip quite blunt ; margins entire ; lamina with 2 longitudinal lines, no callosities. Column about $0.6 \mathrm{~mm}$. high, rather rugose and glandular. Anther hemispherical, 2-celled. Auricles fairly long. Pollinia 2, each bilobed, connected directly with viscid disk; no caudicle. Stigma semilunar ; rostellum showing as a dark-green dot in upper border.-M. minutiflora, F. v. M.

N.P. and other parts of Mount Lofty Range in damp places; Myponga ; Mount Gambier; also in Victoria; Tasmania; and Western Australia. Nov.

\section{PRASOPHYLLUM, R. Br.}

(Greek prason, a leek ; phyllon, a leaf.)

Flowers reversed. Dorsal sepal lanceolate, or broad and acute, concave, sometimes erect and arched over the column, more frequently recurved; lateral sepals as long or longer, usually more or less lanceolate, free or partially united (connate). Petals shorter, lanceolate or linear. Labellum sessile or attached by a short claw to the base of the column; ovate, oblong or lanceolate; undivided; margins of lamina crisped, ciliate denticulate or entire; its surface with a longitudinal central callus (Pl. 6, iii., 7, cpl.) occasionally with free margins; usually erect and concave at the base, recurved towards the end. Column very short below the anther; its margins produced into 2 erect lateral appendages (figs. 8, 9. ar.) usually adnate to the basal margins of the stigmatic-plate.* Anther 2-celled, erect behind the stigmatic-plate; the rostellum often produced beyond it, but sometimes shorter. Pollinia 2, each bilobed, sectile, attached by a linear caudicle to the glandular disk of the rostellum. Terrestrial glabrous herbs with ovoid or globular tubers. Leaf solitary; lamina terete, but in the diminutive members of the

* A vertical plate in front of the anther, consisting of a basal portion or expanded style, and an upper portion bearing the stigma and rostellum. 
genus reduced to a brast in the flowering season. Flowers several or numerous in a terminal spike, usually inconspicuous in color, commonly greenish, white or purple, sometimes fragrant.

The genus has representatives in New Zealand, but is otherwise exclusively Australian. About 60 valid species have been recorded.

Leaf fully developed at time of flowering; flowers not minute.

Lateral sepals connate in the bud and in the freshlyexpanded flower.

Labellum acutely or abruptly flexed about the middle.

Labellum conspicuously white; callous part prominently raised, ending close to the bend; ovary long and very slender ..................

Labellum green; callous part not much raised, ending much beyond the bend; ovary very short and turgid $\ldots \ldots \ldots \ldots \ldots \ldots \ldots \ldots \ldots \ldots$

Labellum not acutely or abruptly flexed ; callous part extending much beyond bend.

Plant very tall and robust; flowers green. sometimes almost black ; labellum not constricted ; callous part with free margin ................

Plant slender: labellum with conspicuous lateral constriction near the tip, callous part raised and ending abruptly beyond the constriction.

Flowers usually green, occasionally dark-prune colored; labellum on well-marked claw ..... Flowers prune-colored; labellum sessile ...... Lateral sepals always free.

Labellum acutely flexed about the middle.

Labellum conspicuously white ; lateral appendages

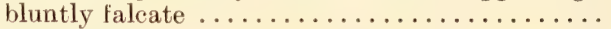

Labellum white, but not conspicuously so : lateral appendages acutely lanceolate with a third linear intermediate lobe ...............

Labellum not acutely flexed.

Labellum with membranous portion wider than

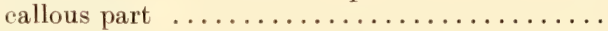

Labellum with callous part wider than membranous and reaching nearly to the tip.

Flowers green or yellowish-green; little or no perfume ...........

Flowers with prune-colored labellum; callus velvety; very powerful odor ............

Leaf undeveloped at time of flowering or represented only by a small bract.

Labellum not ciliate.

Labellum petals and usually dorsal sepal dark-purple; former about equal in length to dorsal sepal and narrowing abruptly to a very acute point ; lateral

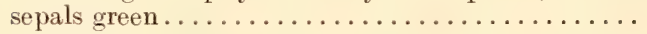

Labellum dark reddish-brown, shorter than the dorsal sepal, very convex, tip very blunt; sepals and

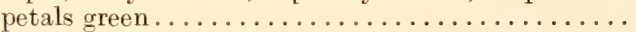

Labellum ciliate deep purple; other segments yellowish-

green with pale-purple linear markings ......... P. intricatum 13.

1. P. australe (southern), R. Br. Often slender, $25-75 \mathrm{~cm}$. high. Leaf-lamina usually shorter than the spike. Flowers sessile, on a very slender terete elongated ovary often upwards of $10 \mathrm{~mm}$. long, in a rather loose spike, sweet-scented, with prevailing tints of white brown and green. Segments of perianth all very acute; sepals yellowish-green and nearly equal in length; the dorsal one about $8 \mathrm{~mm}$. long, erect or recurved, concave, ovate-lanceolate: the lateral ones sometimes free at extreme base, united beyond this almost to the tips. Petals erect, yellowish-green with wide reddish-brown stripe down the centre, narrower and rather shorter than the lateral sepals. Labellum conspicuously white, sessile with bulging erect base; acutely reflexed about the middle; the free end voluminous, much crisped. with undulate margins; callous part ending abruptly in 2 much elevated knuckles at the bend. Anther erect, with short point, 2-celled, not so high as rostellum. Lateral appendages lanceolate-falcate, adnate in front to the pedicel of the stigmatic-plate, the basal lobes thickened and sinuous, about equal in height to the rostellum. Viscid disk large, ovate, situated in a triangular depression on the front 
of the apex of the rostellum. Stigma large, prominent, somewhat pentagonal. Caudicle rather long. Pollinia 2, biloked.

Mount Compass; Myponga; Mount Lofty Range; Glenelg River; Kangarou Island; also from all other Australian States. Dec.

2. P. occidentale (western), Rogers. Rather dwarf, $12-20 \mathrm{~cm}$. high. Fistula of leaf high up, sometimes just below the spike; leaf-lamina greatly exceeding the spike. Flowers rather small. green, sessile or almost so ; ovary short and turgid; in a moderately loose spike of 10-16 flowers. Dorsal sepal erect or retracted, ovate-lanceolate, about $5 \mathrm{~mm}$. long, very acute, concave; lateral sepals lanceolate, slightly bidentate, nearly $6 \mathrm{~mm}$. long, concave on their inner surfaces, united for about three-quarters of their length in the freshly expanded flower, but sometimes quite free in the older flower, especially in very hot weather. Petals nearly same length as the dorsal sepal, lanceolate, erect or slightly spreading. Labellum sessile, acutely or abruptly reflexed about the middle, ovatecuneate, about $5 \mathrm{~mm}$. long and $2-6 \mathrm{~mm}$. wide ; erect portion almost orbicular with entire margins, slightly bulging at the base; reflexed part oblong-cuneate with crisped or crenulated edges and acute tip ; callous plate not very prominent until beyond the bend, then contracted into a much narrower and more elevated apical extension and ending abruptly midway between the bend and the tip ; membranous part about equal in extent to the callous. Column very short and wide. Anther with very short point, about same height as rostellum. Lateral appendages erect, oblong, with obliquelv truncated tips, about as high as rostellum, the basal lobes reaching to about their middle, adnate below the stigma to the sides of the stigmatic-plate. Stigma transversely reniform. Caudicle of medium length.

Streaky Bay. End of Sept.

3. P. elatum (tall), R. Br. The most robust member of the genus, ranging in this State from $45-120 \mathrm{~cm}$. high. Leaf-lamina usually rather short, but occasionally exceeding the spike; the whole plant varying in color from a pale-green to dark-purple or almost black. Flowers large sessile, on a narrow elongated terete ovary. Dorsal sepal lanceolate, about $10 \frac{1}{2} \mathrm{~mm}$. long, moderately acute, concave, erect or recurved; lateral sepals united from about the middle almost to the tips, falco-lanceolate, about $10 \mathrm{~mm}$. long. Petals about the same length but much narrower, falcate-lanceolate, generally spreading. Labellum sessile, not bulging at the base; ovate, about $8 \mathrm{~mm}$. long and $6 \frac{1}{2} \mathrm{~mm}$. wide, slightly recurved from about the middle ; basal margins entire, those in front corrugated ; callous part ovate, occupying most of the lamina and ending about midway between the bend and the tip, with free crenulated lateral margins united anteriorly. Anther erect, 2 -celled, with a short acute point, of varying height but usually at the same level as the rostellum. Rostellum long and narrow, with a large ovate disk. Pollinia 2, deeply bilobed, attached to the disk by a rather long caudicle. Lateral appendages bluntly linear-falcate, very long, much exceeding the rostellum, with a small thickened basal lobe, not adnate to the stigmatic-plate. Stigma prominent more or less rounded or shield-like.

N.P. and other parts of Mount Lofty Range ; Port Victor district ; Beetaloo ; Moonta ; Cummins; Yeelanna; Kangaroo Island; also all other States except Queensland. Oct.-Nov.

4. P. gracile (slender), Rogers. Slender, usually upwards of $30 \mathrm{~cm}$. high. Leaflamina shorter than the spike. Flowers yellowish-green, more rarely dark-purple, arranged in moderately loose spike. Dorsal sepal about $10 \mathrm{~mm}$. long, ovate-lanceolate, incurved; lateral sepals about $11 \mathrm{~mm}$. long, united in their basal third in freshly expanded flowers, subulate, with bidentate points, narrow. Petals about $9 \mathrm{~mm}$. long; linearlanceolate, tips incurved. Labellum on a well-marked claw, recurved but not acutely near the middle; erect part deeply concave with entire margins ; the part in front of the bend narrow, triangular with sharp point, margins slightly undulate with marked constriction a little beyond the bend; membranous part white and glandular, nearly equal in extent to the callous portion; the latter raised in front of bend and ending abruptly just beyond the constriction, but not reaching the tip. Anther with short erect point, hardly as high as rostellum. Pollinia 2, each longitudinally furrowed. Caudicle of medium length. Lateral appendages falcate with blunt tip and rather narrow basal lobe, nearly as high as rostellum; adnate to the base of the stigmatic-plate below the stigma. Stigma reniform.

\section{Sandergrove; Bridgewater; also Victoria (Grampians). Late Oct.-Nov.}

5. P. constrictum (referring to lateral constriction of labellum), Rogers. A slender species about $30 \mathrm{~cm}$. high. Leaf-lamina about as high as the spike. Flowers sessile, prune-colored, in a rather crowded spike. Dorsal sepal broadly lanceolate, very acute, concave, incurved over anther, about $7 \mathrm{~mm}$. long; lateral sepals stout, united to their middle, markedly bidentate, about $8 \mathrm{~mm}$. long. Petals rather spreading, lanceolate, about $6 \frac{1}{2} \mathrm{~mm}$. long. Labellum sessile or practically so, prune-colored, nearly $6 \mathrm{~mm}$. long; recurved (but not abruptly so) rather beyond the middle; erect part ovate or oval, not bulging, with entire margins; recurved part suddenly constricted at the bend and ending in an acute tip; callous portion not exceeding the membranous and not conspicuously 
thickened in the erect part, becoming increasingly thickened as it crosses the constriction and ending very abruptly near the tip. Anther without a point, nearly as high as rostellum. Rostellum with a conspicuous disk, bifid when the disk is removed. Caudicle rather short. Lateral appendages same height as anther, widely linear with obliquely truncate or slightly emarginate tips, basal lobes rounded reaching to about the middle; not adnate to the sides of the stigmatic plate. Stigma large reniform.

Tailem Bend. Early Oct.

6. P. odoratum (fragrant), Rogers. (Pl. 6, iii., figs. 6-9.) Usually tall and robust, $30-90 \mathrm{~cm}$. high. Leaf-lamina of varying length, often exceeding the spike. Flowers pink and white, strongly perfumed. Dorsal sepal about $10 \mathrm{~mm}$. long, ovate-lanceolate, often much recurved in old flowers, incurved in younger ones; lateral sepals about same length, dilated at the base, with conical points, very divergent. Petals rather shorter, pinkish with white tips or white with brownish strips, linear-lanceolate. Labellum as long as the sepals, conspicuously white, sessile or nearly sessile, oblong-lanceolate, acutely reflexed about the middle, tip looking between the lateral sepals; erect part rather bulging, margins entire; reflexed part bluntly triangular with very crenulated margins ; lamina with large pyramidal green callus at its base; the callous plate (fig. $7, c p l$.) not very thick in the erect part but more prominent towards its termination just beyond the bend; membranous portion very voluminous and exceeding the callus. Anther much shorter than rostellum. Rostellum elongated, triangular, rather higher than the lateral appendages (fig. 8, ap.). Pollinia 2, large, each markedly bilobed. Caudicle (fig. 8, cd.) linear about as long as anther. Lateral appendages falcate with rounded basal lobe, rather shorter than rostellum, adnate to the entire sides of the stigmatic-plate and slightly to the base of the stigma itself. Stigma reniform.

N.P. Widely but not numerously distributed throughout the State; also in Victoria. Nov.

Var. album, Rogers. A smaller plant with smaller flowers than the type, and with fewer pink tints, otherwise with similar coloring. The flowers in this State are not perfumed. The flexion of the labellum is seldom so acute as in the species and the reflexed part is usually shorter than the erect part.

Victor Harbor; Grunthal; Kadina; Yorke Peninsula; also Victoria. Sept-Nov.

7. P. rotundiflorum (round-flowered), Rogers. A slender species, about $18 \mathrm{~cm}$. high. Flowers yellowish-white; presenting a somewhat globular appearance, owing to the tendency for sepals and petals to converge at their tips to a point. Perianth-segments of equal length. Dorsal sepal concave, acuminate, about $8 \mathrm{~mm}$. long; lateral sepals free, lanceolate, curving upwards on each side of the labellum, yellowish-green. Petals bluntly linear, white with pinkish central stripe, incurved. Labellum on a short claw, bulging at the base; acutely reflexed about the middle; apex protruding between the sepals; white with large crisped membranous portion; callous part relatively small and not very thick, extending only a short distance beyond the bend. Column prune-colored. Anther very much shorter than rostellum. Caudicle long, about half the lergth of the pollinia. Lateral appendages narrowly lanceolate, very acute, about as high as rostellum, with a short basal lobe and a curved linear intermediate lobe. Rostellum very long, narrow, erect.

Cherry Gardens. Early Oct.

8. P. patens (spreading, referring to perianth-segments), R.Br. Slender, usually 10-30 cm. high. Flowers generally green, greenish, or brownish; sessile or almost so ; ovary turgid but less so than in $P$. fuscum, and not outstanding from the axis of the spike as in that species. Dorsal sepal rather less than $8 \mathrm{~mm}$. long, ovate-lanceolate, generally moderately recurved in the mature flower; lateral sepals about $8 \mathrm{~mm}$. long, free, lanceolate, generally slightly bidentate, not inflated at the base, almost parallel. Petals less than $6 \mathrm{~mm}$. long, linear, spreading. Labellum almost sessile, ovate-lanceolate, varying in degree of flexion but not abruptly bent; margins crenate or crenulate ; membranous border often whitish (but never pure white), greenish-yellow or light prune, greater in extent than callous portion, but not markedly so; the callous plate never very prominent and terminating some distance from the tip but well beyond the bend. Anther dark-brown, with very short point, much shorter than rostellum. Pollinia 2, of usual form and attachment. Caudicle of medium length, linear, attached to a narrow triangular disk. Lateral appendages narrow-oblong with smooth blunt or notched tips and small rounded basal lobe, shorter than the rostellum, only adnate at their extreme base to the sides of the stigmatic-plate. Rostellum erect, not very long, bifid after removal of disk. Stigma reniform.

N.P.; widely distributed on plains, hills, and Kangaroo Island; also in all the Eastern States. Sept.-Nov.

Var. pruinosum, Rogers. Flowers prune-colored, not scented; lateral appendages with a long basal lobe.

N.P. ; and other parts of Mount Lofty Range. Oct-Early Nov. 
9. P. fuscum (dusky, referring to color of flowers in Tasmania and eastern States), R. Br. Of slender habit, $15-30 \mathrm{~cm}$. high. Flowers green, sometimes yellowish-green, standing well out from axis of spike; ovary turgid, relatively large in comparison with the rest of the Hower; spike not very crowded. Dorsal sepal nearly $6 \mathrm{~mm}$. long, ovatelanceolate, generally erect, rarely recurved ; lateral sepals rather longer, about $6 \frac{1}{2} \mathrm{~mm}$., quite free, parallel, lanceolate, with usually cylindrical bidentate points. Petals about $4 \frac{1}{2} \mathrm{~mm}$. long, bluntly linear, erect. Labellum sessile, ovate-cuneate, recurved very nearly at a right angle about the middle; erect part bulging with entire margins; recurved part acute with crisped margins; callous plate occupying relatively large part of the lamina, not well marked near the base, increasing in thickness beyond the bend, and almost reaching to the extreme tip; lamina with a tooth-like lanceolate appendage reaching to the lower border of the stigma. Anther erect, without a point, about same height as rostellum. Lateral appendages very wide and blunt, oblong or almost quadrate, about as high as anther, free from stigmatic-plate, with relatively large basal lobes reaching beyond the middle. Stigma reniform just below the short rostellum.

N.P. ; widely distributed on plains, hills, and Kangaroo Island; also all Eastern States. Sept.-Oct.

10. P. Fitzgeraldii (after R. D. Fitzgerald, the well-known Australian Orchidologist), Rogers et Maiden. Usually stouter than the preceding species, $15-45 \mathrm{~cm}$. high. Flowers sessile or almost so, prevailing tints prune-color and green; very fragrant; standing well out from the vertical axis ; ovary turgid; expansion beginning in middle of spike, extending upwards and downwards. Dorsal sepal about $6 \mathrm{~mm}$. long, greenish, broadly lanceolate, flat, retracted, recurved at the very acute apex in mature flower; lateral sepals dull-green, free in mature flower, $6-6 \frac{1}{2} \mathrm{~mm}$. long, lanceolate. Petals green with dark-red longitudinal stripe, bluntly linear, about 4-5 mm. long, slightly divergent. Labellum prune-colored, sessile, slightly contracted at the base ; recurved almost at right angles about the middle; erect portion with entire margins, rather bulging; recurved portion broadly triangular with much crisped borders ; callous portion deep prune-colored, not very conspicuous in basal half, becoming more raised and pubescent at the bend and ending abruptly near the tip; membraneous part of lighter hue and rather smaller extent. Anther reddish-brown with rather blunt point, erect, but recurved after removal of the pollinia. Rostellum about same beight as lateral appendages and rather higher than anther. Pollinia 2, vertically bilobed. Caudicle rather short. Lateral appendages membranous, very wide, with truncate tips, quadrangular or almost so with basal lobe reaching to the middle, only adnate to the sides of stigmatic-plate at the extreme base. Stigma wide, almost rectangular.

N.P. ; and other parts of Mount Lofty Range. Sparsely distributed. October.

11. P. nigrieans (blackish), R. Br. A diminutive species $5-12 \mathrm{~cm}$. high ; arising from a globular tuber with succeeding season's tuber attached, tubers and base of stem invested in thick fibrous sheaths. Leaf-lamina at time of flowering reduced to a small sheathing bract near the inflorescence. Flowers on very short pedicels, minute, dark-purple (rarely green), deflexed, in a rather dense pyramidal spike, expanding uniformly from below upwards. Dorsal sepal rather broadly hood-shaped, erect, with short acute recurved tip, greenish or purple, about $2 \frac{1}{2} \mathrm{~mm}$. long; lateral sepals free except at their extreme base, about $3 \mathrm{~mm}$. long, green, cylindrico-lanceolate, widely diverging, not bulging much at base. Petals slightly shorter than dorsal sepal, about $2 \mathrm{~mm}$. long, triangular-lanceolate, purplish. Labellum dark-purple and very glandular, ahout as long as the dorsal sepal ; somewhat oblong but gradually widening from the base towards the apex, where it abruptly narrows to a short acute recurved tip; attached to the foot of column by a semicircular movable claw; margins minutely crenulate towards the tip, otherwise entire ; callous portion oblong, slightly raised, occupying more than half of the lamina, slightly channelled, reaching nearly to the apex; membranous part forming a rather narrow border round the callous plate. Anther incurved, the point at first soft, inflexed over the viscid disk, later hardening and becoming more vertical. Portion of column below the anther considerably longer than the anther itself. Pollinia 2, attached by a rather short caudicle to the ovate viscid disk of the rostellum; the latter rather shorter than the anther. Lateral appendages almost as long as the petals, bifid, the front claw longer than the back one : reaching to the level of the anther-point. Stigma oval.

N.P. ; and other parts of Mount Lofty Range; Myponga; Yankalilla; Victor Harbor; Millicent; Halbury; Yeelanna; Kangaroo Island; also in all eastern States and Tasmania. April.

12. P. fuscoviride (dusky-green), Reader. Habit, root and leaf as in the last species. Flowers minute green or yellowish-green, with dark-purple labellum, sessile, deflexed, in a rather crowded spike; their expansion usually occurring from below upwards, but often following a spiral course. Dorsal sepal about $3 \mathrm{~mm}$. long, green, widely lanceolate, concave, with recurved point; lateral sepals as long, green, free except at extreme base, lanceolate, widely diverging. Petals green with reddish central stripe, about $2 \mathrm{~mm}$. long, linear-lanceolate tipped with a small stalked gland. Labellum of variable shape, usually oblong-ovate, dark reddish-brown or purple, about $2 \mathrm{~mm}$. long, on a movable hinge ; tip 
slightly recurved but not nearly so much as in $P$. nigricans ; margins almost entire ; callous part reaching nearly to the tip, with a groove down the centre, equal in extent to the membranous part; latter unusually thick. Anther with extremely short point. Pollinia 2. Caudicle about as long as the pollen-masses. Rostellum equal in height to anther. Lateral appendages bifid, reddish-brown, triangular-lanceolate, higher than anther and rostellum.

Yorke Peninsula. Late April-Early May.

13. P. intricatum (intricate flowers), C. Stuart. Similar in habit, leaf and root to $P$. nigricans. Flowers on short pedicels, green or yellowish-green with pale-purple linear markings on the perianth-segments, or margins of latter edged with same color, labellum dark-purple, ovary rotund turgid, 2-6 in a somewhat squat spike. Dorsal sepal not very wide, nearly $4 \mathrm{~mm}$. long, tip very acute ; lateral sepals greenish, connate at base, lanceolatefalcate, very divergent, not bulging, concave on inner sides, a little over $4 \mathrm{~mm}$. long. Petals narrowly ovate-falcate, yellowish with 3 purple stripes and more or less purple margins, spreading and recurved, same length as dorsal sepal. Labellum on a semicircular claw; broadly ovate or oblong-ovate with markedly recurved tip; about same length as dorsal sepal; margins entire or slightly crenulate; the anterior half fringed with rather short hairs; callous portion wide, triangular, cleft posteriorly, reaching to tip or nearly so. Anther with very short point or pointless, higher than lateral appendages and rostellum. Pollinia 2, attached by caudicle of medium length to a prominent purple disk. Lateral appendages wide, bifid, ciliate along the upper half of their outer borders. Stigma oval, concave. Rostellum very viscid, reaching only a little above the base of the anther.

Mount Compass; also in Tasmania; Victoria; New South Wales. April-May. In the other States the flowers are usually of a dark-purple color.

\section{CALEANA, R. Br.}

(After G. Caley, a collector of New South Wales plants.)

Flowers reversed. Perianth-segments linear; the dorsal sepal slightly incurved behind the column; the lateral ones erect, spreading, or reflexed; the petals erect or incurved against the sides of the column. Labellum articulate on a movable claw with the base or foot of the column; the lamina peltate, ovate, its surface convex, smooth or tuberculate. Column elongated, its margins broadly winged throughout their length. Anther valvate, 2-celled, a pair of pollen-masses in each cell, pollen granular. Caudicle and viscid disk absent.-Terrestrial glabrous slender herbs, with 2 oval or elongated tubers. Leaf solitary radical, linear or narrow-lanceolate. Flowers usually 1-3 on slender pedicels.

The genus is represented by 4 known species and is limited to Australia and New Zealand, 1 species being common to both.

Lateral sepals and claw of labellum inserted at the base of the column; surface of labellum quite smooth ........ C. major 1.

Lateral sepals and claw of labellum inserted at the end of a foot or basal projection of the column; surface of labellum

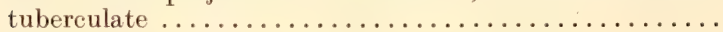

C. minor 2.

1. C. major (the larger Caleana), R. Br. (Text fig. 34, C.) Slender, glabrous, $15-30 \mathrm{~cm}$. high. Leaf radical, solitary, glabrous, narrow-lanceolate, generally reddish, about 5-8 $\mathrm{cm}$. long. Stem green or reddish-brown, wiry. Flowers reversed, reddish-brown, 1 or 2 on very slender pedicels, the upper flower-bract including a floral rudiment. Dorsal sepal linear-spathulate, acuminate on a contracted base, erect or incurved, channelled, about $12 \mathrm{~mm}$. long; lateral sepals slightly longer, reflexed, channelled, slightly divergent, contracted about the middle, then narrowly tubular or pointed. Petals narrow-linear, erect against wings of the column, about 9-10 $\mathrm{mm}$. long. Labellum attached to base of column by a long semicircular strap-like claw $5-6 \mathrm{~mm}$. long; lamina obovate, peltate on the claw, 8-9 mm. long, smooth, centre inflated and hollow, cavity open below, produced on the columnar side into a beak-like process, and into a flattened blunt appendage at the other end. Column incurved; very broadly winged from anther to base; wings slightly adnate to claw of labellum. Anther erect, not pointed. Stigma circular, prominent, concave. Pollinia free, a pair in each cell, elongated, laminate. No caudicle or viscid disk. Rostellum rudimentary.

Mount Lofty Range; sparsely distributed; also in all the Eastern States and Tasmania. Nov.-Dec.

2. C. minor (the lesser Caleana), R. Br. Slender, glabrous, $7-18 \mathrm{~cm}$. high. Leaf solitary, glabrous, reddish-brown, narrow-linear, $4-9 \mathrm{~cm}$. long. Stem wiry. Flowers smaller than in $C$. major, reversed, 1-6, reddish-brown, more rarely greenish, on slender pedicels, a floral rudiment within the uppermost bract. Dorsal sepal linear-spathulate, erect or slightly incurved, about $8 \mathrm{~mm}$. long; lateral sepals free, linear-lanceolate, channelled on inner surface, erect, arising nearly at right angles from the end of the columnar-foot, about $7 \mathrm{~mm}$. long. Petals narrower than the other segments, almost filiform, erect or 
incurved against the wings of the column, about $6 \frac{1}{2} \mathrm{~mm}$. long. Labellum peltate, attached by a rather long irritable semicircular claw to the extremity of the column-foot; lamina ovate, about $6 \mathrm{~mm}$. long, centre inflated and hollow, apex prolonged into a bifid glandulartipped process, the base into a short triangular point with a short spur on each side of the claw; upper surface convex, densely tuberculate, except near its extreme base, under-surface non-tuberculate concave, lateral margins also tuberculate. Column almost as long as the petals; its base extended into a foot about $3 \mathrm{~mm}$. long; widely winged throughout from anther to free end of foot. Anther 2-celled, very blunt, valvate. Pol linia 4, free, elongated, lamellate, granular or mealy. Stigma standing out prominently below anther, concave, viscid. Rostellum rudimentary. No caudicle or viscid disk.

Longwood and Kuitpo Forest; also all Eastern States and Tasmania. Dec.

\section{CORYSANTHES, R. Br.}

(Greek korys, a helmet; anthos, a flower.)

Dorsal sepal large, erect, incurved, hood-shaped; lateral sepals and petals diminutive, linear. Labellum large, tubular, its base erect enclosing the column; expanded towards the orifice; the expanded portion reflexed or recurved. Column short, fleshy, erect. Anther 2-celled, erect, valvate. Pollinia 4, in 2 pairs, attached directly to the viscid disk of the rostellum without the intervention of a caudicle; granular or mealy.-Dwarf terrestrial herbs arising from small rounded tubers; leaf single, ovate-cordate or rotund, with scarious sheathing bract below it. Flower relatively large, solitary, sessile or pedicellate. Pedicel elongated in the fruiting stage.

A rather extensive genus comprising upwards of 40 valid species, ranging as far north as the Philippines, extending westward to the Himalayas, traceable through the Indian Archipelago to New Guinea, where it appears to have its maximum distribution (19 species); also reported from islands of the Polynesian group and from New Zealand (8 species); represented in Australia by 4 or 5 species.

Dorsal sepal abruptly contracted into a narrow claw almost the same length as the orbicular lamina; orifice of labellum looking downwards, slightly contracted.......

Dorsal sepal gradually contracted towards the base. Orifice of labellum looking forwards, widely expanded.

Hood broad, dark-colored, projecting beyond labellum; margin of orifice of labellum deeply denticulate......

Hood narrow, especially towards the base, greyishgreen; not projecting beyond labellum; margins of labellar orifice hardly or only slightly denticulate ....

\section{C. unguiculata 1 .}

C. fimbriata 2.

C. pruinosa 3 .

1. C. unguiculata (clawed), referring to the base of the dorsal sepal), R. Br. Probably the smallest Australian member of the genus, sometimes not exceeding 10 or $12 \mathrm{~mm}$. high. Leaf ovate-cordate, often with a tendency to become 3-lobed; undersurface generally pale-red streaked with grey, $1-3 \mathrm{~cm}$. long. Flower single, pedicellate, reddishpurple, recurved or reflexed against a rather long ovary about equal in length to the pedicel. Dorsal sepal reddish-purple, $8-10 \mathrm{~mm}$. long, suddenly contracted into a narrow claw about $5 \mathrm{~mm}$. long; claw erect at base, then much incurved; lamina orbicular, concave, about 5 or $6 \mathrm{~mm}$. in diameter. Lateral sepals colorless, narrow-linear, $4 \frac{1}{2}-5 \frac{1}{2} \mathrm{~mm}$. long, spreading below the labellum. Petals much shorter, about $2 \frac{1}{2}-3 \mathrm{~mm}$. long, colorless, very narrow-linear, generally chelate, spreading on each side of the labellum. Labellum somewhat exceeding the dorsal sepal in length; tubular, inflated in the middle and diminishing in calibre from that part towards the base and towards the orifice; the lateral margins meeting along the dorsum in the middle line; the orifice oblique, directed downwards and forwards, margins entire or almost so; a longitudinal tract of calli extending almost from the orifice along the middle of the lamina nearly to the extreme base. Column very short, incurved, 2-winged. Anther 2-celled, valvate. Pollinia 4 , in 2 pairs; no caudicle. Stigma very prominent, large, circular.

Between Mount Gambier and Glencoe; also New South Wales ; Victoria ; and Tasmania. July-Aug.

2. C. fimbriata (fringed, referring to the labellum), R. Br. (Pl. 7, ii., figs. 7-9.) A larger and more robust plant than the last, attaining a height of $1 \frac{1}{2}-4 \mathrm{~cm}$. Leaf orbicularcordate, apiculate, with tendency to become 3-lobed, frosty on under-surface, usually $1 \frac{1}{2}-3 \mathrm{~cm}$. long, with a circular marginal vein. Flower large, 18-20 mm. long (without ovary), reddish-purple, sessile or almost so ; ovary terete, 5-6 mm. long. Dorsal sepal at first erect, then incurved, about $18 \mathrm{~mm}$. long, gradually contracted into rather a long claw; its lamina very blunt, broad and concave, almost horizontal, forming a hood projecting over and beyond the labellum. Lateral sepals colorless, linear, acuminate, about $4 \mathrm{~mm}$. long; connate at their bases with each other and also with the petals; directed more or less horizontally forward. Petals wider and shorter, narrow falcolanceolate, about $2 \mathrm{~mm}$. long, colorless, frequently bidentate, assuming variable positions but chiefly directed forwards. Labellum large, crimson, sessile, its lower half vertical 
against the dorsal sepal, enclosing the column in a split tube of gradually increasing calibre ; upper part acuitely recurved, expanded into a trumpet-shaped orifice with more or less denticulate margins and directed forwards; lamina with a large convex smooth white boss in the centre of the reflexed part and a band of short reddish hairs or calli in front of the boss, the remaining surface quite smooth; at the base the tube dilated at each side of its attachment into a wide auricle, the orifices of which open downwards. Column short, not winged, with prominent wide fleshy shield-like base. Pollinia 4, in 2 pairs, attached without a caudicle to a large viscid disk of the rostellum. Stigma reniform.

N.P. and other parts of Mount Lofty Range ; Millicent; Mount Gambier district; Kangaroo Island ; also from all parts of Commonwealth except N. Territory. June-July.

3. C. pruinosa (a "bloom," referring to the greyish color of the dorsal sepal), R. Cunn. Bearing a close affinity to the last species, of which it may possibly be a variety. A smaller flower than $C$. fimbriata; with a relatively narrower, shorter, and less obtuse hood, of a greyish or ashen color, not projecting beyond the front of the labellum ; the orifice of the labellum scarcely at all fimbriate, its margins having a tendency to curl inwards; the recurved part of the labellum diverging away from the erect part; separated apparently by no other constant features.

N.P. and other parts of Mount Lofty Range; also from all the Eastern States and Tasmania. June-Aug.

\section{ACIANTHUS, R. Br.}

(Greek akis, a point ; anthos, flower.)

Dorsal sepal erect or incurved over the column, concave, not very broad and often produced into a fine point ; lateral sepals narrow, spreading or upwardly curved. Petals much shorter, reflexed or spreading. . Labellum sessile, undivided, spreading, with 2 basal calli or tubercles (Pl. 7, i., figs. 1, 3, cal.). Column semitrete, incurved or inflexed, rarely winged. Anther broad, erect, 2-celled, valvate. Pollen granular or mealy. Pollinia 4, 2 masses in each cell, each pair connected to a separate disk of the rostellum without the intervention of a caudicle. Terrestrial glabrous herbs, with small rounded tubers. Leaf solitary, immediately above the basal scarious sheath or higher up the stem, broadly ovate-cordate, entire, lobed or rarely deeply dissected. Flowers usually in a terminal raceme, occasionally solitary, on a scape or stem without scales above the leaf, except the small bracts subtending the pedicels.

In addition to 5 Australian species, another occurs in New Zealand and 12 more in New Caledonia and Isle of Pines, making a total of 18 valid species.

Flowers 1-4; dorsal sepal narrow. with a filiform point from $2-3 \frac{1}{2} \mathrm{~cm}$. long $\ldots \ldots \ldots \ldots \ldots \ldots \ldots \ldots \ldots \ldots \ldots \ldots \ldots \ldots \ldots \ldots \ldots$.

Flowers usually upwards of 3 ; dorsal sepal ovate-lanceolate
with a point not exceeding $4 \mathrm{~mm}$. long $\ldots \ldots \ldots \ldots \ldots$

1. caudatus 1 .

A. exsertus 2.

1. A. caudatus (tailed, referring to the dorsal sepal), R. Br.(Pl. 7, i., figs. 1-6). Very slender, glabrous, $7-15 \mathrm{~cm}$. high. Leaf radical or nearly so; cordate-ovate, rather thin ; margins entire, crenate or sometimes more or less lobed; green above, reddish below, reticulate, rarely exceeding $2 \frac{1}{2} \mathrm{~cm}$. long. Flowers $1-4$, crimson; on short pedicels. Dorsal sepal more or less inflexed, dilated rather narrowly over the anther, then tapering into a filiform point $2-3 \frac{1}{2} \mathrm{~cm}$. long; the dilated part concave on a contracted base, $5.6 \mathrm{~mm}$. long. Lateral sepals free, much shorter than the dorsal sepal, about $15 \mathrm{~mm}$. long, tapering into fine points curving upwards at their ends. Petals falco-lanceolate, reflexed or spreading, 1.i) $\mathrm{mm}$. long. Labellum sessile, crimson like the other parts ; base erect, semiorbicular, embracing the column ; thereafter broadly but very acutely lanceolate, at first horizontal then abruptly recurved near the tip; the margins entire ; lamina glandular with smooth surface, except for 2 tooth-like or triangular calli (cal., figs. 1, 3) at the extreme base. Column about $4 \mathrm{~mm}$. long, inflexed on the summit of the ovary; almost terete in its lower two-thirds, dilated above, very narrowly winged in the terete part, widening shortly on each side of the stigma and continued upwards as a kind of arillus behind the anther. Anther pointless. Pollinia 2 in each cell, granular, each pair connected to a separate viscid disk in the upper border of stigma. Stigma rather prominent, hemispherical. Rostellum double; each part tooth-like, bearing a relatively large viscid disk.

Rather rare. Mount Lofty Range; Dingabledinga; Delamere; Victor Harbor ; Beetaloo; Kangaroo Island; also New South Wales; Victoria; Tasmania. Sep.-Oct.

2. A. exsertus (protruded, referring to the bending forwards of the column), $\mathrm{R}$. $\mathrm{Br}$, Slender, glabrous, $7-16 \mathrm{~cm}$. high. Leaf single, sessile, ovate-cordate; generally a little above the base; green above, red below; margins entire, often sinuous; one or two marginal nerves, venation otherwise reticulate. Flowers 3-20, on short pedicels, in a raceme, reddish-purple or rarely verdant-green. Dorsal sepal about 5 or $6 \mathrm{~mm}$. long, concave, slightly incurved, much contracted below, expanded above and terminating in a fine short point; lateral sepals almost as long, subulate, free, spreading beneath the labellum. Petals lanceolate, $2-3 \mathrm{~mm}$. long, acutely bent backwards. Labellum ovate- 


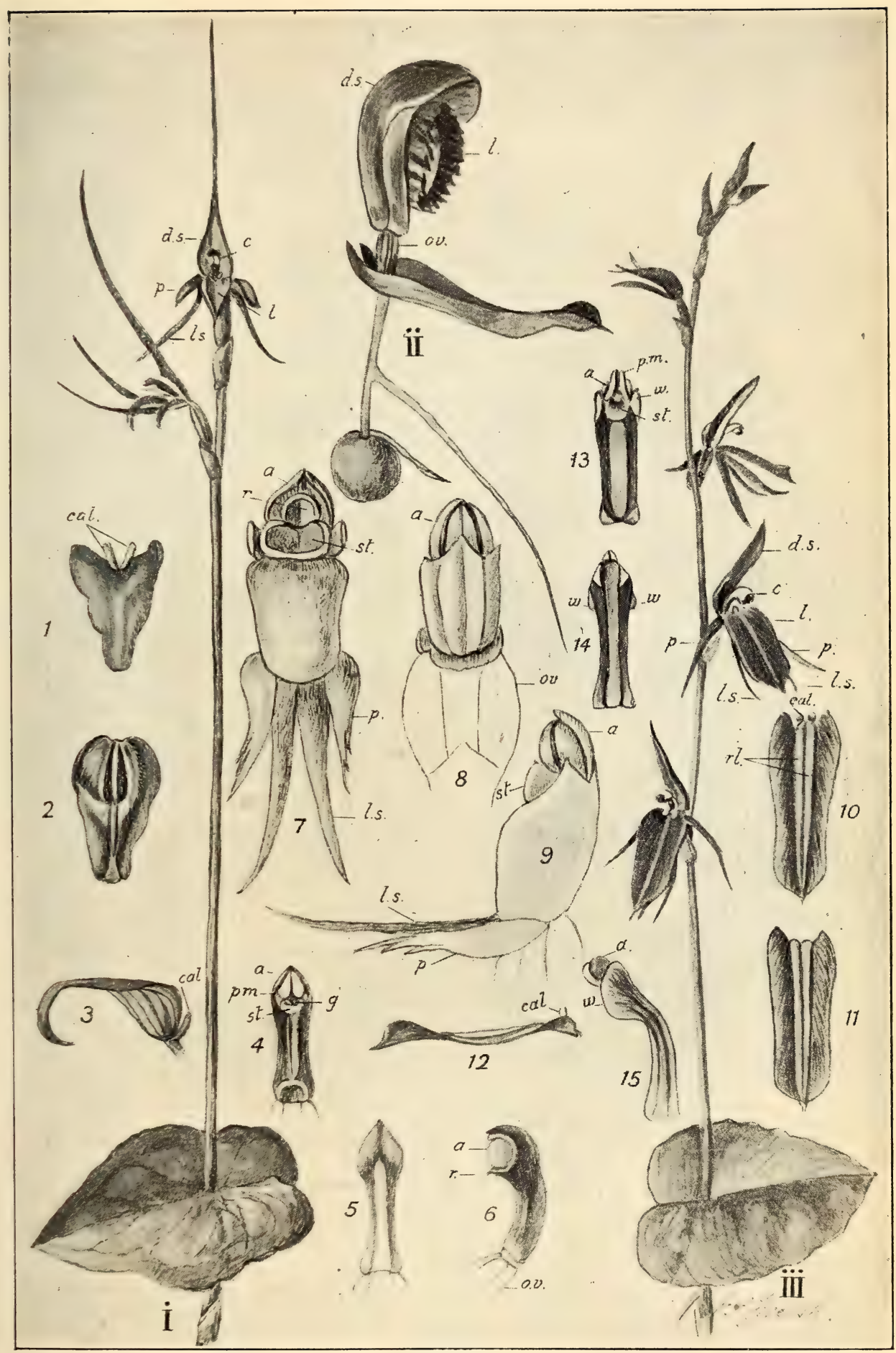

Plate 7.

i. Acianthus caudatus, plant nat. size. Fig. 1.- Labellum from above; cal., calli at the base. Fig. 2.Same from below. Fig. 3.- Same from side. Fig. 4.- Column from front. Fig. 5.- Same from back.
Fig. 6.-Same from side. All details enlarged.

ii. Corysanthes fimbriata. plant nat. size. Fig. 7.-Column, lateral sepals, and petals from front. Fix. 8.

iii. Column from back. Fig. 9 - Column, sepals, and petals from side. Details greatly enlarged.

Cyrtostylis reniformis, plant nat. size. Fig. 10.- Labellum from top; cai., 2 calli at base ; r.l., raised
lines. Fí. 11.-Same from below. Fig, 12, - Same from side. Fig. 13. - Column from front. Fig. 14. - Same from back. Fig. 15.--Same from side. Details enlarged. 
lanceolate with a very acute depressed point; on a short claw or contracted base; generally a deeper red than the perianth-segments; spreading; about $3 \mathrm{~mm}$. long; margins entire : lamina smooth except for a pair of prominent basal glands. Column semiterete, enlarged at each end, upper end cup-shaped, about $2 \frac{1}{2} \mathrm{~mm}$. long, very much incurved above. Anther quite blunt on a sunken clinandrium. Pollinia 2 in each cell; each mass semicircular with clavate ends like a dumb-bell, each pair connected by their middle to a separate viscid disk. Stigma transverse, oval, prominent, very concave. Rostellum double, represented by a tooth-like prominence at each end of the upper border of the stigma, each bearing a separate viscid disk.

N.P. and other parts of Mount Lofty Range ; Victor Harbor ; Bordertown ; Millicent; Delamere ; Golden Grove ; Beetaloo; Kangaroo Island ; also in all other States of the Commonwealth. May-July.

\section{CYRTOSTYLIS, R. Br.}

(Greek kyrtos, curved ; stylos, a column.)

Dorsal sepal narrow-lanceolate, erect, incurved, concave. Lateral sepals and petals very narrow, spreading, nearly equal in length to the dorsal sepal or the petals a little shorter. Labellum sessile, flat, undivided, entire, contracted at its insertion, with 2 calli (Plate 7, iii., figs. 10, 12, cal.) at the base produced into raised lines (fig. 10, rl.) along the lamina. Column elongated, incurved, winged in its upper part. Anther terminal, erect, 2-celled. Pollinia 4, a pair in each cell, powdery. Rostellum situated centrally in the upper border of the stigma with a viscid disk on each side of it. No caudicle present. Terrestrial glabrous herbs. Leaf solitary, sessile at the base of the stem, lamina broad and spreading. Scape without any empty bract, usually bearing a raceme of several flowers.

A small genus, containing but 2 valid species, one of which is widely distributed throughout Australia, and the other is a native of New Zealand. A variety of the latter was formerly given the status of a species.

1. C. reniformis (lidney-shaped, referring to the leaf), R. Br. A slender plant, 7-15 cm. high, with the characters of the genus. Leaf orbicular-cordate, $2-3 \frac{1}{3} \mathrm{~cm}$. long, green on both sides. Flowers generally $3-6$, but sometimes solitary, reddish-brown, rarely verdantgreen, sessile or on very short pedicels. Dorsal sepal about $10 \mathrm{~mm}$. long; lateral sepals about $9 \frac{1}{2} \mathrm{~mm}$.; petals narrower than latter but same length. Labelium as long as the dorsal sepal and about $4 \frac{1}{2} \mathrm{~mm}$. wide. Column about $6 \mathrm{~mm}$. long, semiterete, dilated at each end. Anther (fig. 15, «.) rather globose without a point. Pollinia leg-of-mutton shape, each pair attached to a separate viscid disk.

N.P. : widely distributed throughout southern part of the State and as far north as Burra; also Kangaroo Island and Hundred of Goyder. It occurs in every other State of the Commonwealth. July-Aug.

\section{LYPERANTHUS, R. Br.}

(Greek lyperos, mournful ; anthos, flower ; referring to the gloomy color.)

Dorsal sepal usually broad, erect, or incurved over the column ; other segments narrow erect or spreading, about equal in length to the dorsal sepal. Labellum much shorter undivided or 3-lobed; lamina more or less papillose, sometimes bearing raised longitudinal lines. Column erect, incurved, more or less winged, as long or nearly as long as the labellum. Anther terminal, 2-celled. Pollina 4, or a bilobed mass in each cell granular or mealy.-Terestrial glabrous herbs, sometimes drying black, with small underground tubers. Leaves 1-3, usually at or near the base, broad and thick or long and narrow. Bracts often large and leaf-like.

A small genus comprising 12 known species, 5 of which are endemic to Australia, 1 to New Zealand, and 6 to New Caledonia.

1. L. nigricans (becoming black when dry). R. Br. (Text fig. 32, B.) A stout plant, $10-30 \mathrm{~cm}$. high, drying black. Leaf radical orbicular-cordate or broadly ovate-cordate, fleshy, of variable size, sometimes $10 \mathrm{~cm}$. long; stem-bracts usually 2, loose sheathing. leaf-like, rather blunt, often 3 or $4 \mathrm{~cm}$. long. Flowers large, 2-8, purple or with darkpurple stripes: ovary and pedicel included in a capacious bract which also envelopes the perianth. Dorsal sepal usually light-colored with purple stripes, broadly lanceolate, much incurved, often $2 \frac{1}{2} \mathrm{~cm}$. long. Lateral sepals spreading or deflexed, dark-purple, linear, free, same length as the dorsal one. Petals similar to lateral sepals, but recurved or spreading. Labellum lighter-colored with purple veins and dark tip, sessile, obovatelanceolate, about $15 \mathrm{~mm}$. long; 3-lobed; lateral lobes erect, clasping column; the middle one with rather blunt tip, much recurved, fringed or deeply denticulate ; lamina with a wide smooth longitudinal raised line or band between the lateral lobes; a few minute sessile white calli distributed towards the tip and lateral margins; a pex with a few similar calli on the under-surface. Column at first erect, then incurved, about $12 \mathrm{~mm}$. long, very narrowly winged. Anther terminal incumbent, with a rather blunt, fleshy point. Pollinia 2, elongated, each bilobed, very powdery, no attachment by 
caudicle or otherwise to rostellum. Stigma very prominent, circular or lobulate, its upper marein thickened into a convex rostellum in close contact with the bases of the pollinia.

N.P. and other parts Mount Lofty Range; Victor Harbor district; Bordertown; Nangkita; Golden Grove ; Yeelanna; Cummins ; Kangaroo Island ; also all the other States, except Queensland. Sept.-Oct.

\section{ERIOCHILUS, R. Br.}

(Greek erion, wool; kheilns, a lip).

Dorsal sepal erect, sligthly incurved, concave ; lateral sepals longer, spreading, elliptical, contracted into a distinct narrow stipes; petals nearly as long as dorsal sepal, usually narrower, erect or slightly spreading. Labellum much shorter, sessile, on a long erect narrow-oblong base, the margins often produced into erect lateral lobes; expanded and much recurved above, the terminal part very convex, entire, glandular-villous. Column erect, elongate, narrowly winged. Anther erect, blunt, valvate, 2-celled ; outer valves large, folded over and concealing the small inner valves. Pollinia 8, waxy or granular, 4 pyriform masses in each cell united below into a short acute common apex adherent on each side to a small viscid disk; the 2 disks situated close together on the upper border of the stigma.-Terrestrial glandular pubescent or hairy (rarely glabrous), herbs, originating from more or less globular underground tubers. Leaf glabrous, solitary, at the base or nearer the middle of the stem, ovate or lanceolate. Flowers pink or white, 1 or 2 , more rarely multiflowered in a spike or raceme, each subtended by a short loose ovate bract; no empty stem-bracts above the leaf.

A small genus with 5 known species, confined to Australia.

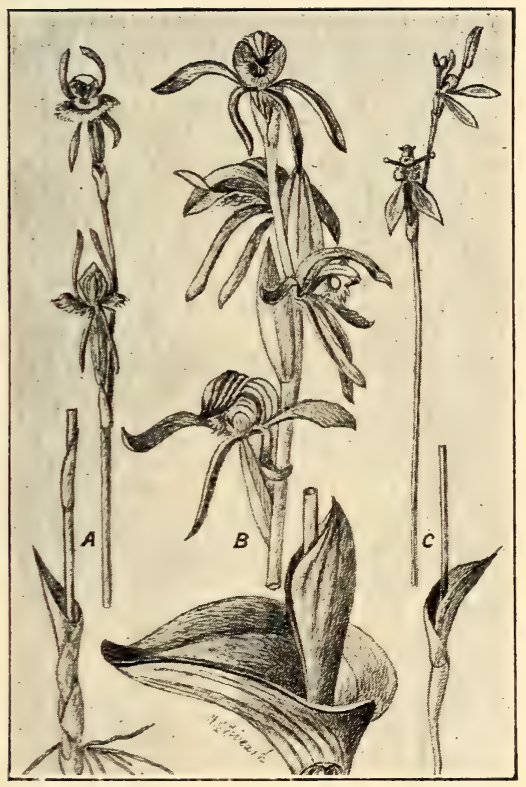

Text-figure 32.-A. Leptoceras fimbriata. B. Lyperanthus nigricans, showing intlores cence, basal leaf, and basal bract. C. Eriochilus autumnalis. All much reduced
1. E. autumnalis (autumnal), R. Br. Text fig. 32, C. Slender, 7-22 cm. high, with the characters of the genus. Leaf radical, ovate, arute, often small at time of flowering, continuing to develop in size thereafter. Flowers 1-3, pink and white. Dorsal sepal erect, 7-8 mm. long, spathulate, green or greenish-brown; lateral sepals 12-13 mm. long, white, elliptical-lanceolate. Petals erect, linear-falcate. Labellum about as long as petals, the erect part glahrous, often with minute lateral lobes; the recurved part much wider, ovate, with transverse ridges of reddish hairs. Column about $5 \frac{3}{4} \mathrm{~mm}$., with narrow wings below the stigma. Pollinia 8, lamellate, hard and waxy: an anterior and posterior pair in each anther-cell, the 2 pairs united by their apices into a common sharp point (or false-caudicle) which is adherent to the viscid disk on its own side of the antherseptum. Stigma rectangular or semicircular, very prominent and concave, situated just below the anther; viscid disks 2, on its upper border, close together on each side of the middle line. No definite rostellum.

N.P. and Mount Lofty Range, widely distributed in other parts of the State; also in all eastern States and Tasmania. April-May.

\section{LEPTOCERAS, Lindl.}

(Greek leptos, thin ; keras, horn, antenna ; referring to the petals).

Dorsal sepal wide, erect, incurved, acute, concave, contracted gradually towards the base ; lateral sepals about equal in length, acute, very narrow, deflexed against the ovary. Petals rather longer, erect, pointed, linear-clavate, the clubbed part very glandular. Lahellum on a short mosable claw, much wider than long, 3-lobed; the lateral lobes large and dome-shaped, fringed or deeply combed anteriorly, with pubescent spots on their upper convex surface ; the middle lobe much smaller, rounded, not recurved, less deeply combed, its upper surface smooth or almost so. Column incurved, rather widely winged. Anther bent forward, 2-celled, valvate. Pollinia 4, in 2 pairs, lamellate. Stigma triangular, its apex deeply sunk between the divergent lobes of the anther. Rostellum poorly developed; no viscid disk or caudicle.--Terrestrial glabrous herbs, originating from a rounded tuber with fibrous roots, Leaf basal, solitary (rarely 2), sessile, 
sheathing, ovate, oblong or broadly lanceolate, often small at the time of flowering, increasing in size thereafter and developing marked parallel veins.

Peculiar to Australia and consisting at present of only 1 species, but closely allied to C. Menziesii and the genus Eriochilus, which have been included under Leptoceras by some botanists. On the other hand the single member of this genus is commonly placed under Caladenia by taxonomists and is so included by Bentham.

1. L. fimbriata (fringed, referring to the labellum), Lindl. (Text fig. 32, A.) Very slender, $15-20 \mathrm{~cm}$. high, with the characters of the genus. Flowers 1-3, reddish or yellowish-brown, on slender pedicels, a floral rudiment included within the uppermost flower bract. Dorsal sepal about $9 \mathrm{~mm}$. long. Petals longer than the other segments about $11 \mathrm{~mm}$. Labellum greenish, with reddish-brown pubescent spots, about $9 \mathrm{~mm}$. wide and $5 \mathrm{~mm}$. long. Column $6-6 \frac{1}{2} \mathrm{~mm}$.-Caladenia fimbriata, Reichb. f.; Eriochilus fimbriatus, F. v. M.

Black Hill ; Golden Grove ; Dingabledinga ; Port Elliot; Inman Valley; Yankalilla ; Kuitpo; Mount Compass; Bordertown; Kangaroo Island; also Western Australia and Victoria. April-July.

\section{CALADENIA, R. Br.}

(Greek kalos, beautiful ; adèn, a gland.)

Dorsal sepal erect, incurved over the column or more rarely retracted, usually narrow ; lateral sepals nearly equal to it, but flat, spreading or reflexed. Petals narrow, erect, spreading or reflexed. Labellum often on a movable claw and generally erect at the base ; undivided or 3-lobed; the lateral lobes when present erect; the middle lobe or upper part of the undivided labellum recurved (Pl. 8, i., ii., fig. 6, ml.); the margins often fringed or toothed; the lamina with sessile or stalked calli (figs, 1, 2, 5, 6, cal.), arranged in 2 or more longitudinal rows or irregularly scattered or crowded. Column erect or incurved, more or less 2 -winged in the upper part (figs. 4, 7.). Anther terminal, more or less oblique, usually pointed, 2-celled, valvate. Pollinia 4, lamellar, commonly leg-of-mutton shape, 2 free masses in each cell, granular. Stigma immediately below the anther, circular and disk-like. Rostellum poorly developed. Viscid disk and caudicle absent.-Terrestrial herbs, generally very hairy, but sometimes only slightly so, originating from rounded tunicated tubers, the more recent tubers generally to be found below those of previous seasons. Leaf more or less hairy (except in C. Menziesii), solitary, elongate, generally linear-lanceolate or oblong, from within a scarious sheathing scale close to the ground. Flowers solitary, or in a loose raceme or panicle of (apparently) not more than 6 , on an erect scape with an empty bract or sheathing scale about the middle and a similar bract under each pedicel; in one species both leaf and bract are absent at time of flowering; flowers usually erect and variously colored. The species with long-tailed sepals are commonly known as Spider Orchids.

A rather large genus comprising nearly 60 known species. Of these, 3 or 4 are reported from New Zealand and 54 from Australia. Of the latter all are endemic with the exception of one $(C$. carnea) which has been reported from Java. Curiously enough no records have been made from any of the islands intermediate between Java and Australia.

\section{Section 1.}

Flowers particolored, usually in shades of yellow, green, reddish-brown, or white. Lateral sepals elongate, $2-6 \mathrm{~cm}$. long, constricted into short acuminate or caudate points; petals not longer than sepals; two sessile yellow glands at base of column.

Margins of labellum entire or practically so ; flowers yellowish-green and reddish-brown.

Calli stalked; lateral sepals not produced into caudae. Calli in 2 rows; lateral sepals shortly acuminate...

Calli in 4 rows; lateral sepals contracted into bayonet-shaped points .................

Calli sessile except at extreme base of labellum ; lateral sepals caudate, clavate.

Labellum narrow-oblong or oblong-lanceolate ......

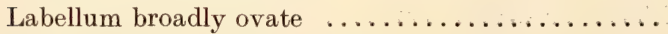

Margins of labellum definitely serrate or denticulate.

Denticulations on margin short.

Labellum obscurely 3-lobed or crescent-shaped; margins of lateral lobes only denticulate anteriorly ; lateral sepals shortly acuminate; flowers greenishyellow or reddish-brown $\quad \ldots \ldots \ldots \ldots \ldots \ldots \ldots$.

C. cardiochila 1 .

C. gladiolata 2.

C. leptochila 3.

C. ovata 4.

C. toxochila 5. 
Labellum undivided; tip only slightly denticulate, lateral margins much so; lateral sepals caudate.

Labellum with dark divergent veins; calli in 4 rows; lateral sepals about $3 \mathrm{~cm}$. , clavate, spreading rigidly; flowers crimson or reddish-

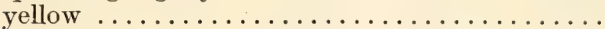

Labellum without conspicuous divergent veins; calli in 4-6 rows; lateral sepals usually much exceeding $3 \mathrm{~cm}$., not clavate, spreading but not rigidly so ; flowers usually cream with dark tips, rarely crimson, sometimes yellowish-green and

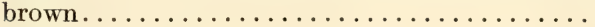

Denticulations near base of labellum produced into combings; labellum distinctly 3 -lobed; calli in 4 rows ; lateral sepals about $5 \mathrm{~cm}$., clavate, spreading ; flowers very large; yellow, green, and maroon......

C. reticulata 6 .

\section{Patersonii 7.}

C. dilatata 8 .

\section{Section 2.}

Flowers crimson or cream-colored. Lateral sepals elongate, 1.8-6 cm. long; contracted into caudate points; petals not longer than lateral sepals; no sessile yellow calli at base of column.

Calli in 2 rows, lateral sepals very long and filiform, often exceeding $6 \mathrm{~cm}$. ; flowers crimson in the type, creamcolored with brown veins in the variety...........

Calli in 2 rows ; lateral sepals hardly $2 \mathrm{~cm}$. long; flowers cream with reddish-brown veins $\ldots \ldots \ldots \ldots \ldots \ldots \ldots$.

C. filamentosa 9 .

C. bicalliata 10

\section{SeCtion 3.}

Flowers pink and white; petals erect, longer than the lateral sepals ; no sessile yellow calli at the base of column. Leaf glabrous; petals reddish, clavate; lateral sepals white, somewhat crescentic ...............

\section{Menziesii 11.}

\section{Section 4.}

Flowers pink, white, or blue; perianth-segments similar in shape and color; the upper one usually erect, others spreading, relatively much wider and shorter than in Sections 1 and 2, never produced into caudae or long points ; no sessile yellow calli at base of column.

Perianth-segments pink or white on upper surface.

Leaf more or less oblong, rather wide; labellum 3 -lobed, without transverse pink bands; calli in 2 short converging rows $\ldots \ldots \ldots \ldots \ldots \ldots \ldots \ldots$ Leaf narrow-linear; labellum 3-lobed.

Labellum with parallel transverse dark pink bands; calli linear in 2 parallel rows, none on tip........

Labellum without transverse bands; middle lobe long and narrow ; calli dark, fleshy, very crowded, sessile except at base, in 2 obscure rows reaching

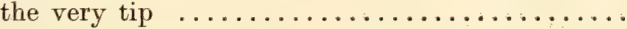

Labellum with indefinite lateral lobes; calli in 4 rows extending nearly to the extreme tip; perianth-segments darker on the outside than within $\ldots \ldots \ldots \ldots \ldots \ldots \ldots \ldots \ldots \ldots \ldots \ldots \ldots \ldots \ldots \ldots \ldots \ldots$

Perianth-segments blue or rarely white; leaf only very slightly hairy.

Labellum distinctly 3-lobed, not fringed, with darkblue parallel transverse bands; calli in 2 rows, extending well on to the tip; leaf linear..........

Labellum rather indefinitely divided, but 3 lobes present, fringed anteriorly; calli in 4-6 rather illdefined rows almost reaching the extreme tip; leaf

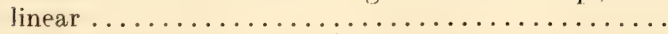

Iabellum undivided; not fringed; calli in 2 rows not extending to tip, with 4 tall calli fused or free at extreme base; leaf oblong $\ldots \ldots \ldots \ldots \ldots \ldots \ldots$.

\section{C. latifolia 12.}

C. carnea 13.

C. congesta 14 .

C. testacea 15 .

C. coerulex 16.

C. deformis 17 .

C tutelata 18. 
1. C. cardiochila (heart-shaped labellum), Tate. Slender, hairy, 15-22 cm. high. Leaf linear-lanceolate, hairy, $4-11 \mathrm{~cm}$. long. Flower single, rarely 2, on a slender pedicel. Segments of perianth brownish-red with yellow margins, or yellowish with brownish-red central streak, subequal. Dorsal sepal linear-lanceolate, erect, incurved, 15-20 mm. long; lateral sepals much wider, spreading, flat, falco-lanceolate, somewhat contracted at the base, dilated in the middle, then rather abruptly acuminate. Petals much narrower than lateral sepals, linear-lanceolate, spreading or depressed. Labellum on a narrow movable claw ; cordate or broadly ovate ; undivided, margin entire with a conspicuous dark-brown thickening round the apex; rather flat, usually erect at the base, thereafter spreading with depressed tip, in color reddish-brown or yellow with dark divergent veins ; lamina with 2 (rarely 4 ) rows of dark clavate fleshy crowded calli, its anterior third naked; about $10 \mathrm{~mm}$. long and $11 \mathrm{~mm}$. wide. Column retracted, then much incurved, about $11 \mathrm{~mm}$. long, widely winged in its upper two-thirds; 2 yellow sessile oval calli at the base.

Golden Grove; Yatala Vale; Halbury; Nuriootpa; Mount Lofty Range ; Robe ; Millicent; Kangaroo Island; also recorded from Victoria. Sept.-Oct.

2. C. gladiolata (bayonet-shaped, referring to the points of the sepals), Rogers. Rather stunted, hairy, $8-18 \mathrm{~cm}$. high. Leaf hairy, varying in shape and size from oblong-lanceolate to ovate-lanceolate. Flower single, rarely 2, greenish-yellow with red markings. Sepals similar, subequal, about $16-20 \mathrm{~mm}$. long and $2 \mathrm{~mm}$. in widest part, traversed by a longitudinal red line in lower two-thirds, thereafter constricted into a thickened reddishbrown glandular bayonet-shaped point; the dorsal one erect, incurved or retracted; the lateral ones spreading, flattened except at their extremities. Petals rather shorter, linear-lanceolate, about $14-16 \mathrm{~mm}$. long, spreading, with central reddish line, tips very glandular and similar to the sepals. Labellum ovate, about $9 \mathrm{~mm}$. long, on a movable claw, undivided, yellowish-green with maroon recurved tip; margins practically. entire, at first erect against the column, then recurved from about the middle ; lamina without conspicuous veinings, the calli large, fleshy, pyriform, dark reddish-brown, in 4 crowded rows and not extending to the tip. Column about $8 \mathrm{~mm}$. long, much incurved, with 2 yellow sessile calli at the base, widely winged in its upper part; wings tapering towards the base.

Hornsdale; near Appila-Yarrowie; Cherry Gardens. Sept.

3. C. leptochila (thin labellum), Fitzg. Slender, hairy, $15-45 \mathrm{~cm}$. high. Leaf very hairy, narrow-lanceolate to oblong or elliptical-lanceolate, sheathing at the base, lamina 4-14 cm. long. Flowers 1 or 2, large, prevailing tints yellowish-green and reddish-brown. Perianth-segments with a central reddish-brown stripe, spreading (with exception of the dorsal sepal); sepals clavate, subequal. Dorsal sepal incurved, $2 \frac{1}{2} \cdot 3 \mathrm{~cm}$. long, tapering from the base to a fine clavate point: lateral sepals dilated in basal half, thereafter constricted into fine upturned clavate points. Petals falco-lanceolate, gradually tapering into fine nun-clavate points, $2-2 \frac{1}{2} \mathrm{~cm}$. long. Labellum oblong or broadly lanceolate, 11-15 mm. long (including the claw) and $41 \mathrm{~mm}$. wide, on a distinct movable claw, undivided, dark reddish-brown, erect in lower half, thereafter recurved, margin practically entire, tip generally acute, sometimes blunt, lamina almost flat; calli sessile (except near the claw), in 4 rows, rarely extending beyond the bend. Column $10-12 \mathrm{~mm}$., retracted at base, thereafter erect or incurved, widely winged above, more narrowly below ; 2 sessile yellow calli at the base. Anther with straight sharp point.

N:P. and other parts of Mount Lofty Range; Wirrabara; Hornsdale ; Angaston ; Delamere; Bordertown; also Victoria. Oct.

4. C. ovata (onute labellum), Rogers. Slender, hairy, $10-23 \mathrm{~cm}$. high, Leaf very hairy, $3-7 \mathrm{~cm}$. long, narrow-lanceolate or oblong-lanceolate. Flowers usually solitary, occasionally 2, very rarely 3, large, reddish-yellow. Sepals with dark central stripe, dilated in their basal half thereafter contracted into very fine clavate caudae. Dorsal sepal $2-2 \frac{3}{4} \mathrm{~cm}$. long, erect or slightly incurved over column ; lateral ones rather longer, spreading. Petals shorter than sepals, lanceolate, nct clubbed, spreading. Labellum ovate on a short movable claw ; $9.10 \mathrm{~mm}$. long (without the claw) and $8 \mathrm{~mm}$. wide; reddish-yellow with dark-red tip, moderately recurved from about the middle, margin entire, lamina with dark divergent veins; the calli extending to about the bend, but very inconstant, in 2 or 4 rows, sometimes represented by a few minute irregularly placed bossings, occasionally entirely absent, generally small mammillary except for a few short clavate ones near the claw. Column about $8 \mathrm{~mm}$. long, rather incurved, more winged in its upper than lower half ; 2 yellow sessile calli at the base.

Abundant along south coast of Kangaroo Island from Wilson River to Eleanor River. Sept.-Oet.

5. C. toxochila (bow-lipped), Tate. Rather dwarf, hairy, 12-30 cm. high. Leaves slightly hairy, oblong, $6-15 \mathrm{~cm}$. long and $5-20 \mathrm{~mm}$. wide. Flowers solitary or rarely 2, prevailing tints yellow, green, and maroon. Perianth-segments generally yellowishgreen, with maroon stripe down centre; the sepals acuminate and usually slightly clavate. Dorsal sepal erect, incurved, narrower and rather shorter than the others, about $2 \mathrm{~cm}$. 
long, concave, tip glandular; lateral sepals spreading, flat, lanceolate, about $2 \cdot 2 \mathrm{~cm}$. long with minutely glandular tips. Petals shorter and narrower, about $1.8 \mathrm{~cm}$. long, not clubbed, lanceolate, deflexed or spreading. Labellum on a rather long and movable claw ; about $9 \mathrm{~mm}$. long (extended) and $10 \mathrm{~mm}$. wide ; crescent-shaped in the typical form with a broad apical extension ; the apex short, maroon, recurved ; anterior margin fringed with narrow short denticulations; lamina behind the tip greenish-yellow, sometimes with conspicuous divergent veins; calli on long stalks with fleshy heads, marooncolored, in 4 obscure rows along the centre but not extending to the apical portion. Column about $10 \mathrm{~mm}$. long, much incurved, broadly winged in upper two-thirds; 2 yellow sessile calli at the base.

Caroona Hill, near Iron Knob; Crystal Brook. Aug.-Sept.

6. C. reticulata (netted, referring to the dark red veins on labellum), Fitzg. Slender, hairy, 10-30 cm. high. Leaf very hairy, generally linear or narrow-lanceolate, channelled, about $4.8 \mathrm{~cm}$. long. Flowers large, usually single, rarely 2, prevailing tints yellowish. green and crimson, sometimes wholly crimson. Sepals yellowish-green with red central stripe, clavate, of equal length. Dorsal sepal erect, incurved, about $2.7 \mathrm{~cm}$. long, dilated in basal half, thereafter contracted into a filamentous clavate point; lateral ones similar, but rigidly spreading. Petals lanceolate, usually darker, shorter, and narrower, not clubbed, spreading, with crimson stripe, gradually narrowing from the base to a fine point. Labellum on a distinct movable claw; crimson or crimson and yellow, ovate, $12.13 \mathrm{~mm}$. long; lower half erect with dentate margins; recurved part rather acute, only slightly denticulate; calli fleshy, crimson, of the golf-stick type, hardly extending beyond the bend ; lamina smooth at the tip, generally with dark crimson veins, the latter sometimes inconspicuous. Column retracted at the base, thereafter erect and incurved; $9.10 \mathrm{~mm}$. high ; widely winged above, more narrowly below ; 2 sessile yellow calli at the base. Anther with straight sharp point.

N.P. and other parts of Mount Lofty Range ; Bordertown ; Robe ; Millicent ; Nangkita; Mount Compass; Beetaloo; Kangaroo Island; also Victoria. Oct.

7. C. Patersonii (after Col. Wm. Paterson, Lt.-Governor of New South Wales and Tasmania), R. Br. A hairy species $20-30 \mathrm{~cm}$. high. Leaf hairy, oblong to linear-lanceolate, sometimes quite short but often exceeding $15 \mathrm{~cm}$. long. Flowers large, usually solitary, occasionally 2 or 3 , generally white or creamy with dark points on perianthsegments and labellum, more rarely crimson or yellow, sometimes yellowish-green and brown, often $10-15 \mathrm{~cm}$. in diameter. Perianth-segments all spreading, except dorsal sepal, with points dark and glandular-hairy, but not clavate. Dorsal sepal erect or incurved over the column, the portion behind the column dilated, thereafter produced into a long tentacular point, usually $4 \frac{1}{2}-6 \mathrm{~cm}$. long; lateral sepals similar but spreading and drooping, rather longer, with a wider and longer dilated portion. Petals shorter than dorsal sepal, $4-5 \frac{1}{2} \mathrm{~cm}$. long gradually tapering to fine points. Labellum $1 \frac{1}{2}-2 \mathrm{~cm}$. long (extended), usually with purple or crimson tip and calli ; ovate-lanceolate on a short claw; undivided; the basal half commonly light-colored, erect, with acutely toothed margins, anterior portion recurved, generally purple or crimson. the margins bluntly toothed or serrate with acute tip; calli of lamina rarely extending beyond the bend, linear-golf-stick in the type, in 4-6 rows. Column incurved, about $12 \mathrm{~mm}$. long; winged narrowly in lower part, widely above ; 2 yellow sessile calli at the base. Anther pointed.

N.P. Widely distributed over the State (including Kangaroo Island) but not numerous ; reported from all the other States. Sept.-Oct.

8. C. dilatata (widened, referring to the lateral expansion of the labellum), R. Br. (Pl. 8, ii.) Often moderately robust, $15-45 \mathrm{~cm}$. high, hairy. Leaf very hairy, oblong to elliptical, lanceolate, often rather wide, $5-12 \mathrm{~cm}$. long. Flower solitary, large, often $10 \mathrm{~cm}$. in diameter, prevailing tints green, yellow, and maroon. Perianth-segments all spreading except dorsal sepal, yellowish-green with red central stripe; sepals clavate, subequal; petals narrower and shorter, not clavate. Dorsal sepal erect, lower-third dilated, thereafter contracted into a clubbed filiform point, about $5 \cdot 2 \mathrm{~cm}$. long; lateral sepals similar, the basal part deflexed, the points thereafter spreading and sometimes crossed. Petals falco-lanceolate gradually tapering into fine points, about $3 \mathrm{~cm}$. long. Labellum (figs. $5,6)$ maroon green and yellowish-white, tremulous on a movable claw, 3-lobed, somewhat ovate, about $2 \frac{1}{2} \mathrm{~cm}$. (including the claw); recurved near the middle; the lateral lobes: green, erect, their side margins entire, their anterior margins deeply combed or fringed; middle lobe recurved, widely lanceolate, margins toothed or serrate with maroon acute tip ; calli maroon, golf-stick type, in 4 rows hardly extending beyond the bend, those near the claw large, thick, and fleshy, the others small and linear. Column (figs. 7, 8) much incurved, about $15 \mathrm{~mm}$. long, widely winged, especially in the upper part; 2 yellow sessile calli at the base. Anther with well developed sharp point.

N.P. Widely and plentifully distributed throughout the State, reaching at least as far north as Burra; also New South Wales; Victoria; Tasmania ; and Western Australia. Sept.-Nov. 
9. C. filamentosa (thread-like, referring to the perianth-segments), R. Br. Very slender, slightly hairy, $15-30 \mathrm{~cm}$. high. Leaf narrow-linear, 7-15 cm. long, only slightly hairy. Flowers usually 1-3, uniformly crimson. Perianth-segments dilated in their basal fourth, thereafter produced into long hairy filaments. Dorsal sepal erect, incurved, about $5.2 \mathrm{~cm}$. long; lateral sepals spreading, about $5.7 \mathrm{~cm}$. long; petals spreading rather shorter than the dorsal sepal. Labellum ovate or cordate, about $6 \mathrm{~mm}$. long and $3 \mathrm{~mm}$. wide, on a short claw; erect against the column in its basal half, with shortly serrate margins ; thereafter recurved, the tip entire, not very acute; lamina with calli in 2 closely set rows extending to about the bend, sometimes marked with deeply crimson divergent veins on a lighter ground. Column about $7 \mathrm{~mm}$. high, with wide hatchet-shaped wings above, less widely winged below. Anther without a point.

Monarto South and Kangaroo Island; also New South Wales ; Victoria ; Tasmania ; and Western Australia.- Sept.

Var. tentaculata. Morphologically identical with the type but differing in coloration. Flowers cream-colored with dark markings. Perianth-segments cream-colored with reddish-brown central stripe and reddish-brown tips. Labellum with conspicuous reddish-brown divergent veins.-C. tentaculata, Tate, non Schlecht.

So far as is known the type has only one station on the mainland; the variety has not been reported from Kangaroo Island, where the type is plentiful.

Pichi Richi Pass; Caroona Hill (near Iron Knob); Yorke and Eyre Peninsulas ; Hundred of Goyder ; Wirrabara ; Monarto South ; also Victoria and Western Australia. Aug.Sept.

10. C. bicalliata (calli in 2 rows), Rogers. Small, slender, hairy, about $10 \mathrm{~cm}$. high. Leaf very hairy, linear-lanceolate, about $6 \mathrm{~cm}$. long, 3-nerved. Flower solitary, creamcolored, with red veinings, pedicel rather shorter than the ovary. Perianth-segments similar, dilated in their basal parts, then suddenly contracted into rather coarse cylindrical hairy caudae. Dorsal sepal about $2 \mathrm{~cm}$. long, one-third of which is dilated, incurved over the column ; the lateral sepals about $1.8 \mathrm{~cm}$., one-half of which is dilated, spreading ; petals subpatent, gradually contracted into caudae. Labellum cream-colored, about $7 \mathrm{~mm}$. long and $5 \mathrm{~mm}$. wide, ovate, on a short movable claw; erect in lower part, then recurved to a rather blunt apex; margins very shortly and bluntly serrate except the posterior one, which is entire ; lamina marked by conspicuous red divergent veins ; calli of the golf-stick type, in 2 well-defined rows, extending to within $3 \mathrm{~mm}$. of the extreme tip. Column about $8 \mathrm{~mm}$. long, erect, then incurved, widely winged in its upper third, narrowly below. Anther without a point.

Near Kingscote, Kangaroo Island. Sept.

11. C. Menziesii (after Archd. Menzies, a surgeon-botanist), R. Br. (Pl. 8, i.) Generally rather slender, $6-20 \mathrm{~cm}$. high, but sometimes much exceeding this. Leaf glabrous or almost so, of variable shape and size, usually ovate-lanceolate or broadly oblong-lanceolate, $3-6 \mathrm{~cm}$. long. Flowers 1-3, white and pink, occasionally entirely white. Dorsal sepal reddish, very glandular-hairy on the back, spathulate-lanceolate, contracted gradually towards the base, rather blunt, abruptly incurved over the anther, concave, about $11 \mathrm{~mm}$. long. Lateral sepals spreading, white, traversed by a pink stripe on lower surface, crescentic, wide in middle, contracted towards both ends, same length as the dorsal one. Petals (i., p.) reddish, very narrow-linear in lower half, clavate and closely glandular above, erect, about $20 \mathrm{~mm}$. long. Labellum (i., $l$; figs. 1, 2) on a short claw, about $7 \mathrm{~mm}$. long, including claw, white with conspicuous transverse pink markings, orbicularovate, undivided, erect at base, tip white, blunt, recurved; margins entire or nearly so ; calli on very slender pedicels with large rounded heads, arranged in 2.4 rows, not extending to the tip. Column (figs. 3, 4.) about $7 \mathrm{~mm}$. long, erect or slightly incurved, with transverse pink striae; widely winged throughout. Anther compressed laterally like a fireman's helmet, shortly pointed. Pollinia 4, lamellate but departing in shape from that prevailing in previous members of the genus, angular like a try-square.

N.P. and other parts of Mount Lofty Range; Hermitage; Golden Grove; Dingabledinga; Kuitpo; Kangaroo Island; also West Australia; Victoria; Tasmania. Sept.-Oct.

12. C. latifolia (wide-leaved), R. Br. Moderately robust, hairy, $15-30 \mathrm{~cm}$. high. Leaf very hairy, oblong-lanceolate, $4-10 \mathrm{~cm}$. long. Flowers moderately large, pink or white, 1-3. Perianth-segments lighter-colored on the outside, glandular-hairy, spreading with exception of dorsal sepal. Dorsal sepal oblong-lanceolate, erect, not very acute, about $15 \mathrm{~mm}$. long; lateral sepals free or slightly adherent at extreme base, equal to. or slightly longer and wider than the dorsal one, oblong-lanceolate. Petals elliptic-lanceolate; more contracted at the base, shorter and more acute than the other segments; $12-13 \mathrm{~mm}$. long. Labellum pink or white, sessile ; 6-7 mm. long; deeply 3-partite ; lateral lobes and base erect clasping the column, the former oblong obtuse, margins entire ; middle lobe recurved, broadly lanceolate, its margins with a few blunt linear teeth; calli of lamina linear or clavate, arranged semicircularly at or near the bend, or in 2 converging 


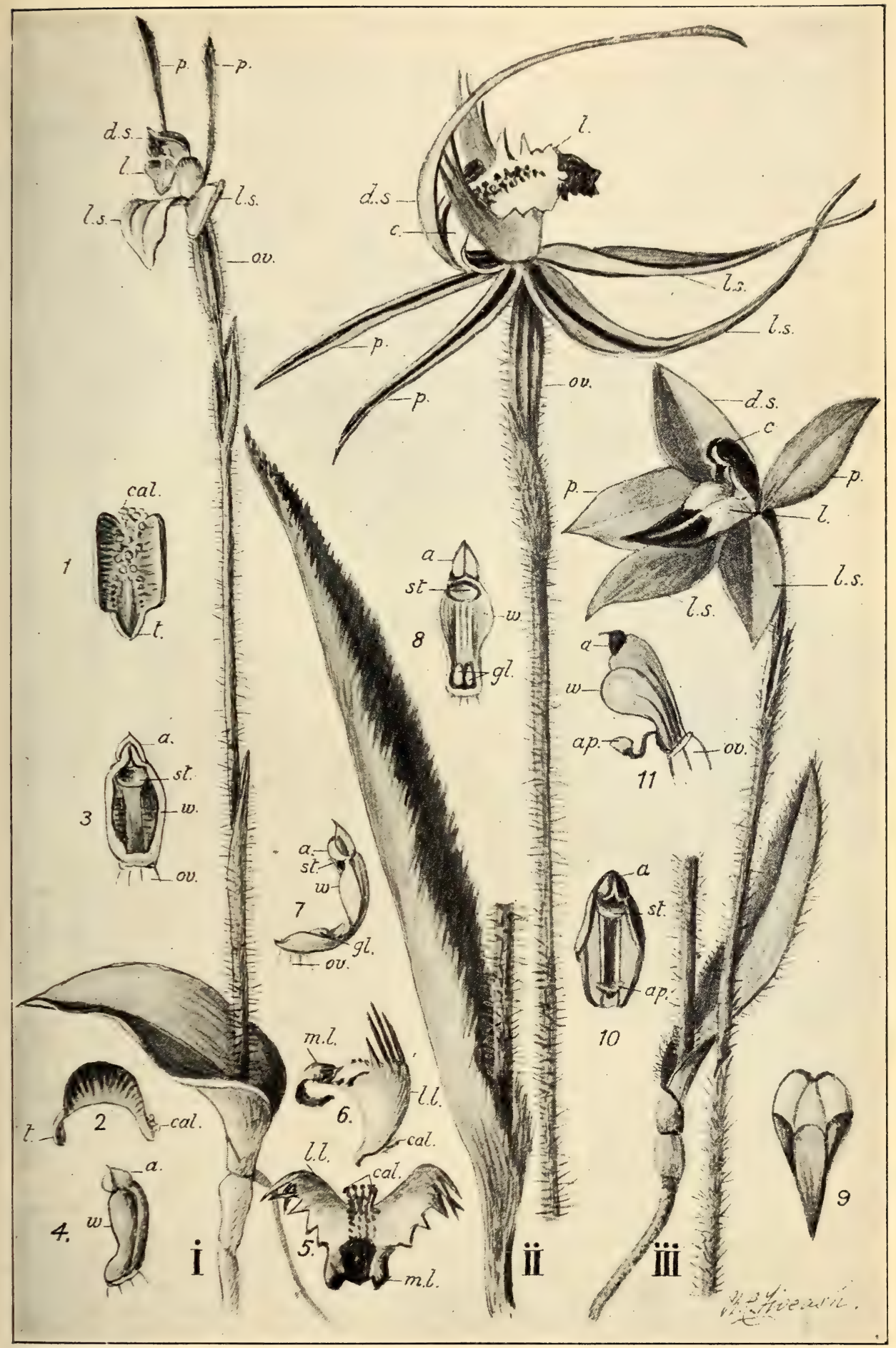

Plate 8.

i. Caladenia Menziesii. Plant nat. size. Fig. 1.-Labellum from above; $t$., tip. Fig. 2.-Labellum from

ii. the side: $t$., tip. Fig. 3.-Column from front. Fig. 4.-Column from side. All details enlarged.

adenia dilatata. Nat. size. Fig. 5.-Labellum from the front; l.l. lateral lobes; m.l. middle lobe.

Fig. 6.- Same from the side. Fig. 7.-Column from the side; g.l., sessile yellow calli at the base.

iii. Glossodia major. Nat, size. Fig. 9.-Labellum from above. Fig. 10.-Column from front. Fig. 11, - Same from side. Details slightly enlarged. 
rows. Column erect, 6-7 $\mathrm{mm}$. long, pubescent on the back, moderately winged throughout. Anther with a very long point. Pollinia 4, lamellate, a pair of deeply bilobed "butterfly" masses in each cell.

N.P. and other parts of Mount Lofty Range ; Beetaloo ; Angaston; Port Lincoln ; Yorke and Eyre Peninsulas; Inman Valley; Yeelanna; Goolwa; Millicent; Kangaroo Island; also all other States. Sept.-Oct.

13. C. carnea (flesh-colored), R. Br. Very slender, $8-20 \mathrm{~cm}$. high. Leaf hairy, narrowlinear often as long as the scape. Flowers 1-3, pink, more rarely white. Perianthsegments a dusky-green, with glandular-hairs and pink stripes on the outside, pink and glabrous within; tips generally acute, but sometimes blunt. Dorsal sepal erect or slightly incurved, linear, 11-14 mm. long; lateral sepals free, spreading, generally longer than the dorsal sepal, 11-17 mm., lanceolate or falco-lanceolate. Petals narrower than the sepals, but about the same length, spreading, falco-lanceolate; sometimes, especially in the smaller forms of the species, all the segments of the perianth equal. Labellum sessile, 3-partite, erect at base, recurved beyond the middle ; lateral lobes broad, erect, prominent with rounded anterior border and entire margins; middle lobe lanceolate, more or less dentate or fringed with a few calli ; lamina with two rows of stalked clubbed calli (sometimes larger and in 4 rows at the base), not extending beyond the bend, with interrupted transverse red linear bands, about $6 \mathrm{~mm}$. long. Column about $6 \mathrm{~mm}$. long, incurved, rather narrowly winged, with transverse linear red markings anteriorly. Anther with rather a long point.

N.P. Widely distributed; reported as far north as Beetaloo and Wirrabara Forest ; south from Millicent and Mount Gambier; west from Yorke and Eyre Peninsulas and Kangaroo Island; also from all other States. Sept.-Oct.

14. C. congesta (crowded, referring to the calli), R. Br. Slender, slightly hairy, $15-60 \mathrm{~cm}$. high. Leaf linear, $7-12 \mathrm{~cm}$. long, very slightly hairy. Flowers pink, 1-3, on slender pedicels. Perianth-segments covered with glandular hairs on the outside, all spreading except dorsal sepal. Dorsal sepal shorter than the other segments, about $12 \mathrm{~mm}$., incurved over column, lanceolate ; lateral sepals about $18 \mathrm{~mm}$. long, elliptical-lanceolate Petals about $14 \mathrm{~mm}$. long, falcate. Labellum pink, about $9 \mathrm{~mm}$. (extended), on a rather long and narrow claw; basal-half erect against the column, thereafter gradually curved forward; very distinctly 3-lobed; lateral lobes falcate, acute, reaching well beyond the middle of labellum, margins entire; middle lobe oblong-lanceolate, much elongated and very narrow, margins entire. Calli dark-crimson, imbricate, completely covering middle of labellum to the very tip ; at first placed longitudinally in 2 rather obscure rows, the 2 nearest the claw being stalked, the others large sessile, flat-topped, more or less oblong. Column about $8 \mathrm{~mm}$. long, incurved, with rather wide wings, especially in the upper part, blotched with pink markings. Anther pointed.

Glencoe, near Mount Gambier; also New South Wales; Victoria; Tasmania. Nov.

15. C. testacea (brick-red), R. Br. Slender, sparsely hairy, $15-45 \mathrm{~cm}$. high. Leaf narrow-linear, very slightly hairy, 6-12 cm. long. Flowers dark and glandular on the outside, white inside, $1-5$ in a raceme, on slender pedicels ; buds characteristic, bluntly falcate in shape, covered with dark glandular hairs. Perianth-segments generally dark reddish-brown (except towards the base) on outside, white or light-colored within ; subequal; all spreading except the dorsal sepal. Dorsal sepal erect incurved, about $10 \mathrm{~cm}$. long, concave, acute, contracted at the base; lateral sepals slightly longer than other segments, elliptic-lanceolate. Petals falco-lanceolate. Labellum about $7 \mathrm{~mm}$. long (extended and including claw), on a movable claw, the basal portion erect against the column, recurved forward about the middle; margins entire except towards the triangular tip, the edges of which are shortly and sparsely denticulate; labellum obscurely 3 -lobed, the lateral lobes being ill-defined; calli of the lamina in 4 rows reaching almost to the extreme tip, where the rows are not so evident, clubbed, the stalks shorter towards the tip. Column $7.8 \mathrm{~mm}$. long, incurved, widely winged, especially in upper part.

Glencoe and Millicent Flats; also New South Wales; Victoria; Tasmania. Nov.

16. C. coerulea (sky-blue), R. Br. Slender, sparsely hairy, with the habit of $C$. carnea, $8.15 \mathrm{~cm}$. high. Leaf linear-lanceolate, only slightly hairy. Flower solitary, bright blue, very rarely white. Perianth-segments lighter-colored externally and beset with minute dark-blue glandular hairs, all contracted at base. Dorsal sepal about $11 \mathrm{~mm}$. long, narrower than lateral sepals, erect, concave, 3-nerved, slightly incurved, rather blunt; lateral sepals about $13 \mathrm{~mm}$. long, elliptic-lanceolate, acute, spreading, 5-nerved. Petals about as long as lateral sepals, but rather narrower, spreading, 5-nerved. Labellum (when extended) about same length as column; on a short claw; distinctly 3-lobed; lateral lobes erect and embracing the column, broad and rounded with entire margins; middle lobe much recurved, narrow, cuneate, hardly acute, with entire margins ; lamina with transverse linear dark-blue bands on a lighter ground; calli linear, yellow, clubbed, in 2 rows extending to the extreme tip. Column about $7 . \frac{1}{2} \mathrm{~mm}$. long, much incurved, moderately winged throughout. Anther with a distinct point.

Bugle Ranges; also all eastern States and Tasmania. Aug.-Sept. 
17. C. deformis (mis-shapen), R. Br. Slightly hairy, 6-15 $\mathrm{cm}$. high. Leaf almost glabrous, linear-lanceolate, 5-6 $\mathrm{cm}$. long and $4 \mathrm{~mm}$. wide. Flower solitary, deep blue, occasionally white. Perianth-segments light-colored on the outside with many scattered minute purple glands, spreading with exception of the dorsal sepal, which is generally erect or recurved. Dorsal sepal about $19 \mathrm{~mm}$. long, not very acute, elliptic-lanceolate, 5-nerved; lateral sepals not so long, about $17 \mathrm{~mm}$., falco-lanceolate. Petals sometimes erecto-patent, obliquely oblong-lanceolate, about as long as the lateral sepals. Labellum contracted towards the base, sessile, about $11 \mathrm{~mm}$. long (when extended) and $7 \mathrm{~mm}$. wide; obcuneate, its lower two-thirds erect, clasping the sides of the column; obscurely 3-lobed; the lateral lobes toothed anteriorly, their margins otherwise entire, not very prominent; middle lobe triangular recurved, dark purple, fringed with dentate calli ; calli of lamina linear or slightly clubbed, in 4-6 rather ill-defined rows, not quite extending to the extreme tip, somewhat crowded, those at the base tomentose. Column about $10 \mathrm{~mm}$. long, incurved, winged throughout, broadly so in its upper-half; the wings united shortly in front of the base; more or less purple with deep purple dots and markings. Anther with a long acute point. Pollinia 4, free, lamellate, elongate crescentic.

N.P. Very widely distributed, certainly extending as far north as Pichi Richi Pass near Quorn and possibly into Central Australia; as far west as Yeelanna in Eyre Peninsula and south to Robe ; Millicent; Mount Gambier; Kangaroo Island. It also occurs in all the other States except Queensland. July-Aug.

18. C. tutelata (guardian, protecting; referring to the tall sentinal calli at the base of labellum), Rogers. Slender, almost glabrous, $15-22 \mathrm{~cm}$. high. Leaf oblong or oblonglanceolate, very slightly hairy, about $8 \mathrm{~cm}$. long and $6 \mathrm{~mm}$. wide. Flower solitary, dark blue, about the size and color of a well-developed Glossodia major. Perianth-segments lighter-colored on the outside, dotted with minute dark purple glands, subequal, all spreading with exception of the dorsal sepal, not very acute. Dorsal sepal about $2 \cdot 1 \mathrm{~cm}$. long, elliptic-lanceolate, erect or slightly incurved, blunter than the other segments; lateral sepals rather wider, elliptic-lanceolate; petals about the same width as the lateral sepals but slightly shorter, falco-lanceolate. Labellum undivided, on a very short claw, almost sessile, ovate, about $11 \mathrm{~mm}$. long and $5 \frac{1}{2} \mathrm{~mm}$. wide, the apex acute, margins entire except for very minute denticulations near the tip; basal half erect clasping the column; thereafter gradually recurved. Calli of the lamina of the golf-stick type, the filaments purple or white, heads white or yellow, generally in 2 well-defined rows as far as the middle; thereafter of less regular distribution and shape, sometimes sessile ; occasionally reduced to a few tall basal calli ; 4 tall sentinel calli of the golf-stick type, about $3 \mathrm{~mm}$. long, attached to the extreme base of the lamina standing vertically in front of the column, sometimes quite free, sometimes with a tendency to cohere or fuse so as to form 2 broad-filamented double-headed calli. Column about $10 \mathrm{~mm}$. long, erect, not much incurved, broally winged in its upper half, narrowly winged below; dorsal surface pubescent. Anther with a long point (nearly $2 \mathrm{~mm}$.).

Blackwood. Sept.

\section{GLOSSODIA, R. Br.}

(Greek glössōdes, tongue-shaped.)

Perianth-segments nearly equal, spreading. Labellum (Pl. 8, iii., fig. 9) sessile, undivided, margin entire, its lamina without glands calli or plates, but at its base 2 (sometimes fused) linear clubbed calli or appendages (figs. 10, 11, ap.) erect against the column, and from half to nearly its whole length. Column erect, incurved, 2 -winged. Anther erect, 2 -celled, the outer valves broad, the inner much smaller, the connective produced into a small point. Pollinia 4, lamellar, unconnected with the rostellum, granular.-Terrestrial herbs, more or less hairy, growing from small underground tubərs. Leaf solitary, radical, oblong or lanceolate, from within a scarious sheath close to the ground. Flowers 1 or 2, blue or purple on an erect scape with a sheathing bract at or near the middle and a similar bract under each pedicel.

A small genus of 5 known species, endemic to Australia.

1. G. major (the larger Glossodia), R. Br (PI. 8, iii.). Slender, hairy, $10-25 \mathrm{~cm}$. high. Leaf solitary, hairy, oblong or oblong-lanceolate, 3-7 cm. long. Flowers 1 or 2, usually purple, rarely white. Perianth-segments all spreading; subequal, $20-25 \mathrm{~mm}$. long, and $6.10 \mathrm{~mm}$. wide, their bases white with purple dots, elliptic-lanceolate, not very acute, outer surface light-colored and glandular-hairy. Labellum (fig. 9) sessile with a contracted base, ovate-lanceolate, $10-11 \mathrm{~mm}$. long and $5 \mathrm{~mm}$. wide; the posterior part white and pubescent; at first erect, but soon recurved forward, dilated laterally into 2 convexities or bosses with a furrow between them; the anterior half purple, glabrous, margins entire; a large purple sigmoid linear appendage (figs. 10, 11 ap.), with a broad fleshy-yellow bilobed head at the extreme base, erect against the column. Column erect in its lower part, incurved above, $9-10 \mathrm{~mm}$. long; broadly winged, especially in its upper part. Anther with acute point.

N.P. ; rather widely distributed from Angaston to Mount Gambier ; not reported from western parts, nor from Kangaroo Island; also in all Eastern States, including Tasmania. Sept.-Oct. 


\section{DIURIS, Sm.}

(Greek dis, two ; oura, a tail : referring to the lateral sepals.)

Dorsal sepal erect or slightly recurved at the apex, more or less ovate, its tip blunt"and its base clasping the column ; lateral sepals narrow-linear, often herbaceous, spreading or deflexed, parallel or crossed, exceeding the dorsal sepal in length. Petals longer than the dorsal sepal, oval, elliptical or orbicular on slender stalks, erect or spreading. Labellum usually as long or longer than the dorsal sepal ; deeply 3 -lobed (text fig. $33, \mathrm{~A} ; l l b, m l$.) ; the middle lobe much contracted at the base, with 1 or 2 raised longitudinal lines along the narrow part. Column very short, the sexual elements arising separately from the floral receptacle (figs. 1-4) at first quite separate, but united as the flower approaches maturity, by an adhesion between the pollen-masses and the viscid disk of the rostellum. Anther erect, 2-celled, on a very short filament, margins of the filament produced into erect lateral lobes or wings not adnate to the stigmatic-plate. Stigma borne on a widened style or "plate" in front of the anther, a slot in its upper border representing the rostellum and likewise enclosing the locse viscid disk, the latter attached at maturity to the apices of the pollinia without intervention of a caudicle. Pollinia 2, each deeply bilobed, suspended behind the stigma from the back of the viscid disk. Pollen-masses mealy.Terrestrial glabrous plants with underground tubers and several imbricated scales at base of the scape. Leaves more than one, generally several, narrow, at or near the base, with a few stem-bracts higher up. Flowers 1, 2, or more, in a terminal raceme, rather large and conspicuous, yellow, purple or white, often spotted or blotched with dark-brown or purple.

The genus is endemic to Australia, and contains 26 valid species.

Flowers not blotched or spotted on their upper surface, but of a uniform color.

Flowers purple or heliotrope (drying yellowish-brown); lateral sepals greatly exceeding petals, about $5 \mathrm{~cm}$.

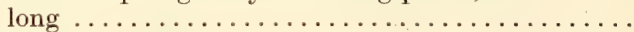

Flowers canary-yellow; lateral sepals only slightly exceeding petals ................................

Flowers yellow with conspicuous dark-brown or purplebrown markings or blotches.

Lateral lobes of labellum large, as long or nearly as long as middle one.

Lateral sepals greatly exceeding petals in length, often nearly twice as long; leaves 6 or more, setaceous

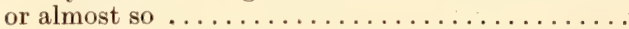

Lateral sepals shorter than, or approximating in length to the petals; leaves not setaceous.

Lateral sepals crossed; blotches generally distinctly demarcated from the yellow ground-color; 2 longitudinal raised lines at base of labellum ...

Lateral sepals nearly parallel; flowers wall-flower color, dark blotches merging into yellow groundcolor ; 1 raised line at base of labellum........

Lateral lobes of labellum very much shorter than the middle one.

Two raised longitudinal lines along base of labellum.

Flowers with small dots and short linear markings; leaves linear and rather lax, often $17 \mathrm{~cm}$. long. .

Flowers with 2 conspicuous brown dots at base of dorsal sepal and conspicuous oblong brown border round the raised lines; leaves usually more than 5, setaceous or nearly so; short

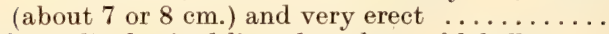

One longitudinal raised line along base of labellum.

Flowers with similar markings to $D$. brevifolia, and in addition a brown transverse blotch near the tip of middle lobe of labellum; leaves usually 2 , rarely 3 , long lax, linear . . . . . . . . .

\section{D. punctata 1 .}

D. pedunculata 2.

D. palustris 3 .

\section{D. maculata 4.}

\section{D. longifolia 5 .}

\section{D. palachila 6 .}

\section{D. brevifolia 7 .}

\section{D. sulphurea 8 .}

1. D. punctata (dotted, a misnomer), Sm. Slender, glabrous, $30-60 \mathrm{~cm}$. high. Leaves usually 2, linear, channelled, $15-20 \mathrm{~cm}$. long. Flowers 2-5, heliotrope, not dotted, on long slender pedicels enclosed more or less in loose subulate bracts. Dorsal sepal broadly ovate, erect, or recurved at apex, about $16 \mathrm{~mm}$. long; lateral sepals about $5 \mathrm{~cm}$. long, green, very narrow-linear, spreading, usually parallel. Petals on a narrow claw, about $6 \mathrm{~mm}$. long ; lamina elliptical or elliptical-oblong; total length about $22 \mathrm{~mm}$. Labellum purple, about $14 \mathrm{~mm}$. long; 3-lobed; middle lobe broadly ovate or semicircular on a narrow base; lateral lobes less than half as long, oblong-falcate, erect with outwardly curved tips, margins entire or crenulate ; lamina traversed at the base by 2 conspicuous 
and rather closely approximated raised longitudinal lines ending near the middle in 2 tooth-like processes. Lateral appendages of column more or less lanceolate, as high as the anther, their front margins yellow, sinuous, nearly meeting each other in front of the stigmatic plate.-D. elongata, Sw.

Mount Gambier district; also Queensland; New South Wales ; Victoria. Oct.-Noy.

2. D. pedunculata (stalked), R. Br. Slender, glabrous, usually $20-40 \mathrm{~cm}$. high. Leaves generally 5-7, linear, $10-15 \mathrm{~cm}$. long. Flowers large, solitary, or $2-4$ on very slender pedicels, racemose, canary-yellow, with brown or greenish-brown tinges on the outer surface of the perianth-segments and labellum at the base. Dorsal sepal yellow, broadly ovate, erect, much shorter than the other segments of the perianth, also shorter than the labellum, about $14 \mathrm{~mm}$. long ; lateral sepals free, green, linear-lanceolate, channelled on the inner side, spreading below the labellum, $20-23 \mathrm{~mm}$. long. Petals with yellow elliptical lamina; the stalks green, linear, about $6 \mathrm{~mm}$. long; with a total length of $16-17 \mathrm{~mm}$. ; spreading in the mature flower. Labellum yellow, about $18 \mathrm{~mm}$. long and $12 \mathrm{~mm}$. wide, almost flat in mature flower, tip very blunt, spreading; lateral lobes narrow falco-lanceolate, toothed on their outer margins, 6-7 mm. long, recurved outwards; middle lobe on a contracted base, ovate-rhomboid, about 3 times as long as the lateral ones; the lamina with 2 raised rather widely separated pubescent longitudinal lines on the base, the lines often laminate, ending dentately a little beyond the contracted part, then continued as a single line or fold towards the tip. Anther flat or almost so, shorter than the viscid disk. Lateral appendages narrowly ovate-lanceolate, very acuminate, margins slightly toothed, same height as anther.

N.P. and Mount Lofty Range ; Clare ; Beetaloo ; Angaston ; Kooringa ; Hundred of Goyder; Millicent district; also all Eastern States and Tasmania. Sept.

3. D. palustris (swampy), Lindl. Small, glabrous, about $10 \mathrm{~cm}$. high, seldom exceeding $18 \mathrm{~cm}$. Leaves 8-10, erect, usually more than half the length of scape, channelled, setaceous and twisted or very narrow-linear. Flowers rather small, 1-4 on long slender pedicels, yellow blotched with dark-brown, the dark color prevailing on the outside ; pervaded by faint odour of spice or nutmeg. Dorsal sepal ovate, recurved in the upper half, purple or dark-brown behind the anther, yellowish beyond this, about $8 \frac{1}{2} \mathrm{~mm}$. long ; lateral sepals green, free, linear, parallel, spreading below the labellum, about $16 \mathrm{~mm}$. long; petals stalked more than about half as long as lateral sepals ; the pedicel purplish, narrow-linear, about $4 \mathrm{~mm}$. long; the lamina yellow, oval, emarginate at the tip, recurved, about $6 \mathrm{~mm}$. long and $4 \frac{1}{2} \mathrm{~mm}$. wide. Labellum about $6 \frac{1}{2} \mathrm{~mm}$. long; lateral lobes erect, about $4 \frac{1}{2} \mathrm{~mm}$. long, oblong with rounded crenate anterior margins, margins otherwise entire, yellow on inner surface, much blotched outside; middle lobe oblong; lamina with 2 thick fleshy parallel longitudinal raised lines from the base to beyond the middle, thereafter merging into a single short raised line dilating at the anterior margin into a rounded emarginate eminence; dark-brown spots at end of the 2 raised lines and also at the tip. Anther blunt, rather narrow, a little higher than the rostellum.

N.P. and Mount Lofty Range; Hornsdale; Wirrabara Forest; Crystal Brook ; Beetaloo; Pichi Richi Pass; Angaston; Goolwa; Monarto; Robe ; Millicent ; Yorke Peninsula; also Victoria and Tasmania. Aug.-Sept.

4. D. maculata (spotted), Sm. Moderately slender, seldom exceeding $30 \mathrm{~cm}$. high. Leaves 2 or 3, narrow-lanceolate, channelled, rarely exceeding $10 \mathrm{~cm}$. long. Flowers from 2-6, on rather slender pedicels in a flexuose raceme; yellow, much blotched with dark-brown, the latter color rather distinctly demarcated from the ground yellow and not merging into it (as in D. longifolia), the undersurface of the perianth more blotched than the upper. Dorsal sepal more or less ovate; margins irregularly sinuous, apex bent forward; about $9 \mathrm{~mm}$. long; lateral sepals rather stoutly linear with oblique points, greenish, recurved and crossed in the mature flower, about $11 \frac{1}{2} \mathrm{~mm}$. long. . Petals with a total length of $15 \mathrm{~mm}$.; the stalk linear, dark-brown, reflexed, about $6 \mathrm{~mm}$.; lamina orbicular or almost so, spreading, upper surface yellow, lower surface much blotched with dark-brown. Labellum shorter than dorsal sepal, about $6 \mathrm{~mm}$. long; lateral lobes upturned with wide crescentic crenate recurved anterior margins, as long as middle lobe ; middle lobe obcuneate with widely retuse truncate tip; lamina with 2 rather widely separated fleshy prominent raised lines ending about the middle in 2 acute teeth. Anther with very short point, about as high as the viscid disk.

N.P. and Mount Lofty Range; Kooringa; Yeelanna; and many other parts of the State; also in all eastern States and Tasmania. Sept.

5. D. longifolia (long-leaved), R. Br. (Text fig. 33, figs 1-4.) Stouter than most other members of the genus, $10-45 \mathrm{~cm}$. high. Leaves 2 or 3 , linear or lanceolate, acute, channelled, usually of unequal length, $7-20 \mathrm{~cm}$. long, 4-12 mm. wide. Flowers large, sometimes solitary, more often $2-5$ on slender pedicels in a loose raceme, yellow and brown, the two colors suffusing into each other as in the wall-flower. Dorsal sepal much shorter than the other segments, very broad and rounded, about $10 \mathrm{~mm}$. long; lateral sepals green, linear, rather stout, spreading horizontally, with blunt oblique points, usually parallel but occasionally crossed, $18.19 \mathrm{~mm}$. long. Petals stalked, recurved or spreading; 
the claw about $4 \mathrm{~mm}$. long; the lamina oval or elliptical, about $16 \mathrm{~mm}$. long. Labellum about $10 \mathrm{~mm}$. long, dark-brown and yellow blended; lateral lobes nearly as long as the middle one, wide, obcuneate, margins entire, the anterior one rounded, recurved, about $10 \mathrm{~mm}$. long (from base of labellum); middle lobe about the same length or a little longer, its anterior border rounded and retuse; lamina with a single (very rarely double) raised line at its extreme base merging into a central keel extending to the tip. Anther without a point, about the same height as the viscid disk of the rostellum. Lateral appendages about the same height, linear-falcate, with an irregular upper border.

N.P. Distributed very widely in this and all other States except Queensland. Sept.-Oct.

6. D. palachila (spade-shaped labellum), Rogers. Slender, glabrous, $10-40 \mathrm{~cm}$. high. Leaves 2.5, narrow-linear or linear, somewhat lax, often reaching a length of $17 \mathrm{~cm}$. Flowers 1-3 on long and slender pedicels, yellow with brown markings. Dorsal sepal yellow, usually with brown blotchings or dots ehiefly on the outer surface near the base and around the margins, about 11 mm. long; lateral sepals green, linear, acuminate, spreading below the labellum parallel or more rarely crossed, about 15 $\mathrm{mm}$. long. Petals of similar color and markings to the dorsal sepal; stalk greenish-brown about $4 \frac{1}{2} \mathrm{~mm}$. long; lamina elliptical about $10 \frac{1}{2} \mathrm{~mm}$. long; spreading. Labellum yellow with dark brown dots, short linear splashes and blotches especially on its lower surface; about $11 \mathrm{~mm}$. long; lateral lobes about $6 \frac{1}{2} \mathrm{~mm}$. long (rather more than half the length of the middle one), narrow-lanceolate with upturned dentate margins and outwardly curved free ends; middle lobe spade or shovel shaped, apex erescentic; lamina with 2 widely separated raised longitudinal lines on the narrow base, ending abruptly in 2 teeth at the expanded part, thereafter merged into a central keel extending to the apex. Anther as high as viscid disk of rostellum, rather flat with a very short point. Lateral appendages of the column as high as the anther, oblong-falcate, anterior margins dentate.

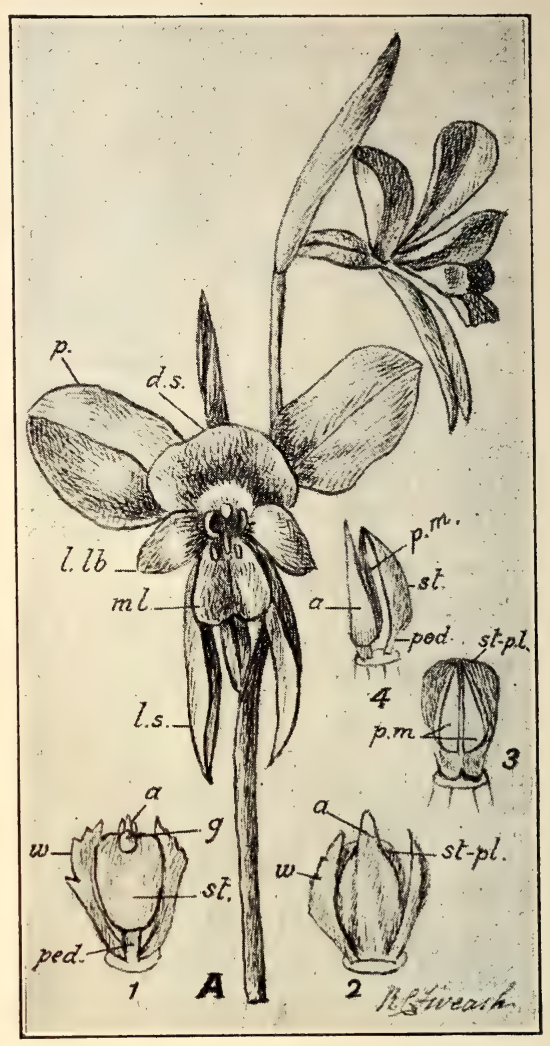

Text-figure 33.-A. Two flowers of Diuris longifolia, front and side views; $l l b$, lateral lobe labellum ; $m l$, middle lobe of labellum. All natural size. Fig. 1.-Column from front; $p$ ed., pedicel (style) of stigma, which together with the stigma (st.) and viscid disk $(g)$ constitutes the stigmatic-plate. Fig. 2.-Same from back; st-pl, stigmatic plate. Fig. 3. Same with anther and wings removed, showing the pollinia $(p m$.) hanging from the back of the viscid disk. Fig. 4.- Same from the side, wings removed; the pollinia can be seen between the anther $(a)$ and stigmatic-plate. All details enlarged.

N.P. and Mount Lofty Range ; Angaston; McLaren Vale ; Golden Grove ; Robe ; also from Victoria. Sept.

7. D. brevifolia (short-leaved), Rogers. Slender, glabrous, $15-40 \mathrm{~cm}$. high. Leaves generally 4-8, linear or setaceous, acuminate, not twisted, very erect, usually $7-12 \mathrm{~cm}$. long, rarely reaching beyond the middle of the stem. Flowers solitary or in a loose raceme of $2-4$, on slender pedicels, yellow with a few brown markings, much smaller than those of $D$. sulphurea. Dorsal sepal ovate, yellow with a dark brown spot on each side of the dorsum near the base, recurved, about $11 \mathrm{~mm}$. long; lateral sepals green, about $15 \mathrm{~mm}$. long, linear, acuminate, parallel, spreading below the labellum or slightly recurved. Petals shortly stalked, about $14 \mathrm{~mm}$. long, spreading, recurved; lamina canary-yellow, elliptical, about $11 \mathrm{~mm}$. long. Labellum yellow, at least as long as the dorsal sepal and generally longer, about $12 \mathrm{~mm}$. long; lateral lobes less than half as long as central lobe, generally about $5 \mathrm{~mm}$., not very wide, margins entire, tips recurved ; middle lobe rhombocuneate with depressed antero-lateral margins; lamina with 2 closely approximated parallel raised lines on the basal half continuous with the anterior central keel, the lines surrounded in front and on both sides by a conspicuous dark brown border. Anther 
without a definite point, rather higher than the viscid disk of the rostellum. Lateral appendages of the column subulate or linear-falcate, about same height as the viscid disk.

Longwood and Mount Lofty Range; Myponga; Mount Compass; Port Elliot; Kangaroo Island. Nov.-Dec.

8. D. sulphurea (sulphur-colored), R. Br. A stouter and larger plant than the preceding, often $50 \mathrm{~cm}$. high. Leaves 2 or rarely 3 , much exceeding the middle of the stem, 18-45cm. long, lax, linear, never setaceous. Flowers large, often upwards of $5 \mathrm{~cm}$. in the long diameter, yellow with dark brown markings closely resembling those of $D$. brevifolia but with an additional transverse marking across the tip of the labellum ; $3-6$, on long slender pedicels. Dorsal sepal ovate, recurved, about $20 \mathrm{~mm}$. long ; lateral sepals linear, acuminate, about $22 \mathrm{~mm}$. long, spreading, usually parallel, but sometimes crossed. Petals spreading 20-21 mm. long; stalk 5-6 mm. long; lamina elliptical about $15 \mathrm{~mm}$. long. Labellum sessile, much shorter than dorsal sepal, about $12 \mathrm{~mm}$. long; lateral lobes rather wide and blunt, obovate, hardly half as long as the middle lobe; middle lobe rhombo-cuneate, wide but depressed on each side of the central line; lamina with a single conspicuous raised longitudinal line from the base to a little beyond the middle, where it merges into the natural central keel or fold of the lobe. Anther hardly pointed, its apex as high as the viscid disk of the rostellum. Lateral appendages of column slightly exceeding this, semiovate, incurved.

Mount Gambier district; also in all the eastern States and Tasmania. Nov.

\section{ORTHOCERAS, R. Br.}

(Greek orthos, straight ; keras, horn.)

Dorsal sepal rather broad, incurved, contracted at the base, hood-shaped; lateral sepals much longer, narrow-linear, spreading laterally. Petals short, erect, often oblong or cuneate. Labellum recurved, 3-lobed; the middle lobe contracted at the base and much longer than the lateral ones; a large fleshy callus at the base. Anther erect or incurved, tapering to the apex, 2-celled, on an extremely short filament arising from the posterior border of the floral receptacle; the lateral appendages or wings of the filament erect or incurved and adnate to the base (the style) of the stigmatic-plate as in some members of the genus Prasophyllum. The stigmatic-plate, carrying the stigma and rostellum, erect in front of the anther. Pollen-masses 2, each bilobed, cohering near their apices; suspended loosely from the anther-septum after dehiscence, but later dropping on to the back of the stigmatic-plate without any sort of attachment to the rostellum; mealy and friable. The viscid disk of the rostellum and caudicle absent.Terrestrial glabrous herbs, with more or less ovoid tubers; 2 or 3 membranous scales at the base of the scape. Leaves radical or almost so, several, linear. Flowers on short pedicels, rather distant and racemose.

The genus contains but one species which is found also in New Zealand.

1. O. strictum (upright), R. Br. (Text fig. 34, B.) A rigid species with the characters of the genus, $15-45 \mathrm{~cm}$. high, Leaves $2-5$, acute, channelled, sheathing at the base. Stem-bracts 1, sometimes 2, at or about the middle, with long sheathing base and subulate lamina. Flowers greenish-brown or quite green, 2-7 on rather short pedicels. Dorsal sepal with an acute apex, about $11 \mathrm{~mm}$. long; lateral sepals almost terete, at maturity laterally spreading on each side of the hood, about $2.7 \mathrm{~cm}$. long. Petals hidden by the dorsal sepal. about $5 \mathrm{~mm}$. long, tips rather blunt and usually notched. Labellum sessile, about $10 \mathrm{~mm}$. long and $7 \mathrm{~mm}$. wide; the lateral lobes broad, erect, not more than half the total length, margins entire; middle lobe somewhat elliptical with entire margins ; lamina smooth except for a large pyramidal callus at the base. Column about $4 \mathrm{~mm}$. long. Anther without a point, much incurved. Lateral appendages of column variable in length but usually same height as rostellum.

N. P. and Mount Lofty Range ; Golden Grove ; Goolwa ; Millicent district ; also all Eastern States, Tasmania, and New Zealand. Nov.-Dec.

\section{SPIRANTHES, Richard.}

(Greek speira, a coil ; anthos, a flower.)

Perianth-segments subequal. Dorsal sepal erect or incurved over the column, ovate, concave; lateral sepals free, ovate-lanceolate, erect or spreading. Petals truncate, erect, their posterior margins concealed by the dorsal sepal and forming with that segment a hood. Labellum about as long as the sepals, on a very short claw, undivided; the lower half erect with entire margins embracing the column; the tip recurved; the lamina with 2 rounded glandular bodies at the base. Column erect, very short, contracted in the lower half, clinandrium expanded. Anther blunt or very minutely apiculate, incumbent against the back of the stigma, valvate, 2-celled. Column-wings membranous, stretching between the anther-filament and the stigmatic-plate, adnate to the pedicel (style) of the latter and also to the margins of the stigma itself, forming a pouch between the male and female elements. Stigmatic surface large, about the same length as the rostellum. Rostellum forming with the viscid disk a long membranous structure much exceeding the anther 
in height. The disk accommodated in a fork of the rostellum and covered by a membranous capsule. Pollinia is 2 pairs, granular, the apices of the pairs lightly united, exposed above the anther and attached by a short caudicle to the back of the disk.Terrestrial herbs with elongated underground tubers. Flowers small, sessile in a spiral spike. Leaves narrow or linear, several, basal, or nearly so.

A fairly large genus cosmopolitan in its distribution; represented in Australia by a single recorded species, which extends to New Zealand, and has also a wide range over Asia and a portion of Europe.

1. S. australis (southern), Lindl. (Text fig. $34 \mathrm{~A}$, ). A slender marsh-plant with the characters of the genus; arising from several (often 6) elongated conical or terete tubers; $15-45 \mathrm{~cm}$. high. Leaves 3, 4-10 cm. long. Stem-bracts usually 3. Flowers white or pink, the subtending bracts ovate, pubescent on the outside, about as long as the ovary ; ovary pukescent, shortly ovoid. Perianth-segments $4 \frac{1}{2}-5 \mathrm{~mm}$. long; the petals rather wider at the tips than at the base. Labellum white, more or less rectangular, the lower half bulging at the base; the tip truncate, the margins fringed or glandularly dentate : a large ovoid body on each side of the lamina at the base. Column about $3 \mathrm{~mm}$. long, fleshy. Anther reaching to about the base of the rostellum. Stigmatic surface U-shaped, slightly sloping downwards. The disk of the rostellum slate-colored, long, narrow-elliptical (boatshaped), covered by a membranous capsule derived from the rostellum. Pollinia lamellate. pear-shaped.

Myponga; Mount Compass; Millicent district: all other States except Western Australia. Jan. Feb.

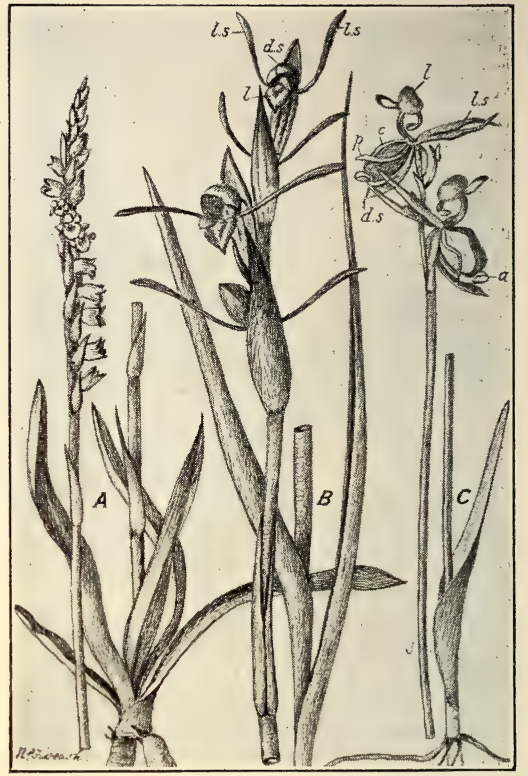

Text-figure 34-A. Spiranthes australis, showing the plant. B. Orthoceras strictum, showing the plant with exception of middle of stem. C. Caleana major, the plant. All reduced in size.

\section{CRYPTOSTYLIS, R. Br.}

(Greek kry?tos, hidden ; stylos, the column.)

Flowers large, reversed. Segments of the perianth free, similar in shape, linearlanceolate or subulate. Labellum much more conspicuously developed and colored than the petals and sepals, undivided, sessile, the base enclosing the column and more or less contracted above the latter, lamina broad or rather narrow-convex or concave. Column wide and exceedingly short, the wings forming distinct auricles or produced posteriorly into a glandular or membranous process with toothed or fimbrate margins behind the anther (Pl. 9, i., figs. 4. 5, $u$.). Anther erect behind the stigma or incumbent over it, sessile, 2-celled, biconvex on the back, blunt or shortly acuminate at the apex. Pollinia 4, an upper and a lower mass in each cell, lamellate, ovate, granular; the apices of each pair connected directly with the viscid disk of the rostellum, without the intervention of a caudicle. Stigma large and fleshy, its upper border produced into a somewhat triangular rostellum bearing a conspicuous viscid disk.-Terrestrial glabrous herbs with tuberous rhizome. Leaves few, radical, on rigid petioles, ovate to lanceolate. Stems usually with 2 or 3 appressed bracts. Flowers with a large reddish-krown, pink or purple label. lum ; several in a terminal raceme.

A small genus of 18 known species, the 4 Australian ones being endemic; others are reported from the Malay Archipelago; New Guinca; Formosa; Philippines;... New Caledonia; Fiji : and Samoa.

1. C. longifolia (long-leaved), R. Br. (Pl. 9, i. ; figs. 1-5.) Slender, 30-90 cm. high. Leaves 2 or 3 , on petioles $1-9 \mathrm{~cm}$. long; leaves lanceolate or oblong-lanceolate, with prominent midrib, $4-15 \mathrm{~cm}$. in length and about $1-1 \frac{1}{2} \mathrm{~cm}$. wide. Stem-bracts appressed, acute, usually 3 . Flowers $3-8$, sessile, reversed, with large conspicuous yellowish-brown labellum and narrow lighter-colored perianth-segments. Sepals sub-equal, subulate, about $2 \mathrm{~cm}$. long. Petals narrower and much shorter, about $13 \mathrm{~mm}$. long. Labèllum oblong or oblong-ovate, spreading, about $2 \frac{1}{2} \mathrm{~cm}$. Iong (extended) and $1 \mathrm{~cm}$. in widest part; margins somewhat sinuous towards the base, depressed about the 
middle, channelled around the tip ; lamina concave in the vicinity of the anther, elsewhere convex, traversed in its anterior-half by 2 principal somewhat beaded central raised lines and 2 secondary parallel ones all terminating in a conspicuous reddish-brown bilobed glandular process near the apex (figs. 1,3, ap.), posteriorly a central reddishbrown "guide-line" (not raised) ending below the rostellum with 2 shorter and similar lines on either side of it. Column produced laterally and posteriorly into membranous glandular toothed or fimbriate wings over the back of the anther.

Mount Compass; Myponga ; also all the Eastern States and Tasmania: Dec-Jan.

\section{PTEROSTYLIS, R. Br.}

(Greek pteron, a wing ; stylos, column.)

Dorsal sepal concave, incurved, its lateral margins dovetailed into the petals so as to form a hood or galea (Pl. 9, ii., fig. 11., $h$ ) over the column. Lateral sepals more or less united into a lower lip (ii., fig. 11, l.l.); the latter recurved, erect in front of the galea or reflexed against the ovary, adnate to the foot of the column, the ends frequently tapering into long fine points. The labellum attached by a movable, often irritable claw or hinge, to the projecting foot of the column (fig. 11., l.); ovate, oblong, linear, lanceolate or filiform; sometimes furnished with long hairs; commonly bearing at its base an appendage (figs. 6, 7, ap.) short and obtuse or linear, semicircularly eurved and penicillate. Column elongated, following the curve of the galea, its dorsum more or less adnate to the latter ; its upper part with hatchet-shaped wings (figs. $8,9, w$.) on either side of the rostellum; sometimes narrowly winged below; its base produced into a horizontal foot. Anther 2-celled, inclined over the rostellum, with a movable attachment to the back of the clinandrium, pointless. Pollinia 4, a pair in each cell, powdery, elongated, free. Stigma bilobed (figs. 8, 9, st.), prominent, situated at or near the middle of the column, usually ovate or elliptical. Rostellum (figs. 8, 10, r.) much higher up on the anterior margin of the clinandrium, just below the pollinia but unconnected with them, its borders involute so as to form a split tube communicating with the apex of stigma. Caudicle and viscid disk absent.-Terrestrial herbs with small rounded naked underground tubers. Leaves frequently in a radical rosette and more or less ovate, but often cauline and linear or lanceolate, occasionally crowded at the base and passing into stem-leaves or bracts, very rarely reduced to bracts at the time of flowering and developing at a later stage as rosettes or tufts; the non-flowering plants of all species probably represented by one of the latter. Flowers usually green, sometimes with rufous tints, commonly solitary but sometimes several in a raceme. Popularly called Green-hoods.

Of the 55 known species no less than 43 are inhabitants of Australia. Of these latter 3 extend to New Caledonia and 4 to New Zealand, the rest being endemic. The Dominion has 8 endemic species of its own and New Caledonia 2 ; 2 more are repor ed from New Guinea.

\section{SECTION 1}

Lower lip erect; the lobes or their points embracing the galea; flowers solitary, very rarely multiple.

Leaves in a radical rosette at base of scape; more or less ovate ; no stem-leaves, except sheathing bracts ; flower solitary.

Labellum bifid at tip; galea less than $2 \mathrm{~cm}$. long..... P. concinna 1 .

Labellum entire at the tip.

Points of sepals short, not exceeding galea.

Flower erect; labellum twisted, hardly recurved ; galea more than $2 \frac{1}{2} \mathrm{~cm}$. long $\ldots \ldots \ldots \ldots \ldots$

Flower nodding; labellum not twisted, much recurved; galea not exceeding $2 \mathrm{~cm} . . . . . . .$. .

Points of sepals long and fine, much exceeding galea ; galea less than $2 \mathrm{~cm}$. long.

Lobes of lower lip separated by broad sinus, with inflexed tooth between them ..............

Lobes of lower lip separated by acute sinus, without inflexed tooth.

Labellum linear-oblong, tip very blunt; stembracts very large, conspicuous, leaf-like......

Labellum ovate; stem-bracts inconspicuous, narrow, closely sheathing ...............

Leaves crowded at base of scape, passing gradually into stem-leaves or bracts. Galea at least $3 \mathrm{~cm}$. long.

Lobes of lower lip with very short points not exceeding galea ; tip of galea very short, abruptly decurved (in tiving plant) ; leaves sessile or almost so .........

P. curta 2.

P. nutans 3 .

P. nana 4.

P. Vereenae 5.

P. pedunculata 6 .

P. cucullata 7 . 
Lobes of lower lip with long points, exceeding galea ; tip of galea elongate, acute, slightly inflexed or

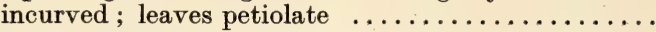

Leaves at lower part of scape reduced to scales or small bracts, gradually increasing in size to larger linear or lanceolate bracts or leaves from below upwards; lobes of lower lip produced into long fine points.

Labellum acute, lanceolate ; galea $3 \mathrm{~cm}$. or more long ; upper leaves fairly well developed, lanceolate......

Labellum acute, linear-lanceolate; galea greyish with dark striae, less than $2 \frac{1}{2} \mathrm{~cm}$. long; upper leaves

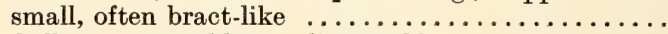

Labellum very blunt, linear-oblong; galea from $2-2 \frac{1}{2} \mathrm{~cm}$. long; upper leaves small, often bract-like..

Radical leaves not developed during flowering stage, or sometimes represented by a small lateral tuft at base of scape; no stem-leaves except a few small bracts; flowers usually 2 or more, rarely 1, small ; galea less than $10 \mathrm{~mm}$. long; sepal points very short.........

\section{P. furcata 8 .}

\section{P. reflexa 9 .}

P. alata 10.

P. obtusa 11 .

\section{Section 2.}

Lower lip reflexed against the ovary spreading or recurved ; its lobes acuminate, or prolonged into fine or linear points, or hardly acute and not produced.

Flower always solitary, large, galea about $3 \mathrm{~cm}$. long ;

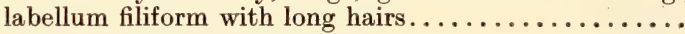

Flowers multiple, small, spicate; galea about 7 or $8 \mathrm{~mm}$. long ; sepals rather blunt, not produced ; appendage conspicuous, nearly as long as labellum; leaves in a basal rosette.

Plant very slender; basal appendage of labellum bent

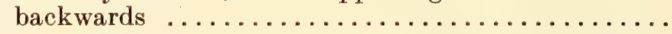

Plant rather stout; basal appendage of labellum bent

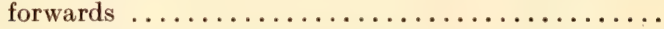

Flowers generally multiple and usually fairly large, rarely quite small; appendage of labellum almost obsolete ; lateral sepals acuminate or prolonged into fine points (caudae).

Leaves in a basal rosette.

Flowers 1.4, quite small, galea 7 or $8 \mathrm{~mm}$. long; lateral sepals acuminate, not caudate; labellum fleshy, tip straight; leaves green............

Flowers rather large, galea $10-15 \mathrm{~mm}$. long; sepals caudate.

Labellum membranous, tip upturned; stem-bracts

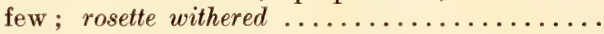

Labellum fleshy, tip upturned; stem-bracts

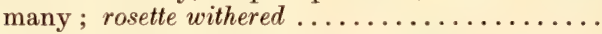

Labellum fleshy, tip depressed; stem-bracts few ;

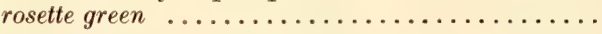

Leaves cauline, lanceolate, without basal rosette; lateral sepals with short acute tips.

Flowers green, slightly inclined away from floral axis ; lower lip narrow ; column slightly incurved, wings almost square; stigma long and narrow....

Flowers green with many dark rufous markings, nodding; lower lip very wide ; column extremely incurved, wings with oblong lower lobe ; stigma widely ovate-cordate $\ldots \ldots \ldots \ldots \ldots \ldots \ldots \ldots$

\section{P. barbata 13.}

P. mutica 14.

P. cycnocephala 15.

P. pusilla 16.

P. rufa 17.

P. squamata 18

P. Mitchellii 19.

\section{P. longifolia 20.}

P. vittata 21 .

1. P. concinna (neat), R. Br. Slender, glabrous, $4-15 \mathrm{~cm}$. high. Leaves in a basal rosette, on fairly long petioles; lamina ovate or oblong-ovate, about $1 \frac{1}{2}-2 \frac{1}{2} \mathrm{~cm}$. long. Flower solitary, green with brown points sinus and labellum. Galea light-green with darker longitudinal stripes, about $15 \mathrm{~mm}$. long, at first erect, then curved horizontally forward, its tip acute, depressed. Lower lip erect, its lobes including a very wide sinus and produced into erect fine points about $15 \mathrm{~mm}$. long on each side of galea. Labellum on a linear claw attached to the projecting foot of the column, oblong, acutely emarginate, about $8 \mathrm{~mm}$. long (including claw); penicillate appendage slender, curved forward, the 
tip multipartite; lamina almost straight, with a rather broad longitudinal raised line down the centre. Column erect, about $10 \mathrm{~mm}$. long, the upper angles of the wings very acute and higher than the anther, lower lobes broad rounded with ciliated margins. Stigma tumid, oval.

Bugle Ranges; also all Eastern States, including Tasmania. June-Aug.

2. P. curta (shortened, referring to the tips of lateral sepals), R. Br. Slender, glabrous, $10-20 \mathrm{~cm}$. high. Leaves on rather long petioles, in a radical rosette, 3-6 cm. long, lamina elliptical to oblong-elliptical. Stem-bracts usually 2, loosely sheathing; also a very loose bract subtending the flower-pedicel. Flower solitary, green, with rusty-colored labellum. Galea $3-3 \frac{1}{2} \mathrm{~cm}$. long, erect, acute but not acuminate. Lower lip with a wide sinus, the lobes shortly acuminate, not as long as the galea. Labellum on a movable claw attached to the projecting foot of the column, about $14 \mathrm{~mm}$. long (without the claw), entire, somewhat oblong-linear but twisted and wider towards the tip, only slightly recurved, the tip blunt and showing through the sinus; lamina traversed throughout by a raised longitudinal line ; appendage linear, curved, multifimbriate. Column vertical, about $20 \mathrm{~mm}$. long, adnate posteriorly to the dorsal sepal ; wings prolonged at the upper angles into fine linear points, the lower lobe oblong with ciliate internal margins. Anther horizontal or almost so, quite blunt. Stigma elliptical or ovate-elliptical, situated in the middle of the column, not viscid. Rostellum very viscid.

N.P. and other parts of Mount Lofty Range; Para Para ; Barossa ; Millicent ; also all Eastern States including Tasmania. Aug-Oct.

3. P. nutans (nodding), R. Br. Slender, glabrous, $7-20 \mathrm{~cm}$. high. Leaves rosulate on rather long petioles; lamina oblong-lanceolate to ovate, $1 \frac{1}{2}-2 \frac{1}{2} \mathrm{~cm}$. long. Stem-bracts loosely sheathing, usually 3 , in addition to that subtending the floral pedicel. Flower solitary, green, deflexed or nodding. Galea $12.14 \mathrm{~mm}$. long; erect at base but abruptly curved downwards towards the apex; terminating in an acute point or frequently with the tip of the dorsal sepal recurved, exposing the tips of the petals. Lower lip erect, the lobes with short acuminate points embacing the tip of the galea. Labellum projecting through the sinus of the lower lip, on a movable claw attached to the foot of the column, about $15 \mathrm{~mm}$. long (including claw), oblong-linear, semicircularly recurved, with blunt tip; lamina pubescent, green, with a rather broad raised brown central line extending to the tip; appendage linear curved, penicillate. Column very much incurved, about $15 \mathrm{~mm}$. long; upper angles of wings rounded, with a linear tooth; lower lobes of wings bluntly oblong-falcate, the anterior margins inturned and ciliate. Anther incumbent, very blunt. Stigma very long and narrow, pointed at both ends, not viscid. Rostellum very viscid.

Mount Barker; Cherry Gardens ; Dingabledinga; Delamere ; Millicent ; Hundred of Goyder; Kangaroo Island; also all Eastern States, including Tasmania. Sept.-Oct.

4. P. nana (dwarf), R. Br. (Pl. 9, ii.; figs. 6-11.) A rather diminutive species, usually $5-10 \mathrm{~cm}$. high. Leaves rosulate at the base of stem, petiolate; lamina ovate, elliptical or oblong-elliptical. 10-15 mm. long. Stem-bracts usually loose, acute, sheathing; a similar bract subtending the floral pedicel. Flower solitary, green, Galea erect, 12-15 mm. long, broad and obtuse at the apex. Lower lip erect; lobes separated by a broad truncate sinus with an inflexed central tooth (fig. 11, t.). produced into long erect linear points embracing the galea and much exceeding it. Labellum oblong, with a very blunt and slightly recurved tip, attached to a short linear movable claw; lamina 4-5 $\mathrm{mm}$. long, traversed by a central longitudinal ridge (fig. 6), bearing at its base a curved linear appendage with a trifid tip. Column erect, about $8 \mathrm{~mm}$. long, adnate posteriorly at the base to the dorsal sepal; the wings (figs. $8,9, w$ ) with an acute upper angle, the lower lobe oblong, obtuse with inturned hairs. Rostellum (fig. 10,r.) forming a viscid cushion in front of the clinandrium between the 2 pairs of pollinia. Stigma elliptical, not glutinous.

N.P. Distributed widely in this and all the other States but Queensland. July-Oct.

5. P. Vereenae (after Miss V. Jacob, its discoverer), Rogers. Rather slender, glabrous, $10-15 \mathrm{~cm}$. high. Leaves rosulate at the base, usually sessile but sometimes shortly petiolate, ovate-lanceolate or elliptical; a very large leaf-like bract near the base of stem and a similar one subtending the floral pedicel, both broadly lanceolate and sheathing at their bases. Flower green, solitary, Galea about $2 \mathrm{~cm}$. long, erect, abruptly curved forwards towards the end. terminating in rather an acute depressed point. Lower lip enclosing an acute sinus without an inflexed tooth; its lobes produced into fine points embracing the galea and exceeding the latter in length. Labellum on a movable claw, linear-oblong, with a very blunt and moderately recurved tip protruding from the sinus; lamina about $10 \mathrm{~mm}$. long, traversed throughout by a broad raised central longitudinal line; the basal appendage curved, linear, trifid at the end. Column about $12 \mathrm{~mm}$. long erect; upper angle of the wings produced into an acute tooth, lower angle into a ciliate blunt linear-oblong lobe. Stigma rather widely elliptical, tumid.

Cherry Gardens. Sept: 
6. P. pedunculata (stalked), R. Br. Very slender, 10-22 cm. high. Leaves basal, rosulate, ovate or oblong, on long petioles, lamina $1 \frac{1}{2}-2 \frac{1}{2} \mathrm{~cm}$. long. Stem-bracts small, usually 2 or 3 besides that subtending the floral pedicel. Flower solitary, green, with dark-brown coloration about the sinus of the lower lip and apex of the galea. Galea about $13 \mathrm{~mm}$. long, erect, then curved horizontally forward to the tip, terminating in a short acute point. Lower lip erect, the lateral lobes enclosing a rather acute sinus without an inflexed tooth, produced into long slender diverging subulate points on each side of the galea and exceeding the latter. Labellum dark-brown, bluntly ovate, on a movable claw. shorter than the column; lamina about $5 \frac{1}{3} \mathrm{~mm}$. lo $\mathrm{ng}$, traversed by a raised central line ; basal appendage rather long, linear, curved, trifid at the end. Column erect, about $11 \mathrm{~mm}$. long; upper angle of wings produced into a filiform process ; lower lobe lanceolate with obtuse point and inturned ciliated margin. Stigma elliptical, not viscid.

N.P. and other parts of Mount Lofty Range ; Beetaloo ; Millicent ; also New South Wales; Victoria; Tasmania. Aug.-Oct.

7. P. cucullata (hooded), R. Br. Stout, glabrous, often dwarfed, $5-25 \mathrm{~cm}$. high. Leaves crowded at base of scape, sessile or almost so ; oblong, elliptical or obovate, often 7-9 $\mathrm{cm}$. long: passing intu 2 or 3 large leaf-like bracts, the uppermost one subtending the floral pedicel, and usually including the ovary and sometimes part of the perianth. Flower large, solitary, glandular-pubescent, the dorsal sepal generally green, the petals labellum and lower lip chocolate. Galea upwards of $3 \mathrm{~cm}$. long; the tip abruptly decurved in the living plant, very short and acute. Lower lip erect; the lobes including an acute sinus, shortly acuminate, curved backwards against the sides of the galea but not exceeding the latter. Labellum oblong-elliptical or narrow-elliptical; the tip very blunt, slightly recurved, on a linear movable claw ; lamina about $14 \mathrm{~mm}$. long, traversed throughout by a central raised line; basal appendage curved, linear, densely penicillate. Column erect. about $22 \mathrm{~mm}$. long; upper margin of wings rounded with a short acute tooth; lower lobe somewhat oblong with blunt tip. Stigma broad, short, ovate-lanceolate or elliptical.

N.P. and Mount Lofty Range; Cherry Gardens; McLaren Vale; Millicent; also New South Wales; Victoria; Tasmania. Sept.-Oct.

8. P. furcata (forked, referring to the points of the lateral sepals), Lindl. A very slender glabrous species, $\mathbf{1 5 - 2 5} \mathrm{cm}$. high. Leaves $3-5$, on rather long petioles inserted at or near the base, gradually passing into large leaf-like stem-bracts; lamina oblong-lanceolate or elliptical, $2.4 \mathrm{~cm}$. long: stem-bracts usually 2 or 3 (including the one subtending the floral pedicel), loosely sheathing, from $2 \frac{1}{2} 4 \mathrm{~cm}$. long. Flower large, solitary, Galea erect, rather narrow, about $4 \mathrm{~cm}$. long from apex to base; tip very acuminate, inclined upwards and slightly forwards. Lower lip markedly cuneate; lobes including a rather narrow sinus of $70^{\circ}-80^{\circ}$, tips produced into long ine points embracing the galea and exceeding it. Labellum on a movable claw, oblong-linear with a very blunt slightly recurved tip, rather wider at the base ; lamina about $16 \mathrm{~mm}$. long, a central raised line prominent throughout its length, the margins upturned, transverse section showing a double crescent, thus — - ; basal appendage linear, curved, unusually long, densely penicillate. Column erect, much shorter than the labellum, about $17 \mathrm{~mm}$. long: the upper angle of the wings with a short subulate process, the lower lobe blunt linear-oblong ciliate. Stigma rather narrow, oblong-lanceolate.

Mount Gambier ; Kangaroo Island; also Victoria and Tasmania. Dec.-Jan.

9. P. reflexa (bent back), R. Br. Slender, glabrous, from $5-20 \mathrm{~cm}$. high. Leaves cauline at time of flowering, those at lower part of scape reduced to small bracts, gradually increasing in size from below upwards, lanceolate or acuminate, clasping at the base, the longer ones often attaining a length of 4 or $5 \mathrm{~cm}$. Flower green, large, solitary. Galea about $3 \cdot 2 \mathrm{~cm}$. with the point, gradually incurved, the apex produced into a short but fine point (about $4 \mathrm{~mm}$. long). Lower lip erect; the lobes separated by a wide sinus, produced into long filiform points embracing the galea and greatly exceeding it. Labellum on a movable claw, nearly straight, lanceolate, tapering to an acute point, when erect slightly exceeding the column; the lamina about $15 \mathrm{~mm}$. long, traversed by a central raised line; basal appendage linear, much curved, penicillate. Column erect, about $16 \mathrm{~mm}$. long; upper angle of wings acute, lower lobe oblong, blunt with inturned ciliated margins. Stigma elliptical.

N.P. Widely distributed south of Orroroo and reported as far west as Yeelanna ; also from all other States. May-Aug.

10. P. alata (winyza $)$, Reich.f. A more slender plant than the preceding, with smaller flowers and more bract-like leaves. Rarely exceeding $15 \mathrm{~cm}$. high. No rosulate !eaves at time of flowering; stem-leaves usually quite small and bract-like, 3 or 4 . including the one subtending the floral pedicel. Flower solitary, greyish with reddish-brown striae. Gialea erect or gradually incurved; the apex rather blunt, ending in a very short fine point (about $2 \mathrm{~mm}$.), $22 \mathrm{~mm}$. long including the point. Lower lip erect; lobes separated by a very wide truncate sinus with a notch in the middle, the tips produced into long filiform points embracing the galea and much exceeding it. Labellum reddish-brown 
on a movable claw, almost straight, very narrow-lanceolate, tapering to an acute point, slightly exceeding the column when erect; the lamina about $10 \mathrm{~mm}$. long, traversed by a central raised line; basal appendage narrow-linear, curved, penicillate. Column erect about $11 \mathrm{~mm}$. long; upper angle of wings falcate, lower lobe oblong, blunt, with inturned ciliated margins. Stigma prominent, bilobed, elliptical.-P. praecox, Lindl.

Victor Harbor; Kangaroo Island; also New South Wales; Victoria; Tasmania. May-July.

11. P. obtusa (obtuse, referring to the labellum), R. Br. Very slender, glabrous, 12-25 $\mathrm{cm}$. high. No rosette at the time of flowering. Stem-leaves usually small and bractlike, $3-5$, including the one subtending the floral pedicel, lanceolate, clasping at the base, the upper ones longer than those below. Flower solitary, green. Galea (including the point) $2-2 \frac{1}{2} \mathrm{~cm}$. long, at first erect, then gradually incurved, the apex ending in a fine point about $5 \mathrm{~mm}$. long. Lower lip erect, cuneate; lobes separated by a broad sinus with a notch in the middle, produced into long fine points embracing the galea and much exceeding it. Labellum slightly exceeding the column, reddish-brown, oblong-linear, tip very obtuse and slightly recurved; lamina about $9 \mathrm{~mm}$. long, with a raised longitudinal line down the centre; appendage linear, curved, penicillate. Column erect, about $10 \mathrm{~mm}$. long; upper angle of wings produced into an acute tooth, lower lobe blunt oblong. Stigma lanceolate, tumid.

District of Victor Harbor; Clinton; Millicent; Kangaroo Island; also all the Eastern States and Tasmania. April-May.

12. P. parviflora (small-flowered), R. Br. A small, slender species, $5-15 \mathrm{~cm}$. high. Radical leaves not developed during the flowering stage or sometimes represented by a small lateral tuft at base of scape ; no stem-leaves except several small acute bracts. Flowers 1-5, very small, green, racemose. Galea much incurved; apex rather blunt in the living plant, not produced into a fine point; about $8 \mathrm{~mm}$. long. Lower lip cuneate, erect; lobes including a very wide sinus with a notch in the middle, shortly acuminate, embracing the galea but always shorter than it. Labellum oblong or linear-oblong, on a movable claw ; the tip slightly recurved, obtuse ; lamina about $2 \frac{3}{4} \mathrm{~mm}$. long, traversed by a broad red raised central line with a narrow red line on either side of it; basal appendage linear, curved, 3-partite. Column about $5 \mathrm{~mm}$. long, erect, slightly longer than the labellum; upper angle of wings produced into an acute tooth, the lower lobe oblong ciliate. Stigma relatively large and prominent, cordate.

Myponga; Mount Compass; also in all the Eastern States, including Tasmania. April-May.

13. P. barbata (bearded, referring to the labellum), Lindl. Moderately robust, 12-30 $\mathrm{cm}$. high. Leaves sessile, generally numerous, crowded at or near the base, lanceolate or oblong-lanceolate, $1 \frac{1}{2}-5 \mathrm{~cm}$. long, often extending half-way up the stem, sometimes fewer and more distant, passing into acute sheathing bracts often imbricate. Flower green, solitary. Galea erect, somewhat oblong, about $3 \mathrm{~cm}$. from base to crest, ending in a rather short subulate point, inflated in its lower half, the margins pinched laterally about the middle. Lower lip linear, reflexed or recurved in mature flower, the lobes almost parallel, linear, acute, about $3 \mathrm{~cm}$. long. Labellum about $2 \mathrm{~cm}$. long, on a narrow-oblong irritable claw, filiform except at the extremities, narrowly channelled below ; base dilated into an elongated somewhat boat-shaped process, glabrous and transversely corrugated above, ciliate on the margins and produced posteriorly beyond the insertion of the claw ; tip brown carunculate with 2 small oblong depressed wings; filiform portion with long oblique yellow hairs. Column erect, about $2 \mathrm{~cm}$. long; rather broadly winged; upper border of wings rounded with a prominent straight narrow-linear process, lower lobes blunt falcate-oblong ; anterior borders inturned and ciliate. Stigma considerably wider than the column, bilobed, narrowly obovate, not viscid until after pollination.

N.P. and other parts of Mount Lofty Range ; Beetaloo ; Goolwa ; Nangkita ; Milli cent; Yeelanna, Ungarra, and other parts of Eyre Peninsula; Kangaroo Island; also all States except Queensland. Sept.-Oct.

14. P. mutica (docked, referring to the blunt lateral sepals), R. Br. A small, slender, glabrous species, usually $7-10 \mathrm{~cm}$. high. Leaves 4 or 5 , in a radical rosette, ovate to elliptical, on very short petioles; lamina $15-20 \mathrm{~mm}$. long; stem-bracts acute, empty, sheathing, usually 2 in addition to those subtending the pedicels. Flowers green, $2-8$, in a slightly spiral spike. Galea nearly $7 \mathrm{~mm}$. long, incurved, broad, blunt ; lower lip reflexed or spreading, shorter than galea, the lobes short, broad, hardly acute. Labellum attached by a wide and moderately long claw $(1 \mathrm{~mm}$.) to the foot of column, quadrate, tip broadly rounded and slightly emarginate; lamina about $2 \mathrm{~mm}$. long, traversed by a raised central line; appendage large (about $1 \frac{1}{1} \mathrm{~mm}$. long), oblong, fleshy, the tip turned back. wards. Column about $6 \mathrm{~mm}$. long, reaching almost to top of galea : wings quite rounded, anterior margin ciliate, almost semicircular, without any tooth, the lower lobe bluntly triangular ciliate. Stigma narrow-elliptical.

As far north as Mount Patawurta (Flinders Range) and west to Fowler's Bay ; south to Mount Gambier; also all eastern States and Tasmania. July.Sept. 
15. P. eycnocephala (swan-headed, referring to the appendage of the labellum), Fitzg. Rather stout, $3-15 \mathrm{~cm}$. high. Leaves 7-9, petiolate, in a crowded basal rosette, ovalelliptical; lamina $10-15 \mathrm{~mm}$. long; stem-bracts generally 1 or 2 , leafy, near the base, also a loose one subtending each pedicel. Flowers small, green, 2-6 in a raceme (often spiral), usually crowded. Galea incurved, blunt, broad, a little more than $7 \mathrm{~mm}$. long. Lower lip shorter than the galea, reflexed; lobes only separated at the extreme tips, latter hardly acute. Labellum on a short broad claw (about $1 \mathrm{~mm}$ ), quadrate, iip broadly rounded and slightly emarginate ; lamina about $2 \mathrm{~mm}$. long, traversed by a central raised line; appendage highly irritable, as wide a the base as the labellum, flat and narrowing towards its apex, ending in a dark green conical process looking towards the tip of labellum. Column nearly $7 \mathrm{~mm}$. long, not quite reaching top of galea; wings quite rounded, the anterior margin almost semicircular, ciliate without any tooth, lower lobe broad triangular blunt ciliate. Stigma ovate-lanceolate.

Monarto South; Cherry Gardens ; also New South Wales ; Victoria; Tasmania. Sept.

16. P. pusilla (small), Rogers. A slender rather diminutive species, 6-9 cm. high, Leaves in a green radical rosette, shortly petiolate ; lamina about $13 \mathrm{~mm}$. long, oblonglanceolate; stem-bracts 2, closely sheathing, and one subtending each floral pedicel. Flowers 1-4, racemose, on slender pedicels, green, with reddish tints on lower lip labellum and margins of galea. Galea about $8 \mathrm{~mm}$. or less long from base to crest, with short subulate point. Lower lip recurved or reflexed, concave, margins involute, about same length as galea; lobes shortly acuminate. Labellum oblong fleshy and very irritable on a long wide claw, concave on its upper surface, tip straight, very blunt and rounded, posterior margin thickened; under surface with a deep central channel running from base to tip betweer. 2 pear-shaped swellings, the apices of which are directed forwards; lateral margins with a few long hairs, posterior margins and tip shortly ciliate, channel on lower surface beset with stiff transverse hairs ; lamina about $2 \frac{1}{4} \mathrm{~mm}$. long ; appendage almost obsolete, represented by the thickened posterior margin. Column incurved, about $5 \frac{3}{4} \mathrm{~mm}$. long; wings wide, roughly quadrangular with upper and lower angles rounded and ciliate, no tooth present, anterior margins with inturned ciliate edges. Stigma obovate, membranously expanded, wider than the column.

Geranium; Wirrega ; also Victoria. Early October.

17. P. rufa (reddish), R. Br. Moderately robust, usually $10-25 \mathrm{~cm}$. high. Leaves in a withered basal rosette at the time of flowering, shortly petiolate; lamina $1-2 \mathrm{~cm}$. long, moderately acute and usually ovate or oblong; stem-bracts 2-5, acute, scarious, loosely sheathing, besides those subtending the pedicels. Flowers rather large, usually $2-4$, rarely 1 , on long slender pedicels in a raceme, green with rufous markings. Galea from base to crest about $13 \mathrm{~mm}$., broad, incurved, the apex produced into a fine point usually 10-15 mm. long. Lower lip recurved or reflexed; about as long as the galea ; the lobes elliptical, produced into fine points or caudae of varying length, commonly about $2 \mathrm{~cm}$. Labellum attached by rather a long claw to the foot of column, membranous, rather narrow-oblong, the tip entire, blunt and turned upwards; the lamina about $6 \mathrm{~mm}$. long, the posterior margin thickened and forming a transverse ridge in front of the claw, traversed by a central longitudinal ridge; deeply channelled below; generally 2 long setae on the base, the lateral margins and tip sparsely ciliate ; appendage almost obsolete, represented by thickened posterior margin. Column incurved, nearly $13 \mathrm{~mm}$. long, reaching to top of galea ; wings almost square, upper angle acute ciliate, anterior margins inturned ciliate, lower lobe rather blunt ciliate. Stigma narrow-elliptical.

N.P. Widely distributed as far north as Moolooloo (Flinders Range); also in all the other States. Nov.-Dec.

18. P. squamata (scaly, referring to stem-bracts), R. Br. Stout, glabrous, about $15 \mathrm{~cm}$. high. Leaves in a withered basal rosette at time of flowering, similar to those of P. rufa; stem-bracts 6-8, acute, sheathing closely appressed, in addition to those at the base of the pedicels, the lower ones partially imbricate, the distance between them increasing in the upper part of the stem but always short. Flowers greenish with rufous markings, 2 or 3, on rather long pedicels. Galea from base to crest about $10 \mathrm{~mm}$. long, the apex produced into a fine point about $6 \mathrm{~mm}$. long, Lower lip reflexed, about as long as the galea, the lobes produced into fine points about $10 \mathrm{~mm}$. long. Labellum thick and fleshy, conspicuously glandular, very irritable, on a wide movable claw, tip straigh bifid, contracted towards the base; lamina about $5 \mathrm{~mm}$. long, hollowed out to within a short distance of the tip, a low wide rounded or somewhat triangular eminence at the base with a long bristle on each side ; lateral margins sparsely ciliate with long hairs ; undersurface deeply and narrowly channelled; appendage almost obsolete, represented by the basal eminence. Column incurved, reaching to top of galea; wings almost quadrangular, upper angles blunt not toothed or ciliate, lower lobes blunt and ciliate, anterior margin with inturned hairs or fringe. Stigma oblong-elliptical.

Enfield; Port Lincoln ; also Tasmania. Nov.

19. P. Mitchellii (after Sir Thomas Mitchell, explorer), Lindl. Rather slender, $7-15 \mathrm{~cm}$. high. Leaves in a green basal rosette, very shortly petiolate, not very acute; lamina 20-30 mm. long, elliptical; stem-bracts 2-4, closely sheathing and one subtending each 
floral pedicel. Flowers 3-6, in a loose raceme, rather large, greenish with reddish tints on lower lip and margins of galea. Galea from base to crest about $12 \mathrm{~mm}$. long, the apex produced into a fine recurved point, $8-10 \mathrm{~mm}$. long. Lower lip reflexed, the lobes ovate, including an acute sinus, prolonged into fine diverging tails $15-17 \mathrm{~mm}$. long. Labellum thick and fleshy, glandular on a movable semicircular claw, very irritable, slipper-shaped, tip slightly cleft below and turning a little downwards, contracted near the base; lamina about $3 \frac{1}{2} \mathrm{~mm}$. long, the basal margin thickened and slightly raised, usually without hairs, in front of this hollowed out for the greater part of its length; under-surface deeply channelled from base to tip; lateral margins ciliate; appendage almost obsolete, represented by the raised basal margin. Column about $9 \mathrm{~mm}$. long, incurved, reaching nearly to the top of the galea; wings quadrangular, upper angle rather acute and ciliate, the lower one quite blunt and ciliate, anterior margins with inturned hairs. Stigma semi-elliptical, upper margin notched or toothed.

The Grange. Ranging from Mount Patawurta (Flinders Range) to Millicent, near Mount Gambier; also all Eastern States, not including Tasmania. Aug.-Sept.

20. P. longifolia (long-leaved), R. Br. Rather rigid, $10-30 \mathrm{~cm}$. high. Basal rosette not present at the time of flowering; stem-leaves reduced to small scales near the base, acute, clasping, narrow-lanceolate, $1-4 \mathrm{~cm}$. long above the middle ; very rarely a lateral basal tuft present in addition to the stem-leaves. Flowers usually 3-8, in a raceme, rarely 1, green, an acute bract subtending each pedicel. Galea about $15 \mathrm{~mm}$. or less from base to crest, gradually incurved, apex acute but not prolonged into a fine point. Lower lip reflexed in the mature flower, rather narrow, the lobes with short acuminate tips. Labellum on a short movable claw, very irritable, oblong, slightly 3-lobed towards the end; the lateral lobes very small; the tip or middle lobe upturned, bifid; lamina about $8 \mathrm{~mm}$ long, papillose-glandular, convex and much thickened at the base with a short pyramidal appendage, thereafter concave; channelled below. Column incurved, reaching to top of galea; wings nearly square, upper margin crescentic with a short rather blunt tooth about the middle, upper angle blunt and rounded, front margins with inturned hairs. Stigma lanceolate.

N.P. and other parts of Mount Lofty Range; Clinton; Bordertown; Millicent ; Yeelanna; Kangaroo Island; all Eastern States and Tasmania. June-July.

21. P. vittata (banded, referring to the stripes on the galea), Lindl. Similar in habit to $P$. longifolia, but with rather wider leaves. Flowers nodding, greenish with many red tints and stripes, sometimes solitary, more frequently several in a compact terminal raceme. Galea broad, about $14 \mathrm{~mm}$. long from base to crest, its aperture directed downwards, the apex ending in a very short acute point, greenish with dark-green or dark-red longitudinal stripes, the petals more or less completely red. Lower lip reddish, reflexed or recurved, very wide, usually ovate-orbicular, about $14 \mathrm{~mm}$. long and $11 \mathrm{~mm}$. wide, the lobes with short acute points. Labellum on a rather long and vary irritable claw, broadly oblong, contracting somewhat abruptly to a blunt point ; tip bifid and upturned; margins otherwise entire; lamina about $5 \mathrm{~mm}$. long, glandular, margins hairy, the base much thickened and raised into an eminence furnished with a free hairy linear process directed forwards and upwards, the upper surface thereafter concave with a broad raised line down the centre; lower surface longitudinally channelled. Column reaching to crest of galea, greatly incurved; wings with a small blunt tooth at upper angle, lower lobe narrow elongate almost acute ciliate, front margins with long inturned hairs. Stigma membranous, obovate, not prominent, much expanded laterally, exceeding the column in breadth.

N.P. and other parts of Mount Lofty Range; Beetaloo ; Halbury ; Yeelanna ; Ungarra; Goolwa; Millicent; Kangaroo Island; also Victoria ; Tasmania ; and Western Australia. May-July. 


$$
\text { - }
$$

.

- 


SMITHSONIAN INSTITUTION LIBRARIES

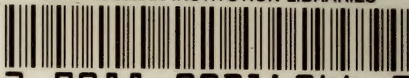

39088 00376044?

nhbohc QK 455.862

pt. 1 Flora of South Australia. 